VILNIAUS GEDIMINO TECHNIKOS UNIVERSITETAS

Aušra KATINIENE

\title{
ORGANIZACIJOS DARBUOTOJŲ ŽINIŲ SINERGIJOS VERTINIMAS
}

DAKTARO DISERTACIJA

SOCIALINIAI MOKSLAI, VADYBA (03S)

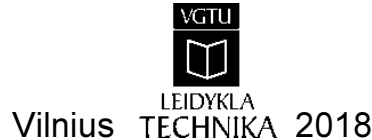


Disertacija rengta 2013-2018 metais Vilniaus Gedimino technikos universitete.

Vadovas

doc. dr. Ilona SKAČKAUSKIENE (Vilniaus Gedimino technikos universitetas, vadyba - 03S).

Vilniaus Gedimino technikos universiteto Vadybos mokslo krypties disertacijos gynimo taryba:

\section{Pirmininkas}

prof. habil. dr. Romualdas GINEVIČIUS (Vilniaus Gedimino technikos universitetas, vadyba - 03S).

\section{Nariai:}

prof. dr. Zenona Ona ATKOČIŪNIENE (Vilniaus universitetas, komunikacija ir informacija-08S),

doc. dr. Renata KORSAKIENĖ (Vilniaus Gedimino technikos universitetas, vadyba - 03S),

dr. Natalia SULIKASHVILI GUILLUY (Lilio katalikiškasis universitetas, vadyba-03S),

doc. dr. Živilè TUNČIKIENĖ (Vilniaus Gedimino technikos universitetas, vadyba - 03S).

Disertacija bus ginama viešame Vadybos mokslo krypties disertacijos gynimo tarybos posėdyje 2018 m. birželio 1 d. 13 val. Vilniaus Gedimino technikos universiteto senato posèdžių salèje.

Adresas: Sauletekio al. 11, LT-10223 Vilnius, Lietuva.

Tel.: (8 5) 274 4956; faksas (8 5) 270 0112; el. paštas doktor@vgtu.lt

Pranešimai apie numatomą ginti disertaciją išsiųsti $2018 \mathrm{~m}$. balandžio $30 \mathrm{~d}$.

Disertaciją galima peržiūrèti VGTU talpykloje http://dspace.vgtu.lt ir Vilniaus Gedimino technikos universiteto bibliotekoje (Saulètekio al. 14, LT-10223 Vilnius, Lietuva).

VGTU leidyklos TECHNIKA 2018-017-M mokslo literatūros knyga

http://leidykla.vgtu.lt

ISBN 978-609-476-105-8

(C) VGTU leidykla TECHNIKA, 2018

(C) Aušra Katinienè, 2018

ausra.katiniene@vgtu.lt 
VILNIUS GEDIMINAS TECHNICAL UNIVERSITY

Aušra KATINIENE

\section{EVALUATION OF ORGANISATION EMPLOYEE KNOWLEDGE SYNERGY}

DOCTORAL DISSERTATION

SOCIAL SCIENCES, MANAGEMENT (03S)

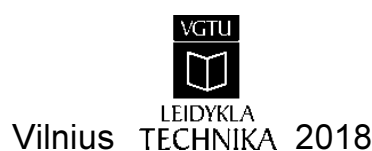


Doctoral dissertation was prepared at Vilnius Gediminas Technical University in 2013-2018.

\section{Supervisor}

Assoc. Prof. Dr Ilona SKAČKAUSKIENĖ (Vilnius Gediminas Technical University, Management - 03S).

The Dissertation Defence Council of Scientific Field of Management of Vilnius Gediminas Tehcnical University:

\section{Chairman}

Prof. Dr Habil. Romualdas GINEVIČIUS (Vilnius Gediminas Technical University, Management - 03S).

\section{Members:}

Prof. Dr Zenona Ona ATKOČIŪNIENE (Vilnius University, Communication and Information - 08S),

Assoc. Prof. Dr Renata KORSAKIENĖ (Vilnius Gediminas Technical University, Management - 03S),

Dr Natalia SULIKASHVILI GUILLUY (Lille Catholic University, Management - 03S),

Assoc. Prof. Dr Živilè TUNČIKIENE (Vilnius Gediminas Technical University, Management - 03S).

The dissertation will be defended at the public meeting of the Dissertation Defence Council of Management in the Senate Hall of Vilnius Gediminas Technical University at 1 p. m. on 1 June 2018.

Address: Saulètekio al. 11, LT-10223 Vilnius, Lithuania. Tel.: +370 5274 4956; fax +370 5270 0112; e-mail: doktor@vgtu.lt

A notification on the intend defending of the dissertation was send on 30 April 2018.

A copy of the doctoral dissertation is available for review at VGTU repository http://dspace.vgtu.lt and at the Library of Vilnius Gediminas Technical University (Sauletekio al. 14, LT-10223 Vilnius, Lithuania). 


\section{Reziumè}

Disertacijoje nagrinëjama organizacijos žinių sinergijos vertinimo, taikant sistemini požiūrị, problema. Sisteminis žinių sinergijos vertinimas svarbus organizacijoms siekiant koreguoti, keisti arba integruoti naujas žinių dalijimosi bei bendradarbiavimo skatinimo priemones, siekiant geresnių veiklos rezultatų ir taip didinant organizacijos potencialą. Tyrimu objektas - darbuotojų žinių sinergijos vertinimas organizacijoje. Darbo tikslas - sukurti organizacijos darbuotojų žinių sinergijos vertinimo metodų rinkini, kurio taikymas leistų kiekybiškai įvertinti organizacijos darbuotojų žinių sinergiją ir jos komponentus bei sudarytų prielaidas teikti pagrisstus darbuotojų žinių ir ryšių tarp darbuotojų valdymo tobulinimo siūlymus.

Disertaciją sudaro įvadas, keturi skyriai, bendrosios išvados ir dešimt priedų.

Pirmame disertacijos skyriuje išanalizuota žinių svarba ir probleminès sritys žinių visuomenejje, apžvelgta žinių sklaida, atskleistos žinių sinergijos formavimosi prielaidos, suformuluotas žinių sinergijos apibrěžimas bei pagristas šios sąvokos naudojimas, atlikta išsami mokslinių šaltinių analizè sinergijos, žinių sinergijos sampratos tema. Antrame disertacijos skyriuje išanalizuota žinių sinergijos vertinimo metodinè bazè, išgryninti žinių sinergijos komponentai, o atlikus įvairių šaltinių kritinę analizę pagrịstas žinių sinergijos vertinimo metodų rinkinio kūrimo tikslingumas. Trečiame disertacijos skyriuje aprašytas parengtas žinių sinergijos vertinimo metodų rinkinys, išskirti žinių sinergijos tipai, atsižvelgiant i ryšių susiformavimą organizacijoje. Metodų rinkinio esmé komponentai vertinami kiekybiškai taikant grafų teoriją, kombinatoriką ir daugiakriterinius vertinimo metodus. Kiekybinio organizacijos žinių sinergijos vertinimo rezultatai sudaro prielaidas išgryninti pažangius bei probleminius veiklos procesus, t. y. atlikti išsamų ir tikslų ịvertinimą, ir priimti sprendimus veikloms efektyvinti. Ketvirtame skyriuje pateikta žinių sinergijos vertinimo schema bei aprašyta žinių sinergijos vertinimo metodų rinkinio taikymo metodika. Šiame skyriuje taip pat pateikti žinių sinergijos vertinimo metodų rinkinio eksperimentinio taikymo organizacijose rezultatai, kurie pagrindžia žinių sinergijos vertinimo metodų rinkinio naudą organizacijos veiklos procesų analizei. 


\section{Abstract}

The dissertation analyses the problem of organisation knowledge synergy evaluation through a systematic approach. A systematic synergy evaluation is important for organisations if they wish to adjust, change or integrate new knowledge sharing as well as cooperation incentives in order to seek better performance results and increase their potential. The research object is the evaluation of knowledge synergy in organisations between employees. The aim of the dissertation is to develop a set of methods for organisation employee knowledge synergy evaluation, the application of which would enable quantitative evaluation of organisation employee knowledge synergy and its components, and would prepare the ground for reasonable suggestions concerning the improvement of employee knowledge as well as the management of employee links.

The dissertation consists of the introduction, four chapters, general conclusions and annexes.

The first dissertation chapter analyses the importance of knowledge and the problem areas in the knowledge society; reviews the dissemination of knowledge; reveals the preconditions for knowledge synergy formation; formulates the definition of knowledge synergy and the validity of the use of this term. Moreover, the first chapter contains a detailed analysis of scientific sources on the topic of the concept of knowledge synergy. The second chapter part analyses the methodological base of knowledge synergy evaluation; emphasizes knowledge synergy components; and validates the relevance of the development of such a set of methods for knowledge synergy evaluation on the basis of a critical analysis of various sources. The third dissertation chapter describes the prepared set of methods for knowledge synergy evaluation; singles out the types of knowledge synergy with reference to the formation of links in an organisation. The essence of the set of methods is the components that are evaluated quantitatively with the help of graph theory, combinatorics and multicriteria evaluation methods. The fourth chapter includes a principle scheme for the evaluation of knowledge synergy and describes the methods for the application of the set of methods for knowledge synergy evaluation. This chapter also presents the results of experimental application of the set of methods for knowledge synergy evaluation in organisations between employees. The results justify the benefit of the set of methods for knowledge synergy evaluation for the analysis of business processes of an organisation. 


\section{Žymèjimai}

\section{Simboliai}

$\alpha$ - išreikštinių žinių bloko reikšmingumo koeficientas;

$\beta$-neišreikštinių žinių bloko reikšmingumo koeficientas;

$\eta_{i}$ - darbuotojo darbo užmokesčio veiksnio koeficientas;

$\lambda_{j}-\mathrm{j}$-ojo veiksnio reikšmingumas;

$\widehat{D}$ - komandinis darbas;

$\ddot{G}$ - galia;

$\widehat{G}$ - individualūs gebejjimai;

$\overline{\bar{G}}$ - našumo potencialas;

$I_{S}$ - asmens sinergija;

$\overline{\bar{N}}$ - faktinis našumas;

$P_{s l}$ - organizacijos žinių potencialo sinergija;

$\ddot{S}$ - sklaida;

$\overline{\bar{T}}$ - trukdžiai;

$\widehat{V}$ - darbo pridètinè vertè;

$\tilde{a}$-atsakomybès veiksnio koeficientas;

$\tilde{f}$ - kvalifikacijos tobulinimo veiksnio koeficientas; 
$\tilde{g}$ - darbo sudetingumo veiksnio koeficientas;

$\tilde{\imath}$ - išsilavinimo veiksnio koeficientas;

$\tilde{k}$ - darbuotojo kultūros veiksnio koeficientas;

$\tilde{l}$ - pareigų lygio veiksnio koeficientas;

$\widetilde{m}$ - motyvacijos dirbti veiksnio koeficientas;

$m_{\check{z}}-$ žinių multiplikatorius;

$m_{i}$ - išreikštinių darbuotojo žinių veiksnių dedamoji;

$n_{i}$ - neišreikštinių darbuotojo žinių veiksnių dedamoji;

$\tilde{o}$ - darbuotojo ịtaka organizacijos tikslų igyvendinimui veiksnio koeficientas;

$\tilde{p}$ - profesinès patirties veiksnio koeficientas;

$p_{v}$ - vidutinis darbuotojų žiniu potencialas, tenkantis vienam ryšiui;

$r_{e}$ - efektyvių ryšių norma;

$\tilde{t}$ - technologijų naudojimo darbe veiksnio koeficientas;

$\tilde{u}$ - darbuotojo darbo užmokesčio veiksnio koeficientas;

$\tilde{v}$ - savarankiškumo darbe veiksnio koeficientas;

$\gamma_{i}$ - išreikštinių darbuotojo žinių veiksnių dedamujų reikšmingumai;

$\delta_{i}-$ neišreikštinių darbuotojo žinių veiksnių dedamujų reikšmingumai;

$A$ - atsakomybès veiksnys;

$b$ - nesutariančių asmenų komandoje skaičius;

$\mathrm{B}$ - pirmasis veiksnys;

$\mathrm{C}$ - antrasis veiksnys;

$D$ - darbuotojo žinios;

$D_{i}$ - darbuotojo žinių indeksas;

$E$ - asmens energija;

$F$ - kvalifikacijos tobulinimo veiksnys;

$f$-sutariančių asmenų komandoje skaičius;

$G$ - darbo sudètingumo veiksnys;

$h$ - ịverčių intervalo žingsnis;

$I$ - išsilavinimo veiksnys;

$i$ - rodiklio numeris;

$I_{i}$ - išreikštinių darbuotojo žinių veiksnių suma;

$j$ - ryšių tipų skaičius;

$K$ - darbuotojo kultūros veiksnys;

$k$ - intervalų skaičius;

$L$ - pareigu lygio veiksnys;

$M$ - motyvacijos dirbti veiksnys; 
$m$ - veiksnių skaičius;

$n$ - darbuotojų skaičius;

$N$ - pavaldinių skaičius;

$N_{j}$ - neišreikštiniu žinių darbuotojo veiksnys;

$O$ - darbuotojo ịtaka organizacijos tikslu ịgyvendinimui veiksnys;

$p$ - ekspertu skaičius;

$P$ - profesinès patirties veiksnys;

$P_{d}$ - darbuotojo žinių potencialas;

$R$ - ryšiai tarp darbuotojų;

$R_{f}$ - faktinis ryšių skaičius;

$R_{y}$ - ryšių skaičius;

$r_{\text {max }}$ - maksimalus ryšių tarp darbuotojų skaičius;

$r_{t}$ - teorinis ryšių tarp darbuotojų skaičius;

$r_{i}$ - rangas;

$r_{i j}$ - priskirtas rangas;

$r_{i j+1}-$ sekantis rangas eileje;

$S$ - sinergija;

$S_{\check{z}}-$ žinių sinergija;

$T$ - technologijų naudojimo darbe veiksnys;

$T_{T}$ - tinklo tankumas;

$U$ - darbuotojo darbo užmokesčio veiksnys;

$V$ - savarankiškumo darbe veiksnys;

$V_{A}$ - poaibis rodiklių, turinčių didžiausią ịtaką žinių sinergijai;

$V_{B}-$ poaibis rodiklių, turinčių vidutinę įtaką žinių sinergijai;

$V_{C}$ - poaibis rodiklių, mažiausiai veikiančių arba visai neturinčių ịtakos žinių sinergijai;

$V I$ - išreikštinių žinių įvertis;

$V I_{n}-n$-ojo darbuotojo išreikštinių žinių veiksniai;

$V_{j n}-j$-ojo veiksnio ịvertis $n$-ojo darbuotojo atžvilgiu;

$V N$ - neišreikštinių žinių ịvertis;

$V N_{n}-n$-ojo darbuotojo neišreikštinių žinių veiksniai;

$W$ - konkordacijos koeficientas;

$w_{i j}-$ normalizuotos veiksnių reikšmès;

$x_{\max }$ - didžiausias veiksnių ịvertis;

$x_{\min }$ - mažiausias veiksnių ịvertis;

$x_{i}$ - rangų suma visų ekspertų atžvilgiu; 
$x_{i j}$ - veiksnio rangas;

$\bar{x}$ - aritmetinis vidurkis;

$\hat{Z}$ - darbuotojo žinios;

$\ddot{Z}$ - žinios;

$\boldsymbol{N}$ - rodiklių rangų sumų nuokrypių nuo jų bendro vidurkio kvadratų suma;

$\aleph_{\max }-$ suma.

\section{Santrumpos}

AHP - analitinis hierarchijos procesas (angl. Analytic Hierarchy Process);

ARAS - sudètinio kriterijaus vertinimo metodas (angl. Additive ratio assessment);

COPRAS - daugiakriterinio kompleksinio proporcingumo vertinimas santykiniu būdu (angl. Complex Proportional Assessment);

EDAS - keleto prieštaringų rodiklių vertinamas (angl. Evaluation based on Distance from Average Solution);

ELECTRE - eliminacijos ir pasirinkimo išreikštos realybès metodas (angl. Elimination and Choice Expressing Reality);

IS - organizacijos informacinè sistema;

IT - informacinès technologijos;

MOORA - metodas, grindžiamas daugiatikslio optimizavimo santykio dydžio analize (angl. Multi-Objective Optimization on the basis of The Ratio Analysis);

NDA - neigiamas atstumas nuo vidurkio (angl. Negative Distance from Average);

PDA - teigiamas atstumas nuo vidurkio (angl. Positive Distance from Average);

PROMETHEE - pirmenybių rangavimo organizavimo metodas vertinimui išgryninti (angl. Preference Ranking Organization Method for Enrichment of Evaluations);

SAW - paprastojo suminio vertinimo metodas (angl. Simple Additive Weighing);

TOPSIS - artumo idealiam taškui metodas (angl. Technique for the Order Preference by

Similarity to Ideal Solution);

VIKOR - kompromisinis rangavimo metodas (angl. Compromise Ranking Method);

ŽS - žinių sinergija. 


\section{Turinys}

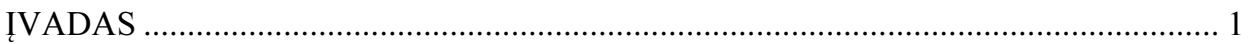

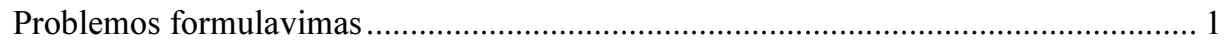

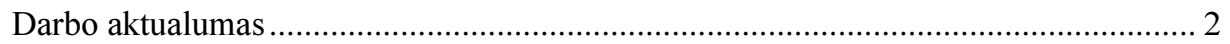

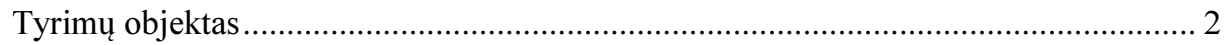

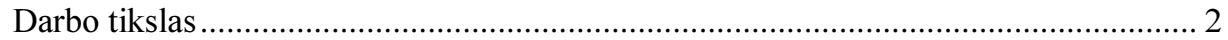

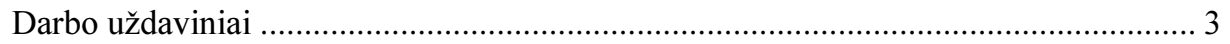

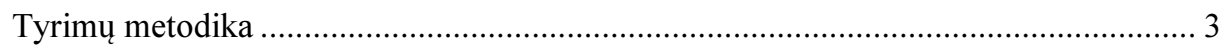

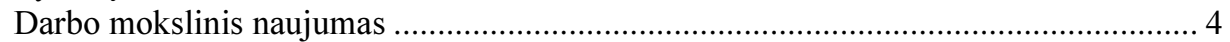

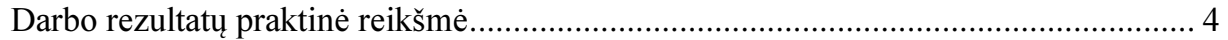

Ginamieji teiginiai ........................................................................................ 5

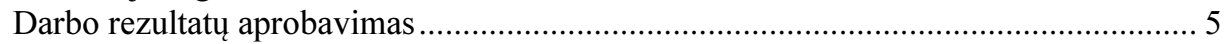

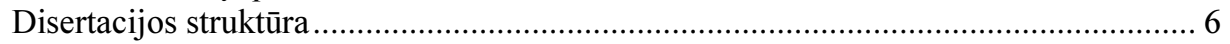

1. ŽINIŲ SVARBA IR VALDYMO PROBLEMATIKA ŠIUOLAIKINĖJE

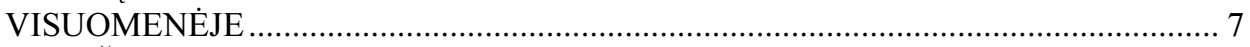

1.1. Šiuolaikinè žinių samprata ir klasifikavimas ...................................................... 8

1.2. Žinių raiškos terpès: nuo besimokančios iki tinklinės organizacijos .................... 16

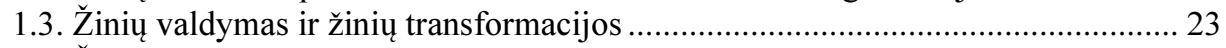

1.4. Žinių sinergija ir jos formavimosi prielaidos...................................................... 26

1.5. Organizacijos aplinkos, palankios formuotis žinių sinergijai, charakteristikos .... 30

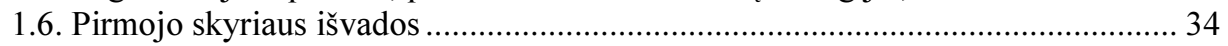




\section{ORGANIZACIJOS DARBUOTOJŲ ŽINIŲ SINERGIJOS VERTINIMO}

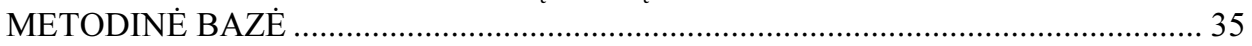

2.1. Vertinimo sampratos į̌zalgos, sinergijos vertinimo metodai ir modeliai ............ 36

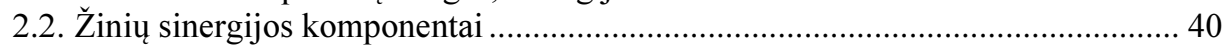

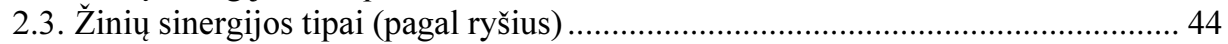

2.4. Siūlymai žinių sinergijos vertinimui..................................................................... 47

2.5.1. Žinių sinergijos komponento - ryšių tarp darbuotojų - vertinimo

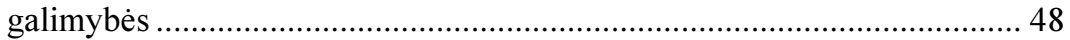

2.5.2. Žinių sinergijos komponento - darbuotojo žinių - vertinimo problemos ir jų

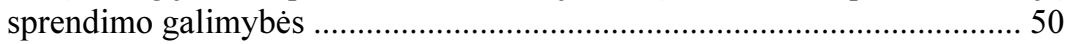

2.5. Antrojo skyriaus išvados ir disertacijos uždavinių formulavimas ......................... 54

3. ŽINIŲ SINERGIJOS VERTINIMO METODŲ RINKINYS ...................................... 57

3.1. Organizacijos darbuotojų žinių sinergijos vertinimo metodai ............................ 57

3.2. Žinių sinergijos komponento - ryšiai tarp darbuotojų - vertinimo siūlymai........ 68

3.3. Žinių sinergijos komponento - darbuotojo žinios - vertinimo metodų pasirinkimo

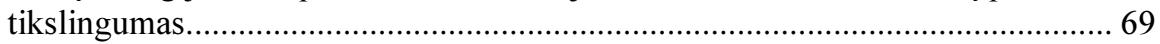

3.4. Daugiakriterinių vertinimo metodų charakteristika ......................................... 76

3.5. Žinių sinergijos komponentų normalizavimas.................................................... 78

3.6. Ekspertų atrankos kriterijai ir nuomonių suderinamumas .................................... 79

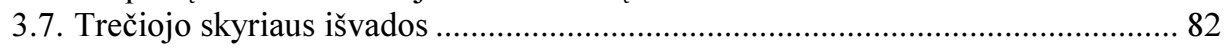

\section{ORGANIZACIJOS ŽINIŲ SINERGIJOS VERTINIMO MODELIO EMPIRINIO}

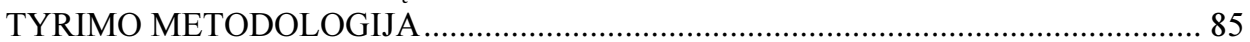

4.1. Organizacijos žinių sinergijos komponento - ryšiai tarp darbuotojų - tyrimo

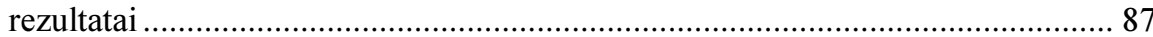

4.2. Organizacijos darbuotojų žinių vertinimo metodų parinkimo pagrindimas.......... 89

4.2.1. Organizacijos darbuotojų žinių vertinimo metodika .................................... 91

4.2.2. Organizacijos darbuotojų žinių vertinimo tyrimo rezultatai...................... 100

4.3. Organizacijos darbuotojų žinių sinergijos vertinimo rezultatų interpretacija ir

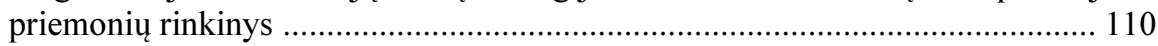

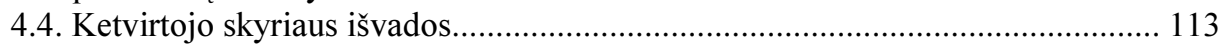

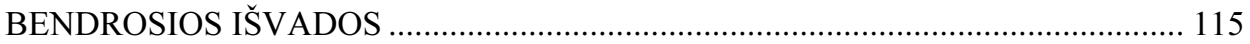

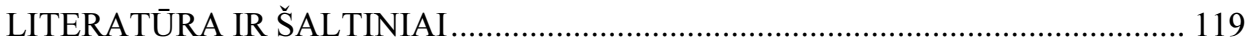

AUTORĖS MOKSLINIŲ PUBLIKACIJŲ DISERTACIJOS TEMA SĄRAŠAS ....... 139

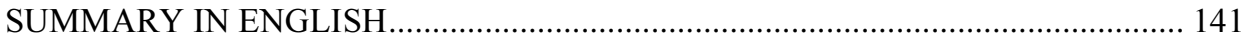

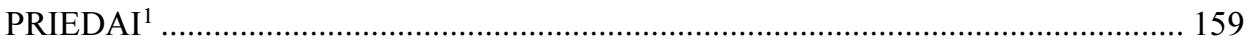

A priedas. Šiuolaikinis žinių apibūdinimas .......................................................... 160

${ }^{1}$ Priedai pateikiami pridètoje kompaktinèje plokštelèje.

xii 


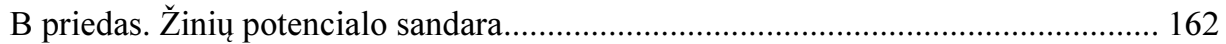

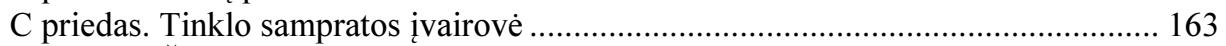

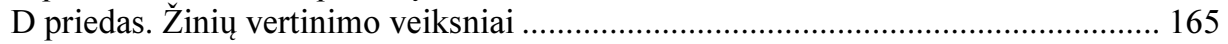

E priedas. Daugiakriterinių metodų klasifikacija...................................................... 169

F priedas. Anketa ekspertams (SAW) ………………......................................... 175

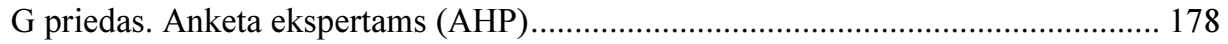

H priedas. Disertacijos autorès sąžiningumo deklaracija......................................... 181

I priedas. Bendraautorių sutikimai teikti publikacijų medžiagą disertacijoje............ 182

$\mathrm{J}$ priedas. Autorès mokslinių publikacijų disertacijos tema kopijos.......................... 188 



\section{Contents}

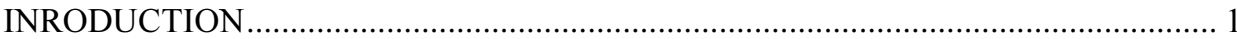

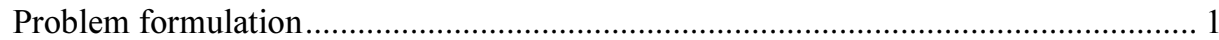

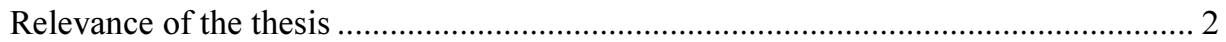

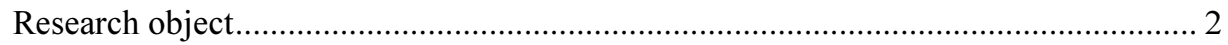

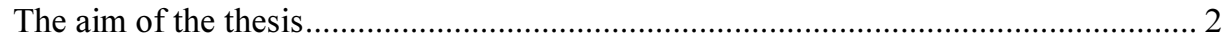

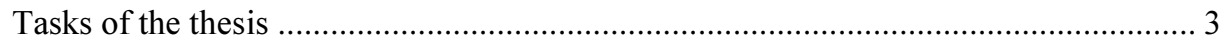

Research methodology ......................................................................... 3

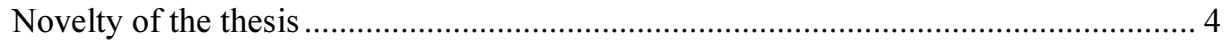

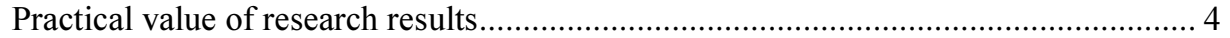

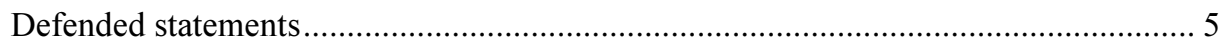

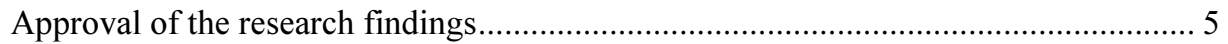

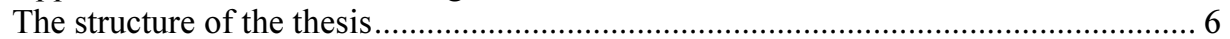

1. SIGNIFICANCE OF KNOWLEDGE IN MODERN SOCIETY AND ITS

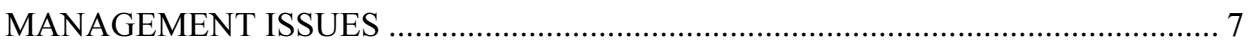

1.1. Modern knowledge concept and classification................................................. 8

1.2. Media for knowledge expression: from learning organisation to network

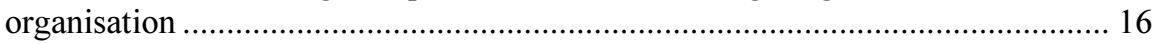

1.3. Knowledge management and knowledge transformations ................................... 23

1.4. Knowledge synergy and preconditions for its formation ................................... 26

1.5. Characteristics of organisational environment favorable to knowledge synergy

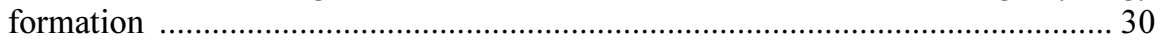


1.6. The conclusions of chapter one

2. METHODOLOGICAL BASE FOR KNOWLEDGE SYNERGY EVALUATION .. 35

2.1. Insights into concept of evaluation, methods and models of synergy evaluation. 36

2.2. Knowledge synergy components ............................................................... 40

2.3. Knowledge synergy types (according to relations)...................................... 44

2.4. Suggestions concerning knowledge synergy evaluation .................................. 47

2.4.1. Evaluation possibilities of knowledge synergy component - relations among

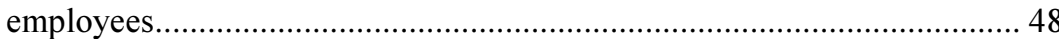

2.4.2. Evaluation problems and possible solutions of knowledge synergy component - employee knowledge ................................................. 50

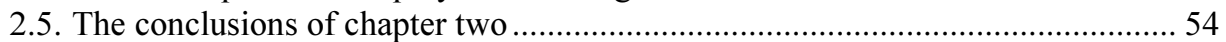

3. SET OF KNOWLEDGE SYNERGY EVALUATION METHODS ....................... 57

3.1. Suggestions concerning organisation employee knowledge synergy evaluation

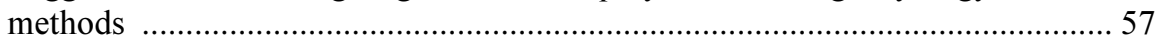

3.2. Suggestions concerning evaluation of knowledge synergy - relations among -

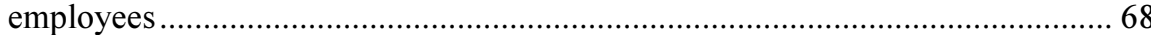

3.3. Appropriateness of choice of evaluation methods of knowledge synergy

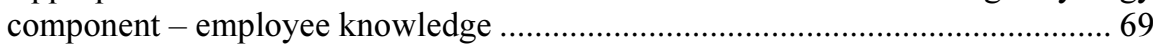

3.4. Characteristics of multicriteria evaluation methods ..................................... 76

3.5. Normalisation of knowledge synergy components ..................................... 78

3.6. Expert selection criteria and compatibility of opinions .................................... 79

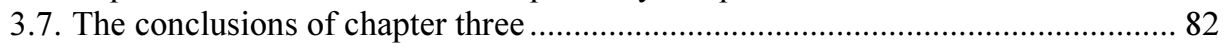

4. EMPIRICAL RESEARCH METHODOLOGY OF ORGANISATION EMPLOYEE KNOWLEDGE SYNERGY EVALUATION METHODS …..................................... 85

4.1. Research outcomes of organisation knowledge synergy - relations among

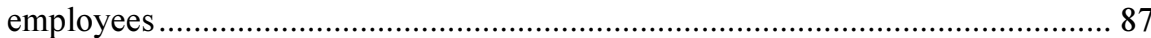

4.2. Justification for selection of organisation employee knowledge evaluation

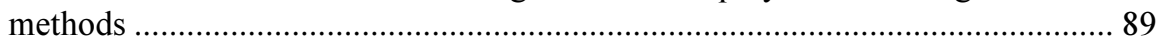

4.2.1. Organisation employee knowledge evaluation methods ........................... 91

4.2.2. Research outcomes of organisation employee knowledge evaluation....... 100

4.3. Interpretation of organisation knowledge synergy outcomes and set of tools .. 110

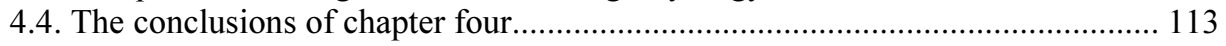

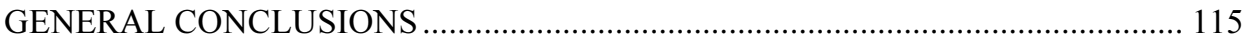

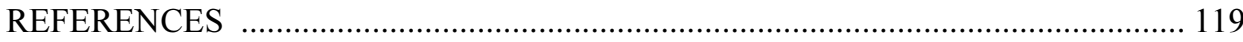

LIST OF SCIENTIFIC PUBLICATIONS BY THE AUTHOR ON THE TOPIC OF

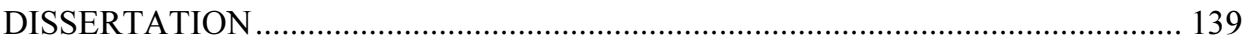

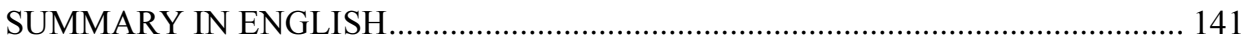




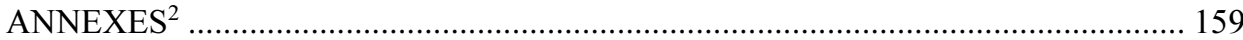

Annex A. Contemporary definition of knowledge .................................................. 160

Annex B. Composition of knowledge potential ........................................................ 162

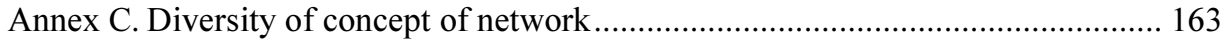

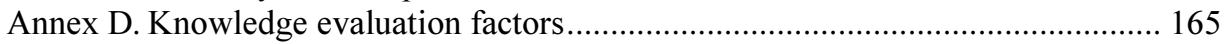

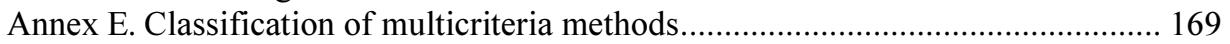

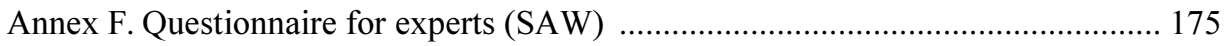

Annex G. Questionnaire for experts (AHP) ....................................................... 178

Annex H. Authors' declaration of academic integrity .............................................. 181

Annex I. The co-authors agreements to provide published material in the thesis ...... 182

Annex J. Copies of scentific publications by the author on the topic of the dissertation

${ }^{2}$ The annexes are supplied in the attached compact disc. 



\section{Ivadas}

\section{Problemos formulavimas}

Vykstant transformacijai iš informacinès i žinių visuomenę keičiasi vartotojų prioritetai ir poreikiai, lemiantys ir organizacijų veiklos pokyčius. Svarbiu ištekliumi tampa ne tik duomenys, informacija, bet ir žinios bei veiksmingas jų valdymas. İvairūs tyrejjai žinias apibūdina savitai, jų darbuose minimos sąvokos „kompetencija“, ,igūdžiai“, „talentas“, ,intelektas“, siūloma vartoti ir platesnio turinio sąvoką ,žinių potencialas“", kuri apima išreikštines (išsilavinimas, kultūra) ir neišreikštines (igūdžiai, gebejjimai, patirtis) žinias, tinkančias sinergijos procesų analizei ir vertinimui. Tokia sąvokų painiava apsunkina žinių srities tyrimus. Auganti žinių svarba bei atsirandanti žinių sinergija, žinių terminologijos įvairovè (nesutaptys), organizacijos darbuotojų žinių sinergijos vertinimo metodo nebuvimas paskatino imtis šios srities išsamių tyrimų.

Atlikus literatūros analizę, galima teigti, kad žinių sinergijos vertinimui skirtų darbų yra labai mažai, dažnai žinios vertinamos kaip intelektinio ir žmogiškojo kapitalo dalis (Kapatyla et al. 2012, Salonius, Lonnqvist 2012). Visi žinių modeliai yra orientuoti i įmonę, jos vertinimą, apskaitą, valdymą, todèl esami vertinimo metodai nesudaro prielaidų ịvairiapusiškai ir kartu objektyviai vertinti žinias. Pabrèžtina, kad žinių sinergijos vertinimo tyrimų stokojama. 
Nors vis svarbesniu šiuolaikinių organizacijų ištekliumi tampa žinios, o kartu ir žinių sinergija, kuri atsiranda darbuotojams bendraujant ir dalijantis žiniomis, vis dèlto iki šiol nèra sukurta instrumentų kaip organizacijos darbuotojų žinių sinergiją ịvertinti, kad galima būtu ją valdyti ir tikslingai naudoti organizacijos veiklai efektyvinti.

\section{Darbo aktualumas}

Sudètingame, ivvairiafunkciniame, nuolat kintančiame pasaulyje visuomenẻ turi gebèti greitai keistis ir būti pasirengusi ateities iššūkiams, o tam reikalingas sisteminis požiūris i žinias ir jų sąveikos procesus, susijusius su sinergijos atsiradimu. Šiuolaikinèje visuomeneje būtina suvokti ir spręsti nuolat kylančias socialinio ir ekonominio gyvenimo, kultūros, mokslo ir technologijų pažangos, aplinkos apsaugos, saugumo bei kitas nuolat kylančias problemas. Ypatingai svarbi mokslinio pažinimo ir studijų sritis, reikalaujanti nepertraukiamų mokslinių tyrimų, orientuotų į naujus iššūkius.

Globalizacijos ir technologiniai procesai, informacinių technologijų pažanga sudaro sąlygas formuotis ir augti žinių ekonomikai bei nulemia visuomenės gebejimą kurti, naudoti ir nuolat atnaujinti žinias, sukuria naujas terpes jų sklaidai bei galimybes formuotis žinių sinergijai. Šiuolaikinès organizacijos susiduria su naujais komunikacijos, valdymo ir žinių dalijimosi iššūkiais, todèl būtini išsamūs žinių tyrimai, kurie sudarytų sąlygas žinių valdymo tobulinimui. Sudetingi visuomenès raidos procesai, sparčiai kintančios verslo sąlygos organizacijas verčia vis labiau orientuotis ị inovatyvių žinių, darnos procesus, todèl žinių bei ryšių tarp darbuotojų tyrimai padès integruoti žinias ì organizacijos veiklas, spręsti konkurencingumo, komunikavimo problemas, o žinių vertinimo bei žinių sinergijos tyrimų rezultatų analizè sudarys sąlygas unikalių strategijų kūrimui, darnos koncepcijos igyvendinimui.

\section{Tyrimų objektas}

Darbo tyrimų objektas - organizacijos darbuotojų žinių sinergijos vertinimas.

\section{Darbo tikslas}

Darbo tikslas - sukurti organizacijos darbuotojų žinių sinergijos vertinimo metodų rinkini, kurio taikymas leistu kiekybiškai ịvertinti organizacijos 
darbuotojų žinių sinergijos komponentus bei sudarytų prielaidas teikti pagrịstus darbuotojų žinių ir ryšių tarp darbuotojų valdymo tobulinimo siūlymus.

\section{Darbo uždaviniai}

Darbo tikslui pasiekti numatyti šie uždaviniai:

1. Išanalizuoti ir kritiškai ịvertinti žinių, žinių sinergijos sampratas, patikslinti žinių ir žinių sinergijos apibrèžtis bei pateikti žinių valdymo problemines sritis.

2. Išnagrinëjus žinių sinergijos turinį, išgryninti žinių sinergijos komponentus ir pateikti šių komponentų vertinimo siūlymus.

3. Sukurti organizacijos darbuotojų žinių sinergijos vertinimo metodų rinkinį, sujungiantį vertinamus organizacijos darbuotojų žinių sinergijos komponentus $\mathrm{i}$ visumą ir sudaranti prielaidas objektyviai įvertinti organizacijos darbuotojų žinių sinergiją.

4. Parengti organizacijos darbuotojų žinių sinergijos vertinimo metodiką, lanksčiai taikomą ivvairiose organizacijose, ir empiriškai patikrinti organizacijos darbuotojų žinių sinergijos vertinimo metodų rinkinio pritaikomumą.

\section{Tyrimų metodika}

Disertacijoje mokslinès literatūros analizè atlikta aprašomuoju metodu, nagrinejjant žinių tyrimų mokslo literatūros šaltinius, žinių vertinimo metodologijas, žinių sampratos požiūrius ir žinių bei sinergijos tyrimų rezultatus, taikyti loginès analizès ir sintezès metodai, o kritinès analizès déka patikslintos žinių, žinių sinergijos sąvokų apibrěžtys. Sisteminès analizès tyrimų metodo taikymas leido išgryninti organizacijos darbuotojų žinių sinergijos komponentus, veiksnius ir jų dedamąsias, kurių matematinèms išraiškoms kurti taikyta grafų teorija, kombinatorika, Būlio algebros dėsniai. Organizacijos darbuotojų žinių sinergijos komponentus jungiant ì visumą taikyti duomenu normalizavimo metodai. Sprendžiant organizacijos darbuotojų žinių sinergijos vertinimo problemas pasitelktas ekspertinis vertinimas, o subjektyvumui eliminuoti - mišrus porinio lyginimo ir anketinès apklausos metodas.

Sukurto organizacijos darbuotojų žinių sinergijos vertinimo metodų rinkinio taikymo lankstumui ir patikimumui patikrinti taikyti matematinis modeliavimas ir testavimas, ekspertinis vertinimas bei daugiakriteriniai vertinimo metodai. 


\section{Darbo mokslinis naujumas}

1. Išanalizavus žinių ir žinių sinergijos turinị teoriškai patikslinta ir išplètota šiuolaikinè žinių apibrèžtis, išryškinant žinių formavimosi procesus, sudaro prielaidas analizuoti organizacijos darbuotojų žinių sinergiją vadybos mokslo plotmeje.

2. Išgryninus žinių sinergijos kompoziciją bei susisteminus vertinimo metodus, kuriuose žinių sinergija nagrinèjama fragmentiškai, pateikti organizacijos darbuotojų žinių sinergijos komponentų - darbuotojų žinios ir ryšiai tarp darbuotojų - vertinimo metodai, leidžiantys nustatyti darbuotojų žinių ir ryšių tarp darbuotojų valdymo spragas.

3. Sukurtas organizacijos darbuotojų žinių sinergijos vertinimo metodų rinkinys sudaro sąlygas metodiškai ir kompleksiškai įvertinti organizacijos darbuotojų žinių sinergijos komponentus, integruoti vertinimo rezultatus ị galutinị įvertį.

4. Parengta organizacijos darbuotojų žinių sinergijos vertinimo metodika taikoma ivairiose organizacijose, o atliktas eksperimentas papildo vadybos mokslą empirinèmis įžvalgomis apie darbuotojų žinių ir ryšių tarp darbuotojų valdymo galimybes bei ịtaką organizacijos darbuotoju žinių sinergijos įverčiui.

\section{Darbo rezultatų praktinè reikšmè}

1. Parengta organizacijos darbuotojų žinių sinergijos vertinimo taikymo metodika leidžia objektyviai įvertinti organizacijos darbuotojų žinių sinergiją, jos komponentus, o atliktas tyrimas ịvairiose organizacijose įrodo šios metodikos pritaikomumą.

2. Ivvertinus organizacijos darbuotojų žinių sinergijos komponentą darbuotojų ryšius - bei atsižvelgiant ị vertinimo rezultatus galima tikslinti darbuotojų ryšius, žinių dalijimosi procesus, keisti arba integruoti naujas žinių dalijimosi bei bendradarbiavimo skatinimo priemones.

3. Ivvertinus organizacijos darbuotojų žinių sinergijos komponentą darbuotojo žinias - galima nustatyti silpnąsias ir stipriąsias žinių valdymo puses, sudarančias sąlygas organizacijos vadovybei priimti pagrįstus sprendimus, susijusius su darbuotojų žinių valdymu, ir numatyti priemones veikloms gerinti. 


\section{Ginamieji teiginiai}

1. Organizacijos darbuotojams dalijantis žiniomis sukuriama žinių sinergija, sudaranti prielaidas gerinti organizacijos veiklą, gali būti ịvertinta taikant kiekybinių metodų rinkinį.

2. Siūlomas organizacijos darbuotojų žinių sinergijos vertinimo metodų rinkinys, grindžiamas darbuotojo žinių ir ryšių tarp darbuotojų kiekybiniu ivverčiu, sudaro galimybę ịvairiapusiškai ìvertinti organizacijos darbuotojų žinių sinergiją, o organizacijos darbuotojų žinių sinergijos vertinimo metodika pritaikoma įvairiose organizacijose.

3. Atlikusios žinių sinergijos vertinimą, organizacijos turi galimybę koreguoti, keisti arba integruoti naujas žinių dalijimosi bei bendradarbiavimo skatinimo priemones, pasiekti geresnių veiklos rezultatų ir taip didinti organizacijos potencialą.

\section{Darbo rezultatų aprobavimas}

Disertacijos tema paskelbti devyni moksliniai straipsniai: keturi recenzuojamuose žurnaluose (Skačkauskienė, Kazlauskienė, Katinienė 2017; Skačkauskienė, Katinienè 2017; Skačkauskienė, Hrušecká, Katinienė, Čepel 2018; Skačkauskienè, Katinienė 2015), keturi - tarptautinèse konferencijų medžiagose (Katinienè 2017; Katinienè, Stravinskienè 2016; Katiniené 2016b; Katinienè, Oželienė 2015). Nagrinèta tematika skaityti pranešimai septyniose mokslinėse konferencijose:

1. Tarptautinejje mokslinèje konferencijoje „Aukštosios technologijos. Verslas. Visuomenè. 2017 m. Borovets, Bulgarijoje.

2. Respublikinèje mokslinèje - praktinèje konferencijoje „Mokslo taikomųų tyrimų įtaka šiuolaikinių studijų kokybei” 2017 m. Vilniuje.

3. Tarptautinejje mokslinejje konferencijoje „Aukštujų mokyklų vaidmuo visuomenèje: iššūkiai, tendencijos ir perspektyvos" $2016 \mathrm{~m}$. Alytuje.

4. Tarptautinejje verslo konferencijoje „Inovacinių ir kūrybinių verslo sprendimų paieška" $2016 \mathrm{~m}$. Vilniuje.

5. Jaunujų mokslininkų konferencijose „Mokslas - Lietuvos ateitis“ 2015 - $2016 \mathrm{~m}$. Vilniuje.

6. Tarptautinèje mokslinejje - praktinèje konferencijoje „Ekonomikos vystymasis: procesai ir tendencijos" $2015 \mathrm{~m}$. Vilniuje. 


\section{Disertacijos struktūra}

Darbą sudaro įvadas, 4 skyriai, bendrosios išvados, literatūros šaltinių sąrašas, autorès publikacijų sąrašas ir 10 priedų. Darbo apimtis - 117 puslapių be literatūros šaltinių ir priedų. Darbe pateikta 34 paveikslai ir 44 lentelès. 


\section{1}

\section{Žinių svarba ir valdymo problematika šiuolaikinëje visuomenëje}

Šiame skyriuje analizuojama žiniu kaip pagrindinio organizacijos ištekliaus svarba vykstant transformacijai iš informacinès ị žinių visuomenę, analizuojamas žinių turinys, sandara, formavimosi procesai, išsamiai aprašoma dviem žinių tipais išskirtos žinių savybès remiantis M. Polanyi $(1962,1967)$ bei I. Nonaka ir H. Takeuchi (1995), patikslinama žinių apibrèžtis, nagrinèjama plačiai vartojama „kompetencijos“ sąvoka. Taip pat skyriuje išsamiai išanalizuojamos žinių raiškos terpès: nuo besimokančios iki tinklinès organizacijos, pateikiamas žinių valdymo modelis ir jame nagrinèjama žinių transformacijų problematika. Skyriuje pateikiama sinergijos samprata ir žinių sinergijos apibrèžtis bei atskleidžiamas žinių sinergijos poreikis asmens, organizacijos ir valstybès lygmeniu. Be to, analizuojami sinergijos nustatymo metodai, deja, neatspindintys žinių sinergijos turinio. Didžiausią ịtaką sinergijai atsirasti daro organizacijos aplinka, todèl skyriuje analizuojamos organizacijos aplinkos, palankios formuotis žinių sinergijai, charakteristikos.

Skyriaus tematika paskelbti keturi autorès straipsniai (Skačkauskienè, Katinienè 2015, Katinienè, Oželienè 2016, Katinienè, Stravinskienè 2016, Katinienè 2017). 


\section{1. Šiuolaikinè žinių samprata ir klasifikavimas}

Postmodernių organizacijų veikla grindžiama žiniomis, o valdymo sékmé priklauso nuo to, kaip gebama racionaliai panaudoti išteklius ir, pirmiausiai, žinias apie būsimas technologijas, vartotojų poreikių, gamtos, aplinkos, pagaliau-žmonių mąstysenos, kultūrinių procesų pokyčius. M. Dave et al. (2012) teigia, kad žinių vadyba sujungia skirtingų tipų žinias ir sukuria sistemą iš dviejų skirtingų elementų: žmogaus ir technologijų. P. J. Beers et al. (2006), B. S. Shum et al. (2011), I. Björkman, D. Welch (2015) teigia, kad norint susidoroti su žinių gausa ir nuolat didejjančiu jų sudètingumu ịvairiose srityse bei norint mokèti įvairiai žvelgti ị problemas ir gebèti atskleisti alternatyvius metodus tas problemas sprendžiant, reikètų naudoti individualius igūdžius ir grupines žinias. I. Reychav, J. Weisberg (2009) teigia, kad žinios, ypatingai neišreikštos, darbuotojui suteikia konkurencini pranašumą organizacijoje. Žinių išteklius yra unikalus, nes nèra išsemiamas kaip materialieji ištekliai. Šiuo metu organizacijos ižžengè ị tokị etapą, kai intelektinio kapitalo vertė keleriopai viršija materialinio turto vertę. Organizacijos turi reaguoti i dinamiškai kintančią aplinką, kai svarbiomis tampa inovatyvios žinios, jų valdymas ir vertinimas įvairių darbuotojų skirtingose veiklose.

1.1 lentelè. Transformacijų etapai (sudaryta autorès)

Table 1.1. Transformation stages (compiled by the author)

\begin{tabular}{|l|l|l|}
\hline Visuomenės tipas & Ūkinè veikla & Ribojantis veiksnys \\
\hline $\begin{array}{l}\text { Agrarine (žemés } \\
\text { ukkio) }\end{array}$ & $\begin{array}{l}\text { ūkinè žmonių veikla siejama su maisto } \\
\text { produktų gamyba }\end{array}$ & $\begin{array}{l}\text { dirbamosios žemès } \\
\text { plotas }\end{array}$ \\
\hline $\begin{array}{l}\text { Industrine } \\
\text { (pramonine) }\end{array}$ & $\begin{array}{l}\text { ūkinè žmonių veikla nukreipta ị prekių } \\
\text { gamybą }\end{array}$ & turimas kapitalas \\
\hline $\begin{array}{l}\text { Žiniu } \\
\text { (informaciné) }\end{array}$ & $\begin{array}{l}\text { ūkinès veiklos pagrindu tampa žinių } \\
\text { kūrimas ir panaudojimas visose žmogaus } \\
\text { veiklose }\end{array}$ & $\begin{array}{l}\text { turimų žinių kiekis } \\
\text { ir turinys }\end{array}$ \\
\hline
\end{tabular}

Apskritai visuomenejje vykstančias transformacijas pagal ūkinę veiklą galima sugrupuoti taip: agrarinè (žemès ūkio), industrinè (pramoninè), žiniu (informaciné) visuomenè (1.1 lentelè). Agrarinè visuomenè (žemès ūkio visuomenè) - ekonominio vystymosi etapas, kai didžiausios pajamos yra gaunamos iš žemès ūkio, investuojama i gamtos išteklių naudojimą, žemès dirbimą - augalininkystę, gyvulininkystę. Industrinè visuomené (pramoninė visuomenè) - ekonominio vystymosi etapas, kai didžiausios pajamos yra gaunamos iš pramonès sektoriaus, investuojama i gamtos išteklių perdirbimą, gamybą. Žinių (informacinè) visuomenè - tai tokia visuomenè, kuri nuolat kaupia informaciją visose mokslo ir pramonės šakose, vèliau apdorodama šią informaciją 
nuolat mokosi ir kuria naujas žinias bei pritaiko šias žinias kasdienejje ir darbinejje veikloje (Karazijienè, Sabonienè 2010).

Mokslininkai (Castells 2007, Kizilhan, Bal Kizilhan 2015) siūlo išskirti ketvirtaji etapą, kurį galima pavadinti žinių tinklų visuomene, kai ekonominès veiklos pagrindu tampa asmenys, turintys tam tikras žinias ir betarpiškai jomis besidalijantys. Vienų autorių (Dubina et al. 2012) teigimu naujos žinios tampa labai svarbios, joms kurti reikia kūrybiško mąstymo, naujų vadybos metodų ir administravimo gebejjimų, inovatyvių veiklos modelių, todèl atsiranda užuominų tokią visuomenę vadinti kūrybiška visuomene. Kiti autoriai (Campbell, Park 2008) teigia, kad šiuo metu itin svarbios tampa komunikavimo priemonès, nes inovacijoms reikalingi gebejjimai atrasti, suprasti, panaudoti, keisti ir keistis žiniomis bei patirtimi, o naudojant informacines technologijas galima greitai susisiekti, dalintis žiniomis, įvairiomis vaizdo, garso, rašytinèmis priemonèmis ir būdais, taip sukuriant bendravimo ir bendradarbiavimo ryšius, todẻl siūloma tokią visuomenę vadinti santykių visuomene. Visgi, daugelis tyrëjų, visuomenès veikejjų, organizacijų vadovų vieningai sutinka, kad šio laikmečio visuomenès ūkinès veiklos pagrindą sudaro žinios, kurios priskiriamos prie nematerialiujų organizacijos išteklių ir yra unikalios bei neišsemiamos kaip materialieji ištekliai. Apibendrinant galima teigti, kad šiuolaikinès organizacijos įžengè ị tokị etapą, kai žinių verte keleriopai viršija materialiojo turto vertę, o turimos ir sukauptos žinios tiek darbuotojui, tiek organizacijai suteikia konkurencinị pranašumą.

Sèkminga organizacija turi saugoti, plèsti ir sudaryti sąlygas žiniomis dalintis tarp darbuotojų, o norint paspartinti efektyvius darbo ir veiklos procesus, keistis informacija. Todèl atsiranda poreikis valdyti žinias, t. y. būtina atkreipti dèmesi i žinių dalijimąsi tarp asmenų, tirti žinių sinergiją ir žinių perdavimo greitį. Tokių žinių sinergijos tyrimų stokojama, jie atlikti epizodiškai, tyrimai ịprastai atlikti tik vienoje verslo veiklos srityje.

Daugelis mokslininkų (Drucker, Peter 1969, Bell 1973, Toffler 1980, Nonaka, Takeuchi 1995) žinias suvokia ir apibrěžia panašiai (A priedas). P. Drucker (1993) teigia, kad žinios žinių visuomenejje yra pagrindinis išteklius, ir žinių darbuotojai tokioje visuomenëje bus dominuojanti darbo išteklių grupè.

Žinių turinys yra platus, jos naudojamos buityje, mokymosi procesuose, plètojant profesinę veiklą, jos apima ịvairias mokslo, meno, kultūros, vadybos, technologiju ir kt. sritis, todèl žinių sąvokos apibréžtys yra skirtingos ir interpretuojamos bei suvokiamos skirtingai. Sąvokai žinios, iš esmès, priskiriamos trys reikšmès. Pirma, ši sąvoka vartojama apibrěžiant žinojimo būseną, kuria reiškiamas susipažinimas, pažinimas, žinojimas apie faktus, metodus, principus, technikas ir pan. Ši ịprasta žinių sąvokos vartosena atitinka tai, kas dažnai vadinama ,žinau apie”. Antra, žinių sąvoka vartojama išreiškiant pakankamą faktų, metodų, principų ir technikų supratimą, gebejjimą juos pritaikyti ką nors realizuojant - tai atitinka ,žinau kaip”. Trečia, žinių sąvoka vartojama 
kalbant apie užfiksuotus ir sukauptus faktus, metodus, principus, technikas ir pan. Kai sąvoka vartojama šia prasme, kalbama apie žinojimą, kuris buvo igytas ir išreikštas (Atkočiūnienė 2009).

Daugelis tyrejuų teigia, kad žinių pagrindą sudaro duomenys ir informacija, nes asmens naudojamoms žinioms būtini duomenys, kurie virsta informacija (duomenys yra įvestis, o informacija - išvestis) ir kuria didesnę vertę sprendžiant problemas, formuojant, vertinant, priimant, igyvendinant sprendimus (Raudeliūnienè, Račinskaja 2014). Žinių esmę sudaro duomenys ir informacija apdorojant duomenis, gaunama informacija, o apdorojant informaciją, kuriamos žinios (1.1 pav.).

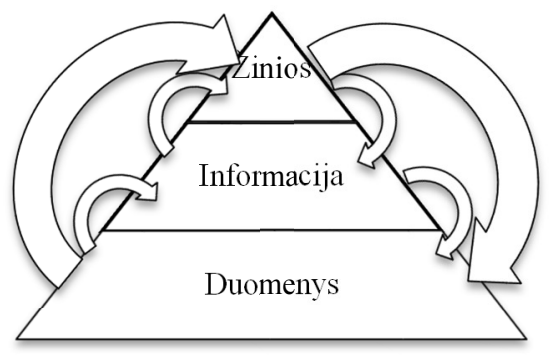

1.1 pav. Žinių sandara (sudaryta autorès)

Fig. 1.1. Knowledge composition (compiled by the author)

Duomenys ịprastai apibrèžiami kaip tam tikrų realaus gyvenimo objektų savybès, charakteristikos, faktai (skaičiai, tekstai, vaizdai, garsai), užrašyti kokiose nors laikmenose ar siunčiami tam tikrais perdavimo kanalais. Naudojami, prasmingi, susieti duomenys tampa informacija, t. y. kai apdoroti duomenys tam tikram subjektui tampa naudingi ir suprantami.

Informacijos terminas yra plačiai vartojamas šiandieninèje būtyje. İpratus prie nuolatinès vartosenos sunku išties sutelkti dèmesị i jo reikšmę, sąvokos turinio ribas, tačiau informacijos sąvoka yra labai sudètinga ir sunkiai nusakoma vienareikšmiškai (Mažeikienè 2009). Informacija (lot. informatio) yra moksliniai, visuomeniniai, politiniai, techniniai duomenys, perduodami vienų asmenų kitiems žodžiu, raštu arba žiniasklaidos priemonèmis (per spaudą, radiją, televiziją, kiną, kompiuteriu tinklus), tai duomenys, turintys prasmę, t. y. objektyviai egzistuojantis pasaulio reiškinys. Informacijos gauname paprasčiausiai kalbėdamiesi su draugais, žiūrẻdami televizorių, skaitydami, informaciją teikiame kitiems išsakydami savo samprotavimus, aptardami įvykius, rašydami laiškus ar žinutes. Net žvilgsnis pro langą mums suteikia tam tikros informacijos. Informacija - tai žmogaus suvoktas objekto turinys.

Informacija dažniausiai traktuojama kaip periferinė moderniosios filosofijos problematika, kelianti paties informacijos fenomeno, bet anaiptol ne informacinio 
tikrovès iprasminimo klausimus (Atkočiūnienè 2009). Informacijos ir komunikacijos mokslo požiūriu informacija suprantama kaip organizuoti faktiniai duomenys, jų tarpusavio ryšiai, apibūdinantys tam tikrą reiškinị, situaciją; informacijai būdingi tam tikri dèsningumai, glaudžiai susiję su jos savybėmis: informacijos kiekio augimas, jos senejjimas ir sklaida. Pastaraisiais metais keičiasi požiūris $\mathfrak{i}$ informaciją, ji apibūdinama kaip išteklius, turintis savybių, būdingų kitiems ekonominiams ištekliams - informaciją galima pirkti, parduoti, apdoroti, ji aktyviai naudojama vertę kuriančiuose procesuose, jos profesionalus valdymas racionalizuoja darbo procesus ir atlieka svarbų vaidmeni formuojant i̇monès strategiją (Atkočiūnienè 2009).

Žinių negalima tapatinti su informacija, kuri yra priimama ir fiksuojama. Žinios tai visiškai naujas požiūris į informaciją, kuris atsiranda sąveikoje su jau egzistuojančiomis žiniomis. J. Vveinhardt (2012) teigia, kad žinios yra sukuriamos iš informacijos ir turi grižtamajji ryši, t. y. žinios gali atnaujinti informaciją. Taigi, žinių terminas yra glaudžiai susijęs ir su duomenimis, ir su informacija (1.2 pav.).

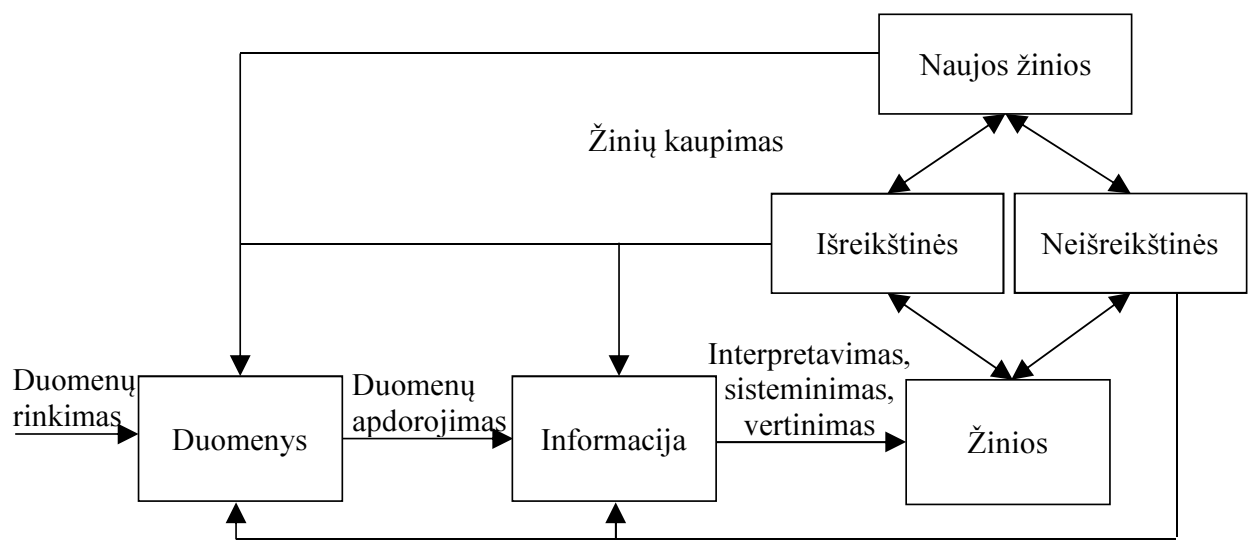

1.2 pav. Žinių formavimosi procesai (sudaryta autorès)

Fig. 1.2. Knowledge formation processes (compiled by the author)

Apibendrinant įvairių mokslininkų darbus galima teigti, kad žinios - tai asmens pažinimo proceso išraiška, formuojama asmeninių charakteristikų ir ji supančios aplinkos bei sudaranti prielaidas asmeniui veikti. Tiriant žinių sinergiją tikslinga naudoti žinių apibrěžț taip išvengiant tiek terminų, tiek žinių turinio painiavos bei būtina suprasti žinių formavimosi procesus ir žinių tipus bei klasifikavimą.

Kaip minèta, žinių turinys yra platus ir įvairus, todèl tyrèjai jas klasifikuoja skirtingai. R. Laužackas (2005) žinias skirsto ị objektyviąsias (mokslines), 
subjektyviąsias (literatūrines, estetines atskiro žmogaus mintis) ir moralines (bendras visuomenines normatyvines nuostatas ir laikysenas). M. Biggs, C. Tang (2013) išskyrę teorinio ir funkcionuojančio žinojimo lygmenis detalizuoja keturių tipų žinias: deklaratyvias (dèsnių, formulių, teorijų, koncepcijų, istorinių įvykių pripažintos žinios), procedūrines (procedūrų, veiksmų atlikimo sekos žinios, t. y. žinios, nusakančios ką daryti veikiant pagal algoritmą), sąlygos (leidžiančios asmeniui suvokti kada, kodèl, kokioms sąlygoms esant turi būti atliekama tam tikra veikla), funkcines (reiškiančios asmens išmanymą, t. y. mokejjimas atrinkti veiklai ar situacijai tinkamas žinias ir jas tinkamai pritaikyti). C. W. Choo (1998) nagrinèja trijų tipu - išreikštas, neišreikštas ir kultūrines - žinias, o M. Boisot (1998) aprašo keturis žinių tipus: asmenines, nuosavybines, visuomenines ir realias, C. Zins (2007) išskiria trijų tipų žinias - praktines (susijusios su funkciniais gebejjimais ir igūdžiais), pažintines (išorinių fizinių objektų ir organizmų pripažinimas arba tiesioginis vidinių reiškinių pripažinimas), teigtinas (pagrisstos teiginiais, išreikštas turinys, ką individas apie tai mano, ką žino).

Žinios gali būti skirstomos pagal egzistavimo pobūdi (Chen et al. 2005, Zins 2007, Kebede 2010) klasifikuojant žinias i subjektyvias ir objektyvias. Subjektyvus požiūris grindžiamas tuo, kad žinios suvokiamos kaip nuolatiniai su žmogaus patirtimi susiję gebējimai bei lemia socialinị elgesį. Objektyvus požiūris skiriasi tuo, kad žinios suvokiamos kaip objektai ar daiktai, t. y.- tai, kas gali būti kaupiama, perduodama, valdoma. R. Maier et al. (2009) apjungé ịvairias mokslininkų siūlomas žinių klasifikacijas bei jų derinius ir pateikè tris aspektus turini, organizaciją, informacines technologijas - žinioms klasifikuoti. S. Strambach (2008) išskiria dvieju tipu - analitines ir simbolines - žinias, o R. Cappettta et al. (2006), R. Martin (2012), M. Jahnke (2013), R. Verganti, A. Öberg, (2013), K. Pina, B. S. Tether (2016) išskiria trijų tipų žinias simbolines (angl. symbolic - akcentuojama ženklų vertè, kuri susijusi su kūrybiškumu, kultūrinių žinių svarba, dominuoja stipri konteksto specifika), analitines (angl. analytic - turinys abstraktus ir universalus) ir sintetines (angl. synthetic - iš dalies kodifikuotos žinios, dominuoja konkretus kontekstas). R. Martin (2012) teigia, jog žinios įvairiais atžvilgiais skiriasi, pavyzdžiui, žinių kūrimo ir naudojimo prasme, vis dèlto reikšmè organizacijai neikainojama.

Mokslinèje literatūroje daugelis tyrèjų (Osterloh, Frey 2000, Smith 2001, Becerra et al. 2008, Reychav, Weisberg 2009, Huang et al. 2011, Vveinhardt 2012, Kothari et al 2012, Hau et al. 2013), dažniausiai nagrinèjančiu žinias, remiasi M. Polanyi $(1962,1967)$ bei I. Nonaka ir H. Takeuchi $(1995)$ išskirtais ir išsamiai aprašytais dviem žinių tipais:

- išreikštinès žinios (angl. explicit), t. y. jau dokumentuotos žinios (specialybès, kultūrinès ir pan.). Jų vadyboje vienas iš lemiamų veiksnių - informacinès technologijos; 
- neišreikštinès žinios (angl. tacit), t. y. nedokumentuotos žinios (darbuotojų igūdžiai, patirtis, talentas ir pan.). Tai žinios susiformavusios dèl asmens mokejjimo suprasti, vertinti, apdoroti gaunamą iš aplinkos ir kitų asmenų informaciją.

Išreikštines žinias valdyti nesudètinga, jas lengva aprašyti, apibūdinti ir pateikti, jų sklaida yra paprasta. Neišreikštines žinias valdyti ịprastais būdais yra neįmanoma. Šių žinių kūrimas ir skleidimas reikalauja kūrybiškumo, inovatyvumo, suvokimo ir kolektyviškumo (Spender, Eden 1998). Y. S. Hau et al. (2013) teigimu, neišreikštines žinias perduoti sunkiau, todèl reikalingas tiesioginis bendravimas. Šios žinios yra sunkiai aprašomos ir kopijuojamos (1.2 lentelè).

1.2 lentelè. Žinių savybès (sudaryta autorès pagal Polanyi 1962, 1967, Nonaka, Takeuchi 1995, Davidavičienè, Raudeliūnienè 2010, Hau et al. 2013)

Table 1.2. Knowledge features (compiled by the author based on Polanyi 1962, 1967, Nonaka, Takeuchi 1995, Davidavičienè, Raudeliūnienė 2010, Hau et al. 2013)

\begin{tabular}{|c|c|}
\hline \multicolumn{2}{|c|}{ Žinių savybès } \\
\hline Išreikštinès & Neišreikštinès \\
\hline Formaliai išreiškiamos & Glūdi pasąmonèje \\
\hline Turètojas žino apie jas & Turètojas gali nežinoti apie jas \\
\hline $\begin{array}{l}\text { Dokumentuotos (raštu, vaizdo ir garso } \\
\text { ịrašais, skaitmeniniu būdu) }\end{array}$ & $\begin{array}{l}\text { Nedokumentuotos, gali būti pastebètos, } \\
\text { tačiau būna neapčiuopiamos }\end{array}$ \\
\hline Lengvai kopijuojamos & Sunkiai kopijuojamos \\
\hline $\begin{array}{l}\text { Gali būti perduodamos tiesiogiai ir } \\
\text { netiesiogiai bendraujant, t. y. } \\
\text { peržiūretos ar išgirstos }\end{array}$ & $\begin{array}{l}\text { Perduodamos tiesiogiai bendraujant, } \\
\text { t. y. negali būti peržiūrètos }\end{array}$ \\
\hline $\begin{array}{l}\text { Saugomos saugyklose (duomenų } \\
\text { bazèse) }\end{array}$ & Laikomos savyje \\
\hline Paprasta sklaida & Sudètinga sklaida \\
\hline Susistemintos & Chaotiškos \\
\hline Pagristos praktika & Pagrịstos refleksais, kūrybiškumu \\
\hline
\end{tabular}

Moksliniais tyrimais įrodyta (Jacobsen, Prusak 2006), jog apytiksliai 80 proc. asmenų, grupių ar organizacijos žinių yra neišreikštos formos ir tik 15-20 proc. vertingu žinių yra užfiksuojama, koduojama ar kokiu nors kitu būdu paverčiama apčiuopiamomis. Be to, autoriai pabrèžia, kad kuo neišreikštas žinias yra sunkiau užfiksuoti, tuo vertingesnès organizacijai jos gali būti. 
Nagrinejjant organizacijos darbuotojų žinias ir joms vertinti plačiai vartojama „kompetencijos“ sąvoka, nors mokslininkai iki šiol nesutaria dèl jos turinio ir taikymo srities. Kai kurie autoriai teigia, kad „kompetencijos“ sąvoka tinka išreiškiamoms ir neišreiškiamoms žinioms apibendrinti. Kiti mano, kad kompetencija yra tik tam tikras veiklos būdas, leidžiantis pasiekti užsibrèžtą tikslą, dar kiti - kad tai asmeninès savybès skirtos tam tikram darbui atlikti (1.3 lentelè).

R. Morkvėnas (2010) pateikia žinių potencialo sandarą, kurioje išskirti išreikštinių ir neišreikštinių žinių blokai ir sinergijos formavimasis jungiantis šioms žinioms. Atlikus žinių potencialo sandaros analizę galima diskutuoti dèl intelekto priklausymo neišreikštinių žinių grupei. Intelektui nustatyti yra sukurti testai, kuriais galima ịvertinti asmens intelekto koeficientą. Dar didesnių abejonių kelia kvalifikacijos priklausymas neišreikštinių žinių grupei. R. Čiutienès ir I. Šarkiūnaitès (2004) manymu, kvalifikacija - tai mokymosi ir lavinimosi proceso rezultatas bei igytu gebejjimų pritaikymas arba profesinis išsilavinimas, darbo patirties, mąstymo gebejimai. Toks apibrèžimas apima išreikštinių ir neišreikštinių žinių dalis, t. y. akivaizdu, kad kalbama apie turimas darbuotojo žinias. Tačiau pažymètina, kad kvalifikacija yra formalizuotos, susistemintos, dokumentuotos žinios, t. y. kvalifikaciją patvirtina dokumentas, o kvalifikaciją apibrežus kaip mokymosi ir lavinimosi proceso rezultatą, ji priskirtina išreikštinių žinių grupei (B priedas).

Žinių turinio analizès objektai (1.4 lentelè) atskleidžia žinių formavimosi daugiapakopiškumą nuo asmens iki išorinès organizacijos aplinkos. E. Sveiby (1997) išskyrė du žinių vadybos aspektus ir du lygius: individualų lygi (dèmesys telkiamas ị asmenų tyrinejjimą ir elgseną) ir organizacinị lygi (dèmesys telkiamas i organizacijos tyrinèjimą ir elgseną). J. Raudeliūnienè ir I. Račinskaja (2014) klasifikuoja žinias i asmens, grupès, organizacijos, sektoriaus, valstybès, regiono. J. Bivainis ir R. Morkvènas (2008) išskiria kumuliacinę penkių pakopų žinių potencialo struktūrą: asmens, darbuotojo, organizacijos, ūkio sektoriaus ir valstybès. Darbuotojas ir asmuo yra persidengiantys elementai. Dirbdamas organizacijoje darbuotojas naudoja ne visas žinias, o turimos jo kaip asmens žinios niekur nedingsta, taigi, darbuotojo žinios yra asmens žinių poaibis ir tai gali būti nagrinèjama kaip vienas elementas. Organizacija yra apibrèžiama kaip grupe žmonių sąmoningai veikianti kartu ir siekianti tam tikro tikslo, vadinasi, grupès ir organizacijos žinių potencialas turètų tureti tokias pat savybes ir galètų būti nagrinèjamas kaip vienas elementas. Taigi, galima teigti, kad analizuojant žinias tikslinga išskirti asmens, organizacijos ir valstybès pakopas. 
1.3 lentelè. Kompetencijos apibrèžtys (sudaryta autorès)

Table 1.3. Competence definitions (compiled by the author)

\begin{tabular}{|c|c|}
\hline Autoriai, metai & Apibūdinimo turinys \\
\hline $\begin{array}{l}\text { D. C. McClelland } \\
1973\end{array}$ & $\begin{array}{l}\text { Asmeninès charakteristikos (natūralus talentas, imlumas } \\
\text { pokyčiams, praktinis talento pritaikymas, būtina } \\
\text { informacija tam tikrai užduočiai igyvendinti), kurios gali } \\
\text { lemti didesnị tam tikros veiklos našumą. }\end{array}$ \\
\hline $\begin{array}{l}\text { R. E. Boyatzis } \\
1982,2008\end{array}$ & $\begin{array}{l}\text { Esminès asmens savybès, kurios teikia galimybę atlikti } \\
\text { efektyvų ar/ir aukštesnès kokybės darbą. }\end{array}$ \\
\hline $\begin{array}{l}\text { D. D. Dubois } \\
1993\end{array}$ & $\begin{array}{l}\text { Darbuotojo gebėjimą ịgyvendinti (ar viršyti) darbinius } \\
\text { reikalavimus atliekant darbą pagal nustatytus kokybės } \\
\text { reikalavimus, atsižvelgiant ị organizacijos vidinę ir } \\
\text { išorinę aplinkas. }\end{array}$ \\
\hline $\begin{array}{l}\text { L. Jovaiša } \\
1993\end{array}$ & $\begin{array}{l}\text { Gebėjimas pagal kvalifikaciją, ignūdžius, žinias gerai atlikti } \\
\text { veiklą, tai ịgaliojimų turèjimas ką nors daryti, t. y. labai } \\
\text { kvalifikuotas žinojimas. }\end{array}$ \\
\hline $\begin{array}{l}\text { K. Coyne et al. } \\
1997\end{array}$ & $\begin{array}{l}\text { Viena kitą papildančių igūdžių ir grupių ar komandų žinių } \\
\text { sąveika, kuri skatina atlikti vieną ar kelis procesus, } \\
\text { atitinkančius pasaulinio lygio standartus. }\end{array}$ \\
\hline $\begin{array}{l}\text { P. Green } \\
1999\end{array}$ & $\begin{array}{l}\text { Darbo ịpročių ir asmeninių ịgūdžių aprašymas siekiant } \\
\text { darbinių tikslų. }\end{array}$ \\
\hline $\begin{array}{l}\text { S. E. Abraham et al. } \\
2001\end{array}$ & $\begin{array}{l}\text { Asmeninių savybių, elgesio ir bruožų rinkinys, reikalingas } \\
\text { sėkmingam darbo atlikimui. }\end{array}$ \\
\hline $\begin{array}{l}\text { F. Weinert } \\
2001\end{array}$ & $\begin{array}{l}\text { Sugebejjimas praktinėmis situacijomis taikyti pagrindinius } \\
\text { tam tikro turinio srities principus ir metodikas. }\end{array}$ \\
\hline $\begin{array}{l}\text { B. Martinkus et al. } \\
2002\end{array}$ & $\begin{array}{l}\text { Žinių ir igūdžių derinimas bei gebejjimas juos pritaikyti } \\
\text { konkrečiomis aplinkybėmis, vadybos funkcijų atlikimas, } \\
\text { atsižvelgiant ị aplinkos ir situacijos apribojimus. }\end{array}$ \\
\hline $\begin{array}{l}\text { K. Lamoureux } \\
2008\end{array}$ & $\begin{array}{l}\text { Aiškiai apibrèžtų igūdžių, elgesio ir žinių rinkinys } \\
\text { naudojamas žmogui vertinti. }\end{array}$ \\
\hline $\begin{array}{l}\text { R. Morkvėnas } \\
2010\end{array}$ & $\begin{array}{l}\text { Tam tikros srities žinojimas, leidžiantis spręsti tos srities } \\
\text { sudėtingas problemas. }\end{array}$ \\
\hline $\begin{array}{l}\text { V. Tūtlys et al. } \\
2015\end{array}$ & $\begin{array}{l}\text { Gebejjimų atlikti tam tikrą operaciją, užduoti realioje ar } \\
\text { imituojamoje veiklos situacijoje visuma. }\end{array}$ \\
\hline
\end{tabular}


1.4 lentelè. Žinių turinio analizès objektai (sudaryta autorès)

Table 1.4. Objects of knowledge content analysis (compiled by the author)

\begin{tabular}{|c|l|l|l|l|}
\hline Požymiai & \multicolumn{4}{|c|}{ Žinių apibūdinimas } \\
\hline Objektai & \multicolumn{1}{|c|}{ Asmuo } & \multicolumn{1}{|c|}{ Darbuotojas } & \multicolumn{1}{|c|}{ Organizacija } & \multicolumn{1}{|c|}{ Aplinka } \\
\hline \multirow{5}{*}{ Tyrèjai } & Platonas, & Drucker, & Bornemann, & Davenport, \\
& Sokratas, & Bornemann, & Sammer, & Prusak, Ulrich, \\
& Aristotelis, & Sammer, & Stewart, & Malchorta, \\
& Ackoff, & Gudauskas, & Leopold, & Stewart, \\
& Albrect, & Ramanauskienè, & Atkočiūnienè, & Leopold \\
& Eulgem, & Bivainis, & Gonzalez, & \\
& Leopold, & Morkvėnas & Martins, & \\
& Lukoševičius, & & Sveiby, & \\
& Probst, Raub, & & Bivainis, & \\
& Romhardt, & & Morkvėnas, & \\
& Ley, Čivilis, & & Raudeliūnienè, & \\
& Stonkiené, & & Račinskaja & \\
& Činčikaitė, & & & \\
& & & \\
\end{tabular}

Kiekvienas asmuo turi unikalias žinias, t. y. kiekvieno žmogaus patirtis, vertybės yra savitos, o tai savo ruožtu formuoja skirtingas žinias. Pastarosios sudaro prielaidas orientuotis ị darbuotojo esminių ir išskirtinių žinių valdymą, savito žinių turinio kaupimą, todèl organizacijos turi siekti išnaudoti sukauptas žinias ir mažiausiomis sąnaudomis kurti naujas.

\section{2. Žinių raiškos terpès: nuo besimokančios iki tinklinès organizacijos}

Kiekvienas žmogus turi daugybę ịvairaus turinio, skirtingos svarbos poreikių nuolatinių ir epizodinių, aiškiai išreikštų ir labai miglotų. Supratus, kad bendromis pastangomis galima lengviau ar geriau patenkinti tam tikrus poreikius, atsirado reikšminga paskata didinti savo galimybes jungiantis i tam tikrus darinius, kuriuose žmonès kokiu nors būdu siejami bendros veiklos (Katinienè, Skačkauskienė 2014). Tiems dariniams pavadinti šiandien populiari sąvoka organizacija. Nèra nei vienos vienodos organizacijos, viena nuo kitos jos skiriasi savita struktūra, unikalia kultūra, skirtinga strategija, darbuotojų patirtimis. Išskiriamos besimokančios, kūrybinès, žinių, tinklinès organizacijos identifikuojant pagrindines ir esmines charakteristikas (1.5 lentelè). 
1.5 lentelè. Organizacijų pagrindinès charakteristikos (sudaryta autorès)

Table 1.5. Main organisation characteristics (compiled by the author)

\begin{tabular}{|c|c|c|c|}
\hline Autoriai & $\begin{array}{l}\text { Organizacijos } \\
\text { tipas }\end{array}$ & Pagrindinès charakteristikos & $\begin{array}{l}\text { Žinių tipu } \\
\text { raiška }\end{array}$ \\
\hline $\begin{array}{l}\text { Senge } 2006 \text {, King } \\
\text { et al. } 2008 \text {, Lyly } 2012\end{array}$ & Besimokanti & $\begin{array}{l}\text { Asmeninis meistriškumas, } \\
\text { sisteminis mąstymas, } \\
\text { grupinis mokymasis, bendra } \\
\text { vizija, naujų žinių } \\
\text { pasidalijimas }\end{array}$ & $\begin{array}{l}\text { Išreikštos } \\
\text { žinios }\end{array}$ \\
\hline $\begin{array}{l}\text { Stankiewicz } 1980, \\
\text { Girdauskienė, } \\
\text { Savanevičienè } 2010\end{array}$ & Kūrybinè & $\begin{array}{l}\text { Gamybos ir kūrybiškumo } \\
\text { pusiausvyra, pasitikèjimas, } \\
\text { motyvacija, žinios, igūužiai, } \\
\text { talentas, naujų žinių kūrimas }\end{array}$ & $\begin{array}{l}\text { Neišreikštos } \\
\text { žinios }\end{array}$ \\
\hline $\begin{array}{l}\text { Mintzberg 1989, } \\
\text { Zdunczyk, } \\
\text { Blenkinsopp } 2007\end{array}$ & Inovatyvi & $\begin{array}{l}\text { Nepastovi ir organiška } \\
\text { struktūra, multidisciplininės } \\
\text { komandos, koordinavimas } \\
\text { vyksta susiderinant, stebimos } \\
\text { ir kuriamos naujos žinios, } \\
\text { daug dėmesio skiriama } \\
\text { inovacinei veiklai }\end{array}$ & $\begin{array}{l}\text { Neišreikštos } \\
\text { žinios }\end{array}$ \\
\hline $\begin{array}{l}\text { Nonaka, Takeuchi } \\
\text { 1995, Millar et al. } \\
\text { 2017, Powell, } \\
\text { Ambrosini } 2017\end{array}$ & Žinių & $\begin{array}{l}\text { Naujų žinių kūrimas, patirties } \\
\text { pasidalijimas, veiklos } \\
\text { dinamiškumas, radikalių } \\
\text { pokyčių reikalaujanti išorinė } \\
\text { aplinka, naudai ir } \\
\text { efektyvumui apjungiama } \\
\text { žinių ir informacijos } \\
\text { duomenų bazes ir žmonių } \\
\text { sugebejjimai }\end{array}$ & $\begin{array}{l}\text { Išreikštos } \\
\text { Žinios } \\
\text { Neišreikštos } \\
\text { žinios }\end{array}$ \\
\hline $\begin{array}{l}\text { Dyllick, Hockerts } \\
\text { 2002, Strohhecker, } \\
\text { Grobler 2012, } \\
\text { Atkočiūnienė } 2013 \text {, } \\
\text { Stuchly, Jasiulewicz- } \\
\text { Kaczmarek } 2014\end{array}$ & Darni & $\begin{array}{l}\text { Reikalingų žinių } \\
\text { identifikavimas ir } \\
\text { išsaugojimas, žmonių, } \\
\text { turinčių vertingas žinias, } \\
\text { išlaikymas, neišreikštinių } \\
\text { žinių transformavimas ì } \\
\text { išreiškiamas koncepcijas ir } \\
\text { modelius, skatinimas dalintis } \\
\text { žiniomis }\end{array}$ & $\begin{array}{l}\text { Neišreikštos } \\
\text { Žinios } \\
\text { Išreikštos } \\
\text { žinios }\end{array}$ \\
\hline
\end{tabular}


1.5 lentelès pabaiga

\begin{tabular}{|l|l|l|l|}
\hline \multicolumn{1}{|c|}{ Autoriai } & $\begin{array}{c}\text { Organizacijos } \\
\text { tipas }\end{array}$ & Pagrindinės charakteristikos & $\begin{array}{c}\text { Žinių tipu } \\
\text { raiška }\end{array}$ \\
\hline $\begin{array}{l}\text { Romme 1996, Castells } \\
\text { 2007, La Rua 2008, } \\
\text { Gotea 2010, } \\
\text { Raeymaekers 2010 }\end{array}$ & Tinklinė & $\begin{array}{l}\text { Žinių perdavimas tinklais, } \\
\text { nuolatiniai ryšiai, nauju }\end{array}$ & $\begin{array}{l}\text { Išreikštos } \\
\text { žinios }\end{array}$ \\
žinių pasidalijimas & \\
\hline
\end{tabular}

E. R. Lyly (2012) teigia, kad sąvoka besimokanti organizacija igavo prasmę kuomet verslo įmonès pasitelkè mokymąsi siekdamos padidinti augimą, konkurencingumą ir atsparumą išorei. Besimokančios organizacijos koncepciją P. Senge (2006) apibūdino kaip procesą, jungiantị kelis esminius elementus, ivardytus disciplinomis: asmeninis meistriškumas; nuostatų keitimas; bendra vizija; komandinis grupinis mokymasis; sisteminis mąstymas. Besimokanti organizacija nuolat apmąsto igytą patirti ir veiklos perspektyvas. Organizacinis mokymasis reiškia žinių, reikšmingų organizacijos tikslams pasiekti bei prieinamų visiems organizacijos nariams, kūrimą ir plëtojimą, o žinios yra inovacijų kūrimo pagrindas (Girnienè 2014).

Kūrybinė organizacija yra išskirtinè, nes stengiasi užtikrinti pusiausvyrą tarp gamybos ir kūrybiškumo, kai siekiama sukurti kūrybišką žinių aplinką, kuri skatina darbuotojus vystyti kūrybinę veiklą, gaminti naujus produktus ar kurti inovacijas individualiai arba komandose, organizacijoje arba bendradarbiaujant su kitomis organizacijomis (Hemlin 2002). Organizacijos lankstumas, organiškumas ir gebejimas prisitaikyti prie nuolat kintančių aplinkos sąlygų yra palaikomi atviros kultūros (Hemlin et al. 2008), skatinančios pasitikèti ir veikti komandose, bei lyderių, kurie įkvepia kurti, leidžia eksperimentuoti ir skatina rizikuoti, igalindami savo darbuotojus (jie sąlyginai gali būti skirstomi i dvi grupes - administratorius ir kūrèjus) veikti ir priimti kūrybinius sprendimus (Girdauskienè, Savanevičienè 2010).

Inovatyvi organizacija pasižymi šiomis pagrindinėmis charakteristikomis: inovacinès veiklos palaikymas organizacijoje, vadybinis potencialas inovacinei veiklai, lyderyste, organizacijos kultūra, mokymasis, inovacinès veiklos organizavimas ir stebėsena organizacijoje, tinklaveika. Bendradarbiavimas organizacijoje dažnai susijęs su tiesioginiu informacijos apsikeitimu, mokymosi procesu, patirties pasidalijimu, net planavimu ar komandų kūrimu. Inovacijų kūrimas ir bendradarbiavimo kultūra organizacijos viduje ir su organizacijos partneriais išorèje yra vienas iš sèkmingos inovacijų plètros aspektų (Šimanskienè et al. 2015).

Viena iš pagrindinių žinių organizacijos ypatybių yra jų paslaugų dinamiškumas, nevienalytis ir laikinas pobūdis (Pina, Tether 2016), todèl veiklos kitimas, radikalių pokyčių reikalaujanti išorinè aplinka, darbuotojų mokymasis ir 
žinios daro didelę įtaką organizacijos sèkmei. Siekiant kuo daugiau naudos ir efektyvumo gali būti sujungiamos žinių ir informacijos duomenų bazès bei drabuotojų sugebejjimai. Žinių organizacijos sẻkmé - dinamiška veikla, reikalaujanti nuolat keistis, prisitaikyti, būti kūrybingu, novatorišku (Millar et al. 2017). Apibendrinant galima teigti, kad, žinių organizacija turi besimokančios, kūrybinès organizacijos bruožų. Apskritai, šiuolaikinès organizacijos, siekdamos sèkmingai vystytis ir išlikti konkurencingos, privalo nuolatos keistis, mokytis ir kurti naujas žinias iššūkius pateikiančioje verslo terpèje (Girdauskienè 2012).

Darni organizacija nèra savaiminis reiškinys; jai igyvendinti būtina sukurti tinkamas sąlygas: identifikuoti organizacijoje darnos iniciatyvų veiksnius, juos skatinančią ir palaikančią vadybos sistemą, tuos veiksnius nuolat plètoti ir tobulinti. Organizacija, siekdama, kad jos nariai ịsitrauktu i ekonomines, socialines bei aplinkosaugines darnos iniciatyvas, privalo ne tik skatinti aiškų bendradarbiavimą, skaidrią komunikaciją, remtis lyderių ir vadovų gerais pavyzdžiais, bet ir remti kūrybiškumą bei inovacijas (Atkočiūnienè 2013). Darnaus konkurencinio pranašumo idèjų kūrejai teigia, kad žinios, kurios apima tai, ką organizacija žino, kaip ji naudojasi tuo, ką žino, ir kaip greitai ji gali sužinoti kažką naujo, yra vienintelis pranašumas, galintis organizacijai užtikrinti ilgalaikę konkurencingą padètį rinkoje (Holsapple et al. 2007). V. Danciu (2013), K. Girotra, S. Netessine (2013), R. A. Katz, A. Page (2013) teigia, kad šiuolaikinès organizacijos neturi kito pasirinkimo kaip tik tapti darniomis. Darna yra jų ateities strategija, o darnumas turi tapti įmonių strategijos dalimi.

Perspektyvia ir efektyvia organizacine forma laikytini įvairūs tinklai, veikiantys nuo šeimos iki visuomenès, ir sudarantys sąlygas ieškoti žinių valdymo problemų sprendimo būdų, padedantys žinių sklaidai. Pasak M. Castells (2007), šiuolaikiniame globalizacijos ir informacinių technologijų vystymosi amžiuje daugelis funkcijų ir procesų igyvendinami pasitelkiant tinklus. Pereinant iš informacinès į žinių visuomenę kinta asmens socialiniai poreikiai, kurie sudaro sąlygas formuotis tinklaveikai. Pastaruoju metu daugelio sričių mokslininkai (La Rua 2008, Gotea 2010, Raeymaekers 2010) ragina tiek praktikams, tiek teoretikams jungtis i tinklaveiką. Organizacijose turètų būti kuriami tinklai ir bendruomenès, kuriose darbuotojai galètų plètoti juos dominančias tematikas, mokytis ir tobuletti (Girnienè 2014).

Tinklinès organizacijos gali skatinti mokymąsi, naują informacijos, kokybiškai besiskiriančios nuo informacijos, kuria anksčiau disponavo atskiri veikejjai, sintezę. Ir tai nèra paprastas informacijos perdavimo tarp dviejų atskirų veikejjų pagerinimas, o greičiau nuolatiniai ryšiai, kurie gali suteikti naujų žinių. Kitaip tariant, tinklas tampa inovacijų vieta. Juk naudingiausia informacija retai 
yra ta, kuri organizacijoje perduodama formalia pavaldumo tvarka, arba ta, kuri gali būti numanoma iš kainų signalų (Ribašauskienè, Šalengaite 2013).

Pasaulyje veikia ịvairūs susivienijimai, konsorciumai ir organizacijos, kurios jungiasi ị žinių tinklus, nes žinias kuria organizacijos nariai, kurie susiję ir su kitomis organizacijomis (Valentim et al. 2015). Organizacijai, siekiančiai sujungti asmens žinias ir panaudoti jas verslo procesams valdyti, vertei kurti, tikslinga naudoti tinklus. Tinklinejje daugiapakopèje žinių sistemoje asmens veikla tampa vis labiau socialiai orientuota ir darosi dar labiau organizuota, inicijuojant jungimąsi į stambesnius darinius tinklo principu (Castells 2007).

R. Keast et al. (2004) išskiria bendrus tinklinių struktūrų bruožus: bendra misija, narių tarpusavio priklausomybè, unikali struktūrinè sąranga. L. N. Radu, D. L. Constantin (2007) papildo tinklo ypatumus tokiais bruožais: nariai priklauso skirtingoms veiklos sritims (pvz., verslui, komercijos ir pramonès rūmams, valdžios ir viešosioms institucijoms, tyrimų institutams, universitetams, socialinėms grupėms), narystė yra savanoriška, dalyvavimas paremtas lygiomis teisèmis, dialogu, konsensusu ir kompromisu bei savivalda, atsižvelgiant i skirtingus interesus. Tinklas veikia juos koordinuodamas ir organizuodamas, tinklo dalyviai neturi galios bausti kitu dalyvių ir teikti nurodymų kitiems partneriams, pagrindiniai sèkmès veiksniai - abipusis pasitikèjimas ir mokymasis vienam iš kito. Anot D. Vidickienès (2008), tinklines organizacijas nuo kito tipo organizacijų skiria tai, kad tinkle bendradarbiavimas vyksta tarp nepriklausomų, bet siekiančių to paties tikslo partneriu, pagrindinis turtas - intelektinis kapitalas, ryšiai tarp narių - savanoriški, jie organizuojami pagal principą „daug su daug“, valdyme dalyvauja mažiau lyderių, bet daugiau organizatorių, nèra nuolatinès organizacinès struktūros. Taigi, tinklinės organizacijos yra patrauklios lygiateisiu bendradarbiavimu, vieno tikslo siekimu, mokymosi vieniems iš kitu galimybe. Daugelis tyrèjų nęžzvelgia grèsmių, kylančių dalijantis informacija tinkle, tokių kaip informacijos nutekejjimas, nuvertejjimas, pasitikejjimas naujomis dar nelabai pritaikytomis praktineje veikloje žiniomis. Vis delto tinklinių organizacijų bruožai, tokie kaip bendra misija, skirtingų sričių žinių sklaida, pasitikejjimu ir dialogu paremtas valdymas suteikia pranašumų.

Šiuolaikinès organizacijos veikia tinkle, todèl tikslinga aptarti tinklo sąvoką, kuri vartojama ivvairių mokslų srityse, dažniausiai aptinkama socialiniuose ir technikos moksluose. Socialiniuose moksluose tinklas nagrinëjamas kaip ryšių tarp žmonių ar organizacijų visuma. Technikos moksluose akcentuojami fiziniai tinklų parametrai, tik informatikoje nagrinejjami virtualūs šiuolaikinių informacinių technologijų tinklai (interneto, telekomunikacijų ir t. t.). Apskritai tinklai dažniausiai analizuojami kaip žmonių ar organizacijų sistemos, informacines technologijas ịvardijant tik kaip priemonę, užtikrinančią komunikaciją tarp šios sistemos elementų (Proscevičienė 2010). 
Socialiniai tinklai tyrinejami sociologijoje, antropologijoje ir socialinejje psichologijoje. Sociologijoje tinklai buvo nagrinejjami komunikuojančių asmenų interaktyvumo požiūriu ir tik vèliau funkcionalistai pradejjo gilintis ị tinkluose vykstančius socialinius santykius, o mainų teorijos šalininkai nagrinejjo ne tik socialinių santykių turinį, bet ir mainų dinamiką. Antropologijoje mainų teorijos buvo išplètotos, akcentuojant santykių turini, jų sąlygas bei vertinimą. Socialinès psichologijos šalininkai gilinosi ị žmonių vaidmenį tinkluose, tačiau buvo apsiribota tik tiesioginių tinklo narių ryšių su centru nustatymu. G. Proscevičienès (2010) teigimu šių trijų mokslo krypčių patirtis tinklų tyrimuose sudare pagrindą tolesniems tinklų tyrimams, o aktyvus ivvairių mokslo krypčių domejjimasis tinklais ir tinkline veikla lemia tinklo sampratų ivaairovę (C priedas).

Tinklaveikos teorija teigia, kad pagrindinis tinklų turtas - intelektinis kapitalas, o svarbiausias šaltinis formuojant ši kapitalą - aktyvus narių ìsitraukimas i veiklą (Vidickienè 2008). Socialinių tinklų analizès pjūvyje socialiniai procesai ir tinklų dalyvių elgsena aiškinama kaip jų pozicijos tinkle rezultatas, tačiau vis didesni mokslininkų susidomejjimą kelia tinklų dalyvių veiksmas tinkluose (Salancik 1995, Ibarra et al. 2005, Joshi 2006, Dhanaraj, Parkhle 2006) - tinklaveika. Tinklaveikos sèkmè ir rezultatai priklauso nuo to, kaip tinkluose aktyviai dalijamasi patirtimi ir žiniomis, kurias sunku perduoti kitaip nei betarpiškai bendraujant, o tai savo ruožtu leidžia kaupti ir didinti žinias.

Tinklaveikai yra būdingas nuolatinis informacijos tekejimas, dvikryptis ir daugiakryptis keitimasis patirtimi ir žiniomis, bendrų veiklų igyvendinimas (European Evaluation... 2010). A. Jakubavičius et al. (2008) teigia, kad tinklaveika - tai tinklo formavimo procesas, kuris apima abipusiai naudingų ryšių tarp potencialių tinklo dalyvių mezgimą bei poveikį egzistuojančiam tinklui ir išskiria tokias labiausiai paplitusias tinklaveikos formas (1.6 lentelè):

- verslo asociacijos;

- technologijų platformos;

- integruoti mokslo, studijų ir verslo centrai (slèniai);

- klasteriai.

Apibendrinant galima teigti, kad žinių skleidimui yra pakankamai daug tinklaveikos formų. Veikdami šiuose tinkluose darbuotojai ar organizacijos gali formuoti ir kaupti inovatyvias žinias, savitas (unikalias) žinias, kurti inovacijas, patrauklius produktus. Esant dideliems informacijos kiekiams tinkle, jungiantis i tam tikras interesu grupes, galima greitai gauti reikiamą informaciją. Sociologų ir organizacijų tyrinètojų teigimu, tinklaveika leidžia dalyvaujantiems darbuotojams igyti naujų igūdžių ir žinių, pagerinti ekonominius rodiklius bei valdyti išteklių poreikị (Podolny, Page 1998). Neretai tinklai tampa vienintele tam tikru klausimu suinteresuotų asmenų grupių bendravimo ir bendradarbiavimo platforma. Tinklaveika sudaro sąlygas skatinančias mokymąsi, nes išsaugoma didesné 
paieškos galimybių įvairovè negu organizacijos struktūros hierarchijos atveju, ir tokiu būdu perduodama vertingesnè bei sudètingesnè informacija.

1.6 lentelè. Tinklaveikos formos (sudaryta autorès)

Table 1.6. Networking forms (compiled by the author)

\begin{tabular}{|c|c|c|c|c|}
\hline Bruožai & $\begin{array}{c}\text { Verslo } \\
\text { asociacijos }\end{array}$ & $\begin{array}{l}\text { Technologijuc } \\
\text { platformos }\end{array}$ & $\begin{array}{l}\text { Mokslo, studiju } \\
\text { ir verslo centrai } \\
\quad \text { (slëniai) }\end{array}$ & Klasteriai \\
\hline Dalyviai & $\begin{array}{l}\text { Panašios } \\
\text { veiklos } \\
\text { dalyviai }\end{array}$ & $\begin{array}{l}\text { Panašios ir/arba } \\
\text { skirtingos } \\
\text { veiklos dalyviai }\end{array}$ & $\begin{array}{l}\text { Skirtingos } \\
\text { veiklos } \\
\text { dalyviai }\end{array}$ & $\begin{array}{l}\text { Panašios ir/arba } \\
\text { skirtingos } \\
\text { veiklos dalyviai }\end{array}$ \\
\hline $\begin{array}{l}\text { Žinių } \\
\text { naudojimo } \\
\text { lygis }\end{array}$ & $\begin{array}{l}\text { Naudoja } \\
\text { turimas žinias }\end{array}$ & $\begin{array}{l}\text { Kuria naujas } \\
\text { žinias }\end{array}$ & $\begin{array}{l}\text { Naudoja naujas } \\
\text { žinias }\end{array}$ & $\begin{array}{l}\text { Naudoja ir } \\
\text { kuria naujas } \\
\text { žinias }\end{array}$ \\
\hline Paskirtis & $\begin{array}{l}\text { Koordinuoti } \\
\text { asociacijos } \\
\text { nariu veiklą, } \\
\text { atstovauti } \\
\text { asociacijos } \\
\text { nariu, kuriuos } \\
\text { sieja kitokio } \\
\text { pobūdžio } \\
\text { bendri tikslai, } \\
\text { interesams, } \\
\text { juos ginti ar } \\
\text { tenkinti kitus } \\
\text { viešuosius } \\
\text { interesus, } \\
\text { taikant } \\
\text { atitinkamas } \\
\text { priemones }\end{array}$ & $\begin{array}{l}\text { Daryti itaką } \\
\text { pramonès ir } \\
\text { moksliniu } \\
\text { tyrimų politikai, } \\
\text { skatinti verslo ir } \\
\text { mokslo plètrą, } \\
\text { didinti } \\
\text { moksliniu } \\
\text { tyrimų } \\
\text { efektyvumą }\end{array}$ & $\begin{array}{l}\text { Atlikti tokias } \\
\text { žiniomis } \\
\text { pagrisstas } \\
\text { veiklas kaip } \\
\text { žinių sklaida, } \\
\text { parama } \\
\text { aukštuju } \\
\text { technologijų } \\
\text { imonèms, ryšiu } \\
\text { tarp žinias } \\
\text { kuriančiu } \\
\text { ịmonių } \\
\text { (universitetų, } \\
\text { mokslo } \\
\text { tiriamųjų } \\
\text { istaigų ir verslo } \\
\text { ịmonių) } \\
\text { kūrimas }\end{array}$ & $\begin{array}{l}\text { Tam tikro } \\
\text { verslo ar } \\
\text { mokslo } \\
\text { susijungimas } \\
\text { kurti naujus } \\
\text { produktus }\end{array}$ \\
\hline
\end{tabular}

Patirties igijimas dalijantis žiniomis, vykdant ịvairias veiklas, nemažai prisideda prie darbuotojo žinių plètojimo. Darbuotojas, turèdamas daug ir įvairių žinių, gali daugiau, geriau, efektyviau dirbti ir kurti didesnę pridètinę vertę organizacijai bei gerinti veiklos rezultatus. 


\section{3. Žinių valdymas ir žinių transformacijos}

P. E. W. Onions (2010) atlikęs 1182 straipsnių, kuriuose nagrinėjamas žinių valdymas, turinio analizę, skirsto tyrimus i dvi kategorijas: praktinius ir teorinius tyrinejimus, bei pastebi, kad juose dažniausiai tiriamos visos žinių rūšys ir žinių valdymas ịvairiais aspektais, todèl atsiranda sunkumų kuriant bendrą žinių valdymo modelị. Norint racionaliai valdyti žinias, būtina ištirti žinių turinị bei žinių valdymo gyvavimo ciklus.

Dar 1962 metais M. Polanyi suskirstė žinias į išreikštines (angl. explicit) ir neišreikštines (angl. tacit). Remiantis tokiu skirstymu I. Nonaka et al. (2000) pateikè žinių valdymo modeli ir aprašè keturis žinių pertvarkymo procesus: socializaciją (angl. socialization), ekspresiją (angl. externalization), derinimą (angl. combination) ir internalizaciją (angl. internalization). Jame mokslininkai išskyrè naudojimo lygmenis ir paaiškino, kaip pereidamos iš vieno - asmeninio lygmens ị kitą - grupini - lygmenị vieno tipo žinios virsta kito tipo žiniomis. Tokie mokslininkai kaip K. M. Wiig (1999), V. Oluic-Vukovic (2001), F. Bouthillier, K. Shearer (2002), K. Dalkir (2005), F. Voehl, J. H. Harrington (2006), T. Andreeva, A. Kianto, (2011) nagrinèjo žinių valdymą išskirdami 5-6 etapus.

F. Voehl ir J. H. Harrington (2006) teigia, kad organizacijos žinių valdymo ciklui būdingi šeši etapai (1.3 pav.): kūrimas (žmonès patys kuria naujus būdus ir metodus darbui atlikti, o metodiką taip pat galima susikurti, bet galima nusipirkti iš išorès), fiksavimas (žinių užfiksavimas, pateikimas suprantama forma), išgryninimas (papildomas neišreikštomis žiniomis), saugojimas (žinių saugojimas suprantama forma, kad galetų naudotis organizacijos nariai), atnaujinimas (žinios turi būti atnaujinamos, tikrinamas jų tikslumas, aktualumas), skleidimas (naujos žinios turi būti pasiekiamos visiems organizacijos nariams).

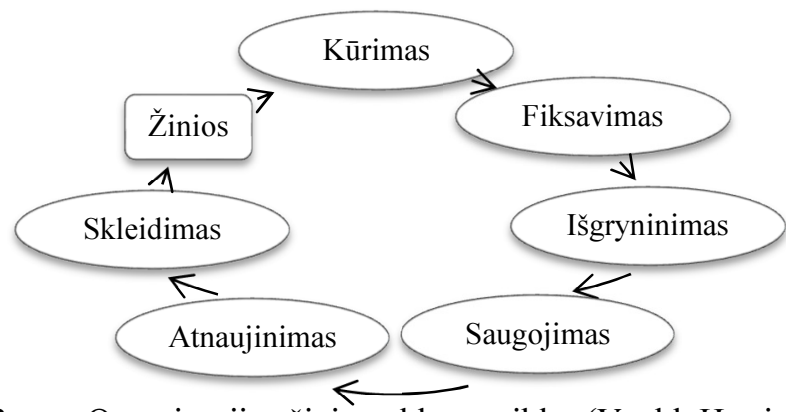

1.3 pav. Organizacijos žinių valdymo ciklas (Voehl, Harrington 2006)

Fig. 1.3. Organisation knowledge management cycle (Voehl, Harrington 2006) 
I. Girnienès (2014) pateiktame integralaus žinių valdymo modelyje išskiriami strateginis, žinių valdymo ir inovacijų blokai. Žinių valdymo bloke pateikiami penki žinių valdymo etapai: identifikavimas, ịsigijimas, kūrimas, dalinimasis, saugojimas. A. Gold et al. (2001), S. C. Pandey, A. Dutta (2013) žinių valdymo tyrimuose išskiria keturis etapus: žinių igijimą, keitimą, vartojimą ir saugojimą.

Išanalizavus tyrèjų pateiktus žinių valdymo modelius abejonių kelia procesų eiliškumas. Pirmasis žinių valdymo modelio ciklo etapas yra identifikavimo, nes turint tam tikras žinias galima kurti bei atnaujinti kitas žinias. Kūrimas ir atnaujinimas yra persidengiančios aibès, nes kuriant naujas žinias atnaujinamos turimos žinios, todèl šiuos du etapus tikslinga sujungti. Vèliau žinioms būtinas saugojimas suprantamu būdu, kad galima būtu jas skleisti, peržiūrèti, tobulinti ir atnaujinti (1.4 pav.).

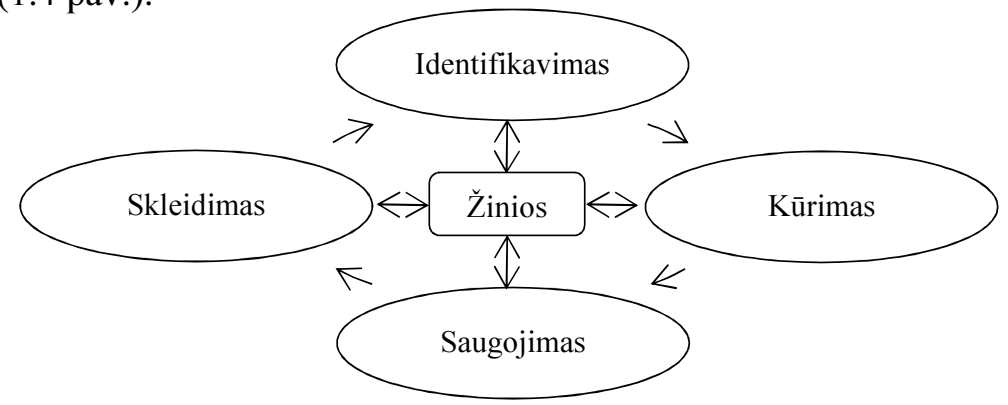

1.4 pav. Organizacijos žinių valdymo ciklas (sudaryta autorès)

Fig. 1.4. Organisation knowledge management cycle (compiled by the author)

Norint valdyti žinias ir veiksmingai išnaudoti žinių sinergiją būtina sistemiškai išnagrinèti žinių valdymo sritis visuose valdymo etapuose ir vykdant tyrimus organizacijose būtina atkreipti dèmesi i į šių sričiu koregavimą. Ištyrus žinių judejjimą bei transformacijas žinių valdymo etapuose nustatyta žinių nutekejjimo, nuvertejimo, priklausomybès, pasitikejjimo žiniomis rizikos probleminès sritys. Šiais sparčios technologijų kaitos laikais aktuali yra žinių sklaidos ir senejimo problema. Asmeniui esant aktyviam rinkos dalyviui ir perduodant žinias kitiems, pastarosios tampa visiems žinomos, praranda savo vertę bei unikalumą, o keičiantis technologijoms - sensta (1.7 lentelè).

Tiriant organizacijos žinių valdymo ciklą daugelis tyrejjų (Dyer, Nobeoka 2000, Hall 2001, Kankanhalli et al. 2005, Wasko, Faraj 2005) įrodè, kad žinių dalijimasis turi teigiamos įtakos darbuotojų motyvacijai, G. W. Bock et al. (2005), H. F. Lin (2007) empiriškai ịrodè, kad abipuse nauda teigiamai veikia darbuotojų požiūrị ị dalijimąsi žiniomis bei daro įtaką darbuotojų ketinimams įsitraukti ị žinių mainus. A. Chennamaneni et al. (2012) taip pat pastebejo, kad abipusis bendravimas skatina darbuotojų norą dalintis žiniomis, C. Dhanaraj et al. (2004) 
ịrode reikšmingą neišreikštinių žinių pasidalijimo poveiki išreikštinių žinių pasidalijimui. Taigi, darbuotojų ketinimai pasidalinti neišreikštomis žiniomis galimi ,žinau-kaip" ("know-how") sudaro sąlygas dalintis išreikštomis žiniomis (Hau et al. 2013).

1.7 lentelè. Žinių valdymo probleminès sritys (sudaryta autorès)

Table 1.7. Problem areas of knowledge management (compiled by the author)

\begin{tabular}{|c|c|c|c|}
\hline Ciklo etapas & Žiniu procesai & Problema & Problematikos turinys \\
\hline \multirow[t]{2}{*}{ Identifikavimas } & $\begin{array}{l}\text { Identifikuotos žinios, } \\
\text { esančios } \\
\text { dokumentuose, vaizdo } \\
\text { ir garso medžiagoje, } \\
\text { t. y. fiksuojama } \\
\text { suprantama forma }\end{array}$ & Pastebimumo & $\begin{array}{l}\text { Ne visos žinios } \\
\text { identifikuojamos, dalis } \\
\text { žinių lieka nepastebetos }\end{array}$ \\
\hline & $\begin{array}{l}\text { Papildomas } \\
\text { neišreikštomis žiniomis }\end{array}$ & Teisingumo & $\begin{array}{l}\text { Žinios gali būti klaidingos } \\
\text { arba teisingos, nes } \\
\text { priklauso nuo } \\
\text { subjektyvaus požiūrio }\end{array}$ \\
\hline \multirow[t]{2}{*}{ Kūrimas } & $\begin{array}{l}\text { Asmenys patys kuria } \\
\text { naujus būdus, metodus } \\
\text { ir metodikas darbui } \\
\text { atlikti, naujai prekei ar } \\
\text { paslaugai kurti }\end{array}$ & Nutekèjimo & $\begin{array}{l}\text { Kai kurios idèjos yra } \\
\text { atmetamos, kaip } \\
\text { netinkamos kūrimo } \\
\text { procesui, todèl tokios } \\
\text { žinios nepasiekia } \\
\text { atitinkamo subjekto }\end{array}$ \\
\hline & $\begin{array}{l}\text { Žinios turi būti } \\
\text { atnaujinamos, } \\
\text { tikrinamas jų } \\
\text { tikslumas, aktualumas }\end{array}$ & Pasitikèjimo & $\begin{array}{l}\text { Sukurtos naujos žinios ne } \\
\text { visada būna tikslios, todèl } \\
\text { reikalingas tam tikras } \\
\text { laiko tarpas, kurio metu } \\
\text { patikrinamas jų } \\
\text { tinkamumas naudoti } \\
\text { organizacijai ir jomis būtu } \\
\text { galima pasitikèti }\end{array}$ \\
\hline Saugojimas & $\begin{array}{l}\text { Žinių saugojimas } \\
\text { suprantama forma, kad } \\
\text { galëtų naudotis } \\
\text { organizacijos nariai }\end{array}$ & Nuvertëjimo & $\begin{array}{l}\text { Saugojamos žinios sensta, } \\
\text { t. y. laikui bėgant } \\
\text { keičiamos naujomis }\end{array}$ \\
\hline Skleidimas & $\begin{array}{l}\text { Naujos žinios turi būti } \\
\text { pasiekiamos visiems } \\
\text { organizacijos nariams }\end{array}$ & $\begin{array}{l}\text { Nuvertèjimo, } \\
\text { pasitikejjimo, } \\
\text { teisingumo }\end{array}$ & $\begin{array}{l}\text { Skleidžiamos žinios gali } \\
\text { greitai nuvertėti, nes jų } \\
\text { unikalumas blèsta. } \\
\text { Perduodamos arba } \\
\text { gaunamos žinios gali būti } \\
\text { klaidingos arba teisingos }\end{array}$ \\
\hline
\end{tabular}


Niekam nekelia abejonių jog žinių identifikavimas itin svarbus etapas, kurio metu būtina ir tikslinga pasidalinti naujomis žiniomis, taip patikrinant ju patikimumą. Kūrimo etape asmenys dalijasi turimomis žiniomis ir kuria naujas žinias, taip pat žinios gali būti perduotos kitam asmeniui, ypatingai tuomet, kai jomis abejojama arba jos yra tikrinamos. Išsaugotos žinios gali būti peržiūrètos, išgirstos, t. y. jomis pasidalinta suprantama forma. Skleidimo etape žinios pasiekiamos ir perduodamos vienų asmenu kitiems. Pastebètina, kad visuose - identifikavimo, kūrimo, saugojimo ir skleidimo - etapuose dalijamasi žiniomis.

R. Morkvėnas (2010) pastebejjo, kad sinergija dažniausiai atsiranda dèl žinių dalijimosi, deja, žinių sinergijos tyrimų žinių valdymo ciklo etapuose nèra, o sinergija, kaip svarbi žinių dedamoji, moksliniuose žinių tyrimuose apskritai yra mažai nagrinèta, nors žinių sinergija, ypač svarbi darbuotojams atliekant pavestas funkcijas, o organizacijai kuriant inovatyvius produktus, numatant savitas strategijas, organizuojant ịvairias veiklas bei išliekant konkurencinejje kovoje.

\section{4. Žinių sinergija ir jos formavimosi prielaidos}

XVII a. viduryje (apie 1650-uosius) atsirado „,bendradarbiavimo“, „dirbti kartu“ arba „dirbti kartu ir padèti vienas kitam darbe" sąvokos, kurios vede iki dabartinès sinergijos sąvokos. Žodis sinergizmas kildinamas iš graikų kalbos ,syn“ (kartu) ir „ergo“" (darbas), tai reiškia veiklą grupejje arba veikimą kartu. Sinergija moksle minima nuo 1925 m., o terminą ,sinergetika“, artimą šiandieniniai sampratai, ìvedè H. Haken 1977 m. pavartodamas ji knygoje „Sinergetika“.

Mokslinejje literatūroje sinergija aiškinama matematinėmis lygtimis: $1+1=3$ (Hamil 1998) ir $1+1+1>3$ (Brigade... 2014). R. Larsson (2002) pateikia tokias sinergijos lygtis: $2+2=5,2+2=4+/-1$ arba $(-2)+(-2)=(-3)$. Dažnai sutinkame ir tokią sinergijos lygti: $2+2=5$ (Smith 2004, Hakeem 2007, Richardson 2007).

Apibendrinant, sinergiją galima apibrèžti matematine nelygybe $\mathrm{x}+\mathrm{x}<2 \mathrm{x}$, bei aprašyti tokia nelygybe:

$$
f(B ; C)>f(B)+f(C),
$$

čia B - pirmasis veiksnys; $\mathrm{C}$ - antrasis veiksnys.

Sinergijai artimas reiškinys yra emerdžizmas (angl. emergence pasirodymas), kai sistema iš kelių elementų (veiksnių) igyja naujų savybių, kurių neturi kiekvienas elementas atskirai. Sinergijos priešingybė yra antagonizmas, kai abiejų veiksnių bendras veikimas yra menkesnis, negu abiejų veiksnių, veikiančių atskirai, poveikių suma:

$$
\mathrm{f}(\mathrm{B} ; \mathrm{C})<\mathrm{f}(\mathrm{B})+\mathrm{f}(\mathrm{C})
$$


K. R. Harrigan et al. (2017) apibrèžiant sinergiją teigia, kad atskirų veiksnių bendro veikimo rezultatas (veikimas) yra didesnis, nei kiekvieno veiksnio veikimo rezultatas (veikimas) atskirai. Sinergija - visuma atskirų sudetinių dalių, sąveika, veikimas iš vien (Staniulienè 2006). Sukurtos sinergijos grožis tame, kad ji tarnauja tik pridèti, niekada atimti (Rententbach 2009). G. R. Lawford (2003), teigia, kad sinergija - tai asmenų, sujungusių savo pastangas ryšiais, grupè. Sinergija tai asmenų mokymosi sąveika ir komandiniu darbu gaunami rezultatai (Hagedoorn, Duysters 2002). Individualiu savybių, žinių, ištekliu sujungimas ir grupeje darbą atliekant kartu bei pasiekiant geresnių rezultatų nei dirbant atskirai (Shannon 1998).

Bendraja prasme, sinergija - tai efektas, kuomet atskiros dalys sujungtos kartu sudaro daugiau, nei kiekviena jų atskirai. Šị terminą dažnai vartoja įvairaus lygio vadovybès nariai, tačiau didžiausia reikšmė suteikiama susijungimų bei ịsigijimų (M\&A) rinkoje. A. Damodaran (2005) išsamiai nagrinejja sinergijos reikšmę ivairiais aspektais susijungus dviem įmonèms. Šis tyrèjas išskiria dvi sinergijos grupes: veiklos ir finansinę. Sinergija išgaunama sujungiant veiklą vykdančius subjektus tuomet, kai šie vykdo panašias funkcijas ir patiria fiksuotas sąnaudas, kurias galima apjungti. Pavyzdžiui, dvi inžinerinès kompanijos turi po labai brangią programinę ịrangą, kuri būtina, tačiau naudojama retai - šioms įmonèms susijungus užtektų vienos programinès ịrangos. W. Cho et al. (2013) nagrinejja ir modeliuoja sinergijos stiprinimą informacinių technologijų srityje. Jų sukurtas modelis gali būti taikomas žinių sinergijos modelio kūrimui, nes tiek žinios, tiek informacinès technologijos, lyginant su kitais ištekliais, turi unikalių savybių. Pagrindiné žinių savybè yra ta, kad jungiantis žinioms sudaromas didelis potencialas sinergijai, kuri yra didesnè nei jos dalių suma, kurtis (French et al. 2008).

Kiekvienas asmuo turi unikalias žinias, t.y kiekvieno žmogaus patirtis, vertybės yra savitos, o tai savo ruožtu formuoja skirtingas žinias, kurios gali būti tikslingai naudojamos organizacijos veikloje. Žinios gali būti perduodamos vienu metu keliems asmenims. Pagrindinè žinių savybė yra ta, kad jungiantis žinioms sudaromos galimybès kurtis sinergijai. Žinių sinergija gali būti pasiekta daugelyje organizacijos veiklos sričių: pagrindinèje veikloje, pritraukiant kapitalą, valdyme, marketinge, moksliniuose tyrimuose, transporte bei logistikoje, mokesčiu optimizavime bei kitur. Apibendrinus žinių ir sinergijos sąvokų analizę, galima teigti, kad žinių sinergija (ŽS) - tai išreikštinių ir neišreikštinių žinių sąveikos procesų, darančių ịtaką asmens ir organizacijos veiklai ir kuriančių naujas žinias, rezultatas.

Kalbant apie žinių sinergiją, neatsiejamas dėmesys turètų būti skirtas ne tik sisteminiam, bet ir holistiniam požiūriui. Pastarojo požiūrio taikymas leidžia išvengti perdèto susikoncentravimo i atskiras nagrinejjamo reiškinio dalis ir užtikrinti, kad nebus pamirštas svarbus analizès aspektas - ryšiai. Kartu atsiranda 
galimybė gauti subalansuotą vaizdą, kuomet išsiaiškinamos ne tik atskiru nagrinejjamo objekto dalių savybès, bet ir jų tarpusavio proporcijos ir ryšiai, duodantys sinergiją (Melnikienè, Vidickienè 2006).

Tiek pasaulio, tiek organizacijos žinių pagrindas - žinių tinklas, kuri sudaro tarpusavio ryšiai. Pažymėtina, kad bendraujant ir bendradarbiaujant, t. y. dalijantis žiniomis, tiek tiesiogiai, tiek tinkluose, greičiau ir efektyviau atliekami darbai, sukuriami inovatyvūs produktai, kuriamos naujos žinios. Veikdami tinkluose asmenys ar organizacijos gali formuoti ir kaupti inovatyvias žinias, savitą (unikalų) žinių potencialą, kurti inovacijas, patrauklius produktus. Europos Sajungos komunikate (2006) pažymima, kad žinių taikymas praktikoje yra ivairialypé ES naujovių strategija, žinios yra pagrindinis ekonomikos plètros, darbo vietų kūrimo ir socialinès gerovès veiksnys. Šiandieninès organizacijos veikia sparčios tinklinès ekonomikos infrastruktūros formavimosi sąlygomis. Tokiame kontekste kiekviena organizacija turetų būti naujos formos: be vidinių barjerų, atvira globaliam bendradarbiavimui ir žinių sklaidai. Šalia to augantis mokslo ir verslo bendradarbiavimas paremtas nauja mąstymo paradigma, suteikia impulsą sinerginiams virsmams visuomenèje, sudaro prielaidas žinių dalijimosi ir žinių sinergijos formavimosi procesams (1.5 pav.). Žinios, kaip žinių ekonomikos pagrindas, yra kaupiamos ir nuolat atnaujinamos plètojant mokslinius tyrimus ir praktinę veiklą.

Kalbant apie žinias, žinių kaupimą, naudojimą ir valdymą, sinergijos poreiki, būtina išanalizuoti organizacijos aplinką, kurioje susidaro sąlygos formuotis žinių sinergijai.

P. Drucker (1980) ir P. Strassmann (1998) vieni pirmujų prabilo apie informacijos svarbą ir žodžiais išreikštas žinias, anot jų - tai vienas iš svarbiausių ir ypatingų išteklių, kuris naudojamas, gali atnešti didelę naudą šalies gerovei. P. Senge (2006) pabrèžia, kad tik atviros ir besimokančios organizacijos galès generuoti didesnę pridètinę vertę, igyti konkurencinį pranašumą, įveikti atsiradusius sunkumus ir gerinti valdymo procesus, sistemiškai kryptingai valdyti ir kurti aplinką, palankią efektyviems žinių valdymo procesams vykti, siekti organizacijos tikslų. Besiformuojančioje tinklinèje ekonomikoje ir žinių visuomenèje organizacijos turi būti pasirengusios sudètingiems žinių sklaidos ir valdymo procesams. Dar 1980 D. Neef et al. žinių vadybą apibrèžè kaip gebejjimą surinkti ir panaudoti žinias, reikalingas naujoms prekèms ir paslaugoms kurti ir gebejimą pasidalyti efektyvios veiklos metodais. M. Polanyi (1962) akcentuoja neišreikštų žinių kodavimą paverčiant jas išreikštomis, asmenybès kūrybiškumą. Taigi, galima teigti, kad unikalios, savitos asmens žinios formuoja unikalią asmens kultūrą ir leidžia pasireikšti kūrybiškumui. Vykstant žinių sklaidai tarp asmenų atsiranda sinergija, kuri generuoja unikalias žinias taip sudarydama sąlygas kurtis savitai organizacijos narių kultūrai. Apskritai žmonijos progresui didžiausią ịtaką turi gebejimas mokytis ir naudoti turimas žinias (Kloudová, 
Chwaszcz 2011), o nūdienos problemoms spręsti, kai susiduriama su sociokultūrinėmis situacijomis, akcentuojama harmoningo žmogaus koncepcija, vadybos teorijos aktualizuoja sistemini požiūrị, orientuotą i profesionalumą, t. y. profesionalų veikimą ir visuotinę kokybès vadybą (Katinienè, Skačkauskienė 2014). C. Landau et al. (2016) teigia, kad konkurencinis pranašumas generuojamas nukreipiant dèmesị i pasaulinę rinką. Apibendrinant galima teigti, kad dalis asmens turimų žinių, naudojamų darbe, didina organizacijos konkurencingumą, o kuo daugiau konkurencingų organizacijų, tuo konkurencingesnè ūkio šaka ir pati valstybè (Jurevičienè, Komarova 2010).

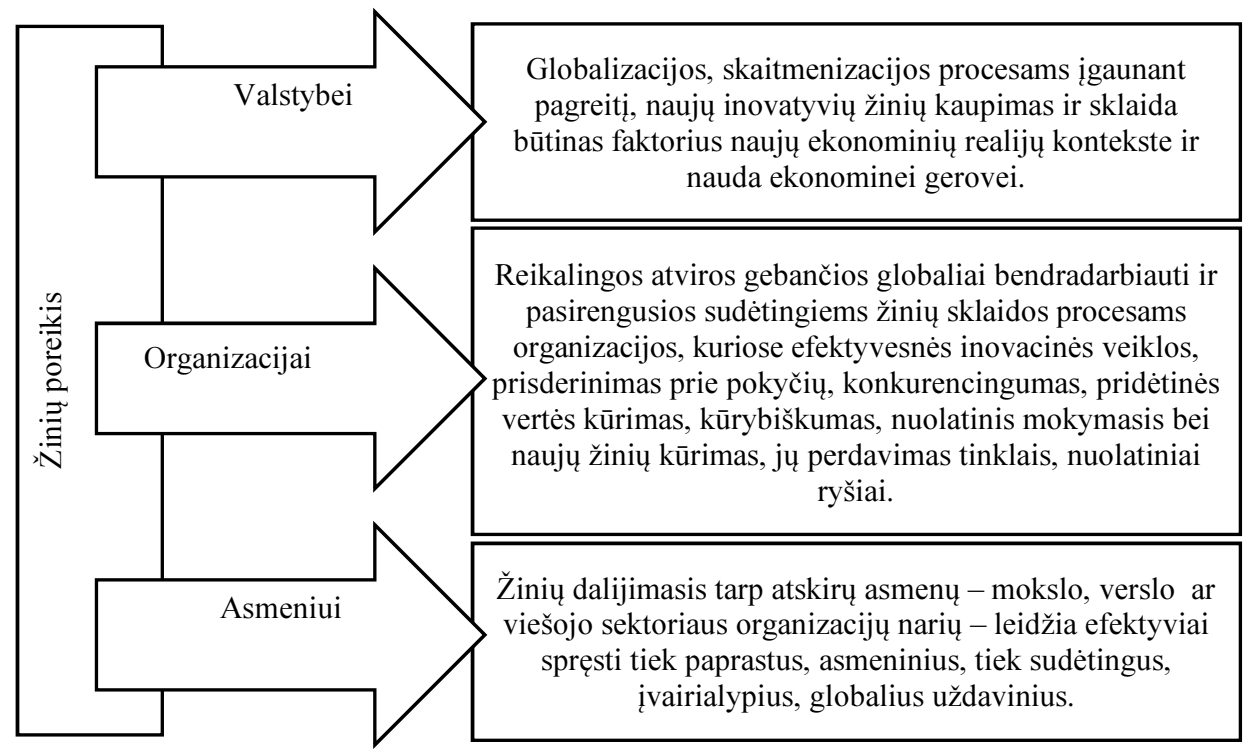

1.5 pav. Žinių sinergijos poreikis (sudaryta autorès)

Fig. 1.5. Demand for knowledge synergy (compiled by the author)

Žinios - žinių ekonomikos pagrindas - yra kaupiamos ir nuolat atnaujinamos plètojant mokslinius tyrimus ir praktinę veiklą. Kai jos ịtraukiamos ị bendrą sistemą organizacijos ar valstybès lygmenyje, dèl sinergijos atsiranda galimybè kurti didelę pridètinę vertę. Taigi, galima teigti, kad žinios yra svarbiausias išteklius organizacijų galimybių vystymui, o sisteminis požiūris ị žinių šaltinius keičia motyvavimo sistemas, žinių valdymą. Organizacijos, igalinusios sinergijos procesus savo veiklose, gali efektyviau naudoti turimus išteklius ir pasiekti geresnių veiklos rezultatų. 


\subsection{Organizacijos aplinkos, palankios formuotis žiniụ sinergijai, charakteristikos}

Didžiausią itaką sinergijai atsirasti daro organizacijos aplinka. Organizacijos aplinka yra aktyvių subjektų ir vidinių bei išorinių objektų visuma, veikianti pačioje organizacijoje ir už jos ribų, todèl ją tikslinga skirstyti į vidinę ir išorinę. Vidinès aplinkos vertinimui būtų galima išskirti tokias dedamąsias: fizinès ir psichologinès aplinkos, inovatyvios žinios. Išorinès aplinkos dedamosios yra tokios: ryšiai su kitomis organizacijomis ir žinių sklaidos greitis. Pasaulyje nèra nei vienos vienodos organizacijos - kiekviena iš jų yra skirtinga, t. y. unikali savo struktūra, tradicijomis, valdymo stiliumi ir pan.

Analizuojant mokslinius darbus, kuriuose nagrinejjama organizacijos aplinka, galima pastebèti, kad vyraujantis kūrybiškas klimatas, nepriklausomai nuo jo raiškos srities ar darbo pobūdžio, generuoja didžiausią sinergiją, kadangi tokioje aplinkoje skatinamas dalijamasis žiniomis, generuojamos naujos žinios, puoselèjamas intelektualumas, laisvès pojūtis (1.8 lentelè).

1.8 lentelè. Sinergijos raiškos organizacijos aplinkoje (sudaryta autorès)

Table 1.8. Expression of synergy in organisational environment (compiled by the author)

\begin{tabular}{|c|c|c|}
\hline $\begin{array}{l}\text { Autorius, } \\
\text { metai }\end{array}$ & $\begin{array}{l}\text { Sinergijai kurtis } \\
\text { palankios } \\
\text { aplinkos }\end{array}$ & Charakteristikos \\
\hline $\begin{array}{l}\text { Grakauskaitė - } \\
\text { Karkockienė } \\
2006\end{array}$ & $\begin{array}{l}\text { Fizinès aplinkos } \\
\text { savybės }\end{array}$ & $\begin{array}{l}\text { Vizualiu detalių gausa; natūralios gamtos } \\
\text { vaizdai už lango arba jų kompensavimas } \\
\text { kambariniais augalais, paveikslais; natūralios } \\
\text { apdailos medžiagos; šiltų spalvų vyravimas arba } \\
\text { malonūs kontrastai. }\end{array}$ \\
\hline $\begin{array}{l}\text { Ekvall } 1997, \\
\text { Dackert } 2001, \\
\text { Sahlin } 2001\end{array}$ & $\begin{array}{l}\text { Kūrybiškas } \\
\text { klimatas }\end{array}$ & $\begin{array}{l}\text { Šilta atmosfera; atvirumas ir kilnumas; } \\
\text { bendrumo, priklausomybès grupei jausmas; } \\
\text { pasitikejimas ir tolerancija; intelektinis } \\
\text { smalsumas, laisvės pojūtis, kai kiekvienas nėra } \\
\text { ippareigotas laikytis formalumų; kompetentingi } \\
\text { kolegos; žinojimas, kas yra žinoma ir kas } \\
\text { nežinoma; saugumo jausmas ir intelektinè } \\
\text { draugyste; pagalba turintiems idèjų; reguliarūs } \\
\text { susitikimai ir keitimasis idèjomis. }\end{array}$ \\
\hline $\begin{array}{l}\text { Stepanossova, } \\
\text { Grigorenko } \\
2006\end{array}$ & $\begin{array}{l}\text { Kūrybinė } \\
\text { aplinka }\end{array}$ & $\begin{array}{l}\text { Integruotos veiklos, kurios skatina smalsumą, } \\
\text { kūrybinị aktyvumą, savarankišką mokymąsi, } \\
\text { holistinị pasaulio suvokimą; kūrybiškumo }\end{array}$ \\
\hline
\end{tabular}


1.8 lentelès pabaiga

\begin{tabular}{|c|c|c|}
\hline $\begin{array}{l}\text { Autorius, } \\
\text { metai }\end{array}$ & $\begin{array}{l}\text { Sinergijai kurtis } \\
\text { palankios } \\
\text { aplinkos } \\
\text { aspektas }\end{array}$ & Charakteristikos \\
\hline & & $\begin{array}{l}\text { pavyzdžiu buvimas ir nedidelis formalus } \\
\text { reguliavimas; emocinis saviraiškos skatinimas; } \\
\text { pakankamas kiekis mokomosios medžiagos; } \\
\text { nereikalavimas pristatyti kūrybos rezultatus. }\end{array}$ \\
\hline $\begin{array}{l}\text { Stankiewicz } \\
2014\end{array}$ & $\begin{array}{l}\text { Pozityvus } \\
\text { organizacijos } \\
\text { potencialas }\end{array}$ & $\begin{array}{l}\text { Aiškus vizijos ir misijos formulavimas, } \\
\text { leidžiantis siekti ambicingų tikslų, vaizduotės ir } \\
\text { emocijų skatinimas; prieiga prie reikalingos } \\
\text { informacijos, saugus informacijos pasidalijimas; } \\
\text { grį̌tamasis ryšys; aiški skatinimo sistema; } \\
\text { vertinamos asmens charakteristikos (žinios, } \\
\text { vaizduotè, vadovavimo gebejimai) ir socialiniai } \\
\text { bei psichologiniai asmens bruožai; motyvavimo } \\
\text { sistema skatinanti kiekvieną asmenị } \\
\text { susikoncentruoti ị rezultatus, o tai skatina } \\
\text { priimti atsakingus sprendimus; laisvos kūrybos } \\
\text { principu taikymas, bendradarbiavimo santykių } \\
\text { skatinimas, ypač atsižvelgiant ị veiklas. }\end{array}$ \\
\hline $\begin{array}{l}\text { Evans } 1996 \\
\text { Kirchhoff } \\
\text { et al. } 2015\end{array}$ & $\begin{array}{l}\text { Kraštutinès } \\
\text { ribos klimatas }\end{array}$ & $\begin{array}{l}\text { Abipusiai naudingų santykių palaikymas, } \\
\text { stiprybių palaikymas siekiant organizacijos } \\
\text { tikslü; asmens savitu savybių ir skirtumu } \\
\text { toleravimas; lankstumas, laisvė pasirinkti. }\end{array}$ \\
\hline $\begin{array}{l}\text { Grakauskaitė - } \\
\text { Karkockienė } \\
2006\end{array}$ & $\begin{array}{l}\text { Psichologinis } \\
\text { klimatas }\end{array}$ & $\begin{array}{l}\text { Pozityvus požiūris ị veiklumą, iniciatyvą, } \\
\text { išradingumą, darbą; gyvenimo prasmingumo } \\
\text { nuostata; kitoniškumo (asmenybės, idejų, } \\
\text { veiklos, siekių) toleravimas; asmens } \\
\text { autonomijos gerbimas - teisès nusišalinti, } \\
\text { vadovauti pačiam sau ir tureti savo požiūrị } \\
\text { pripažinimas; laisve eksperimentuoti, bandyti, } \\
\text { klysti, pradèti iš naujo ir nebūti už tai } \\
\text { pasmerktam ar išjuoktam; žaismingumas, } \\
\text { humoras. }\end{array}$ \\
\hline
\end{tabular}

Apibendrinant sinergijos raiškas organizacijos aplinkoje galima skirstyti i tokias subkategorijas:

- inovatyviu žiniu terpe (žinojimas, kas yra žinoma ir kas nežinoma, intelektinis smalsumas, laisvès pojūtis, laisvos kūrybos principu taikymas, kai kiekvienas nèra ipareigotas laikytis formalumų); 
- bendradarbiavimas (bendrumo, priklausomybès grupei jausmas, pagalba turintiems idèju, reguliarūs susitikimai ir keitimasis idejomis, abipusiai naudingų santykių palaikymas, bendradarbiavimo santykių skatinimas, ypač atsižvelgiant ị veiklas);

- pasitikejimas (pasitikejjimas ir tolerancija, asmens autonomijos gerbimas, kitoniškumo (asmenybès, idèjų, veiklos, siekių) toleravimas, atvirumas ir kilnumas, stiprybiu palaikymas);

- veikimo laisve ir savarankiškumas (asmens autonomijos gerbimas teisès nusišalinti, vadovauti pačiam sau ir turèti savo požiūrị pripažinimas, laisvè eksperimentuoti, bandyti, klysti, pradèti iš naujo ir nebūti už tai pasmerktam ar išjuoktam);

- lankstus rezultaty vertinimas (gyvenimo prasmingumo nuostata, nereikalavimas pristatyti kūrybos rezultatus, lankstumas, laisvė pasirinkti);

- tinkama fizine aplinka (natūralios apdailos medžiagos, šiltų spalvų vyravimas arba malonūs kontrastai, vizualių detalių gausa) (1.6 pav.).

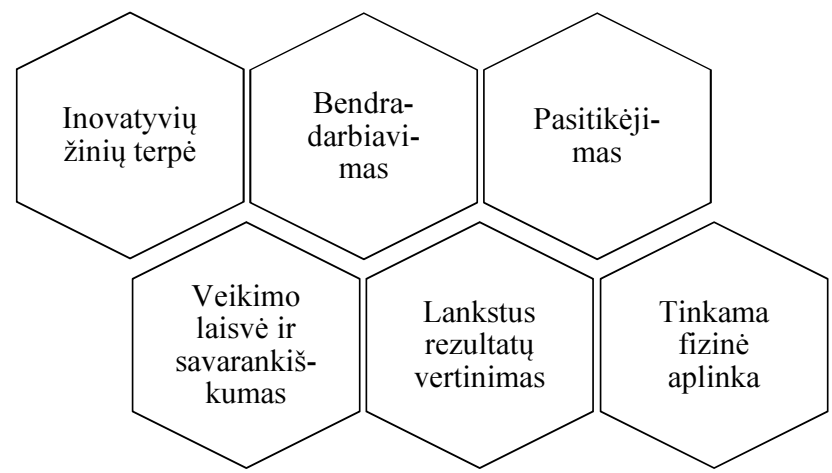

1.6 pav. Organizacijos, palankios aplinkos žinių sinergijai generuoti, subkategorijos (sudaryta autorès)

Fig. 1.6. Subcategories of an organisation, favourable environment for knowledge synergy generation (compiled by the author)

Organizacija gali gyvuoti ir plètotis, jei išorinè aplinka yra pakankamai palanki jos veiklai, o vidinè - yra tinkamai kuriama ir puoselejama, atitinka racionalumo ir optimalumo reikalavimus. Išorinę aplinką galima išryškinti naujais aspektais, pirmiausia atsižvelgiant i tai, kad vykstantys globalizacijos ir integracijos procesai apsprendžia nemažai verslo aplinkos pokyčių. Išorinė organizacijos aplinka - susidarę veiksniai ir tendencijos už organizacijos ribų ir veikiantys jos galimybes atitikti vartotojų poreikius (Assaelis 1999). Išorinè aplinka - tai visi už organizacijos ribų vykstantys reiškiniai, kurie potencialiai gali 
veikti arba faktiškai ją veikia. Pagrindiniai išoriniai (makroaplinkos) veiksniai, tiesiogiai ir netiesiogiai darantys įtaką organizacijos žinių sinergijos apraiškoms, yra (1.7 pav.):

- komunikaciniai veiksniai (ryšiu su partneriais, klientais palaikymas, naujų ryšių užmezgimas, bendravimas ir bendradarbiavimas);

- ekonominiai veiksniai (investicijos moksliniams tyrinejimams bei pridètinès vertès kūrimas ir pavienių veikos sričių išsivystymas);

- kultūriniai veiksniai (sukauptos tradicinès žinios, jų perdavimas, asmens vietos visuomeneje samprata);

- istoriniai veiksniai (egzistuojančios visuomenès požiūriai, turima informacija, jos prieinamumas);

- socialiniai veiksniai (šalies socialinè struktūra, valdymo pobūdis, visuomenès dinamiškumas, organizacijos vidinè aplinka).

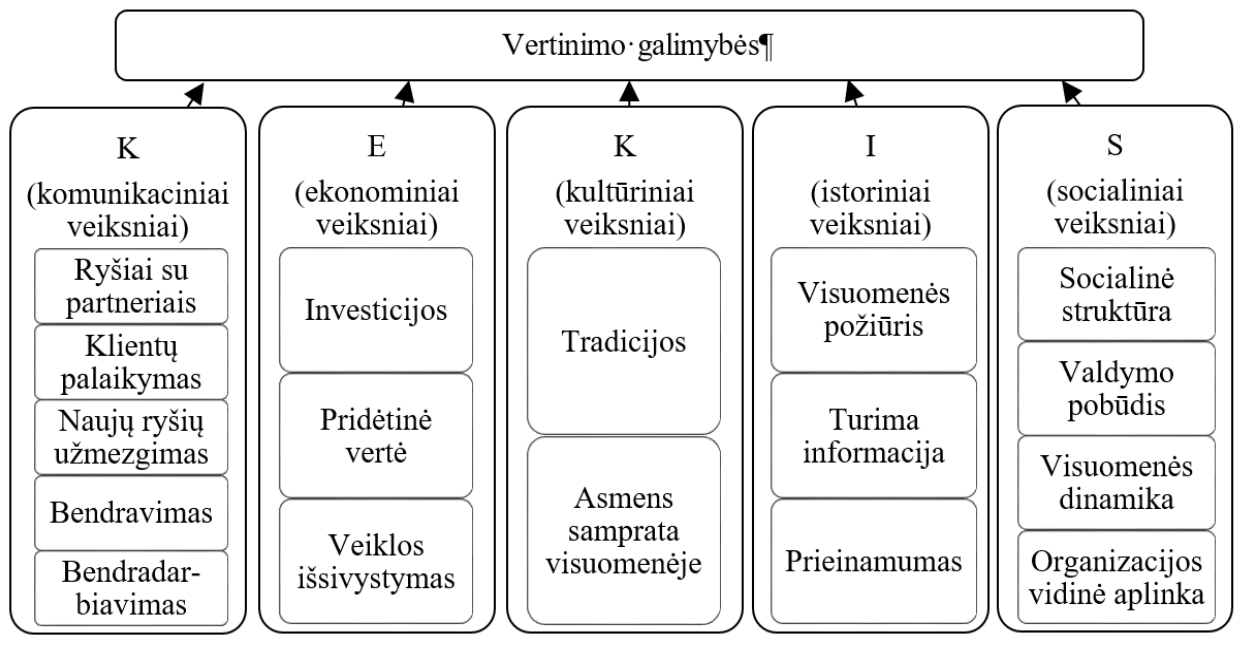

1.7 pav. Aplinkos vertinimo galimybių veiksniai žinių kontekste (sudaryta autorès) Fig. 1.7. Factors of environment evaluation possibilities in knowledge context (compiled by the author)

Šie veiksniai (KEKIS) daro įtaką visuomenès susidomejjimu žinių sklaida, naujų žinių kūrimu ir esamų žinių palaikymu. Minèti veiksniai asmenims sudaro bendrą, nuo jų veiklos nepriklausanti palankios arba nepalankios aplinkos foną, kuris skatina arba blokuoja žinių bei žinių sinergijos formavimąsi. Detaliai išnagrinètos žinių sinergijos palankios aplinkos charakteristikos leidžia pagrịsti sinergijos raišką organizacijos turimose žiniose, o subkategorijų išskyrimas leidžia sukonstruoti išbaigtą instrumentą organizacijos žinių sinergijos tyrimui. 


\subsection{Pirmojo skyriaus išvados}

1. Postmodernių organizacijų veikla grindžiama žiniomis, kurios priskiriamos prie nematerialiujų organizacijos išteklių ir yra unikalios bei neišsemiamos. Apibendrinant įvairių mokslininkų darbus galima teigti, kad žinios - tai asmens pažinimo proceso išraiška, formuojama asmeninių charakteristikų ir ji supančios aplinkos bei sudaranti prielaidas asmeniui veikti.

2. Žinioms vertinti moksliniuose tyrimuose plačiai vartojama „kompetencijos“ sąvoka, deja ši sąvoka neapima visų organizacijos ar darbuotojo turimų žinių, todèl ji labiau tinkama vertinant tam tikrą apibrèžtą darbuotojo veiksmą ir jam keliamus reikalavimus.

3. Išanalizavus pastarojo dešimtmečio paskelbtus mokslinius tyrimus, galima pastebèti, kad vyraujantis kūrybiškas klimatas, nepriklausomai nuo jo raiškos srities ar darbo pobūdžio, generuoja didžiausią sinergiją, kadangi tokioje aplinkoje skatinamas dalijamasis žiniomis, generuojamos naujos žinios, puoselèjamas intelektualumas, laisvès pojūtis. Apskritai, šiuolaikinès organizacijos, siekdamos sékmingai vystytis ir išlikti konkurencingos, privalo nuolatos keistis, mokytis ir kurti naujas žinias iššūkius pateikiančioje verslo terpèje.

4. Norint valdyti žinias ir veiksmingai išnaudoti žinių sinergiją būtina sistemiškai išnagrinèti žinių valdymo sritis visuose organizacijos valdymo etapuose ir vykdant tyrimus būtina atkreipti dèmesị ị šias sritis. Ištyrus žinių judejjimą bei transformacijas žinių valdymo etapuose nustatyta žinių nutekejjimo, nuvertèjimo, priklausomybès, pasitikèjimo žiniomis rizikos probleminės sritys. Šiais sparčios technologijų kaitos laikais aktuali yra žinių sklaidos ir senejjimo problema.

5. Apibendrinus žinių ir sinergijos sąvokų analizę, galima teigti, kad žinių sinergija (ŽS) - tai išreikštinių ir neišreikštinių žinių sąveikos, darančios įtaką asmens ir organizacijos veiklai ir kuriančiu naujas žinias, rezultatas. Pateikta apibrežttis leidžia išskirti žinių sinergijos komponentus bei ịvertinti organizacijos žinių sinergiją. 


\section{2}

\section{Organizacijos darbuotojų žiniụ sinergijos vertinimo metodinè bazé}

Šiame skyriuje pateikiama žinių sinergijos vertinimo samprata, apibrèžtys ir modeliai, išryškinta kiekybinių ir kokybinių vertinimo aspektų problematika, pateikta išsami daugiakriterinių metodų apžvalga, pritaikoma žinių aspektu. Taip pat išanalizuoti sinergijos vertinimo modeliai ir pateikta organizacijos darbuotojų žinių sinergijos vertinimo tolesnių tyrimų schema, identifikuoti pagrindiniai organizacijos darbuotojų žinių sinergijos komponentai - darbuotojų išreikštinès, neišreikštinès žinios ir tarpusavio ryšiai, atlikta šių komponentų vertinimo problemų analize bei pateikti žinių sinergijos komponentų vertinimo siūlymai ir jų sprendimo galimybès. Pažymètina, kad toliau naudojama žinių sinergijos sąvoka yra sinonimas organizacijos darbuotojų žinių sinergijos sąvokai.

Skyriaus tematika paskelbtas vienas autorès straipsnis (Skačkauskienė, Kazlauskienè, Katinienè 2017). 


\subsection{Vertinimo sampratos ižvalgos, sinergijos vertinimo metodai ir modeliai}

Vertinimo sąvoka vartojama daugumoje mokslo krypčių: edukologijoje, medicinoje, politikoje, matematikoje, informatikoje, vadyboje ir kt. Mokslinèje literatūroje yra daug vertinimo apibrèžimų. Vertinimo samprata priklauso nuo daugelio aplinkybių: vertinimo tikslo (naudinga informacija, atskaitomybé, veiklos tobulinimas), vertinamo objekto (programa, organizacijos veikla), srities (švietimas, energetika, kultūra, technologijos), teorinio ir praktinio vertinimo perspektyvų, vertinimo tipo (išorinis, vidinis, apibendrinantis, formuojantis), vertinimo koncepcijos ar modelio (orientuotas i tikslą vertinimas, reaguojantis vertinimas, veiklos teorija grindžiamas vertinimas), vertinimo plačiaja prasme konteksto (politinè, ekonominè, organizacinè ir pan. aplinkos, vertinimo kultūra). Dèl šiu priežasčių vertinimas yra labai lankstus, bet kartu ir neaiškus terminas.

M. Alkin 2004 vertinimą vadina moksliniu tyrimu, apimančiu griežtai atsitiktinių tyrimo metodų sistemini pritaikymą visuomenei aktualios problemos masto matavimui ir socialiai orientuotu programu igyvendinimo, santykinio efektyvumo, išlaidų veiksmingumo santykio įvertinimui. Vertinimas - tai tyrimo procedūrų sisteminis taikymas socialiai orientuotų programų koncepcijai, igyvendinimui ir naudingumui įvertinti (Rossi et al. 2004).

Vertinimo rezultatu panaudojimą pabrěžiantys mokslininkai vertinimą supranta labai ịvairiai. Jų apibrěžimai susiję su tokiais reikšminiais žodžiais: „sprendimu priemimo procesas“, „dalyvavimas vertinimo procese“ „atskaitomybe““, „veiklos tobulinimas“. Šiuo požiūriu aiškiai vertinimą apibrèžè D. Stufflebeam (2007). Jis teigè, jog vertinimas yra veiklos konteksto, idejjimu, proceso ir rezultatu ciklas sprendimu prièmimo procese (Stufflebeam 2007). M. Q. Patton (1990) vertinimą laiko veikla, kurios tikslas - generuoti praktiniam panaudojimui skirtą informaciją apie vertinamo objekto vertę. Anot M. Alkin (2004), vertinimą svarbu suvokti kaip tam tikro objekto vertės nustatymo procesą, kurio metu esminis vaidmuo skiriamas ne vertintojui, o pagrindiniams vertinimo informaciją naudojantiems subjektams. Apibendrinant galima teigti, kad vertinimas yra nuolatinè organizacijos veiklos tobulinimo prielaida, o žinių sinergijai tirti ir atlikti vertinimą organizacijos turimų žinių aspektu, tikslinga apžvelgti sinergijos vertinimo metodus ir modelius.

Sinergijos procesai plačiai analizuojami techniniuose moksluose (pavyzdžiui, šilumos pernešimo charakteristikoms aprašyti, lazerių veikimui pagristi), o organizacijos lygmenyje sinergija žinių aspektu nèra pakankamai tirta. Daugelis tyrejų (Wei-Ping Wu, Choi 2004, Khan 2010, Ketchen, Hult 2011, Fombelle et al. 2011, Cho et al. 2013, Kirchhoff et al. 2015, Harrigan et al. 2017) kalba apie sinergijos naudą, vis dèlto ne daugelis ryžtasi ją modeliuoti bei skaičiuoti. 
I. Steiner (1972) i faktinio našumo formulès skaičiavimą kaip vieną iš komponentu įtraukè sinergiją (9 lentelè). R. Smith, A. Farquhar (2000) pateikè tinklo galios formulę, tinkamą žinių sklaidos procesams tinkle skaičiuoti. D. Belohlavek (2007) aprašè indekso dedamujų esmines charakteristikas ir jų turini, bet nepateikè gilesnès analizès, kaip išskirtas dedamąsias vertinti. K. Eikenberry (2007) teigia, kad sinergija teikia naudą, kuri kinta pagal eksponentini dèsnị. Vis dèlto šio tyrèjo pasiūlytos formulès taikymas yra gana problematiškas esant dideliam skirtumui tarp sutariančių ir nesutariančiu organizacijos asmenų. R. Morkvènas (2010) sinergijai skaičiuoti siūlo tris dedamąsias: žinių multiplikatorių, efektyvių ryšių normą ir vidutinị darbuotojų žinių potencialą, tenkantị vienam ryšiui. Atidžiau išanalizavus dedamụjų formules iškyla neaiškumų dèl formulių taikymo loginès sekos ir paskirties, o tai sunkina skaičiavimus (2.1 lentelè).

2.1 lentelè. Sinergijos vertinimo pavyzdžiai (sudaryta autorès)

Table 2.1. Synergy evaluation examples (compiled by the author)

\begin{tabular}{|c|c|c|}
\hline Autorius, metai & Formulè & Apibūdinimas \\
\hline $\begin{array}{l}\text { I. Steiner, } \\
1972\end{array}$ & $\begin{array}{l}\overline{\bar{N}}=\overline{\bar{G}}+S-\overline{\bar{T}}, \\
\text { čia } \overline{\bar{N}}-\text { faktinis našumas; } \overline{\bar{G}}- \\
\text { našumo potencialas; } S- \\
\text { sinergija; } \overline{\bar{T}}-\text { trukdžiai. }\end{array}$ & $\begin{array}{l}\text { Sinergija traktuojama kaip } \\
\text { faktinio našumo dedamoji. }\end{array}$ \\
\hline $\begin{array}{l}\text { R. Smith, } \\
\text { A. Farquhar, } \\
2000\end{array}$ & $\begin{array}{l}\ddot{G}=\ddot{Z} \ddot{S} \\
\text { čia } \ddot{G}-\text { galia; } \ddot{Z}-\text { žinios; } \ddot{S}- \\
\text { sklaida. }\end{array}$ & $\begin{array}{l}\text { Tinklo galios (angl. } \\
\text { Network Power) formulè } \\
\text { labiau tinkama žiniu } \\
\text { sklaidos procesams tinkle } \\
\text { skaičiuoti. }\end{array}$ \\
\hline $\begin{array}{l}\text { D. Belohlavek, } \\
2007\end{array}$ & $\begin{array}{l}S=\widehat{G} \cdot \widehat{D} \cdot \widehat{V} \\
\text { čia } S \text { - sinergija; } \widehat{G}- \\
\text { individualūs gebèjimai; } \widehat{D}- \\
\text { komandinis darbas; } \widehat{V}-\text { darbo } \\
\text { pridètinè vertè. }\end{array}$ & $\begin{array}{l}\text { Organizacijos sinergijos } \\
\text { indeksą sudaro trijų } \\
\text { dedamujų sandauga. }\end{array}$ \\
\hline $\begin{array}{l}\text { K. Eikenberry, } \\
2007\end{array}$ & $\begin{array}{l}I_{S}=E^{(f-b)} \\
\text { čia } I_{S} \text { - asmens sinergija; } E- \\
\text { asmens energija; } f- \\
\text { sutariančiu asmenų } \\
\text { komandoje skaičius; } b- \\
\text { nesutariančiu asmenų } \\
\text { komandoje skaičius. }\end{array}$ & $\begin{array}{l}\text { Asmens sinergijos } \\
\text { skaičiavimui taikoma } \\
\text { formulè, kuri sudaryta pagal } \\
\text { eksponentinio didejimo } \\
\text { dèsnị. }\end{array}$ \\
\hline
\end{tabular}


2.1 lentelès pabaiga

\begin{tabular}{|c|c|c|}
\hline Autorius, metai & Formulè & Apibūdinimas \\
\hline $\begin{array}{l}\text { R. Morkvėnas, } \\
2010\end{array}$ & $\begin{array}{l}P_{s l}=m_{\check{z}} \cdot r_{e} \cdot p_{v} \\
\text { čia } P_{s l}-\text { organizacijos žinių } \\
\text { potencialo sinergija; } m_{\check{z}-}-\text { žiniu } \\
\text { multiplikatorius; } r_{e}- \\
\text { efektyvių ryšių norma; } p_{v}- \\
\text { vidutinis darbuotojų žinių } \\
\text { potencialas, tenkantis vienam } \\
\text { ryšiui. }\end{array}$ & $\begin{array}{l}\text { Organizacijos žinių } \\
\text { potencialo sinergijai } \\
\text { skaičiuoti naudojama trijų } \\
\text { dedamujų sandauga. }\end{array}$ \\
\hline
\end{tabular}

Pateiktos formulès neatspindi žinių sinergijos turinio ir išsamaus skaičiavimo, yra fragmentiškos sinergijos ir jos dedamujų skaičiavimo požiūriu. Galima teigti, kad tinklo galios (Smith, Farquhar 2000) ir asmens sinergijos (Eikenberry 2007) formulèse skaičiavimai negalimi tada, kai laipsnio reikšmè tampa didelè. Laipsninès funkcijos naudojimas sinergijos vertinime apsunkina skaičiavimus. Apžvelgus formulių dedamąsias ir sudètingumą galima teigti, kad D. Belohlavek (2007) ir R. Morkvèno (2010) formulès savo principine forma gana panašios.

Sinergiją kaip vieną iš efektyvių veiklos resursu nagrinejo M. A. Q. Curley (1998) ir pateikè sinergijos modelị, kuriame išskyre tris lygius (pagal išlaidas): pacientų, personalo ir organizacijos. Tačiau, šiame modelyje neatsispindi procesai, neaiškios dedamujų charakteristikos, be to šis modelis skirtas tam tikrai sričiai, t. y. ligoninèms bei gydymo įstaigoms. Šioje srityje tyrimus tęsé M. G. Titler (2004), R. A. Smith (2006), o R. Kaplow ir S. R. Hardin (2007) išsamiai aprašè šio modelio taikymą. R. D. Lasker et al. (2001) savo tyrime apie bendravimo ir partnerystes sinergiją teigia, kad sinergija yra unikali bendradarbiavimą gerinanti priemonè organizacijoje ir pateikè schemą, kurioje atsispindi partnerystès sinergijos vieta (2.1 pav.), tačiau ir šis modelis skirtas gydymo įstaigoms.

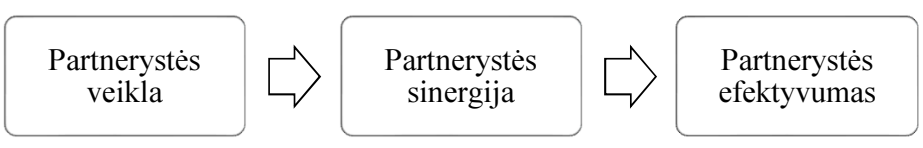

2.1 pav. Sinergija: unikalaus bendradarbiavimo privalumas (Lasker et al. 2001)

Fig. 2.1. Synergy: unique cooperative advantage (Lasker et al. 2001)

Sinergijos vertès modelị aprašè A. Damodaran (2005). Šis modelis skirtas dviejų organizacijų sujungimų vertei ir ịvairių tipų sinergijai tirti. Savo darbe tyrejjas skaičiuoja kapitalo grąžą, kainų ir augimo rinkas. Panašius tyrimus atlieka 
K. R. Harrigan et al. (2017) ir analizuoja inovacijų sinergijos poveiki organizacijos veiklos rezultatams po technologijų įsigijimo. R. Morkvenas (2010) pateikia organizacijos žiniu potencialo sinergijos vertinimo schemą (2.2 pav.), kurioje skaičiuojamas skleidžiamų žinių kiekis tarp darbuotojų ir žinių multiplikatorius.

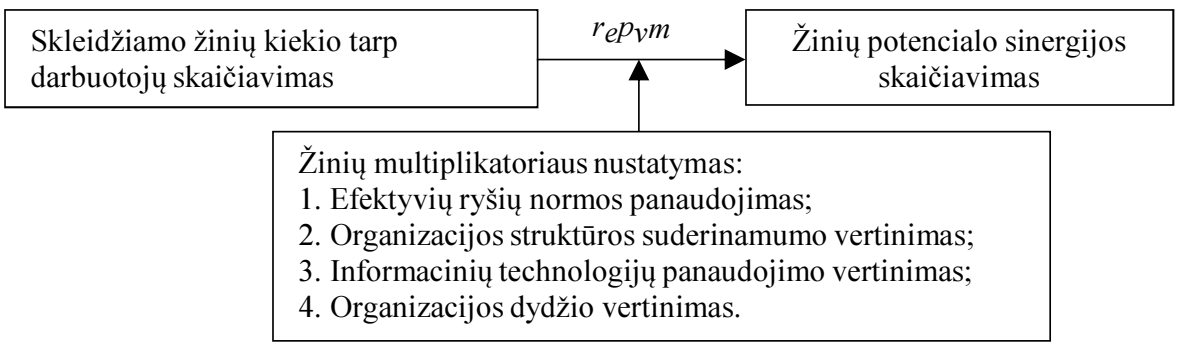

2.2 pav. Organizacijos žinių potencialo sinergijos vertinimo schema (Morkvėnas 2010)

Fig. 2.2. Organisation knowledge potential synergy evaluation scheme (Morkvėnas 2010)

Sinergijos vieta ir tipai parodomi IT portfelio parinkimo modelyje (2.3 pav.), kuri pasiūlè W. Cho et al. (2013). Deja, šis modelis skirtas investavimui ir gali būti taikomas žinių investavimo galimybių analizei organizacijoje.

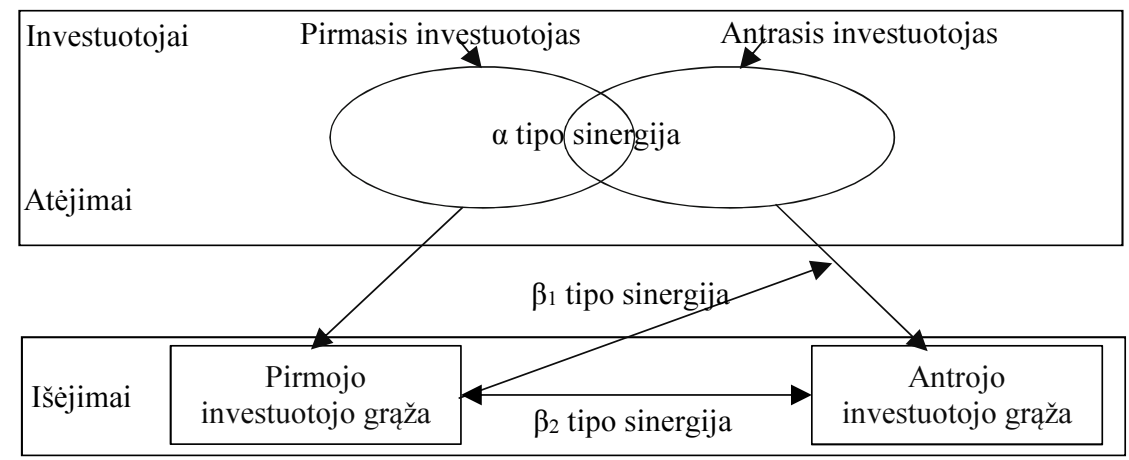

2.3 pav. IT portfelio parinkimo modelis (Cho et al. 2013)

Fig. 2.3. IT portfolio selection model (Cho et al. 2013)

V. Shatrevich et al. (2015) pateikia intelektinio kapitalo dinamini modeli (2.4 pav.), sukonstruotą remiantis A. Osterwalder (2004) verslo valdymo modeliu. Intelektinio kapitalo dinaminiame modelyje minimas ryšių kapitalas, tačiau žinių sinergijos jame neatspindèta. 


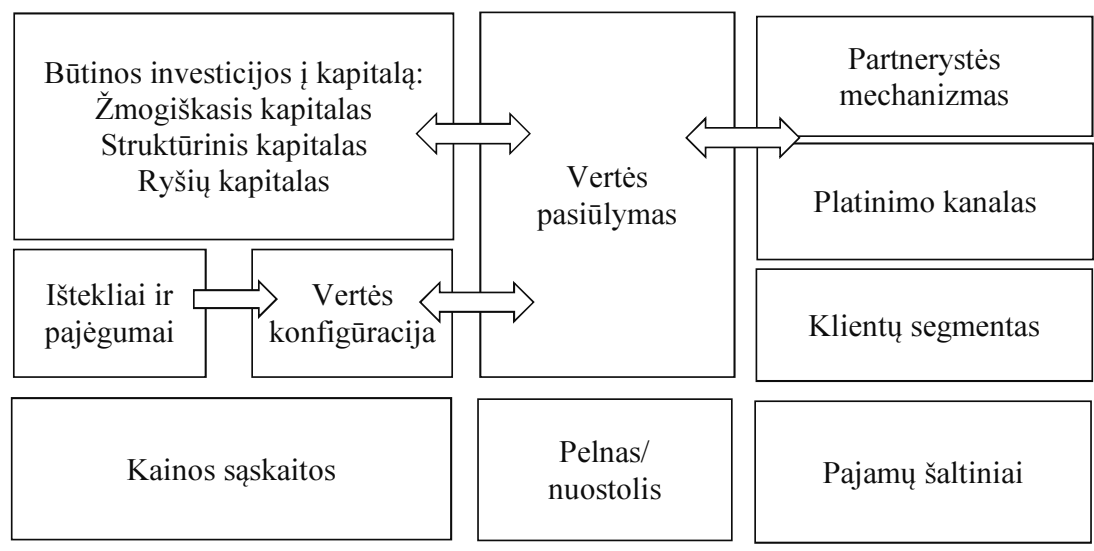

2.4 pav. Intelektinio kapitalo dinaminis modelis (Shatrevich et al. 2015)

Fig. 2.4. Dynamic intellectual capital model (Shatrevich et al. 2015)

J. Barata, P. R. Cunha (2015) nagrinèdami informacinių sistemų ir kiekybės valdymo modelių sąveiką bei aprašydami tolesnių tyrimų žemėlapi išskiria dviejų tipu - kūrimo (angl. design time) ir veikimo (angl. run time) - sinergiją ir nurodo vietą jame. Tačiau, autoriai sinergijos išsamių tyrimų nepateikia.

Atliekant inovacijų sistemos tyrimus Z. Z. Tu et al. (2016) išskiria šešias žinių sinergijos komponentų grupes: žinių igijimo ir atstovavimo igūdžiai, žinių kaupimo ir perdavimo veiksmingumas, pasikeitimo laipsnis ir žinių pasidalijimas, naujų žinių kūrimo ir taikymo lygis, žinių ir technologijų mainų galimybès, naujų paraiškų atsiliepimai ir tobulinimo efektyvumas. Tačiau, komponentų dedamujų turinio nepateikia. Pažymètina, kad žinių sinergijai modeliuoti galima naudoti žinių valdymo modelius: G. Von Krogh, J. Roos (1994) organizacinès epistemologijos modelį, I. Nonaka ir H. Takeuchi (1995) žinių spiralini modeli, C. W. Choo (1998) žinių valdymo kuriant prasmę modeli, K. M. Wiig (1999) žinių kūrimo ir naudojimo modelį, M. Boisot (1998) I-erdvès žinių valdymo modelį.

Taigi, norint apskaičiuoti žinių sinergiją būtina išskirti ir apibrěžti žinių sinergijos komponentus, tai sudarytų sąlygas žinių sinergijos vertinimo modelio sukūrimui.

\section{2. Žinių sinergijos komponentai}

Organizacijos darbuotojai dalindamiesi žiniomis sudaro prielaidas formuotis sinergijai, o remiantis pateiktu žinių sinergijos apibrěžimu galima išskirti 
pagrindinius komponentus, kurie yra darbuotojų išreikštinès, neišreikštinės žinios ir tarpusavio ryšiai (2.5 pav.).

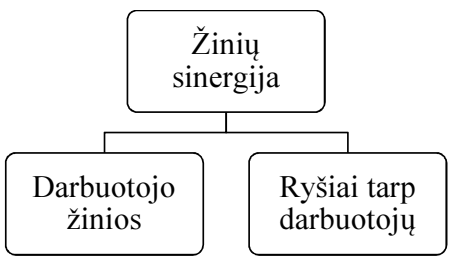

2.5 pav. Žinių sinergijos komponentai (sudaryta autorès)

Fig. 2.5. Knowledge synergy components (compiled by the author)

Svarbus žinių sinergijos komponentas yra darbuotojo žinios. R. Morkvėnas (2010) teigia, kad svarbiausias veiksnys, nuo kurio priklauso organizacijos žinių sinergija, yra aukštos kvalifikacijos darbuotojai, palaikantys vidinius ir išorinius organizacijos ryšius. Kvalifikacija yra igyjama baigus atitinkamas studijas ar išklausius tikslinius kursus, todèl ką tik baigęs studijas asmuo negalès dirbti visu pajègumu, nors labai noriai dalinsis savo žiniomis su kitais darbuotojais, šiuo atveju jam truks patirties.

Išsilavinimas, profesinè patirtis, pareigų lygis, darbuotojo darbo užmokestis, darbo sudètingumas, motyvacija, darbuotojo itaka organizacijos tikslų realizavimui, technologijų panaudojimas, atsakomybè, darbo kultūra, savarankiškumas - tai veiksniai, kurie kuria sinergijos srautus, todell toks teiginys kaip „kvalifikacija yra svarbiausias veiksnys“ kelia abejonių ir reikalauja patikslinimo.

Išsilavinimą, profesinę patirti ir pareigu lygi, kaip svarbius veiksnius, lemiančius darbuotojo žinias, nagrinejja P. Drucker, S. Haynes et al., S. Hori et al., O. Stan, R. K. Kandadi (2.2 lentelè).

Vertinant žinių sinergiją yra labai svarbus informacinių technologijų naudojimo veiksnys, atsižvelgus $\mathfrak{i}$ tai, informacines technologijas galima ịtraukti i žinių sinergijos skaičiavimo formulę ir atlikti eksperimentą reikšmingumo koeficientui apskaičiuoti. Pasak P. Drucker (1993), kuo daugiau technologijų naudojama, tuo didesnès kvalifikacijos specialistų reikia; kuo daugiau žinių naudojama, tuo daugiau jų sukuriama. Siekiant, kad žinios taptų organizacijos pažangos ir gerovès pagrindiniu veiksniu, jomis turi būti efektyviai dalijamasi, tačiau to neįmanoma užtikrinti be informacinių technologijų. Kalbant apie naujų žinių kūrimą reiktų paminèti dar vieną veiksnį, kurio, neišskyrẻ nei vienas mokslininkas - tai kūrybiškumas. Šis veiksnys daro didelę ịtaką naujų žinių kūrimui bei sinerginiams procesams atsirasti ir kurtis sinergijai, todèl jị būtina itraukti vertinant darbuotojo žinias. 
2.2 lentelè. Darbuotojų žinių potencialą lemiančių veiksnių sąrašas (Morkvėnas 2010)

Table 2.2. The list of factors causing employee knowledge potential (Morkvenas 2010)

\begin{tabular}{|c|c|}
\hline Veiksnys & Autoriai (šaltiniai) \\
\hline Išsilavinimas & $\begin{array}{l}\text { Bloom 1956; Herr, Cramer 1984; Cole 1993; Dodgson 1993; } \\
\text { Nonaka 1994; Negroponte 1996; Sveiby 1997; APEC 2000; } \\
\text { Mandelli 2000; Bauman 2002; Pukelis 2002; Stewart, Leopold } \\
\text { 2002; Dahlman 2003; Coulombe et al. 2004; Čiutiené, Sarkiūnaite } \\
\text { 2004; Smith 2004; Šileika et al. 2004; Laužackas et al. 2005; } \\
\text { Žaptorius 2005; Bivainis, Morkvenas 2008; Tech Shelter Group } \\
\text { 2008; World Bank 2008; The Knowledge Company } 2009 .\end{array}$ \\
\hline $\begin{array}{l}\text { Profesinè } \\
\text { patirtis }\end{array}$ & $\begin{array}{l}\text { Schön 1982; Drucker, Cole 1993; Hill, Jones 1993; Dubinas 1995; } \\
\text { Cohen 1998, Hori et al. 2004; Čiutienè, Šarkiūnaite 2004; Smith } \\
\text { 2004; Šileika et al. 2004; Fink 2005; Helms, Cengage 2006; } \\
\text { Žaptorius 2005; Bivainis, Morkvėnas 2008; Workitect 2008; } \\
\text { Haynes, Mickelson 2009, Morkvėnas 2010. }\end{array}$ \\
\hline Pareigų lygis & $\begin{array}{l}\text { Wilensky 1964; Cole 1993; Jovaiša 1993; Dubinas 1995; Šileika } \\
\text { et al. 2004; Žaptorius 2005; Morkvènas } 2010 .\end{array}$ \\
\hline $\begin{array}{l}\text { Darbuotojo } \\
\text { darbo } \\
\text { užmokestis }\end{array}$ & $\begin{array}{l}\text { Cole 1993; Drucker 1993; Dubinas 1995; Stoner et al. 2000; Stan, } \\
\text { Kandadi 2006; Žaptorius 2005; Morkvenas } 2010 .\end{array}$ \\
\hline $\begin{array}{l}\text { Darbo } \\
\text { sudetingumas }\end{array}$ & $\begin{array}{l}\text { Cole 1993; Dubinas 1995; Wissepsmanagement Forum 2003; } \\
\text { Šileika et al. 2004; Johnson 2007; Žaptorius 2005; Bivainis, } \\
\text { Morkvènas 2008. }\end{array}$ \\
\hline Motyvacija & $\begin{array}{l}\text { Cole 1993; Nonaka, Takeuchi 1995; Barth 2000; } \\
\text { Wissepsmanagement Forum 2003; Stan, Kandadi 2006; Johnson } \\
2007 .\end{array}$ \\
\hline $\begin{array}{l}\text { Darbuotojo } \\
\text { itaka } \\
\text { organizacijos } \\
\text { tikslụ } \\
\text { realizavimui }\end{array}$ & $\begin{array}{l}\text { Cole 1993; Dubinas 1995; Barth 2000; Wissepsmanagement Forum } \\
\text { 2003; Workitect 2008; Tech Shelter Group 2008; CV Market } 2009 .\end{array}$ \\
\hline $\begin{array}{l}\text { Technologiju } \\
\text { panaudojimas }\end{array}$ & $\begin{array}{l}\text { Solow 1956; Bell 1973; Agyris 1993; Drucker 1993; Hammer, } \\
\text { Champy 1993; Negroponte 1996; Ives et a. 1997; Levy 1997; } \\
\text { Cairncross 1998; Wiig 1999; APEC 2000; Mandelli 2000; } \\
\text { Benchimol 2001; Prusak 2000; Amidon 2001; Dahlman, 2001; } \\
\text { Wissepsmanagement Forum 2003; Yang, Chen 2007; Johnson } \\
\text { 2007; Gatautis 2008; Melnikas 2008; World Bank 2008; Workitect } \\
\text { 2008; OECD 2008; Pandey, Dutta 2013, Millara, Chenc, Lee } 2016 .\end{array}$ \\
\hline Atsakomybè & $\begin{array}{l}\text { Cole 1993; Dubinas 1995; Wissensmanagement Forum 2003; } \\
\text { Armstrong, Foley 2003; Šileika et al. 2004; Žaptorius } 2005 .\end{array}$ \\
\hline
\end{tabular}


2.2 lentelès pabaiga

\begin{tabular}{|l|l|}
\hline Veiksnys & \multicolumn{1}{|c|}{ Autoriai (šaltiniai) } \\
\hline Darbo kultūra & $\begin{array}{l}\text { Ansoff 1984; Nonaka, Takeuchi 1995; Schein 1997; Wissensmana- } \\
\text { gement forum 2003; Marčinskas et al. 2006; Stan, Kandadi 2006; } \\
\text { Johnson 2007; The Knowledge Company 2009, Pandey, Dutta } \\
\text { 2013, Gonzalez, Martins 2014. }\end{array}$ \\
\hline $\begin{array}{l}\text { Savarankišku- } \\
\text { mas darbe }\end{array}$ & $\begin{array}{l}\text { Cole 1993; Dubinas 1995; Wissensmanagement Forum 2003; } \\
\text { Bornemann, Sammer 2003; Sileika et al. 2004. }\end{array}$ \\
\hline
\end{tabular}

Svarbus antrasis komponentas - tai ryšiai tarp organizacijos narių. Idealioje organizacijoje ryšius tarp darbuotojų vaizduoja pilnasis grafas, kurio kiekviena viršūnè yra tiesiogiai sujungta su kiekviena kita viršūne. Pilnojo grafo briaunų skaičius (ryšių skaičius tarp organizacijos darbuotojų) apskaičiuojamas taip (Krylovas 2004):

$$
r_{t}=\frac{n(n-1)}{2},
$$

čia $r_{t}$ - teorinis ryšių tarp darbuotojų skaičius, $n$-darbuotojų skaičius. Pagal (2.1) formulę skaičiuojami visi ryšiai tarp darbuotojų idealiu atveju. V. A. Graičiūnas (1937) pateikia formulę vadovo ir pavaldinių ryšių apskaičiavimui:

$$
R_{y}=N \cdot\left(\frac{2^{N}}{2}+(N-1)\right),
$$

čia $R_{y}$ - ryšių skaičius, $N$ - pavaldinių skaičius. Mokslinèje literatūroje teigiama, kad darbuotojas efektyviai gali palaikyti 4-6 ryšius, ir šis skaičius laikomas norma, nes pavaldinių skaičiui didejjant aritmetine progresija, ryšių skaičiaus ivertis didejja geometrine progresija (2.6 pav.).

Ryšiams skaičiuoti kai kurie autoriai naudoja sąvoką „tinklų tankumas “, kuri susijusi su darbo grupių efektyvumu ir rezultatyvumu. Pavyzdžiui, R. E. Reagans, E. W. Zuckerman (2001) nustate, kad organizaciniams vienetams, kuriuose pasireiškia tankesni tinklai, būdingas aukštesnis produktyvumas. Kitame tyrime R. E. Reagans et al. (2004) ịrodè, kad tie organizaciniai vienetai, kuriems būdingi tankesni vidiniai tinklai ir kurie turejjo daugiau išorinių ryšių su kitais organizaciniais vienetais, projektus užbaigdavo greičiau. Tinklo tankumas - tai faktinio ryšio tarp dalyvių skaičiaus ir maksimalaus ryšių skaičiaus santykis.

$$
T_{T}=\frac{R_{f}}{r_{\max }}
$$

čia $T_{T}$ - tinklo tankumas, $R_{f}$ - faktinis ryšių skaičius, $r_{\max }$ - maksimalus ryšių tarp darbuotojų skaičius. 


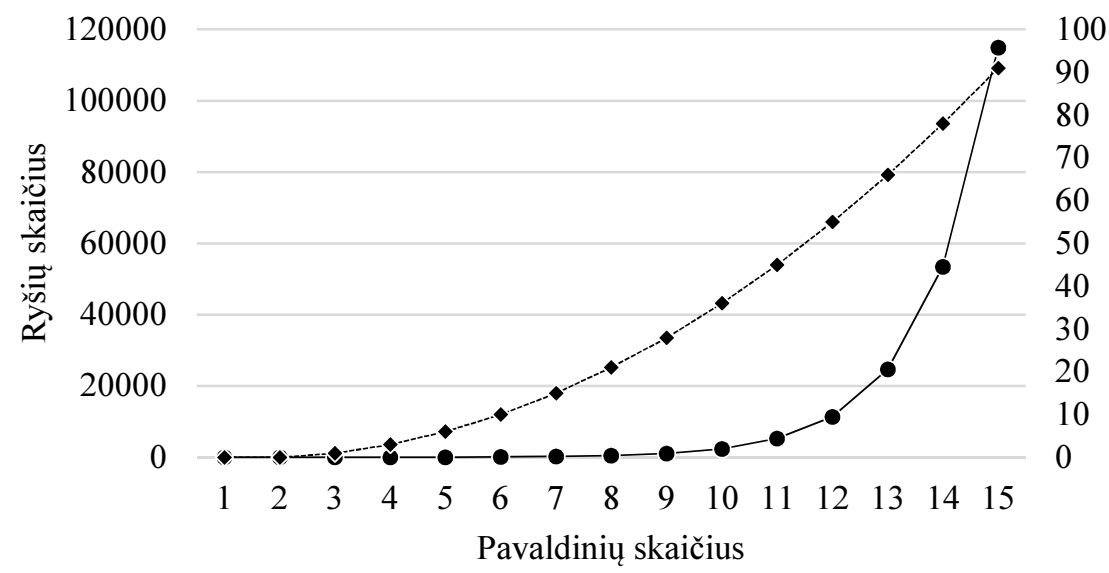

—- Graičiūno formulès ịverčiai ----•---.-Grafų teorijos formulès ịverčiai

2.6 pav. Pavaldinių skaičiaus priklausomybè nuo ryšių (sudaryta autorès)

Fig. 2.6. Dependency of the number of subordinates on relations (compiled by the author)

Norint apskaičiuoti efektyvius ryšius tarp darbuotojų ir organizacijos padalinių, būtina taikyti teorinių normų arba organizacijos struktūrų analize grịstus metodus. Tikslios ryšių tarp darbuotojų skaitinès išraiškos bus pateiktos tolesniuose skyriuose, išnagrinèjus žinių sinergijos tipus.

\section{3. Žinių sinergijos tipai (pagal ryšius)}

Jeigu darbuotojai turi ryšius, bet nesidalija žiniomis gali nesusidaryti sinergija, bet jeigu darbuotojai dalijasi žiniomis ir jas naudoja savo darbe, akivaizdu, jog atsiranda sinergija. Organizacijoje dauguma darbuotojų turi geras sąlygas aktyviai reikšti savo nuomonę, kurti ir skleisti žinias.

Ryšiai tarp darbuotojų galimi, kai vienas darbuotojas dalijasi žiniomis su kitu darbuotoju (vienas su vienu), kai vienas darbuotojas dalijasi žiniomis su grupe darbuotojų (vienas su daug), kai grupè darbuotojų dalijasi žiniomis su grupe darbuotojų (daug su daug) (2.7 pav.).

Priklausomai nuo to, kaip vyksta žinių dalijimasis, susiformuoja tam tikri sinergijos tipai (2.3 lentelè). 


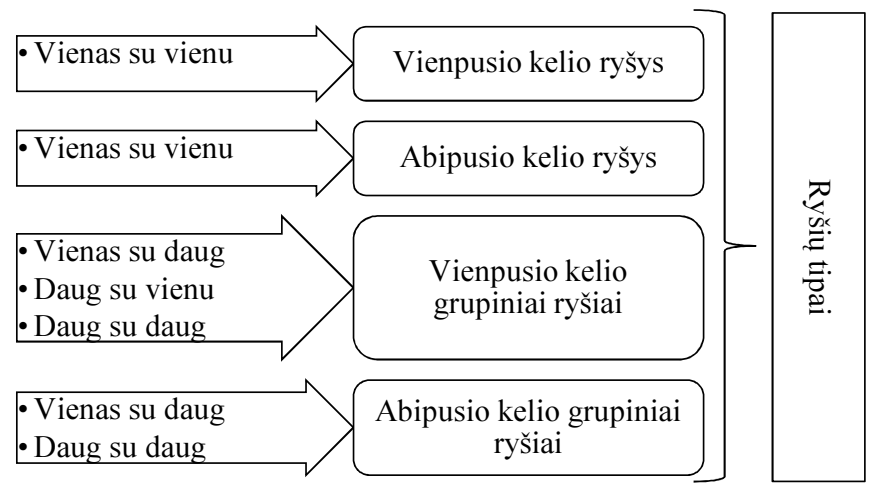

2.7 pav. Ryšių tipai tarp organizacijos darbuotojų (sudaryta autorès)

Fig. 2.7. Types of communication among organisation employees

(compiled by the author)

2.3 lentelè. Žinių sinergijos tipai (sudaryta autorès)

Table 2.3. Knowledge synergy types (compiled by the author)

\begin{tabular}{|c|c|c|c|c|}
\hline \multirow{2}{*}{$\begin{array}{c}\text { Sinergijos } \\
\text { tipai }\end{array}$} & \multirow[b]{2}{*}{ Ryšio tipas } & \multirow[b]{2}{*}{ Aprašymas } & \multicolumn{2}{|c|}{ Pavyzdžiai } \\
\hline & & & $\begin{array}{l}\text { be investiciju i } \\
\text { žinių didinimą }\end{array}$ & $\begin{array}{l}\text { su investicijomis i } \\
\text { žinių didinimą }\end{array}$ \\
\hline \multirow[t]{2}{*}{$\begin{array}{l}\text { Teigiama } \\
\text { sinergija }\end{array}$} & $\begin{array}{l}\text { Vienpusio } \\
\text { kelio ryšys }\end{array}$ & $\begin{array}{l}\text { Vienas } \\
\text { darbuotojas } \\
\text { dalijasi } \\
\text { žiniomis su } \\
\text { kitu } \\
\text { darbuotoju }\end{array}$ & $\begin{array}{l}\text { Organizacijos } \\
\text { rezultatai } \\
\text { pagerėja } \\
\text { atsitiktinèje } \\
\text { veiklos srityje }\end{array}$ & $\begin{array}{l}\text { Organizacija kai kada } \\
\text { investuoja i } \\
\text { darbuotojų mokymus. } \\
\text { Rezultatai geresni nei } \\
\text { buvo prieš mokymus, } \\
\text { pagerėjimas } \\
\text { jaučiamas vienoje } \\
\text { srityje, bet veliau gali } \\
\text { prastėti. }\end{array}$ \\
\hline & $\begin{array}{l}\text { Abipusio } \\
\text { kelio ryšys }\end{array}$ & $\begin{array}{l}\text { Abu } \\
\text { darbuotojai } \\
\text { dalijasi } \\
\text { žiniomis }\end{array}$ & $\begin{array}{l}\text { Organizacijos } \\
\text { rezultatai } \\
\text { pagerèja } \\
\text { atsitiktinèje } \\
\text { veiklos srityje }\end{array}$ & $\begin{array}{l}\text { Organizacija esant } \\
\text { poreikiui skiria lěšų } \\
\text { darbuotoju } \\
\text { mokymams ir } \\
\text { rezultatai geresni nei } \\
\text { buvo prieš mokymus, } \\
\text { pagerèja atsitiktinè } \\
\text { veiklos sritis, } \\
\text { darbuotojai dirba } \\
\text { efektyviau. }\end{array}$ \\
\hline
\end{tabular}


2.3 lentelès pabaiga

\begin{tabular}{|c|c|c|c|c|}
\hline \multirow{2}{*}{$\begin{array}{l}\text { Sinergijos } \\
\text { tipai }\end{array}$} & \multirow[b]{2}{*}{ Ryšio tipas } & \multirow[b]{2}{*}{ Aprašymas } & \multicolumn{2}{|c|}{ Pavyzdžiai } \\
\hline & & & $\begin{array}{l}\text { be investicijų i } \\
\text { žinių didinimą }\end{array}$ & $\begin{array}{l}\text { su investicijomis i } \\
\text { žinių didinimą }\end{array}$ \\
\hline \multirow[t]{3}{*}{$\begin{array}{l}\text { Teigiama } \\
\text { sudètinga } \\
\text { sinergija }\end{array}$} & $\begin{array}{l}\text { Vienpusio } \\
\text { kelio } \\
\text { grupiniai } \\
\text { ryšiai }\end{array}$ & $\begin{array}{l}\text { Vienas } \\
\text { darbuotojas } \\
\text { dalijasi } \\
\text { žiniomis su } \\
\text { grupe } \\
\text { darbuotojų }\end{array}$ & $\begin{array}{l}\text { Organizacijos } \\
\text { rezultatai } \\
\text { pagerèja vienoje } \\
\text { veiklos srityje }\end{array}$ & $\begin{array}{l}\text { Organizacija } \\
\text { investuoja i tam } \\
\text { tikros srities } \\
\text { darbuotojų mokymus. } \\
\text { Rezultatai geresni nei } \\
\text { buvo prieš mokymus, } \\
\text { pagerėja } \\
\text { investuojamos } \\
\text { veiklos sritis, } \\
\text { darbuotojai dirba } \\
\text { efektyviau. }\end{array}$ \\
\hline & $\begin{array}{l}\text { Abipusio } \\
\text { kelio } \\
\text { grupiniai } \\
\text { ryšiai }\end{array}$ & $\begin{array}{l}\text { Vienas } \\
\text { darbuotojas } \\
\text { dalijasi } \\
\text { žiniomis su } \\
\text { grupe } \\
\text { darbuotojų }\end{array}$ & $\begin{array}{l}\text { Organizacijos } \\
\text { rezultatai } \\
\text { pagerèja keliose } \\
\text { veiklos srityse }\end{array}$ & $\begin{array}{l}\text { Organizacija nuolatos } \\
\text { investuoja ị tam tikrų } \\
\text { sričių darbuotojų } \\
\text { mokymus. Rezultatai } \\
\text { geresni nei buvo prieš } \\
\text { mokymus, pagereja } \\
\text { kelios veiklos sritys, } \\
\text { darbuotojai dirba } \\
\text { efektyviai. }\end{array}$ \\
\hline & $\begin{array}{l}\text { Abipusio } \\
\text { kelio } \\
\text { tarpgrupiniai } \\
\text { ryšiai }\end{array}$ & $\begin{array}{l}\text { Du ir } \\
\text { daugiau } \\
\text { darbuotojų } \\
\text { dalijasi } \\
\text { žiniomis su } \\
\text { grupe } \\
\text { darbuotojų }\end{array}$ & $\begin{array}{l}\text { Organizacijos } \\
\text { rezultatai } \\
\text { pagerëja visose } \\
\text { veiklos srityse }\end{array}$ & $\begin{array}{l}\text { Organizacija nuolatos } \\
\text { investuoja ì visu } \\
\text { darbuotojų mokymus. } \\
\text { Rezultatai geresni nei } \\
\text { buvo prieš mokymus, } \\
\text { pagerejja visos veiklos } \\
\text { sritys, darbuotojai } \\
\text { dirba efektyviai. }\end{array}$ \\
\hline
\end{tabular}

Sinergijos stiprumas priklauso nuo ryšio stiprumo ir to, kaip darbuotojai dalijasi žiniomis (2.8 pav.). Jeigu darbuotojas dalijasi žiniomis, bet negauna grižtamojo ryšio iš kito darbuotojo arba darbuotojų grupès, sinergijos stiprumas bus silpnas. Jeigu darbuotojai dalijasi žiniomis tarpusavyje ir pasitiki vieni kitais, sinergijos stiprumas bus maksimalus. 


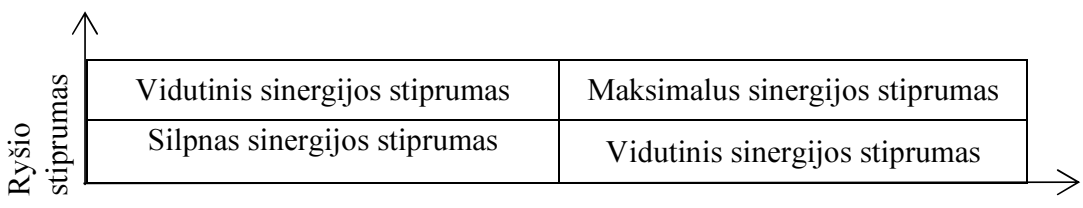

Darbuotojų dalijimasis žiniomis

2.8 pav. Sinergijos stiprumo priklausomybè nuo ryšio stiprumo ir darbuotojų dalijimasis žiniomis (sudaryta autorès)

Fig. 2.8. Synergy strength depends on relation intensity and shared knowledge among employees (compiled by the author)

Apibendrinant galima teigti, kad 2.3 lenteleje išvardinti sinergijos tipai sudaro prielaidas žinių sinergijos modeliavimui, o siekiant vertinti organizacijos darbuotojų žinių sinergiją, būtina įtraukti žinių komponentus: darbuotojo žinias ir ryšius tarp darbuotojų. Šių dedamujų įtraukimas leidžia objektyviai įvertinti organizacijos žinių sinergiją.

\subsection{Siūlymai žinių sinergijos vertinimui}

Išnagrinejjus sinergijos vertinimo metodus ir modelius (poskyris 2.1) bei jų skaičiavimo sudètingumą, išanalizavus žinių sinergijos turinį ir identifikavus žinių sinergijos komponentus bei išskyrus žinių sinergijos tipus (poskyriai 2.2 ir 2.3), žinių sinergijai vertinti siūloma konstruoti tokią formulę, kurią sudarytų du sinergijos komponentai - darbuotojo žinios ir ryšiai tarp darbuotojų. Šių dedamujų ịtraukimas ị žinių sinergijos skaičiavimą leidžia racionaliai ịvertinti sinergiją organizacijoje ir sudaro sąlygas vienareikšmiškam organizacijos darbuotojų žinių sinergijos skaičiavimui (2.9 pav.).

\begin{tabular}{|c|c|c|c|c|c|}
\hline \multicolumn{6}{|c|}{ Žinių sinergija } \\
\hline \multicolumn{4}{|c|}{ Ryšiai tarp darbuotojų } & \multicolumn{2}{|c|}{ Darbuotojo žinios } \\
\hline $\begin{array}{l}\text { Vienpusio } \\
\text { kelio ryšys }\end{array}$ & $\begin{array}{l}\text { Abipusio } \\
\text { kelio ryšys }\end{array}$ & $\begin{array}{l}\text { Vienpusio } \\
\text { kelio } \\
\text { grupiniai } \\
\text { ryšiai }\end{array}$ & $\begin{array}{c}\text { Abipusio } \\
\text { kelio } \\
\text { grupiniai } \\
\text { ryšiai }\end{array}$ & $\begin{array}{l}\text { Išreikštinès } \\
\text { žinios }\end{array}$ & $\begin{array}{c}\text { Neišreikšti- } \\
\text { nès žinios }\end{array}$ \\
\hline
\end{tabular}

2.9 pav. Žinių sinergijos turinio schema (sudaryta autorès)

Fig. 2.9. Knowledge synergy content scheme (compiled by the author)

Darbuotojai, palaikydami vienpusio kelio ryšius, dalijasi ir išreikštinemis, ir neišreikštinèmis žiniomis, taip pat šiomis žiniomis dalijasi ir esant ir kitų tipų 
ryšiams. Ryšių tipus galima pažymèti tokiu dedamujų rinkiniu: $X=\left\{x_{1}, x_{2}, x_{3}, x_{4}\right\}$, o darbuotojo žinias - tokiu: $Y=\left\{\mathrm{y}_{1}, \mathrm{y}_{2}\right\}$. Tada žinių sinergijos veiksnių dedamujų rinkinys bus: $\left\{\mathrm{x}_{1} \mathrm{y}_{1}, \mathrm{x}_{2} \mathrm{y}_{1}, \mathrm{x}_{3} \mathrm{y}_{1}, \mathrm{x}_{4} \mathrm{y}_{1}, \mathrm{x}_{1} \mathrm{y}_{2}, \mathrm{x}_{2} \mathrm{y}_{2}, \mathrm{x}_{3} \mathrm{y}_{2}, \mathrm{x}_{4} \mathrm{y}_{2}\right\}$. Žiniu sinergijos dedamujų rinkinị sugrupavus ir atlikus aritmetinius veiksmus gaunama:

$$
\begin{aligned}
& X+Y=x_{1} y_{1}+x_{2} y_{1}+x_{3} y_{1}+x_{4} y_{1}+x_{1} y_{2}+x_{2} y_{2}+x_{3} y_{2}+x_{4} y_{2}=y_{1}\left(x_{1}+x_{2}+\right. \\
& \left.x_{3}+x_{4}\right)+y_{2}\left(x_{1}+x_{2}+x_{3}+x_{4}\right)=\left(y_{1}+y_{2}\right)\left(x_{1}+x_{2}+x_{3}+x_{4}\right) .
\end{aligned}
$$

Toks veiksnių rinkinio pasiskirstymas įrodo žinių multiplikavimo savybę, t. y. žinios multiplikuoja tiek kartų kiek to nori žmogus. Todèl išgryninus žinių sinergijos komponentus, veiksnių rinkinius, išanalizavus žinių sinergijos vertinimo metodinę bazę, siūloma žinių sinergijos skaičiavimui taikyti tokią formulę:

$$
S_{\check{z}}=R \cdot \hat{Z},
$$

čia $S_{z}$ - žinių sinergija; $R$ - ryšiai tarp darbuotojų; $\hat{Z}$ - darbuotojo žinios.

\subsection{1. Žiniụ sinergijos komponento - ryšių tarp darbuotojų - vertinimo galimybès}

Efektyvių ryšių tarp organizacijos darbuotojų skaičiaus nustatymui yra sukurti teorinemis normomis ir organizacijos struktūrų analize grịsti metodai. Pirmasis metodas pagristas vadybos teorijos normomis, o visi skaičiavimai atliekami darant tokią prielaidą: organizacijos veikla bus organizuojama padalinių pagrindu. Organizacijos struktūru grịsto metodo esmé yra detali organizacijos valdymo struktūros analizè, nustatanti esamus padalinio darbuotojų ryšius ir ryšius tarp skirtingų padalinių darbuotojų.

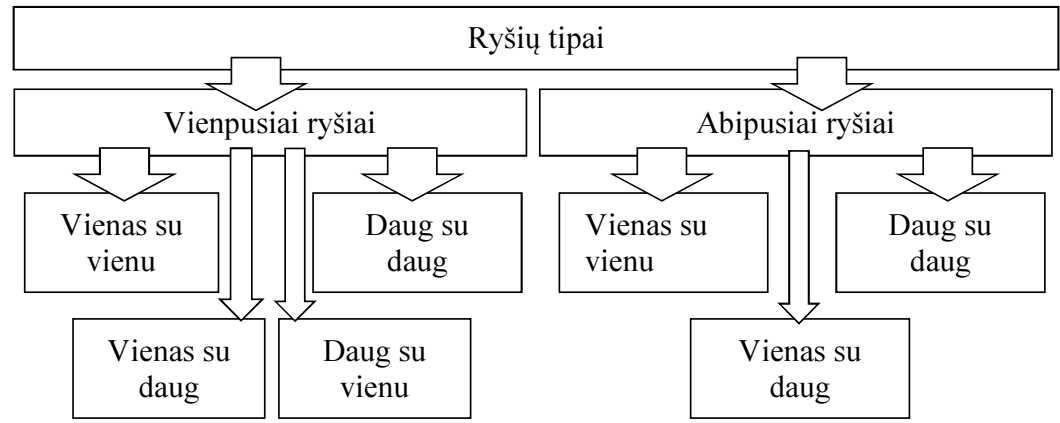

2.10 pav. Ryšių tipų schema (sudaryta autorès)

Fig. 2.10. Scheme of relation types (compiled by the author) 
Atsižvelgiant ị ryšių tipus (2.10 pav.) ir efektyvių ryšių skaičiavimo metodus skirtingo tipo žinių sinergijai skaičiuoti taikytina atitinkama formulè (2.4 lentelè).

2.4 lentelè. Formulès pagal sinergijos ir ryšių tipus (sudaryta autorès)

Table 2.4. Formulas according to synergy and relation types (compiled by the author)

\begin{tabular}{|c|c|c|}
\hline \multicolumn{3}{|c|}{ Teigiama sinergija } \\
\hline $\begin{array}{l}\text { Ryšio } \\
\text { tipas }\end{array}$ & $\begin{array}{l}\text { Vienpusio kelio ryšys (vienas su } \\
\text { vienu) }\end{array}$ & $\begin{array}{l}\text { Abipusio kelio ryšys (vienas su } \\
\text { vienu) }\end{array}$ \\
\hline Formulè & $r_{1 \rightarrow 1}=n$ & $r_{1 \rightarrow 1}=2 n$ \\
\hline \multicolumn{3}{|c|}{ Teigiama sudètinga sinergija } \\
\hline $\begin{array}{l}\text { Ryšio } \\
\text { tipas }\end{array}$ & $\begin{array}{l}\text { Vienpusio kelio grupiniai ryšiai } \\
\text { (vienas su daug, daug su vienu) }\end{array}$ & $\begin{array}{l}\text { Abipusio kelio grupiniai ryšiai } \\
\text { (vienas su daug, daug su vienu) }\end{array}$ \\
\hline Formulè & $r_{1 \rightarrow \infty}=\frac{n(n+1)}{2}$ & $r_{1 \leftrightarrow \infty}=n(n+1)$ \\
\hline $\begin{array}{l}\text { Ryšio } \\
\text { tipas }\end{array}$ & $\begin{array}{l}\text { Vienpusio kelio grupiniai ryšiai } \\
\text { (daug su daug) }\end{array}$ & $\begin{array}{l}\text { Abipusio kelio grupiniai ryšiai (daug } \\
\text { su daug) }\end{array}$ \\
\hline Formulè & $r_{\infty \rightarrow \infty}=\left(2^{n}-1\right)$ & $r_{\infty \leftrightarrow \infty}=2\left(2^{n}-1\right)$ \\
\hline
\end{tabular}

Čia $r$-ryšiai, $n$ - grupès narių skaičius.

Pateiktas siūlymas turi privalumų, kadangi asmens ir grupès ryšiams skaičiuoti taikoma organizacijos struktūrų analize grịstas metodas, o pavienių darbuotojų ryšių skaičiavimui taikomas vadybos teorijos normomis gristas metodas. Toks ryšių išskyrimas bei struktūrų analize ir vadybos teorijos normomis grịstų metodų taikymas sudaro prielaidas visapusiškai įvertinti žinių sinergijos komponentą - ryšius tarp darbuotojų.

Galutiniai ryšiai apskaičiuojami pagal 2.6 formulę:

$$
R=\frac{d_{\max }}{\sum_{j=1} r_{j}}
$$

čia $R$ - galutinis ryšiu skaičius, $r$ - ryšiai, $j$ - ryšių tipų skaičius, $d_{\max }-$ organizacijos darbuotojų skaičius. Galutiniams ryšiams apskaičiuoti siūloma formule sudaro sąlygas eliminuoti didelių organizacijų darbuotojų ryšių skaičių, nes dideleje organizacijoje tarp darbuotojų susidaro didelis ryšiu skaičius. Ryšių tarp darbuotojų tyrèjai A. Graičiūnas (1937), L. Urwick (1943), H. A. Simon (1947), M. Newman et al. (2006), M. Bianchi (2010) nurodo, kad ryšiu, kuriuos efektyviai gali užmegzti darbuotojas, skaičius yra ribotas, nes jų užmezgus daug, dalis ryšių paprasčiausiai tampa neveiksnūs. 


\subsection{2. Žinių sinergijos komponento - darbuotojo žinių - vertinimo problemos ir jų sprendimo galimybès}

Šiuolaikinejje dinamiškoje visuomenejje vienas svarbiausių organizacijos ilgalaikio konkurencinio pranašumo šaltinių yra sukurtas žinių potencialas arba sugebejjimas nuolat kurti veiklai būtinas naujas žinias (Morkvėnas, 2010). I. Nonaka (1994) teigimu, žinias kuriantys darbuotojai yra pagrindinis organizacijos veiklos stimulas. Ilgalaikio konkurencinio pranašumo ir pelningumo šaltinis yra organizacijose naudojamos žinios (Desauza 2003). Žinios gali būti sukurtos ir kaupiamos mokantis, atliekant mokslinius tyrimus, pritaikant jas praktiškai ar pritraukiant naujus darbuotojus, todèl atsiranda galimybè žinias pritaikyti prekiu gamybai, įtraukti jas ị strategini planavimą ir pan. B. Urban, G. C. D. S. Joubert (2017) teigia, jog žmogiškieji ištekliai yra labai svarbus veiksnys tiriant bei vertinant žinias, o nuoseklus ir nuolatinis žinių dalijimasis turi būti naudojamas organizacijose. Mokslininkų teigimu, žinios, kaip tyrimo objektas, organizacijoms idomios tada, kai jos panaudojamos organizacijos tikslams siekti. Pastaruoju atveju ir atsiranda poreikis valdyti, o tuo labiau vertinti tiek organizacijos, tiek darbuotojo žinias.

Darbuotoju žinioms organizacijoje vertinti nèra taikomi visuotinai pripažistami metodai: vienuose tyrimuose organizacijos darbuotojų žinios vertinamos atliekant kompetencijų analizę, kituose - taikant ekspertų vertinimą. N. Moradmand et al. (2014) teigia, kad kuriant žinių vertinimo modelius kaip pagrindą galima naudoti Bloomo/Anderseno taksonomiją (jų pagrindu sukurta ir Lietuvos kvalifikacijų vertinimo sistema). Šioje taksonomijoje lygiams apibūdinti panaudojamos veiklos, kuriai yra pasirengęs atitinkamo lygio kvalifikaciją igijęs asmuo, charakteristikos - veiklos sudetingumas, savarankiškumas ir kintamumas. Lietuvos kvalifikacijų vertinimo sandaroje numatyti dokumentai, kurie liudija asmens pasiekimus tam tikrame lygyje (2.5 lentelè).

Vertinant žinias nèra vieningos nuomonès dèl naudojamų sąvokų (kompetencija, kvalifikacija, igūdžiai, gebejjimai, žinios), o išskiriant veiksnius jie pritaikomi prie konkrečios organizacijos, t. y. standartų trūkumas didina atskirtị tarp vertinimo rezultatų (sunku juos lyginti).

Kompetencijų pagrindu sukurtas JAV konsultacinès įmonès „Workitect Inc.“ (2008) kompetencijų modelis, kuriame esminès kompetencijos skirstomos i tris stambias grupes:

- kompetencijos, reikalingos dirbant su žmonèmis (socialinès kompetencijos);

- verslo kompetencijos;

- asmeninès kompetencijos (savęs valdymo kompetencijos). 
2.5 lentelè. Kvalifikaciją patvirtinantys dokumentai pagal LTKS lygius (sudaryta autorès remiantis Lietuvos kvalifikacijų sandara 2012)

Table 2.5. Documents confirming qualification under Lithuanian Qualifications Framework (LTQF) levels (compiled by the author based on Lithuanian Qualification Framework 2012)

\begin{tabular}{|c|c|c|c|}
\hline $\begin{array}{l}\text { LTKS } \\
\text { lygis }\end{array}$ & Kvalifikacijos darbui & Kvalifikacijos mokymuisi & $\begin{array}{l}\text { LTKS } \\
\text { lygis }\end{array}$ \\
\hline \multirow{2}{*}{8} & \multicolumn{2}{|c|}{ Daktaro diplomas } & \multirow{2}{*}{8} \\
\hline & \multicolumn{2}{|c|}{ Meno licenciato diplomas } & \\
\hline \multirow{2}{*}{7} & \multicolumn{2}{|c|}{ Rezidentūros pažymèjimas } & \multirow{2}{*}{7} \\
\hline & \multicolumn{2}{|c|}{ Magistro diplomas } & \\
\hline \multirow{3}{*}{6} & \multicolumn{2}{|c|}{ Bakalauro diplomas } & \multirow{3}{*}{6} \\
\hline & \multicolumn{2}{|c|}{ Profesinio bakalauro diplomas } & \\
\hline & \multicolumn{2}{|c|}{ Studijų pažymèjimas } & \\
\hline 5 & \multicolumn{2}{|c|}{ Šiuo metu šio lygio kvalifikacijos neteikiamos } & 5 \\
\hline 4 & \multirow{4}{*}{ Kvalifikacijos pažymejjimas } & Brandos atestatas & 4 \\
\hline 3 & & & 3 \\
\hline 2 & & $\begin{array}{l}\text { Pagrindinio išsilavinimo } \\
\text { pažymejjimas }\end{array}$ & 2 \\
\hline 1 & & & 1 \\
\hline
\end{tabular}

„Workitect Inc.“ modelis turi trūkumų, kadangi jis orientuotas i siaurą vertinimo turini, nes vartojama ,kompetencijos“ sąvoka neapima viso turimo darbuotojo žinių turinio.

Žinių vertinimui taikomų kiekybinių metodų šiuolaikiniame moksle trūkumus rodo Innsbruck universiteto mokslininko K. Fink (2005) paskelbtas darbas ,Žinių vertinimas". Šio tyrèjo nuomone, interviu metodas - dažniausiai naudojamas žinioms vertinti. Tyrimo pagrindas - refleksijos teorija, o žinių vertinimo tikslumas užtikrinamas įvertinant apklausèjo įtaką vertinimui. Interviu metodas pasirenkamas norint gauti informaciją apie darbuotojų žinias. Panašaus pobūdžio žinių vertinimo modelis aprašytas M. Park et al. (2010), skirtas statybų sektoriui. Modelyje taikomas ekspertų rodiklis (ER), kuris išreiškia specialistų, ìsisavinančių specifinę informaciją, žinių lygị. Autoriai teigia, kad siūlomas modelis leidžia tiksliai vertinti žinias ir skatinti jas igyti, o taikant ši modeli praktikoje, galima gerinti ịmonès veiklą. Tačiau, taikomas ekspertinis vertinimas kelia abejonių, nes vertinimas priklauso nuo ekspertų tiek profesinių, tiek ir asmeninių savybių.

Y. Huang et al. (2012) analizuoja komandos stabilumą žinių kontekste. Jų sukurtas modelis paremtas algoritminiu skaičiavimu ir logistikos principais įrodo ryši tarp komandos stabilumo ir žinių dalijimosi. 
Tarptautinè įmonè „OD\&M Consulting“ pateikia pareigybių klasifikavimo modelị (angl. Global Professional System, (GPS)). Tai tarptautinè pareigybių klasifikavimo metodika, kurios pagalba profesionaliai išanalizuojamos organizacijos pareigybès ir sukuriama organizacijos pareigybių lygių struktūra. Anot „OD\&M Consulting“, GPS yra efektyvus įrankis organizacijos pareigybių klasifikavimo naudojimui, leidžiantis apibrèžti ryši tarp pareigybès ir veiklos rezultatų bei numatyti galimybes darbuotoju profesiniam tobulejimui bei atlygio kitimui (2.11 pav.). Remiantis vertinimo pagal GPS metodiką metu pateiktomis ižvalgomis galima sèkminga karjeros galimybių analizè ir valdymas, nustatomi elementai skatinantys profesinį tobulejimą. Vis dèlto ir šis metodas neatspindi viso darbuotojo žinių turinio, remiamasi tik pareigybių vertinimu.

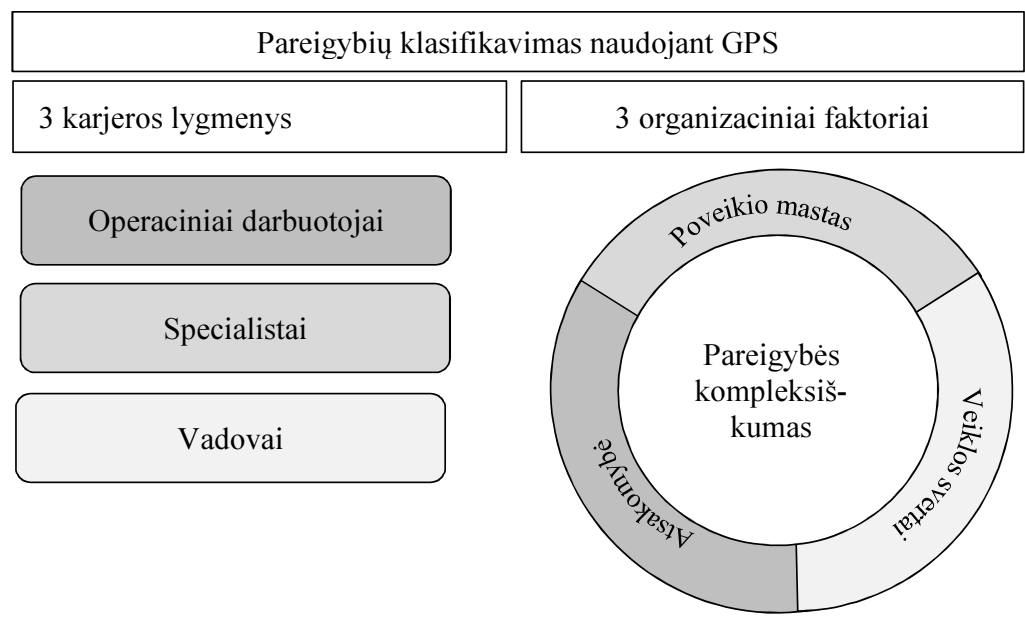

2.11 pav. Pareigybių klasifikavimo modelis (sudaryta OD\&M Consulting)

Fig. 2.11. Job classification model (compiled by OD\&M Consulting)

Dar vieną kompetencijų modelį galima sumodeliuoti interaktyviu būdu tinklapyje (2.12 pav.). Modelio kūrejjai teigia, kad norint išsiaiškinti ir sumodeliuoti sau reikalingą modeli reikia skirti 20 valandų. Modelio hierarchinè kompetencijų struktūra susideda iš trijų dalių: pagrindinių kompetencijų (akademinių kompetencijų, darbo vietos igūdžių), darbui reikalingų žinių (technologinių ir techninių) ir gretutinių (vadybos, specifinių žinių) kompetencijų (DOLETA, 2014).

Mokslininkų darbuose, kaip ir aptartuose pavyzdžiuose, matome pagrindinị trūkumą - nagrinèjami veiksniai ir vertinimo sistemos yra atsietos nuo žmogaus. J. Matošková (2016) atliktame žinių matavimo tyrime nustatè atotrūkị tarp asmens ir sistemos lygmens (mikro) ir organizacinio (makro) lygmens, kuriuos reikètu 
išsamiau analizuoti atliekant papildomus tyrimus. Apibendrinant galima teigti, kad modeliai dažniausiai sukurti nagrinèti duomenų, procesų ir žinių lygmenis, tik darbui atlikti reikalingus ịgūdžius. Išnagrinejjus Towers Watson organizacijos metodiką (Towers Watson...) jau akcentuojamas žmogus, karjeros galimybès, asmens tobulejjimo aspektai.

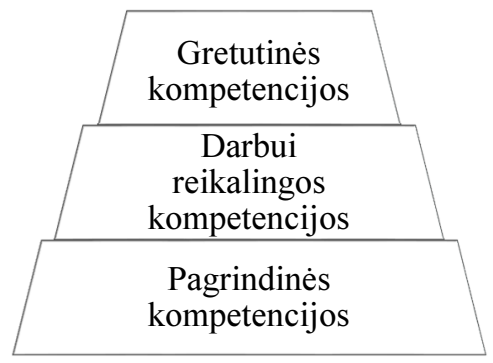

2.12 pav. DOLETA kompetencijų modelis (DOLETA http://www.careeronestop.org/CompetencyModel/) Fig. 2.12. DOLETA competency model (DOLETA http://www.careeronestop.org/CompetencyModel/)

Išsamius organizacijos žinių tyrimus aprašo J. Bivainis ir R. Morkvėnas (2008) akcentuodami pakopiškumą, kuris leidžia gauti išsamesnius rezultatus. Analizuojant organizacijos ir joje dirbančių asmenų kompetenciją, autoriai siūlo tyrimą atlikti vertinant žinių potencialą, tai leistų sukurti labiau standartizuotą modelį bei duotų daugiau galimybių priartinti kuriamus modelius prie realybès. Tyrèjai siūlo skaičiuoti darbuotojo žinių potencialą išskiriant tris veiksnius: išsimokslinimą, profesinę patirti, pareigų lygị. Darbuotojo žinių skaičiavimui taikomas pasvertų normalizuotų reikšmių sumos metodas (angl. Simple Additive Weighting, (SAW)), o veiksnių reikšmingumui nustatyti tyrèjai naudojo ekspertini vertinimą.

Išnagrinejjus ịvairių darbų autorių siūlomus modelius ir metodikas, skirtas darbuotojo žinioms vertinti, labiausiai tinkantis darbuotojų žinių vertinimui yra J. Bivainio ir R. Morkvèno pateiktas metodas. Metodą siūloma pakoreguoti tokiu būdu: veiksnius, turinčius ịtakos darbuotojo žinioms, suskirstyti ị du blokus išreikštines ir neišreikštines žinias; išskirtiems žinių blokams suteikti reikšmingumą, kurị vertins ekspertai. Toks reikšmingumų suteikimas grindžiamas tuo, kad tiek išreikštinès, tiek neišreikštinès žinios darbe vartojamos to paties darbuotojo skirtingomis apimtimis, priklausomai nuo labai ịvairių aplinkybių, todèl suma sumarum bendra jų apimtis gali būti laikoma lygi vienetui. 


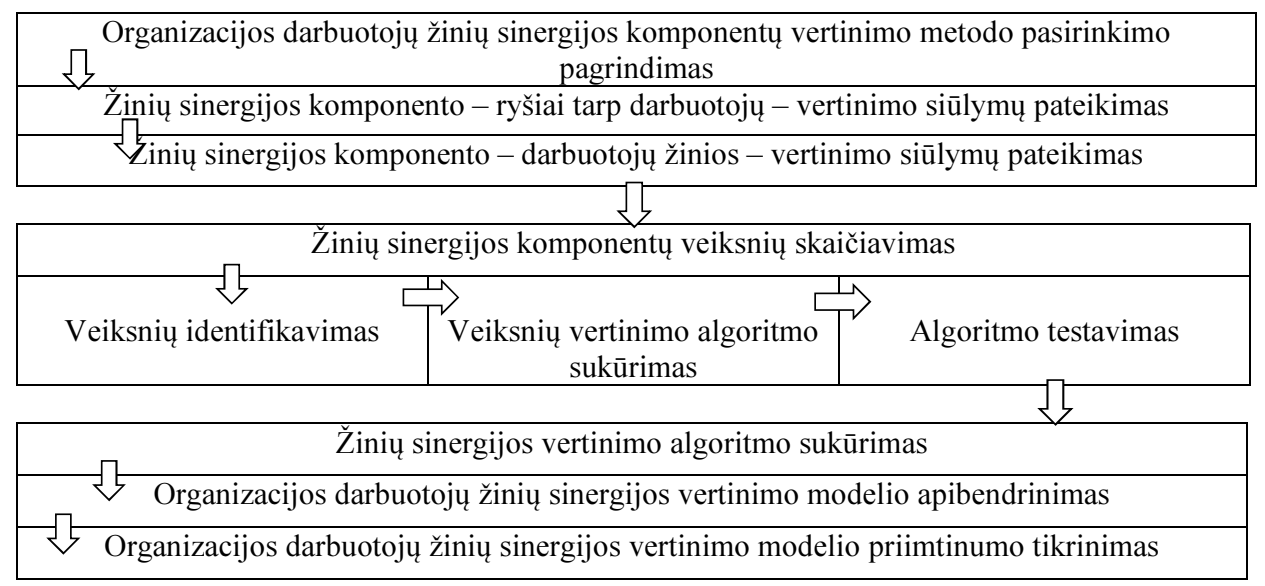

2.13 pav. Organizacijos darbuotojų žinių sinergijos vertinimo tolesnių tyrimų schema (sudaryta autorès)

Fig. 2.13. Creation scheme of organisation employee knowledge synergy evaluation model (compiled by the author)

Vertinimo metodų rinkiniui bei metodikai sudaryta schema, kurią taikant atlikti tolesni žinių sinergijos tyrimai ir vertinta žinių sinergija bei jos komponentai organizacijoje (2.13 pav.).

\subsection{Antrojo skyriaus išvados ir disertacijos uždavinių formulavimas}

1. Atlikta žinių sinergijos vertinimo metodinès bazès analizè leidžia konstatuoti žinių sinergijos vertinimo tyrimų nepakankamą išbaigtumą, kadangi nei viename iš nagrinètų vertinimo metodų bei modelių neatsispindi sinerginiai procesai, juose nèra aiškios dedamujų charakteristikos, o kai kurie iš tyrimų skirti tik tam tikros srities sinergijos nustatymui, todèl numatyti tolesni uždaviniai: sukurti ir pateikti organizacijos darbuotojų žinių sinergijos vertinimo metodų rinkini, sujungiantị vertinamus organizacijos darbuotojų žinių sinergijos komponentus i visumą; parengti organizacijos darbuotojų žinių sinergijos vertinimo metodiką, taikomą įvairiose organizacijose, ir empiriškai patikrinti organizacijos darbuotojų žinių sinergijos vertinimo metodų rinkinio pritaikomumą.

2. Vertinant žinių sinergijos komponentą - ryšius tarp darbuotojų - skaitinès išraiškos nustatymui siūlomi teorinèmis normomis ir organizacijos struktūrų 
analize grịsti metodai. Pirmasis metodas pagristas vadybos teorijos normomis, o visi skaičiavimai atliekami darant tokią prielaidą: organizacijos veikla organizuojama padaliniu pagrindu. Organizacijos struktūrų grịsto metodo esmè yra detali organizacijos valdymo struktūros analizè, nustatanti esamus padalinio darbuotojų ryšius ir ryšius tarp skirtingu padalinių darbuotojų.

3. Žiniu sinergijos komponentui - darbuotojo žinios - vertinti nèra vieningos nuomonès dèl naudojamų sąvokų (kompetencija, kvalifikacija, igūdžiai, gebejjimai, žinios), o išskiriant veiksnius jie pritaikomi prie konkrečios organizacijos, t. y. standartu nebuvimas didina atskirti tarp vertinimo rezultatų (sunku juos lyginti). Mokslininkų darbuose įžvelgiamas pagrindinis trūkumas nagrinejjami veiksniai ir vertinimo sistemos yra atsietos nuo žmogaus. Modeliai dažniausiai sukurti nagrinèti duomenų, procesų ir žinių lygmenis, tik darbui atlikti reikalingus igūdžius. Išnagrinèjus ịvairių darbų autorių siūlomus modelius ir metodikas, skirtas darbuotojo žinioms vertinti, labiausiai tinkantis darbuotojų žinių vertinimui yra J. Bivainio ir R. Morkvèno pateiktas metodas. Metodą siūloma pakoreguoti tokiu būdu: veiksnius, turinčius įtakos darbuotojo žinioms, suskirstyti i du blokus - išreikštines ir neišreikštines žinias; išskirtiems žinių blokams suteikti reikšmingumą, kurị vertins ekspertai.

4. Vertinimo metodų rinkiniui bei metodikai sudaryta schema, kurią taikant atlikti tolesni žinių sinergijos tyrimai ir vertinta žinių sinergija bei jos komponentai organizacijoje. 



\section{Žinių sinergijos vertinimo metodų rinkinys}

Šiame skyriuje pateikti žinių vertinimo veiksniai, jų dedamosios. Organizacijos darbuotojo žinioms vertinti išanalizuotos daugiakriterinių metodų charakteristikos bei pagristas žinių sinergijos komponento - darbuotojo žinios vertinimo metodų pasirinkimo tikslingumas, pagal išskirtus vertinimo metodų kriterijus, t. y. taikymo rezultatai turi būti pastovūs, sąnaudos laiko atžvilgiu mažos, o patys metodai nesunkiai pritaikomi organizacijoje. Be to pateiktos formulès darbuotojo žinioms apskaičiuoti.

Skyriaus tematika paskelbti du autorès straipsniai (Skačkauskienė, Katinienė 2017, Skačkauskienè, Hrušecká, Čepel, Katinienė 2018).

\subsection{Organizacijos darbuotojų žinių sinergijos vertinimo metodai}

Organizacijos žinių sinergijos vertinimo modelis kuriamas daugiakriterinių sprendimų analizės teorijos grịstais principais (Belton, Stewart 2002):

- Tikslingumas: ekspertai-vertintojai turi aiškiai sieti pagrindines atitinkamos srities ekspertinio vertinimo sąvokas su vertinimo tikslu. 
- Suprantamumas: visi vertintojai turi vienodai suprasti apie vertinimo kriterijus.

- Matuojamumas: kriterijai gali būti pamatuojami praktikoje, jie turi būti paaiškinti subkriterijais ir kokybès atitikimo kriterijaus lygiais.

- Nepertekliškumas: negali būti taip, kad viena ir ta pati savybė yra aprašyta keliais skirtingais kriterijais.

- Nepriklausomumas: vertintojai turi vertinti alternatyvas atskirai pagal kiekvieną kriterijų, bet kartu turèti omeny, kad egzistuoja sąryšiai tarp kriterijų, t. y. kriterijai sudaro sistemą.

- Išsamumas: kriterijų neturi būti nei per daug, nei per mažai, kriterijai neturi būti nei per daug stambūs, nei smulkūs - jie turi aprašyti visas pagrindines alternatyvos savybes per daug nesileidžiant i detales, t. y. modelis neturi versti vertintojus vertinti alternatyvų kokybę aklai pagal formalius subkriterijus - vertintojas turi suprasti kriterijaus reikalavimus kaip visumą ir vertinti atitinkamai.

- Optimalumas: modelis turi būti taikytinas praktikoje ir jo taikymas neturi užimti nepagrịstai daug laiko.

- Paprastumas: nežiūrint ị tai, kad kokybès vertinimo problema yra labai sudètinga, modelio kūrejjai turi pateikti vertintojams paprastą ir aiškią kriterijų sistemą.

Žinių sinergijos modelio kriterijų parinkimai susiję su šiais principais, todèl apibendrinant ivvairių autorių siūlomus sinergijos modelius ir vertinimus, konstruojamas modelis susideda iš dviejų komponentų: darbuotojų žinių ir ryšių tarp darbuotojų (3.1 pav.).

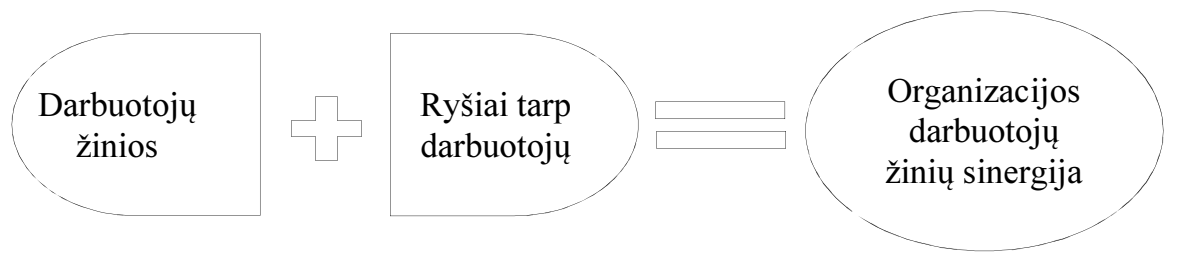

3.1 pav. Organizacijos žinių sinergijos modelis (sudaryta autorès)

Fig. 3.1. Organisation knowledge synergy model (compiled by the author)

Norint įvertinti darbuotojo žinias, tinkamiausia veiksnius suskirstyti i du blokus - išreikštines ir neišreikštines žinias, o šiems žinių blokams suteikti reikšmingumus, t. y. išreikštinių žinių $(\alpha)$ ir neišreikštinių žinių $(\beta)$ reikšmingumo koeficientus. Darbuotojo žinios apskaičiuojamos pagal formulę:

$$
\hat{\mathrm{Z}}=\alpha \sum_{n=1} V I_{n}+\beta \sum_{n=1} V N_{n},
$$


čia $\hat{Z}$ - darbuotojo žinios, $V I_{n}-n$-ojo darbuotojo išreikštinių žinių veiksniai, $V N_{n}-$ $n$-ojo darbuotojo neišreikštinių žinių veiksniai, $n$-darbuotojų skaičius.

Atskiriems veiksniams vertinti apžvelkime keletą vertinimo metodikų. Darbuotojo išreikštinių ir neišreikštinių žinių veiksnių pasirinkimui ir vertinimui taikomi įvairūs metodai. G. A. Cole (1993) pateikè darbo sudètingumo vertinimo kriterijaus (3.1 lentelè). Kai kurie iš jų atspindi darbuotojo asmenini indèli i darbą bei neišreikštų žinių kiekį.

3.1 lentelè. Darbo sudètingumo vertinimo kriterijai (Cole 1993)

Table 3.1. Job complexity evaluation criteria (Cole 1993)

\begin{tabular}{|c|l|c|}
\hline Nr. & \multicolumn{1}{|c|}{ Darbo sudėtingumo kriterijus } & $\begin{array}{c}\text { Kriterijaus itaka (proc.) } \\
\text { vertinant bendrą darbo } \\
\text { sudètingumą }\end{array}$ \\
\hline 1 & Išsilavinimas & 20 \\
\hline 2 & Darbo užduočiu vykdymas laiku & 10 \\
\hline 3 & Darbo patirtis & 10 \\
\hline 4 & $\begin{array}{l}\text { Asmeninė atsakomybė už atliekamą darbą ir } \\
\text { jo kokybę }\end{array}$ & 15 \\
\hline 5 & Dalyvavimas priimant vadybos sprendimus & 15 \\
\hline 6 & Vadovavimas darbo kolektyvui & 15 \\
\hline 7 & Kontaktų intensyvumas įmonèje & 5 \\
\hline 8 & Kontaktų intensyvumas už imonės ribu & 5 \\
\hline 9 & Atsakomybė už informacijos saugojimą & 3 \\
\hline 10 & Darbo sąlygų problemos & 2 \\
\hline Iš viso: & 100 \\
\hline
\end{tabular}

A. Šileika (2004) adaptavo Tarptautinès darbo organizacijos aprobuotą Ženevos schemą ir parengè pareigybių vertinimo metodiką (3.2 lentelè), pagal kurią veiksniai skirstomi ị lygius. Lygių skaičius priklauso nuo konkretaus veiksnio specifikos, galimybės visapusiškiau ir objektyviau atskleisti jo reikšmę. Kiekvieno veiksnio lygis ịvertintas balais, jie išdèstyti pagal svarbą - didejjančia tvarka (pavyzdžiui, „Išsimokslinimo” veiksnys suskirstytas ị septynis lygius, kurių vertę lemia darbo vietos reikalavimai išsimokslinimui; „Profesinès patirties” veiksnys suskirstytas į dešimt lygių, kurių vertę lemia darbo stažo, gebèjimo atlikti ịvairaus sudètingumo darbus, reikalaujančius nuolatinio kvalifikacijos kèlimo, bei sugebejimo spręsti ịvairaus sudetingumo problemas ir t.t. svarba konkrečioje darbo vietoje). Vertinimo metodikos fragmentai gali būti adaptuoti darbuotojo žinių vertinime. 
3.2 lentelè. Darbo užmokesčio vertinimas pagal darbų ir pareigybių vertinimo metodiką (Šileika et al. 2004)

Table 3.2. Salary evaluation according to job and work evaluation methods (Šileika et al. 2004)

\begin{tabular}{|c|l|c|c|}
\hline Nr. & \multicolumn{1}{|c|}{ Veiksniai } & Balai & Proc. \\
\hline 1 & Išsimokslinimas & 75 & 15 \\
\hline 2 & Profesinė patirtis & 70 & 14 \\
\hline 3 & Pareigų ir vadybos lygiai & 50 & 10 \\
\hline 4 & Sprendimų mastas ir veikimo laisvė & 75 & 15 \\
\hline 5 & Savarankiškumas ir kūrybiškumas darbe & 70 & 14 \\
\hline 6 & Atsakomybė & 60 & 12 \\
\hline 7 & Darbo sunkumas & 50 & 10 \\
\hline 8 & Darbo sąlygos & 50 & 10 \\
\hline Iš viso: & 500 & 100 \\
\hline
\end{tabular}

J. Žaptorius (2005) analizuodamas bendruosius pareigybès veiksnius išskyrè darbo veiksnius ir pateikè jų vertinimą balais (3.3 lentelè). Pavyzdžiui, darbo sudètingumas vertinamas atsižvelgiant ị darbuotojo išsilavinimą, profesinę patirtį, sprendimų mastą, vadybos ir pareigų lygius.

3.3 lentelè. Darbo veiksnių vertè (Žaptorius 2005)

Table 3.3. Value of job factors (Žaptorius 2005)

\begin{tabular}{|c|l|c|}
\hline Nr. & \multicolumn{1}{|c|}{ Bendrieji pareigybės veiksniai } & Maksimalus vertinimo balų skaičius \\
\hline 1 & Darbo sudėtingumas & 450 \\
\hline 2 & Socialinè reikšmė & 220 \\
\hline 3 & Atsakomybė & 180 \\
\hline 4 & Darbo sunkumas ir sąlygos & 150 \\
\hline Iš viso: & 1000 \\
\hline
\end{tabular}

R. Morkvėnas (2010), nagrinėdamas darbuotojo žinių potencialą, išskyrè vienuolika veiksnių, tai: profesine patirtis, išsilavinimas, pareigų lygis, darbuotojo darbo užmokestis, darbo sudètingumas, motyvacija, darbuotojo itaka organizacijos tikslų realizavimui, technologijų panaudojimas, atsakomybè, darbo kultūra ir savarankiškumas darbe. Tyrejas teigia, kad visi literatūroje analizuojami veiksniai gali turèti įtakos darbuotojo žinioms, tačiau tik kelių iš jų itaka ypač svarbi, todèl atlikęs eksperimentą ir atsižvelgdamas ị ekspertų vertinimus, išskyré tris svarbiausius veiksnius (3.4 lentelè). 
3.4 lentelè. Darbuotojo žinių potencialo veiksniai (Morkvėnas 2010)

Table 3.4. Factors of employee knowledge potential (Morkvènas 2010)

\begin{tabular}{|c|l|l|}
\hline Nr. & Darbuotojo žinių potencialo veiksniai & Ekspertų vertinimo reikšmingumas \\
\hline 1 & Išsilavinimas & 0,34113 \\
\hline 2 & Profesinė patirtis & 0,54303 \\
\hline 3 & Pareigų lygis & 0,11584 \\
\hline Iš viso: & 1 \\
\hline
\end{tabular}

Pastebètina, kad daugelis nagrinètu autoriu atmeta motyvacijos veiksnį arba jo neitraukia i tyrimus. Visgi, Ž. J. Brčić, K. K. Mihelič (2015) savo tyrime, kuriame demesys yra sutelktas į veiksnius, kurie daro įtaką žiniu pasidalijimui tarp darbuotojų įrodè, kad darbuotojų pasiryžimas ir motyvacija dirbti yra svarbūs.

Kai kurie tyrèjai (Vanagas, Tumènas 2008), nagrinèdami statutinių pareigūnų vertinimą, siūlo taikyti skirtingus veiklos vertinimo kriterijus vadovams ir kitiems darbuotojams. Vadovų veiklos vertinimo kriterijai yra organizacijos strateginiu tikslų igyvendinimas, vadovavimas, lyderiavimas, o darbuotojų veiklos vertinimo kriterijai yra produktyvumas, kompetencija, veiklos kokybè (3.5 lentelè).

3.5 lentelė. Veiklos vertinimo kriterijai (sudaryta autorés pagal Vanagą, Tumėną 2008)

Table 3.5. Activity evaluation criteria (compiled by the author based on Vanagas, Tumėnas 2008)

\begin{tabular}{|c|c|c|c|}
\hline \multicolumn{4}{|c|}{ Vadovų veiklos vertinimo kriterijai } \\
\hline Kriterijai & $\begin{array}{l}\text { Organizacijos } \\
\text { strateginių tikslų } \\
\text { igyvendinimas }\end{array}$ & Vadovavimas & Lyderiavimas \\
\hline 胥 & $\begin{array}{l}\text { Istaigos vizijos, } \\
\text { misijos, tikslų ir } \\
\text { uždavinių bei vertybių } \\
\text { suvokimas, prioritetų } \\
\text { nustatymas; } \\
\text { Istaigos strateginio } \\
\text { veiklos plano rengimo } \\
\text { ir igyvendinimo } \\
\text { organizavimas ir } \\
\text { koordinavimas; } \\
\text { Informacijos, susijusios } \\
\text { su istaigos veikla, } \\
\text { valdymas (jos } \\
\text { rinkimas, apdorojimas } \\
\text { ir analizè, išvadụ } \\
\text { formulavimas, }\end{array}$ & $\begin{array}{l}\text { Personalo valdymas; } \\
\text { Finansinių ištekliụ } \\
\text { valdymas; Materialinių } \\
\text { ištekliu valdymas; } \\
\text { Technologijų valdymas }\end{array}$ & $\begin{array}{l}\text { Efektyvaus } \\
\text { bendravimo ir } \\
\text { bendradarbiavimo } \\
\text { istaigoje } \\
\text { užtikrinimas, } \\
\text { tarpinstitucinio } \\
\text { bendradarbiavimo } \\
\text { skatinimas; } \\
\text { Orientavimasis i } \\
\text { rezultatus, ịtaka } \\
\text { pavaldinių elgesiui } \\
\text { ir mąstymui; } \\
\text { Procesų ir pokyčiu } \\
\text { valdymas (procesu } \\
\text { nustatymas, } \\
\text { valdymas ir }\end{array}$ \\
\hline
\end{tabular}


3.5 lentelès pabaiga

\begin{tabular}{|c|c|c|c|}
\hline \multicolumn{4}{|c|}{ Vadovu veiklos vertinimo kriterijai } \\
\hline Kriterijai & $\begin{array}{l}\text { Organizacijos } \\
\text { strateginių tikslų } \\
\text { igyvendinimas }\end{array}$ & Vadovavimas & Lyderiavimas \\
\hline & $\begin{array}{l}\text { problemos sprendimo } \\
\text { būdo parinkimas, } \\
\text { sisteminis problemų ir } \\
\text { procesų ịstaigoje } \\
\text { vertinimas); } \\
\text { Kontrolès ir } \\
\text { atskaitomybès įstaigoje } \\
\text { užtikrinimas }\end{array}$ & & $\begin{array}{l}\text { tobulinimas, } \\
\text { optimizavimas ir } \\
\text { ivvertinimas, } \\
\text { naujovių diegimas, } \\
\text { pokyčių planavimas } \\
\text { ir igyvendinimas, } \\
\text { rizikos } \\
\text { analizavimas); } \\
\text { Atstovavimas } \\
\text { įstaigai }\end{array}$ \\
\hline \multicolumn{4}{|c|}{ Darbuotojų veiklos vertinimo kriterijai } \\
\hline Kriterijai & Produktyvumas & Kompetencija & Veiklos kokybè \\
\hline 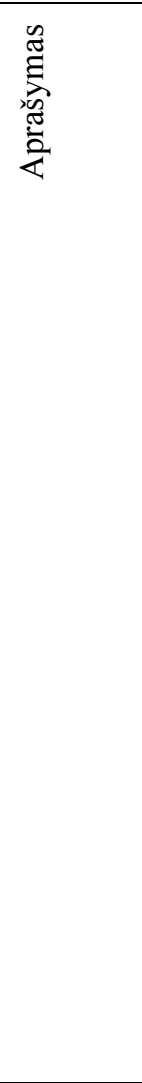 & $\begin{array}{l}\text { Pasiekti veiklos } \\
\text { rezultatai ir jų } \\
\text { atitikimas struktūrinio } \\
\text { padalinio ar įstaigos } \\
\text { nustatytiems tikslams; } \\
\text { Ivairaus apibrezžtumo, } \\
\text { kompleksiškumo ir } \\
\text { sudètingumo užduočių } \\
\text { vykdymas; } \\
\text { Informacijos valdymas } \\
\text { (jos rinkimas, } \\
\text { apdorojimas ir analizė, } \\
\text { išvadų formulavimas, } \\
\text { problemos sprendimo } \\
\text { būdo parinkimas); } \\
\text { Darbo planavimas ir } \\
\text { organizavimas, } \\
\text { efektyvus darbo laiko } \\
\text { paskirstymas; } \\
\text { Bendravimas ir } \\
\text { bendradarbiavimas } \\
\text { (darbas komandoje, } \\
\text { tarnybinè pagalba, } \\
\text { požiūris į interesantus) }\end{array}$ & $\begin{array}{l}\text { Turimų žinių ir ịgūdžių } \\
\text { panaudojimas siekiant } \\
\text { rezultatų; } \\
\text { Kvalifikacijos } \\
\text { tobulinimas; } \\
\text { Valstybės tarnautojui } \\
\text { suteiktų teisių } \\
\text { igyvendinimas ir } \\
\text { valstybės tarnautojo } \\
\text { pareigybei priskirtų } \\
\text { funkcijų atlikimas; } \\
\text { Anglu ir prancūzų (ar } \\
\text { vokiečių) kalbų geras } \\
\text { mokèjimas ir } \\
\text { gebejjimas atstovauti } \\
\text { Lietuvai Europos } \\
\text { Sajungoje (taikoma } \\
\text { valstybės tarnautojams, } \\
\text { atstovaujantiems } \\
\text { Lietuvai Europos } \\
\text { Sajungoje); } \\
\text { Asmeninė motyvacija } \\
\text { (iniciatyvumas, } \\
\text { kūrybiškumas, } \\
\text { naujovių siekimas, } \\
\text { polinkis plėsti žinias, } \\
\text { profesinis aktyvumas) }\end{array}$ & $\begin{array}{l}\text { Tinkamai ir laiku } \\
\text { atliktos užduotys; } \\
\text { Veiklos rezultatai, } \\
\text { atsižvelgiant į darbo } \\
\text { kiekybės ir kokybės } \\
\text { santykį; } \\
\text { Asmeninių tikslų } \\
\text { (veiklos rezultatų, } \\
\text { karjeros, naujovių } \\
\text { siekimo, } \\
\text { individualių } \\
\text { ugdymosi tikslų) ir } \\
\text { planų suderinimas } \\
\text { su įstaigos tikslais } \\
\text { bei planais ir jų } \\
\text { igyvendinimas; } \\
\text { Savo veiklos } \\
\text { analizė; } \\
\text { Atsakingumas už } \\
\text { darbo rezultatus }\end{array}$ \\
\hline
\end{tabular}


Europos socialinès agentūros parengtoje metodikoje (2010) darbuotojai vertinami pagal pareigybes. Siekiant aptarti praeitų metų tikslų pasiekimo lygi, išsiaiškinti, kas trukdo dirbti ir demotyvuoja, apsvarstyti darbuotojo pasiūlymus, kaip geriau pasiekti užsibrezžtus tikslus, aptarti ateinančių metų tikslus ir jų siekimo ypatumus, aptarti ugdymo poreiki, darbuotojams apklausti pritaikyta anketa, derinama su individualia apklausa. Viena vertus, R. Vanago ir A. Tuméno (2008) bei Europos socialinès agentūros taikomi vertinimo metodai leidžia išvengti subjektyvumo, kita vertus, vertinimo objektyvumas tiesiogiai priklauso nuo šių sąlygų: ar vertinamajam ir vertintojui suprantami ir aiškūs vertinimo kriterijai, nesudètingos, aiškios, atviros vertinimo procedūros, kompetentingas vertintojas.

Pažymètina, tai kad A. Šileikos et al. (2004) sukurtoje metodikoje akcentuojama būtinumas atskirti darbų (pareigybių) vertinimą, kurio pagrindu visos darbo vietos (pareigybès) suskirstomos i atitinkamą tarifinių kategorijų skaičių pagal darbo sudetingumą, nuo darbuotojo, užimančio konkrečią darbo vietą (pareigybę), veiklos efektyvumo bei profesionalumo ir kitų savybių vertinimo. Autoriai akcentuoja, kad tokia vertinimo sistema leidžia ìvairaus sudètingumo (plačiaja prasme) darbus sugrupuoti ir suklasifikuoti, palyginant juos tarpusavyje, bei tuo pagrindu nustatyti pagrindinio (bazinio) darbo užmokesčio skales. Visgi, kuriant žinių vertinimo veiksnių sistemą būtina išskirti pagrindinius veiksnius, kurie atspindètų kiekvieno darbuotojo žinias nepriklausomai nuo pareigybès.

Veiksnių sistemos sudarymas yra sudètingas procesas, nes tyrèjai, priklausomai nuo tyrimo objekto ar nagrinejjamo reiškinio, išrenka tik tam objektui tinkamus ir svarbius veiksnius, todèl itraukiamų veiksnių skaičius ir sudètis priklauso tiek nuo tyrejjų, tiek nuo vertintojų kvalifikacijos. Kitaip tariant, ekspertai ị sistemą įtrauks tik, jų nuomone, tikrai svarbius veiksnius. Kita vertus, netgi taip sudarytoje sistemoje atsidurs labai nevienareikšmiški savo poveikiu nagrinèjamam reiškiniui veiksniai (Podvezko 2008). İ sistemą gali būti įtrauktas ribotas veiksnių skaičius: kai jų per daug, neįmanoma tiksliai įvertinti kiekvieno veiksnio poveikio galutiniam rezultatui. Atlikus žinių veiksnių analizę gaunama žinių vertinimo veiksnių aibè apjungianti 27 veiksnius (D priedas).

Žinių vertinimo veiksnių skaičius yra didesnis nei 20 (i $>20)$, todèl būtina išgryninti svarbiausius veiksnius tam taikant grupavimą, i poaibius suskirstant juos pagal svarbą (3.6 lentelè). Pradinių žinių veiksnių aibę $V=\left\{V_{l}, V_{2}, \ldots V i\right\}$ tikslinga išreikšti trimis poaibiais $V_{A}, V_{B}$ ir $V_{C}$, priklausančiais nuo jų įtakos pagrindiniam nagrinejjamam tikslui - žinių sinergijos vertinimui: $V_{A}$ - poaibis veiksnių, turinčių didžiausią įtaką žinių sinergijai; $V_{B}$ - poaibis veiksnių, turinčių vidutinę įtaką žinių sinergijai; $V_{C}$ - poaibis veiksnių, mažiausiai veikiančių arba visai neturinčių įtakos žinių sinergijai. Intervalų riboms nustatyti skaičiuotas visų 
veiksnių vidurkis, kurio rezultatai tokie: $V_{A}$ poaibiui priskirtas dažnumo intervalas (19-27), $V_{B}-(10-18)$, o $V_{C}-(1-9)$. Žinodami $V_{C}$ poaibio veiksnius, galime juos pašalinti iš aibès $V$ ir taip išgryninti svarbiausius.

3.6 lentelè. Žinių vertinimo veiksnių poaibiai (sudaryta autorès)

Table 3.6. Knowledge evaluation factor subsets (compiled by the author)

\begin{tabular}{|c|c|c|c|c|}
\hline Veiksnys & 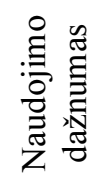 & 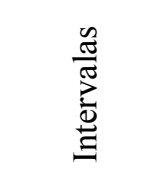 & $\begin{array}{l}\frac{n}{0} \\
\frac{0}{0} \\
0 \\
0\end{array}$ & 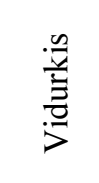 \\
\hline Išsilavinimas & 26 & $(19-27)$ & $V_{A}$ & \multirow[t]{2}{*}{25,5} \\
\hline Technologijų panaudojimas & 25 & $(19-27)$ & $V_{A}$ & \\
\hline Profesinè patirtis & 17 & $(10-18)$ & $V_{B}$ & \multirow[t]{4}{*}{12,75} \\
\hline Motyvacija & 14 & $(10-18)$ & $V_{B}$ & \\
\hline $\begin{array}{l}\text { Darbuotojo itaka organizacijos tikslu } \\
\text { realizavimui }\end{array}$ & 10 & $(10-18)$ & $V_{B}$ & \\
\hline Pareigų ir vadybos lygiai & 10 & $(10-18)$ & $V_{B}$ & \\
\hline Darbo sudètingumas & 9 & $(1-9)$ & $V_{C}$ & \multirow[t]{19}{*}{3,19} \\
\hline Darbo kultūra & 9 & $(1-9)$ & $V_{C}$ & \\
\hline Darbuotojo darbo užmokestis & 8 & $(1-9)$ & $V_{C}$ & \\
\hline Atsakomybė & 7 & $(1-9)$ & $V_{C}$ & \\
\hline Savarankiškumas darbe & 7 & $(1-9)$ & $V_{C}$ & \\
\hline Sprendimų mastas ir veikimo laisvė & 3 & $(1-9)$ & $V_{C}$ & \\
\hline Atsakomybè už informacijos saugojimą & 2 & $(1-9)$ & $V_{C}$ & \\
\hline $\begin{array}{l}\text { Asmeninè atsakomybė už atliekamą darbą ir jo } \\
\text { kokybę }\end{array}$ & 2 & $(1-9)$ & $V_{C}$ & \\
\hline Dalyvavimas priimant vadybos sprendimus & 2 & $(1-9)$ & $V_{C}$ & \\
\hline Darbo sąlygų problemos & 2 & $(1-9)$ & $V_{C}$ & \\
\hline $\begin{array}{l}\text { Darbo užduočiu vykdymas laiku, darbo } \\
\text { planavimas }\end{array}$ & 2 & $(1-9)$ & $V_{C}$ & \\
\hline Vadovavimas darbo kolektyvui & 2 & $(1-9)$ & $V_{C}$ & \\
\hline Kvalifikacijos tobulinimas & 2 & $(1-9)$ & $V_{C}$ & \\
\hline Asmeniniai kriterijai & 2 & $(1-9)$ & $V_{C}$ & \\
\hline Socialinė reikšmė & 2 & $(1-9)$ & $V_{C}$ & \\
\hline Darbo patirtis & 1 & $(1-9)$ & $V_{C}$ & \\
\hline Kontaktų intensyvumas įmonèje & 1 & $(1-9)$ & $V_{C}$ & \\
\hline Darbo savarankiškumas ir kūrybiškumas & 1 & $(1-9)$ & $V_{C}$ & \\
\hline Kontaktų intensyvumas už įmonės ribų & 1 & $(1-9)$ & $V_{C}$ & \\
\hline
\end{tabular}


3.6 lentelès pabaiga

\begin{tabular}{|c|c|c|c|c|}
\hline Veiksnys & 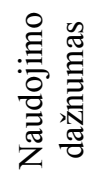 & 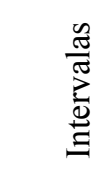 & 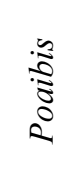 & ב \\
\hline Darbo sąlygos & 1 & $(1-9)$ & $V_{C}$ & \\
\hline Bendravimas ir bendradarbiavimas & 1 & $(1-9)$ & $V_{C}$ & \\
\hline
\end{tabular}

Kuo daugiau veiksnių itraukiama i sistemą, tuo sunkiau nustatyti jų reikšmingumą, kita vertus, išsamiau atspindimas nagrinëjamas reiškinys (Joro, Viitala 1999, Ginevičius, Podvezko 2007) Kai veiksnių skaičius yra palyginti nemažas, tiesioginis veiksnių vertinimas ir nuoseklus visų veiksnių lyginimas yra sudètingas (Podvezko 2008). Kai veiksnių yra daugiau kaip 12, ekspertas negali teisingai nustatyti įtakos santykių tarp visų porų veiksnių (Ginevičius 2006), todèl sudarant veiksnių vertinimo sistemą rekomenduojama įtraukti ne daugiau nei dvylika veiksnių. Veiksniai, reikšmingi žinių sinergijos vertinimui, patenka ị žinių vertinimo veiksnių aibę iš $V_{A}$ ir $V_{B}$ poaibių. Poaibyje $V_{C}$ yra veiksnių, kurių pasikartojimo dažnis yra nuo 9 iki 7 tai - darbo sudètingumas, darbo kultūra, darbuotojo darbo užmokestis, atsakomybè. Šių veiksnių dažniai nuo vidurkio nutolę atitinkamai 5,81 iki 3,81 ir standartinis nuokrypis yra atitinkamai 2,62 ir 0,62 . Pažymètina, kad veiksnių su pasikartojimo dažniais nuo 9 iki 7 iš poaibio $V_{C}$ nuo poaibio $V_{B}$ vidurkio nutolę atitinkamai 3,75 iki 5,75 , todèl juos būtina įtraukti į žinių vertinimo veiksnių aibę. Veiksniai - savarankiškumas darbe bei sprendimų mastas ir veikimo laisvè - yra persidengiantys, todèl juos būtina sujungti į vieną veiksnị. Sujungto veiksnio - savarankiškumas darbe - naudojimo dažnis yra 10 . Toks dažnio dydis rodo, kad šis veiksnys patenka i antraji poaibị $V_{B}$.

Kvalifikacijos tobulinimo veiksnys taip pat daro didelę ịtaką darbuotojo žinioms, konkurencingumo didinimui ir jo darbo efektyvumui. Kvalifikacijos sąvoka pastaraisiais dešimtmečiais buvo labiau siejama su profesinio rengimo sistemos kaitos ir raidos etapais. Kvalifikacija - žmogaus tinkamumo tam tikrai profesinei veiklai atlikti formalaus pripažinimo laipsnis, kurị lemia turimos žinios, gebejjimai ir vertybinès nuostatos (Lobanova, Chlivickas 2009). Darbuotojas organizacijoje bus konkurencingas tik tada, kai nuolatos kels savo kvalifikaciją, t. y. gerins savo asmenines žinias, tobulins įgūdžius. Kvalifikacijos tobulinimą kaip būtiną veiksnį, darantị didelę itaką turimoms asmens žinioms bei žinių turinio vertinimui, būtina įtraukti į žinių veiksnių vertinimo sistemą.

Atlikus metaduomenų analizę, išgryninus svarbiausius žinių vertinimo veiksnius, tikslinga veiksnius, turinčius įtakos darbuotojo žinioms, suskirstyti ị du 
blokus - išreikštines ir neišreikštines žinias, pakoreguojant kai kurių veiksnių pavadinimus (3.7 lentelè).

3.7 lentelè. Darbuotojo žinioms darantys ịtaką veiksniai (sudaryta autorès)

Table 3.7. Factors influencing employee knowledge (compiled by the author)

\begin{tabular}{|c|c|c|c|c|c|c|c|c|c|c|c|}
\hline \multicolumn{6}{|c|}{ Išreikštinės žinios (koeficientas $-\alpha$ ) } & \multicolumn{6}{|c|}{ Neišreikštinès žinios (koeficientas $-\beta$ ) } \\
\hline 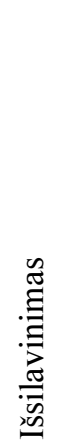 & 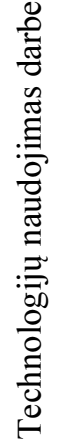 & $\begin{array}{l}\mathscr{n} \\
0 \\
0 \\
0 \\
0 \\
0 \\
0 \\
0 \\
0 \\
0 \\
0\end{array}$ & 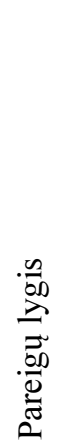 & 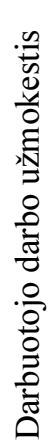 & 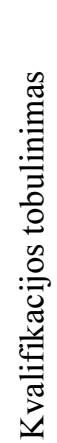 & 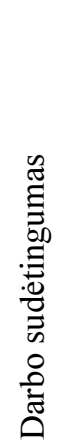 & 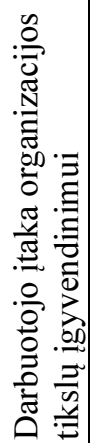 & 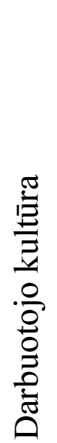 & 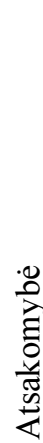 & 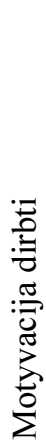 & 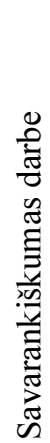 \\
\hline
\end{tabular}

Išreikštines žinias siūloma skaičiuoti taip:

$$
V I=\tilde{i} I+\tilde{t} T+\widetilde{p} P+\tilde{l} L+\widetilde{u} U+\widetilde{f} F,
$$

čia $V I$ - išreikštinių žinių ịvertis, $\tilde{\imath}$ - išsilavinimo veiksnio koeficientas, Iišsilavinimo veiksnys, $\tilde{t}$ - technologiju naudojimo darbe veiksnio koeficientas, $T$ - technologiju naudojimo darbe veiksnys, $\tilde{p}$ - profesinès patirties veiksnio koeficientas, $P$ - profesinès patirties veiksnys, $\tilde{l}$ - pareigu lygio veiksnio koeficientas, $L$ - pareigų lygio veiksnys, $\tilde{u}$ - darbuotojo darbo užmokesčio veiksnio koeficientas, $U-$ darbuotojo darbo užmokesčio veiksnys, $\tilde{f}-$ kvalifikacijos tobulinimo veiksnio koeficientas, $F$ - kvalifikacijos tobulinimo veiksnys.

Neišreikštines žinias siūloma skaičiuoti taip:

$$
V N=\tilde{g} G+\tilde{o} O+\tilde{k} K+\tilde{a} A+\tilde{m} M+\tilde{v} V,
$$

čia $V N$ - neišreikštinių žinių įvertis, $\tilde{g}$ - darbo sudètingumo veiksnio koeficientas, $G$ - darbo sudettingumo veiksnys, $\tilde{o}$ - darbuotojo įtaka organizacijos tikslų igyvendinimui veiksnio koeficientas, $O$ - darbuotojo itaka organizacijos tikslų igyvendinimui veiksnys, $\tilde{k}$ - darbo kultūros veiksnio koeficientas, $K$ - darbo kultūros veiksnys, $\tilde{a}$ - atsakomybès veiksnio koeficientas, $A$ - atsakomybès veiksnys, $\widetilde{m}$ - motyvacijos dirbti veiksnio koeficientas, $M$ - motyvacijos dirbti 
veiksnys, $\tilde{v}$ - savarankiškumo darbe koeficientas, $V$ - savarankiškumo darbe veiksnys.

Darbuotojo žinių vertinimo formulè, detalizavus išreikštinių ir neišreikštinių žinių veiksnius, igyja tokią išraišką:

$$
\begin{gathered}
\hat{\mathrm{Z}}=\alpha(\tilde{\imath} I+\tilde{t} T+\tilde{p} P+\tilde{l} L+\tilde{u} U+\tilde{f} F)+ \\
+\beta(\tilde{g} G+\tilde{o} O+\tilde{k} K+\tilde{a} A+\tilde{m} M+\tilde{v} V) .
\end{gathered}
$$

Apjungiant organizacijos darbuotojų žinių sinergijos komponentų vertinimo formules i bendrą organizacijos darbuotojų žinių sinergijos vertinimą sudarytas vertinimo matematinių išraiškų konstruktas (3.2 pav.).

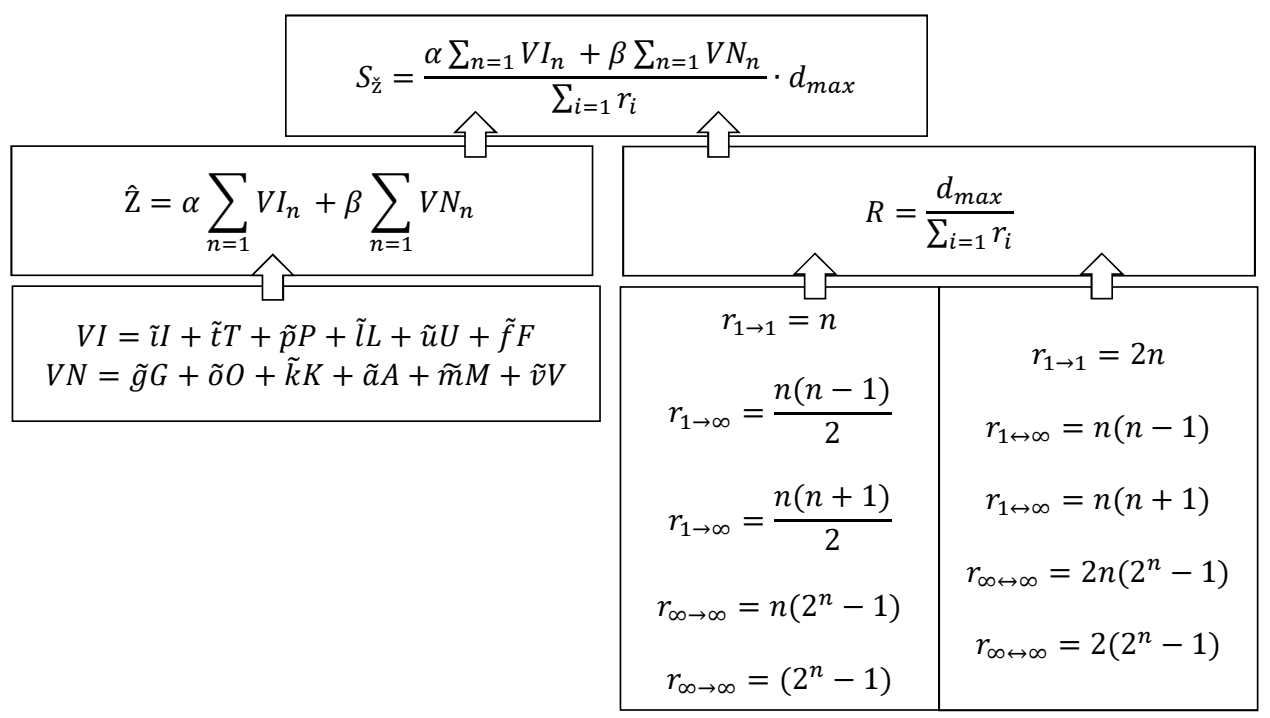

3.2 pav. Žinių sinergijos vertinimo matematinis konstruktas (sudarytas autorès)

Fig. 3.2. Mathematical model of knowledge synergy evaluation (compiled by the author)

Žinių sinergijos komponentų skaičiavimai leidžia visapusiškai įvertinti ne tik darbuotojo žinias ir ryšius tarp darbuotojų, bet atskleidžia organizacijos darbuotojų žinių sinergijos turinị. Atsižvelgiant $\mathfrak{i}$ žinių sinergijos vertinimo rezultatus galima koreguoti darbuotojų ryšius, žinių dalijimosi procesus, keisti arba integruoti naujas žinių dalijimosi bei bendradarbiavimo skatinimo priemones. 


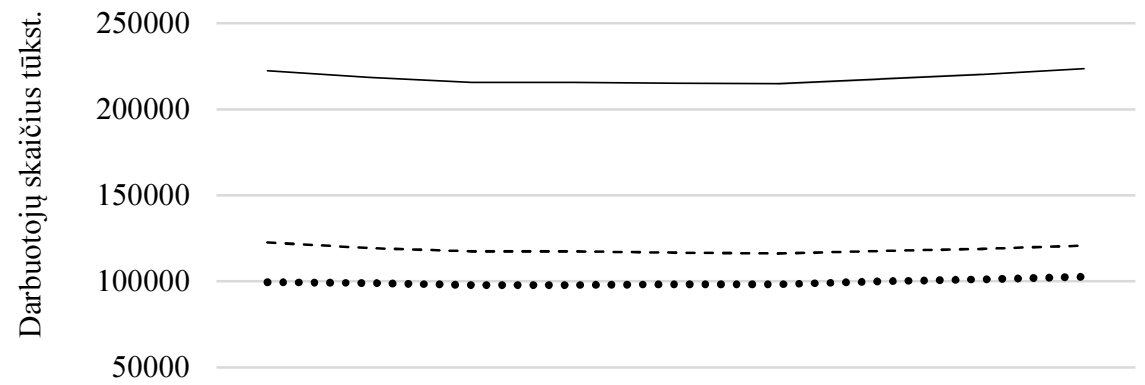

\begin{tabular}{|c|c|c|c|c|c|c|c|c|c|}
\hline & 2008 & 2009 & 2010 & 2011 & 2012 & 2013 & 2014 & 2015 & 2016 \\
\hline & 22242 & 21850 & 21564 & 215641 & 215288 & 21498 & 21775 & 22023 & 223680 \\
\hline -.--- Vyrai & 122744 & 110458 & 117646 & 117646 & 116842 & $11631 \mathrm{C}$ & 11771 & 11900 & 120864 \\
\hline •..... Moterys & 99682 & 99048 & 97995 & 97995 & 98446 & 98446 & 100045 & 101229 & 102816 \\
\hline
\end{tabular}

3.3 pav. Užimtumas technologijomis ir žiniomis imliuose sektoriuose pagal lytị (Sudaryta remiantis Eurostat 2017)

Fig. 3.3. Employment in technology- and knowledge-intensive sectors by sex (compiled according to Eurostat 2017)

Daugelis tyrimų patvirtina, kad sudètinga ịvertinti darbuotojo žinias, o žinių sinergijos atveju tai padaryti yra dar sudètingiau. Asmens žinių ir žinių sinergijos vertinimo problema šiandien yra labai aktuali, tai taip pat patvirtinta naujausioje Eurostato analizeje (Eurostatas 2017a, Eurostatas 2017b). Akivaizdu, kad užimtumas žinių sektoriuose didèja nuo 2013 m., o moterų užimtumo atveju jis šiek tiek padidejo net ir nuo $2010 \mathrm{~m}$. (3.3 pav.). Naujos tendencijos bei technologine pažanga ateityje siejama su didejančiais darbuotojų žinių reikalavimais.

\section{2. Žinių sinergijos komponento - ryšiai tarp darbuotojų - vertinimo siūlymai}

Atsižvelgiant ị ryšių tipus ir efektyvių ryšių skaičiavimo metodus skirtingo tipo ryšiams skaičiuoti taikytina atitinkama formulè (3.8 lentelè). 
3.8 lentelè. Ryšių tarp darbuotojų formulès (sudaryta autorès)

Table 3.8. Formulas of relations among employees (compiled by the author)

\begin{tabular}{|c|c|c|c|}
\hline $\begin{array}{l}\text { Ryšio } \\
\text { tipas }\end{array}$ & Tipų apibūdinimas & Vienpusis kelio ryšys & Abipusis kelio ryšys \\
\hline \multirow[t]{2}{*}{$\begin{array}{l}\text { Vienas } \\
\text { su vienu }\end{array}$} & $\begin{array}{l}\text { Ryšiai tarp vadovo ir } \\
\text { pavaldžių darbuotojų }\end{array}$ & $r_{1 \rightarrow 1}=n$ & $r_{1 \leftrightarrow 1}=2 n$ \\
\hline & $\begin{array}{l}\text { Ryšiai tarp grupès } \\
\text { darbuotojų (cecho ar } \\
\text { konvejerinès } \\
\text { gamybos darbuotojų } \\
\text { grupèje) }\end{array}$ & $r_{1 \rightarrow 1}=\frac{n(n-1)}{2}$ & $r_{1 \leftrightarrow 1}=n(n-1)$ \\
\hline \multirow[t]{2}{*}{$\begin{array}{l}\text { Vienas } \\
\text { su daug }\end{array}$} & $\begin{array}{l}\text { Ryšiai tarp vadovo ir } \\
\text { grupės darbuotojų }\end{array}$ & $r_{1 \rightarrow \infty}=\frac{n(n+1)}{2}$ & $r_{1 \leftrightarrow \infty}=n(n+1)$ \\
\hline & $\begin{array}{l}\text { Ryšiai tarp vadovo ir } \\
\text { tarp grupès } \\
\text { darbuotojų }\end{array}$ & $r_{\infty \rightarrow \infty}=n\left(2^{n}-1\right)$ & $r_{\infty \leftrightarrow \infty}=2 n\left(2^{n}-1\right)$ \\
\hline $\begin{array}{l}\text { Daug su } \\
\text { daug }\end{array}$ & $\begin{array}{l}\text { Ryšiai grupėje tarp } \\
\text { grupės darbuotojų }\end{array}$ & $r_{\infty \rightarrow \infty}=\left(2^{n}-1\right)$ & $r_{\infty \leftrightarrow \infty}=2\left(2^{n}-1\right)$ \\
\hline
\end{tabular}

Siekiant nustatyti galutini ryšiu įvertị rekomenduotina sudaryti matricą, pagal aukščiau pateiktą 3.8 lentelę. Śioje matricoje turètų atsispindèti esami ryšių tipai organizacijoje, nes esant vieno tipo ryšiams ir penkioms formulèms gaunama net 31 pasirinkimo variantų kombinacija, o jei yra abiejų ryšių tipai, kombinacijų skaičius didejja iki 933. Pasirengus darbuotojų ryšių matricą, bus galima nesudètingai apskaičiuoti galutini ryšių tarp darbuotojų įvertị. Galutiniam ryšių apskaičiavimui siūloma (2.6) formulè.

\section{3. Žinių sinergijos komponento - darbuotojo žinios - vertinimo metodụ pasirinkimo tikslingumas}

M. Alkin (2004) teigia, kad vertinimą svarbu suvokti kaip tam tikro objekto vertès nustatymo procesą. Siekiant organizacijos ar jos tam tikrų veiklų vertinimo sklandumo šis procesas struktūruojamas. Pavyzdžiui, C. V. Patton et al. (2012) siūlo vertinimą vykdyti laikantis tam tikro nuoseklumo ir pateikia šešių vertinimo etapų schemą (3.4 pav.). 


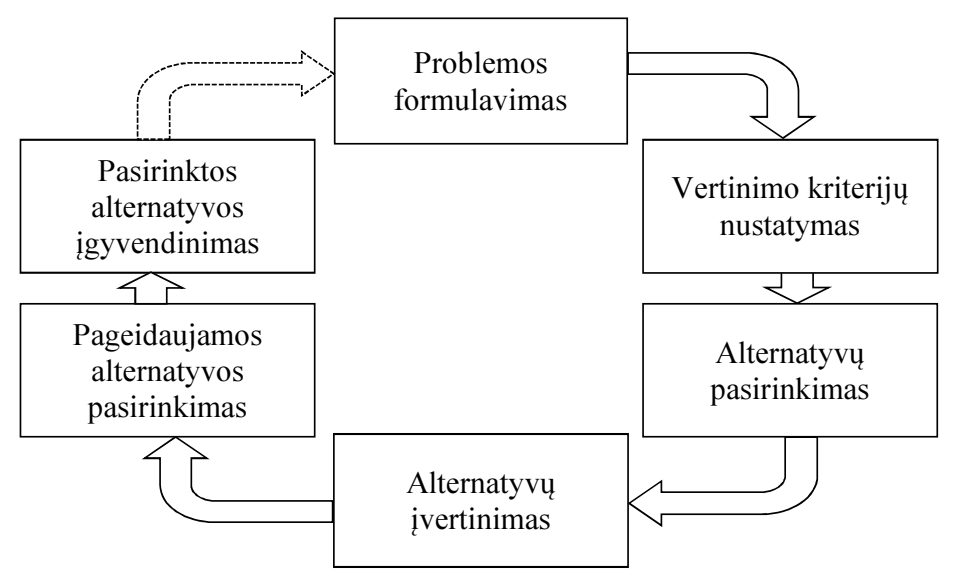

3.4 pav. Klasikinio vertinimo schema (Patton et al. 2012)

Fig. 3.4. Classical evaluation scheme (Patton et al. 2012)

C. V. Patton et al. (2012) pateikta klasikinio vertinimo schema tinkama ivairiems objektams vertinti. Vis dèlto, A. Baležentis ir T. Baležentis (2011) išskiria savitus sudètingiems uždaviniams taikomų daugiakriterinio vertinimo metodų žingsnius: tikslų ir juos atitinkančių rodiklių sistemos sudarymas, jų reikšmingumo nustatymas; atsakų matricos suformavimas ir normalizavimas pritaikant daugiakriterinius sprendimų prièmimo metodus; gautų rezultatų interpretavimas ir sprendimų prièmimas. Iprastai, daugelis tyrëjų, spręsdami daugiakriterinius vertinimo uždavinius, vertinimus atlieka taikant algoritmą (3.5 pav.), kuris pradedamas nuo tikslų ir juos atitinkančių rodiklių sistemos sudarymo ir baigiamas sprendimų priemimo procesu.

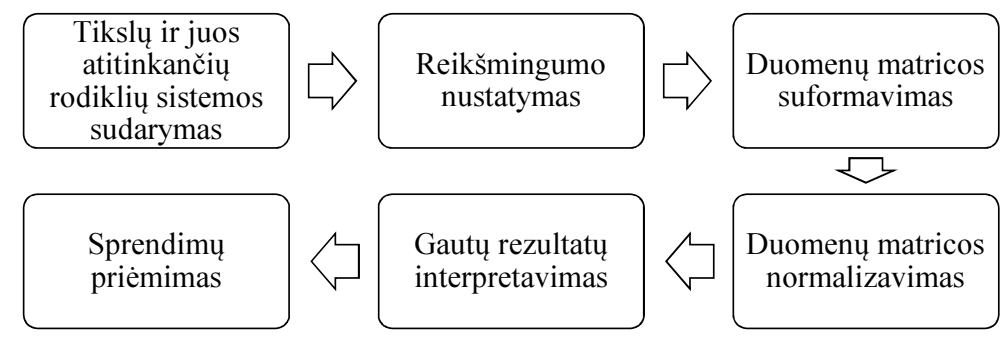

3.5 pav. Daugiakriterinio vertinimo algoritmas (sudaryta autorès pagal Podvezko 2008, Baležentis, Baležentis 2011)

Fig. 3.5. Algorythm of ulticriteria evaluation (compiled by the author based on Podvezko 2008, Baležentis, Baležentis 2011) 
Daugiakriterinio vertinimo metodų taikymą schematizavo A. Guitouni, J. M. Martel (1998): iš turimų pradinių duomenų modeliuojama situacija, duomenys apdorojami ir gaunamas vertinimo rezultatas (3.6 pav.).

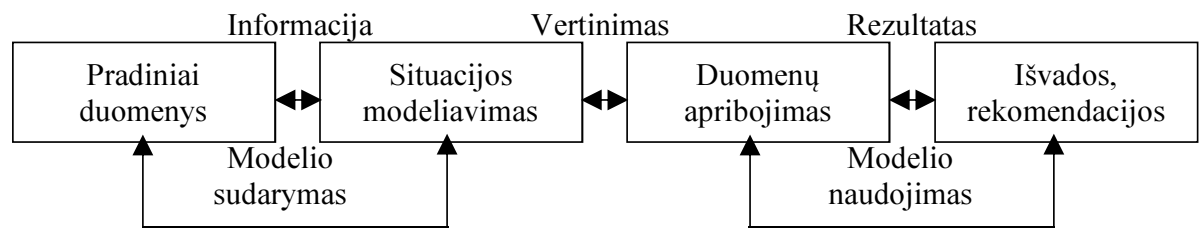

3.6 pav. Daugiakriterinio vertinimo schema (Guitouni, Martel 1998)

Fig. 3.6. Multicriteria evaluation scheme (Guitouni, Martel 1998)

D. Andriušaitienè et al. (2008) daugiakriterinị vertinimą siūlo pradèti nuo tyrimo objekto identifikavimo ir baigti sprendimu prièmimo dèl nagrinejjamo reiškinio būsenos pagerinimo (3.7 pav.). N. Slavinskaitė (2012) siūlo daugiakriterinius vertinimus vykdyti panašia seka, tik pirmaji ir antraji etapus sujungia i vieną. A. Z. Sarraf et al. (2012) daugiakriteriniam vertinimui naudoja keturis žingsnius, tai yra: objekto ir problemų formulavimas, alternatyvų ir ivvertinimo kriterijų nustatymas, modelio taikymas, tinkamiausio sprendimo parinkimas.



3.7 pav. Daugiakriterinio vertinimo etapai (sudaryta autorès pagal Andriušaitienę 2008) Fig. 3.7. Multicriteria evaluation stages (compiled by the author based on Andriušaitienè 2008) 
V. Podvezko (2008) teigia, kad nepriklausomai nuo sprendžiamo uždavinio, taikant daugiakriterinius metodus, tyrinètojas nagrinèja tokius pagrindinius kompleksinio uždavinio etapus (nebūtinai visus):

- sudètingų dydžių dalinių rodiklių sistemos formavimas;

- taikomų rodiklių statistinių duomenų arba ekspertų vertinimų paruošimas;

- duomenų transformavimas ir normalizavimas;

- rodiklių reikšmingumo nustatymas - jų svorių skaičiavimas;

- skirtingų daugiakriterinių metodų ypatingumo, metodų apribojimų analizè, konkrečių, tinkamų vertinimui daugiakriterinių metodų pasirinkimas, atskirų rezultatų suderinamumo analizé;

- sudètingu dydžiu hierarchijos formavimas ir hierarchijos struktūros kiekybinis įvertinimas;

- pagrindinio hierarchijos lygmens rodiklių kompleksinis vertinimas;

- duomenu neapibrèžtumo ịtakos daugiakriteriniuose metoduose vertinimas, modelių parametrų keitimo intervalų nustatymas.

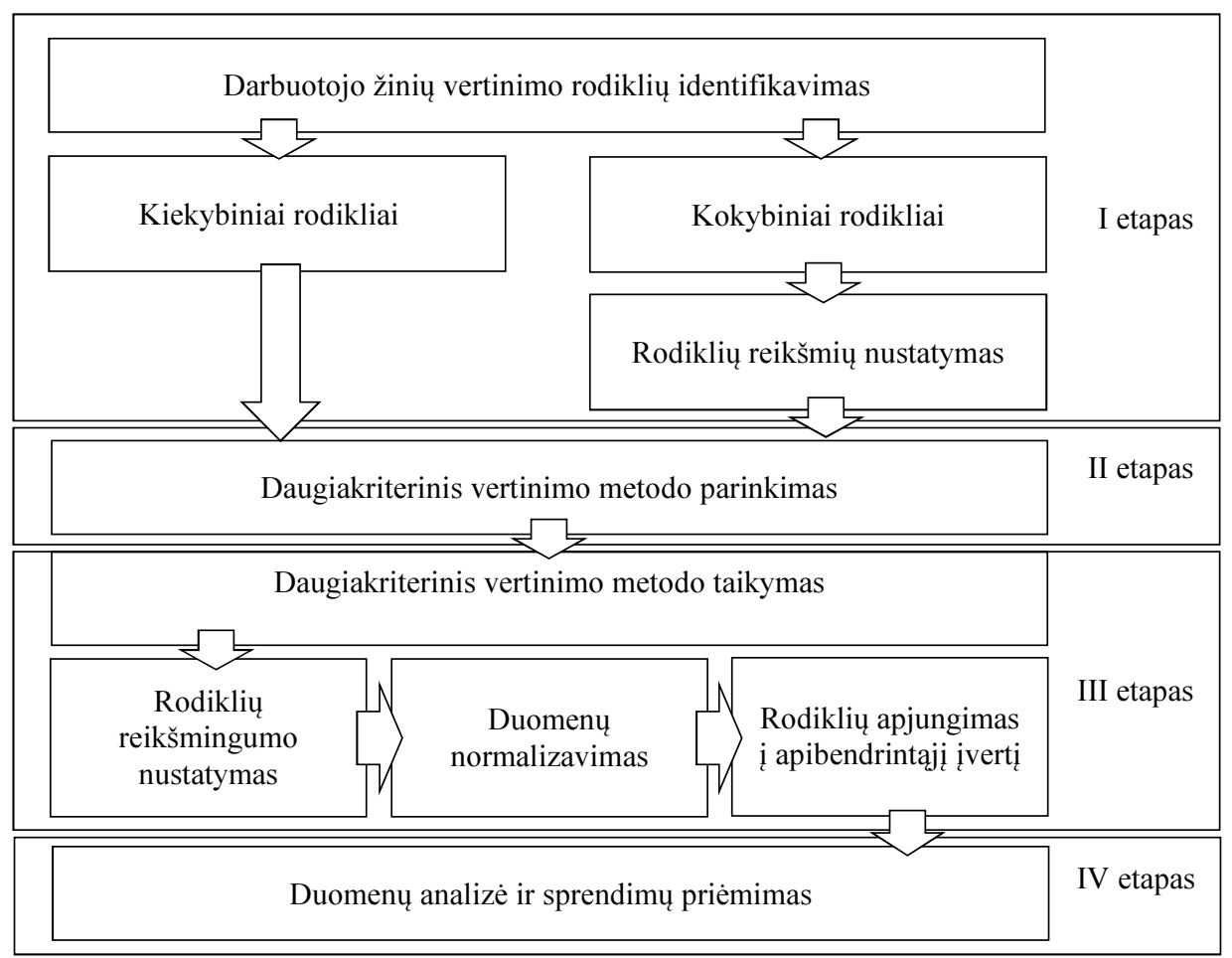

3.8 pav. Darbuotojo žinių vertinimo algoritmas (sudaryta autorès)

Fig. 3.8. Employee knowledge evaluation algorythm (compiled by the author) 
Sudètingų objektų kompleksinį vertinimą sudaro tam tikri vertinimo etapai, iprastai pradedama nuo tyrimo problemos formulavimo, dalinių rodiklių sistemos formavimo, komponentų hierarchinio struktūrizavimo ir baigiama tiriamo reiškinio apibendrinamojo dydžio nustatymu ir taikomų modelių stabilumo tikrinimu. Apibendrinant daugelio tyrèjų išskirtus daugiakriterinio vertinimo etapus, sudaryta darbuotojo žinių vertinimo technologija taikant tiesinį algoritmą (3.8 pav.). Toliau skyriuje detaliau nagrinejjami 1-2 etapai.

Darbuotojo žinių vertinimo rodiklių sistema sudaryta iš dviejų posistemių: atsižvelgiant ị žinių tipus darbuotojo žinios sugrupuotos ị du blokus - išreikštines ir neišreikštines žinias (Skačkauskienè et al. 2017), o pastarieji sudaryti iš atitinkamų veiksnių. Išreikštinių žinių bloko veiksniai turi ir kiekybines, ir kokybines išraiškas, o jų detalizuotas turinys pateiktas 3.9 lentelejje.

3.9 lentelè. Išreikštinių žinių veiksnių bloko kiekybiniai ir kokybiniai veiksniai (sudaryta autorès)

Table 3.9. Quantitative and qualitative factors of explicit knowledge factor block (compiled by the author)

\begin{tabular}{|c|c|c|c|}
\hline \multicolumn{2}{|r|}{ Veiksniai } & \multirow[t]{2}{*}{ Veiksnio dedamosios } & \multirow{2}{*}{$\begin{array}{l}\text { Matavi- } \\
\text { mo } \\
\text { vienetas }\end{array}$} \\
\hline Tipas & Pavadinimas & & \\
\hline \multirow{3}{*}{$\begin{array}{l}: \frac{n}{\Xi} \\
\frac{2}{2} \\
\frac{2}{2}\end{array}$} & $\begin{array}{l}\text { Kvalifikacijos } \\
\text { tobulinimas }\end{array}$ & $\begin{array}{l}\text { Kursu skaičius: } \\
\text { Per metus. } \\
\text { Kompiuterinio raštingumo pažymėjimas (ECDL) } \\
\text { Kalbų mokejjimo sertifikatai }\end{array}$ & $\begin{array}{l}\text { val. } \\
\text { vnt. } \\
\text { vnt. }\end{array}$ \\
\hline & Profesine patirtis & $\begin{array}{l}\text { Darbo stažas: } \\
\text { 1) visas darbo stažas } \\
\text { 2) stažas pagal profesiją }\end{array}$ & $\begin{array}{l}\text { metai } \\
\text { metai }\end{array}$ \\
\hline & $\begin{array}{l}\text { Darbuotojo darbo } \\
\text { užmokestis }\end{array}$ & $\begin{array}{l}\text { Etato dydis } \\
\text { Valandinis darbo užmokestis (neatskaičiavus } \\
\text { mokesčių) } \\
\text { arba } \\
\text { mėnesinis darbo užmokestis (neatskaičiavus } \\
\text { mokesčių) }\end{array}$ & $\begin{array}{l}\text { vnt. } \\
\text { valiuta } \\
\text { valiuta }\end{array}$ \\
\hline \multirow{7}{*}{ 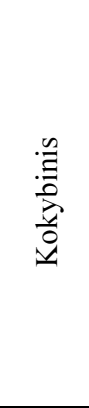 } & \multirow[t]{7}{*}{ Išsilavinimas } & $\begin{array}{l}\text { Išsilavinimo pakopa: } \\
\text { pradinis }\end{array}$ & 1 balas \\
\hline & & progimnazinis (pagrindinis) & 2 balai \\
\hline & & gimnazinis (vidurinis) & 3 balai \\
\hline & & profesinis išsilavinimas arba specialusis vidurinis & 4 balai \\
\hline & & $\begin{array}{l}\text { aukštesnysis išsilavinimas arba aukštasis } \\
\text { neuniversitetinis išsilavinimas (profesinis } \\
\text { bakalauras) }\end{array}$ & 5 balai \\
\hline & & $\begin{array}{l}\text { aukštasis universitetinis išsilavinimas } \\
\text { (bakalauras) }\end{array}$ & 6 balai \\
\hline & & aukštasis universitetinis išsilavinimas (magistras) & 7 balai \\
\hline
\end{tabular}


3.9 lentelès pabaiga

\begin{tabular}{|c|c|c|c|}
\hline \multicolumn{2}{|r|}{ Veiksniai } & \multirow[t]{2}{*}{ Veiksnio dedamosios } & \multirow{2}{*}{$\begin{array}{l}\text { Matavi- } \\
\text { mo } \\
\text { vienetas }\end{array}$} \\
\hline Tipas & Pavadinimas & & \\
\hline & & mokslų daktaras & 8 balai \\
\hline & \multirow{4}{*}{$\begin{array}{l}\text { Technologijų } \\
\text { naudojimas darbe }\end{array}$} & Nenaudojama nei technologijos, nei kompiuteris & 1 balas \\
\hline & & Darbe naudojamas kompiuteris & 5 balai \\
\hline & & $\begin{array}{l}\text { Darbas prie staklių, aparatų reikalaujančių } \\
\text { technologinių žinių }\end{array}$ & 7 balai \\
\hline & & $\begin{array}{l}\text { Darbe naudojamas kompiuteris ir kuriamos } \\
\text { technologijos }\end{array}$ & 10 balų \\
\hline & \multirow[t]{4}{*}{ Pareigų lygis } & $\begin{array}{l}\text { I lygis: pagalbinis darbuotojas, sargas, valytojas, } \\
\text { apsaugininkas }\end{array}$ & 3 balai \\
\hline & & $\begin{array}{l}\text { II lygis: administracijos darbuotojas, darbuotojas, } \\
\text { vadybininkas, valstybės tarnautojas }\end{array}$ & 5 balai \\
\hline & & III lygis: cecho viršininkas, brigadininkas & 8 balai \\
\hline & & IV lygis: vadovas, pavaduotojas, skyriaus vedejas & 10 balų \\
\hline
\end{tabular}

Neišreikštinių žinių bloko veiksniai yra kokybinio pobūdžio. Šio bloko veiksniams ìvertinti pasiūlytos dedamosios, apibūdinančios veiksnių turinị (3.10 lentelè). Kokybinių darbuotojo žinių veiksnių dedamosioms vertinti priskiriami balai. Kadangi veiksnius apibūdinančių dedamujų skaičius skiriasi, todèl skiriasi ir vertinimo balai. Pavyzdžiui, jeigu darbuotojas nesprendžia jokių strateginių tikslų ir neturi įtakos organizacijos tikslų igyvendinimui skiriama nulis balų, bet jeigu darbuotojas dalyvauja ịvairiose darbo grupèse, atlieka ịvairius sudètingus darbus, ieško partnerių, t. y. stipriai daro įtaką organizacijos tikslų igyvendinimui - skiriama 10 balų.

3.10 lentelè. Neišreikštinių žinių veiksniai (sudaryta autorès)

Table 3.10. Tacit knowledge factors (compiled by the author)

\begin{tabular}{|c|c|c|c|}
\hline \multicolumn{2}{|r|}{ Veiksniai } & \multirow[t]{2}{*}{ Veiksnio dedamosios } & \multirow[t]{2}{*}{ Balai } \\
\hline Tipas & Pavadinimas & & \\
\hline \multirow{9}{*}{ 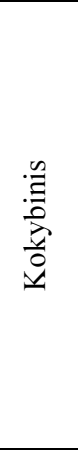 } & \multirow{4}{*}{$\begin{array}{l}\text { Darbo } \\
\text { sudètingumas }\end{array}$} & Nesudètingas fizinis darbas & 3 \\
\hline & & $\begin{array}{l}\text { Fizinis darbas, epizodiškai sukeliantị nervinę } \\
\text { jtampą }\end{array}$ & 5 \\
\hline & & Darbas, susijęs su nuolatiniu protiniu aktyvumu & 8 \\
\hline & & $\begin{array}{l}\text { Didelès protinės ir nervinès įtampos darbas, susijęs } \\
\text { su nuolatiniu rūpesčiu dèl visos organizacijos } \\
\text { veiklos }\end{array}$ & 10 \\
\hline & \multirow{5}{*}{$\begin{array}{l}\text { Darbuotojo ịtaka } \\
\text { organizacijos } \\
\text { tikslų } \\
\text { igyvendinimui }\end{array}$} & Nèra įtakos & 0 \\
\hline & & Silpna ittaka & 3 \\
\hline & & Vidutinè ittaka & 5 \\
\hline & & Stipri itaka & 8 \\
\hline & & Labai stipri itaka & 10 \\
\hline
\end{tabular}


3.10 lentelès pabaiga

\begin{tabular}{|c|c|c|c|}
\hline \multicolumn{2}{|r|}{ Veiksniai } & \multirow[t]{2}{*}{ Veiksnio dedamosios } & \multirow[t]{2}{*}{ Balai } \\
\hline Tipas & Pavadinimas & & \\
\hline & \multirow[t]{5}{*}{ Darbo kultūra } & Nepripažista kitų nuomonès, dažnai konfliktuoja & 1 \\
\hline & & Pripažista savo nuomonę, bet konfliktuoja & 3 \\
\hline & & Pripažįsta savo ir kitų nuomonę & 5 \\
\hline & & $\begin{array}{l}\text { Noriai dalijasi duomenimis, informacija, žiniomis ir } \\
\text { patirtimi }\end{array}$ & 8 \\
\hline & & Kuria teigiamą mikroklimatą organizacijoje & 10 \\
\hline & \multirow[t]{5}{*}{ Atsakomybė } & Nepriima sprendimu & 0 \\
\hline & & Priima sprendimus, kai apibrèžtos problemos & 3 \\
\hline & & $\begin{array}{l}\text { Priima savarankiškus sprendimus, kai problemos } \\
\text { neapibrėžtos, o rezultatas kontroliuojamas }\end{array}$ & 5 \\
\hline & & $\begin{array}{l}\text { Priima savarankiškus sprendimus, kai problemos } \\
\text { neapibrèžtos, sprendimai lemia padalinio veiklos } \\
\text { rezultatą }\end{array}$ & 8 \\
\hline & & $\begin{array}{l}\text { Vadovauja kolektyviniam valdymo organui } \\
\text { sprendžiant problemas, susijusias su svarbiausiais } \\
\text { strateginiais klausimais }\end{array}$ & 10 \\
\hline & \multirow[t]{3}{*}{ Motyvacija dirbti } & Neturi motyvacijos dirbti & 0 \\
\hline & & Turi vidutinę motyvaciją dirbti & 5 \\
\hline & & Turi stiprią motyvaciją dirbti & 10 \\
\hline & \multirow{3}{*}{$\begin{array}{l}\text { Savarankiškumas } \\
\text { darbe }\end{array}$} & Taisyklèmis apibrežtas rutininis darbas & 3 \\
\hline & & $\begin{array}{l}\text { Užduotys apibrèžtos, bet reikalinga informacija iš } \\
\text { išorés }\end{array}$ & 7 \\
\hline & & $\begin{array}{l}\text { Savarankiškos užduotys reikalaujančios } \\
\text { kūrybiškumo, naujoviškumo, intuicijos, aukštojo } \\
\text { išsilavinimo, tikslaus vidinès ir išorinès terpès ryšių }\end{array}$ & 10 \\
\hline
\end{tabular}

Visų kokybinių veiksnių reikšmėms nustatyti pakanka tipinių darbuotojų apklausos duomenų, o veiksnių reikšmingumams - ekspertinės apklausos. Kiekybinių veiksnių duomenys iprastai kaupiami organizacijos informacinèje sistemoje. Svarbiausi veiksniai, turintys įtakos darbuotojo žinioms, išreikšti kiekybiškai ir kokybiškai, sujungiami i vieną bendrą rodikli $\left(D_{i}\right)$ taip: apskaičiuojama išreikštiniu $\left(m_{i}\right)$ ir neišreikštiniu $\left(n_{j}\right)$ darbuotojo žinių veiksnių dedamuju suma bei darbuotojo išreikštinių $\left(I_{i}\right)$ ir neišreikštinių $\left(N_{j}\right)$ žinių veiksnių suma (3.5, 3.6, 3.7 formulès):

$$
\begin{gathered}
I_{i}=\sum_{i=1}^{6} \gamma_{i} m_{i}, \\
N_{i}=\sum_{i=1}^{6} \delta_{i} n_{i}, \\
D_{i}=I_{i}+N_{i},
\end{gathered}
$$

čia $I_{i}$ - išreikštinių darbuotojo žinių veiksnių suma, $\gamma_{i}$ - išreikštinių darbuotojo žinių veiksnių dedamujų reikšmingumai, $m_{i}$ - išreikštinių darbuotojo žinių 
veiksnių dedamoji, $N_{i}$ - neišreikštinių darbuotojo žinių veiksnių suma, $\delta_{i}-$ neišreikštinių darbuotojo žinių veiksnių dedamujų reikšmingumai, $n_{i}-$ neišreikštiniu darbuotojo žinių veiksnių dedamoji, $i$ - rodiklio numeris, $D_{j}-$ darbuotojo žinių indeksas, $j$ - darbuotojo numeris.

Sudarius žinių vertinimo rodiklių sistemą, išskyrus pagrindinius veiksnius, turinčius įtakos darbuotojų žinių formavimuisi, kitas darbuotojo žinių vertinimo etapas - tinkamo daugiakriterinio vertinimo metodo parinkimas.

\subsection{Daugiakriterinių vertinimo metodų charakteristika}

Kompleksiniams uždaviniams spręsti mokslinèje literatūroje siūloma daugybè daugiakriterinio vertinimo metodų: nuo paprasčiausios vietų (rangų) sumos iki besiremiančių sudètingais matematiniais skaičiavimais (Ginevičius, Krivka 2009). Šie metodai leidžia įvertinti alternatyvas pagal jų požymius ir bendrus tikslus bei priimti geriausius sprendimus (E priedas).

Kiekvienas iš šių metodų pasižymi jam būdingu vertinimo procesu. V. Podvezko (2011) lygindamas SAW ir COPRAS metodus nustatè, kad COPRAS metodas leidžia tiksliau įvertinti skaičiavimo rezultatus. COPRAS ir TOPSIS metodus galima taikyti vienodai, vertinant pagal tą pačią tikimybę (Antucheviciene et al. 2010). I. Vinogradova (2015) atlikusi daugiakriterinių metodų stabilumo imitavimo tyrimą nustate, kad kuo didesnis imitacijų skaičius, tuo tikslesnis daugiakriterinio metodo stabilumo vertinimas. Atlikus milijoną imitaciju procentinè stabilumo išraiška intervaluose pasiskirsto taip: PROMETHEE - [65,8 \%-65,9\%], TOPSIS - [58,46 \%-58,54\%], SAW, COPRAS - [53,43\%-53,45\%], MOORA - [44\%-58\%], t. y. metodas patekęs i didesni procentinị intervalą yra stabilesnis.

Daugiakriteriniu metodu EDAS (angl. Evaluation based on Distance from Average Solution) vertinamas keletas prieštaringu rodiklių. EDAS metodo principas panašus i TOPSIS ar VIKOR metodų, kai geriausiai alternatyvai vertina atstumą nuo geriausio ir prasčiausio sprendimo, t. y. geriausia alternatyva turi mažesnį atstumą nuo geriausio sprendimo ir didesnį atstumą nuo prasčiausio. Tačiau, EDAS metodo rodiklių reikšmių vertinimo metu geriausia alternatyva lyginama su atstumu nuo vidutinio sprendimo (sprendinio), t. y. du ịverčiai: pirmas yra teigiamas atstumas nuo vidurkio (PDA - angl. positive distance from average), antrasis - neigiamas atstumas nuo vidurkio (NDA - angl. negative distance from average), kurie parodo skirtumus tarp kiekvienos iš alternatyvų ir vidutinio sprendimo (sprendinio). Šios abi reikšmès parodo, kad vertinama alternatyva yra geresnè arba blogesnè negu vidutinis sprendimas. 
ARAS metodas padeda nustatyti nagrinejjamų atnaujinimo alternatyvu efektyvumą lyginant su optimalia alternatyva, kurios parametrus nustato pats vertintojas, tai sudaro sąlygas išrinkti geriausią, suinteresuotos grupès poreikius tenkinančią, alternatyvą. Dél sudètingos logikos dominuojančiujų alternatyvų (outranking) PROMETHEE ir ELECTRE metodai yra retai taikomi. Šiuose metoduose vietoj ịprastų kriterijų normalizuotų reikšmių taikomos specialiai parinktų funkcijų (prioritetų, sutarimo ir nesutarimo) reikšmės. Funkcijų parametru nustatymo procese turi dalyvauti sprendimą priimantis asmuo (Podvezko 2012).

Daugelio tyreju (Podvezko 2008, Ginevičius, Krivka 2009, Tupènaitė 2010, Simanavičienè, Cibulskaitè 2015, Vinogradova 2015) praktika rodo, kad sumažinama taikomo daugiakriterinio vertinimo metodo subjektyvumo itaka, jei analizuojamas reiškinys vertinamas keliais metodais, galutinis tokiu būdu atlikto vertinimo rezultatas - taikytų kelių daugiakriterinių vertinimo metodų gautų rezultatų aritmetinis vidurkis.

3.11 lentelè. Vertinimo metodų kriterijai (sudaryta autorès)

Table 3.11. Criteria of evaluation methods (compiled by the author)

\begin{tabular}{|c|c|c|c|c|c|}
\hline Kriterijai & $\begin{array}{l}\text { Rezultatų } \\
\text { pastovumas } \\
\text { (Pastovūs (2)/ } \\
\text { Vidutiniai (1)/ } \\
\text { Nepastovūs } \\
\text { (0)) }\end{array}$ & 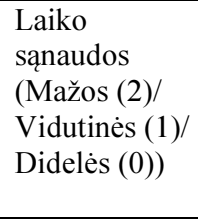 & $\begin{array}{l}\text { Paprastas } \\
\text { taikyti } \\
\text { (Paprastas (2)/ } \\
\text { Vidutinis (1)/ } \\
\text { Sudettingas } \\
\text { (0)) }\end{array}$ & $\begin{array}{l}\text { Ekspertu } \\
\text { apklausa } \\
\text { (Nereikalinga } \\
\text { (1)/ Reikalinga } \\
\text { (0)) }\end{array}$ & 急营 \\
\hline AHP & 1 & 1 & 2 & 0 & 4 \\
\hline ARAS & 1 & 1 & 1 & 0 & 3 \\
\hline COPRAS & 1 & 1 & 1 & 0 & 3 \\
\hline ELECTRE & 2 & 0 & 0 & 0 & 2 \\
\hline PROMETHEE & 2 & 0 & 0 & 0 & 2 \\
\hline MOORA & 1 & 1 & 1 & 1 & 4 \\
\hline SAW & 1 & 2 & 2 & 0 & 5 \\
\hline TOPSIS & 2 & 1 & 1 & 0 & 4 \\
\hline VIKOR & 1 & 1 & 1 & 1 & 4 \\
\hline EDAS & * & 2 & 1 & 1 & 4 \\
\hline $\begin{array}{l}\text { Pageidautinas } \\
\text { vertinimas }\end{array}$ & 2 & 2 & 2 & 1 & 7 \\
\hline
\end{tabular}

*Nera duomeny

Daugiakriterinių metodų duomenys yra stochastinès prigimties, ir jų neapibrēžtumas turi ịtakos taikomujų metodų vertinimų rezultatams. Bet koks matematinis metodas gali būti taikomas praktikoje, jei jis tenkina stabilumo sąlygą (Žukauskienė 2011). Matematinis metodas laikomas stabiliu, kai nedidelị parametrų svyravimą atitinka mažas rezultatų keitimasis. Darbuotojo žinioms 
vertinti tikslinga parinkti tokị metodą, kurio rezultatai yra pastovūs, sąnaudos laiko atžvilgiu - mažos, be to metodas būtų paprastas ir nesunkiai pritaikomas organizacijoje (3.11 lentelè).

Pažymètina, kad visais metodais galima vertinti alternatyvas išreikštas tiek kiekybiniais, tiek kokybiniais rodikliais, o kriterijai gali būti skirtingų matavimo dimensijų. Darbuotojo žinioms vertinti tikslinga pasirinkti SAW metodą, nes ji taikant patiriamos mažos laiko sąnaudos, be to ji paprasta taikyti, o rezultatai vidutiniškai pastovūs. Taikant SAW metodą reikalingas ekspertų vertinimas darbuotojo žinių veiksnių bloko rodiklių reikšmingumams nustatyti. Organizacijai, turinčiai tikslą tam tikriems darbuotojo žinių veiksniams teikti pirmumą, šio metodo taikymas suteiks tokią galimybę. AHP, TOPSIS, MOORA ir VIKOR metodai atitinka keliamą stabilumo reikalavimą ir jų jungtinis taikymas sumažintų rezultatų subjektyvumą. AHP metodo taikymas sudarytų sąlygas struktūruotoms darbuotojo žinioms ir rodiklių pirmumui ịvertinti ekspertiniu būdu. Be to, jei veiksnių reikšmingumas traktuojamas pagal organizacijos veiklos specifiką, t. y. jeigu organizacijai reikalingi turintys aukštaji išsilavinimą darbuotojai, tai šio veiksnio reikšmingumą ekspertai galès parinkti didesni nei kitiems veiksniams. TOPSIS metodas pasižymi rezultatų pastovumu, tačiau, metodika priskiriama prie vidutiniškai sunkaus pritaikymo organizacijoje. MOORA ir VIKOR metodikoje nèra ekspertų vertinimo, todèl išvengiama subjektyvumo, atsirandančio dèl skirtingos ekspertų kompetencijos, vertybių sistemos, patirties. EDAS metodas - naujas, todèl nèra duomenų apie rezultatų stabilumą skaičiuojant šiuo metodu, bet jis turi dideli privalumą, t. y. nereikia skaičiuoti didžiausios ir mažiausios rodiklių reikšmès. Kadangi metodas skirtas alternatyvų sąveikai, siūloma skaičiuoti vidurkị ir du dydžius - teigiamą ir neigiamą atstumus nuo vidurkio. Pažymėtina, kad kai kuriais atvejais neįmanoma apskaičiuoti maksimalios rodiklio vertès arba iškyla sunkumų jas skaičiuojant (pavyzdžiui, darbuotojo darbo atlyginimą), todèl EDAS metodo taikymas būtų tinkamas ir tikslingas darbuotojo žinioms vertinti.

\section{5. Žinių sinergijos komponentụ normalizavimas}

Kiekvienas daugiakriterinio vertinimo uždavinys turi savo privalumų, taikymo ypatumų ir apribojimų: renkantis konkretų metodą, svarbu atsižvelgti ị rodiklių reikšmių transformavimo, normalizavimo ir neigiamų reikšmių pertvarkymo reikalavimus, kriterijų svorio poveikị vertinimui, vertinimo kriterijų pobūdị (maksimizuojamieji ir minimizuojamieji) bei kitas aplinkybes (Podvezko 2008). Kadangi vertinimui būtini duomenys gali būti skirtingų skalių, būtina juos normalizuoti, t. y. sulyginti jų reikšmes, kad galima būtų apskaičiuoti galutinę reikšmę. 
Pradinès reikšmės normalizuojamos pagal formulę:

$$
w_{i j}=\frac{m_{i j}}{\sum_{j=1}^{n} m_{i j}},
$$

čia $w_{i j}-j$-osios alternatyvos i-ojo kriterijaus normalizuotoji rodiklio reikšmè, $m_{i j}-$ $j$-osios alternatyvos i-ojo kriterijaus rodiklio reikšme, $\sum_{j=1}^{n} m_{i j}-j$-osios alternatyvos $i$-ojo kriterijaus rodiklių reikšmių suma.

Tam, kad normalizuotume veiksnių reikšmes (t. y. pateikti vertinimo rezultatus procentine išraiška), taikomas toks reikalavimas:

$$
\sum_{i=1}^{j} w_{i j}=1 \text {, }
$$

čia $w_{i j}>0$ - normalizuotos veiksnių reikšmès.

Pavyzdžiui, darbo užmokesčio ịverčiui apskaičiuoti būtina atsižvelgti, jog skirtingose šalyse vartojama skirtinga valiuta, todèl būtina darbuotojo darbo užmokesčio dydžio vertę konvertuoti i tokio pat tipo valiutą, o tada redukuoti i santykinius dydžius, atliekant normalizavimo procedūras pagal 3.8 formulę.

\subsection{Ekspertų atrankos kriterijai ir nuomonių suderinamumas}

Daugelyje žmogaus sprendžiamų uždavinių yra problemų, kurioms išspręsti nepakanka skaitinių duomenų arba neįmanoma išmatuoti tiriamojo objekto. Tada parenkami specialistai, papildantys duomenis savo įvertinimu. Be abejonès, norint priimti pagrịstą sprendimą, reikia remtis patirtimi, žiniomis bei intuicija (Orlov 2002). Vertinant veiksnius, jų naudojimo tinkamumą, pagrindimą ar svarbą, dažniausiai nustato kvalifikuoti vertinimo srities specialistai - ekspertai (lot. expertus - patyręs). Tai žmonès, turintys specialių konkrečios srities žinių ir igūdžiu (IPCC 2000, Serafinas 2014). Eksperto parinkimo problema yra viena iš sunkiausių teoriškai ir praktiškai, kadangi asmenys, gebantys vertinti kuri nors požymį, nèra vienodos kompetencijos, skirtingos ir jų vertybės. Ekspertai parenkami, remiantis jų charakteristikomis, susijusiomis su profesine kompetencija: darbo patirtimi, stažu, moksliniu laipsniu ir moksline veikla, gebejjimu spręsti konkrečias atitinkamos srities problemas (Beshelev, Gurvitch 1974, Hora 2009).

Taikomi ir kiti ekspertu kompetencijos nustatymo ir atrankos būdai: dokumentinis (kompetencijos vertinimas socialinių-demografinių duomenų pagrindu); eksperimentinis (kompetencijos vertinimas testavimo, ankstesnès ekspertu veiklos efektyvumo patikrinimo pagrindu). Ekspertams užduodami paprasti tekstiniai klausimai, kurių rezultatas turi sutapti su tikrais rezultatais. Šis 
būdas naudojamas retai dèl klausimų sistemos kūrimo sunkumo bei ekspertinių uždavinių vertinimo subjektyvumo. Dar gali būti naudojamas balsavimas (kompetencijos vertinimas atestavimo pagrindu, kai asmenis rekomenduoja grupè) ir savęs vertinimas (savo kompetencijos vertinimas atliekant savianalizę) (Tidikis 2003). Ekspertu apklausos metodikų yra ịvairių nuo tyrejo bendradarbiavimo iki individualios ar grupinès anketinès apklausos (3.12 lentelè).

3.12 lentelè. Ekspertų apklausos metodikų grupès (sudaryta autorès pagal Orlov 2002, Tidikị 2003, Vinogradovą 2015)

Table 3.12. Method groups for expert survey (compiled by the author based on Orlov 2002, Tidikis 2003, Vinogradova 2015)

\begin{tabular}{|c|c|c|}
\hline Grupè & Tipas & Aprašymas \\
\hline \multirow[t]{2}{*}{$\begin{array}{l}\text { Pagal ekspertǔ } \\
\text { tarpusavio ryši }\end{array}$} & Akivaizdūs & $\begin{array}{l}\text { Tyrejas dirba kartu su } \\
\text { ekspertais }\end{array}$ \\
\hline & Neakivaizdūs & $\begin{array}{l}\text { Ekspertai vertina problemą } \\
\text { nepriklausomai nuo tyrèjo }\end{array}$ \\
\hline \multirow{2}{*}{$\begin{array}{l}\text { Pagal vertinimų } \\
\text { suderinimo } \\
\text { procedūrą }\end{array}$} & Vienkartiniai & $\begin{array}{l}\text { Problemą ekspertai vertina } \\
\text { vieną kartą }\end{array}$ \\
\hline & Daugkartiniai & $\begin{array}{l}\text { Tikrinamas ekspertų nuomonių } \\
\text { suderinamumas ir kartojamas } \\
\text { ekspertu vertinimas }\end{array}$ \\
\hline \multirow[t]{4}{*}{$\begin{array}{l}\text { Pagal ekspertų } \\
\text { skaičių }\end{array}$} & Individualūs metodai & $\begin{array}{l}\text { Ekspertas vertina vienas ir } \\
\text { išreiškia savo nuomonę } \\
\text { nepriklausomai nuo kitų } \\
\text { ekspertų }\end{array}$ \\
\hline & Grupiniai metodai & $\begin{array}{l}\text { Sprendžiant sudetingas, plataus } \\
\text { masto problemas ekspertai } \\
\text { kartu rengia medžiagą arba } \\
\text { priima sprendimą }\end{array}$ \\
\hline & $\begin{array}{l}\text { Ranguojami, vertinant objektą } \\
\text { santykineje skalëje }\end{array}$ & $\begin{array}{l}\text { Objektai ranguojami lyginimo } \\
\text { būdu }\end{array}$ \\
\hline & $\begin{array}{l}\text { Ranguojami, vertinant objektą } \\
\text { absoliutinejje (skaitineje) } \\
\text { skalejje }\end{array}$ & $\begin{array}{l}\text { Pasirenkama konkreti } \\
\text { vertinimo skale }\end{array}$ \\
\hline \multirow{2}{*}{$\begin{array}{l}\text { Pagal iteraciju } \\
\text { skaičių }\end{array}$} & Vieno žingsnio & Procedūra nekartojama \\
\hline & Iteraciniai & $\begin{array}{l}\text { Siekiant tikslumo procedūra } \\
\text { kartojama }\end{array}$ \\
\hline
\end{tabular}

Priklausomai nuo reikalavimų, keliamų gaunamai informacijai, ekspertų vertinimas gali būti ịvairios formos - nuo profesionalių interviu arba neakivaizdinès individualios apklausos anonimine anketa iki atviros grupinès šių asmenų diskusijos, nagrinejjant problemą. Ekspertiniai duomenų gavimo metodai klasifikuojami ị: pasyvu vertinimą, kai ekspertas neatlieka vertinimo pats, 
ekspertai yra stebimi, o vèliau jų samprotavimai yra analizuojami; aktyvu vertinimą, kai vertinimą atlieka pats ekspertas (Orlov 2002). Praktikoje dažnesni aktyvūs ekspertinio vertinimo duomenu gavimo metodai (3.13 lentelè).

3.13 lentelè. Aktyvių vertinimo metodų klasifikacija (sudaryta autorès pagal Vinogradovą 2015)

Table 3.13. Classification of active evaluation methods (compiled by the author based on Vinogradova 2015)

\begin{tabular}{|c|c|c|}
\hline Metodas & Aprašymas & Autoriai \\
\hline Asociacijų & Panašių savybių objekto tyrimas & $\begin{array}{l}\text { Beshelev, } \\
\text { Gurvitch } 1974\end{array}$ \\
\hline Porinio lyginimo & Alternatyvų lyginimas poromis & $\begin{array}{l}\text { Beshelev, } \\
\text { Gurvitch } 1974\end{array}$ \\
\hline $\begin{array}{l}\text { Laisvasis } \\
\text { interviu }\end{array}$ & $\begin{array}{l}\text { Individualus ekspertizés metodas, kai tyrejas } \\
\text { asmeniškai kreipiasi i jam žinomus specialistus } \\
\text { dèl konsultacijos be iš anksto sudaryto griežto } \\
\text { pokalbio plano }\end{array}$ & Tidikis 2003 \\
\hline $\begin{array}{l}\text { Nuomonių } \\
\text { rinkimo }\end{array}$ & $\begin{array}{l}\text { Ekspertams išsiunčiamos arba išdalijamos } \\
\text { specialiai parengtos apklausos anketos, kuriose } \\
\text { jie privalo išsamiai pareikšti savo nuomonę del } \\
\text { pateiktų klausimų esmès }\end{array}$ & Tidikis 2003 \\
\hline Smegenų ataka & $\begin{array}{l}\text { Kolektyvinis akivaizdus ekspertų darbas, kurio } \\
\text { tikslas - rasti variantus sunkiai teorinei arba } \\
\text { praktinei problemai išspręsti (Tidikis, 2003) }\end{array}$ & Tidikis 2003 \\
\hline $\begin{array}{l}\text { Formalizuota } \\
\text { apklausa }\end{array}$ & $\begin{array}{l}\text { Respondentai gauna smulkią anketą su } \\
\text { uždaraisiais arba pusiau uždaraisiais klausimas, } \\
\text { gauta informacija analizuojama ir kokybiškai, } \\
\text { ir kiekybiškai }\end{array}$ & Tidikis 2003 \\
\hline Skalės vertinimų & $\begin{array}{l}\text { Skirtas kokybinei informacijai gauti, naudojant } \\
\text { ekspertu požiūrị i ekspertizès dalyką, vertinimą } \\
\text { pagal skalę (nominalią, ranginę, metrinę) }\end{array}$ & Tidikis 2003 \\
\hline Delfi & $\begin{array}{l}\text { Paremtas suderinta grupés ekspertų nuomone, } \\
\text { priimta nepriklausomos anoniminés ekspertų } \\
\text { apklausos būdu; apklausa kartojama kelis } \\
\text { kartus, kiekviename etape ekspertus } \\
\text { informuojant apie ankstesniu apklausų } \\
\text { rezultatus }\end{array}$ & $\begin{array}{l}\text { Beshelev, } \\
\text { Gurvitch 1974, } \\
\text { Butakova } 2010\end{array}$ \\
\hline
\end{tabular}

Gautą iš ekspertų informaciją racionaliai panaudoti įmanoma tik pertvarkytą ir parengtą tolesnei analizei bei sprendimams. Informacijos pobūdis priklauso nuo tiriamų objektų savybių. Paplitę informacijos apdorojimo būdai yra du: rangavimas ir tiesioginio vertinimo metodas (Tidikis 2003). 
Taikant daugiakriterinius vertinimo metodus reikia patikrinti ir patvirtinti ekspertų nuomonių suderinamumo lygi. Siekiant numatyto ekspertų vertinimo suderinamumo skaičiuojamas Kendall konkordancijos koeficientas.

Skaičiuojant konkordancijos koeficientą $W$ ekspertų vertinimai ranguojami. Tarkime, turime $e$ ekspertų, kurie ịvertino $m$ alternatyvų (rodiklių ar veiksnių). Pirmiausia kiekviename stulpelyje esančios reikšmès keičiamos rangais. Tikrinama, ar ekspertų nuomonès dera tarpusavyje.

Koeficiento idejja susieta su kiekvieno rodiklio rangų suma visų ekspertų atžvilgiu:

$$
W=\frac{12 \kappa}{p^{2} m\left(m^{2}-1\right)},
$$

čia $p$ - ekspertų skaičius, $m$ - veiksnių skaičius, $\mathbf{N}$ - rodiklių rangų sumų nuokrypių nuo jų bendro vidurkio kvadratų suma.

Jeigu konkordacijos koeficiento reikšmė artima vienetui, tai ekspertų vertinimai neprieštaringi, jei vertinimai labai skiriasi - $W$ reikšmė yra arti nulio. Ekspertų nuomonių suderinamumas laikomas pakankamu, jei konkordancijos koeficiento $W$ reikšmè siekia $0,6-0,7$.

\subsection{Trečiojo skyriaus išvados}

1. Organizacijos žinių sinergijos vertinimo modelis kuriamas naudojant daugiakriterinių sprendimų analizès teorija grịstais principais: tikslingumas, suprantamumas, matuojamumas, nepertekliškumas, vertinimo nepriklausomumas, išsamumo ir glaustumo balansas, operacionalumas, paprastumo ir sudètingumo balansas.

2. Darbuotojo žinioms vertinti, tikslinga veiksnius suskirstyti i du blokus: išreikštines ir neišreikštines žinias. Šiems žinių blokams suteikti reikšmingumus, t. y. išreikštinių žinių $(\alpha)$ ir neišreikštinių žinių $(\beta)$ reikšmingumo koeficientus. Išreikštinių ir neišreikštinių žinių blokai skirstomi i veiksnius, kurie savo ruožtu i dedamąsias.

3. Darbuotojų žinių veiksnių sistemos sudarymas yra sudètingas procesas, nes tyrejjai, priklausomai nuo tyrimo objekto ar nagrinejjamo reiškinio, išrenka tik tam objektui tinkamus ir svarbius veiksnius. I sistemą gali būti įtrauktas ribotas veiksnių skaičius, kai jų per daug, neįmanoma tiksliai įvertinti kiekvieno veiksnio poveikio galutiniam rezultatui. Atlikus darbuotojų žinių veiksnių analizę gaunama žinių vertinimo veiksnių aibè apjungianti 27 veiksnius. Siekiant įvertinti organizacijos darbuotojų žinių sinergiją, išgryninti kiekvieno veiksnio dedamosios ir įverčiai bei pateiktas darbuotojo žinių vertinimo algoritmas. 
4. Pažymėtina, kad daugiakriteriniais metodais galima vertinti alternatyvas išreikštas tiek kiekybiniais, tiek kokybiniais rodikliais, o kriterijai gali būti skirtingų matavimo dimensijų. Darbuotojo žinioms vertinti siūloma taikyti SAW metodą, dèl patiriamų mažų laiko sąnaudų, be to jị paprasta taikyti. AHP, TOPSIS, Moora ir Vikor metodai atitinka keliamą stabilumo reikalavimą ir jų jungtinis taikymas sumažintų rezultatų subjektyvumą. AHP metodo taikymas sudarytų sąlygas struktūruotoms darbuotojo žinioms ir rodiklių pirmumui ìvertinti ekspertiniu būdu.

5. Darbuotojo žinių, ryšių tarp darbuotojų, gebejjimo įgyti žinių, naudotis ir dalintis jomis tyrimai ir, apskritai, organizacijos žinių sinergijos vertinimas yra labai svarbūs organizacijoms ir yra naudingi visų organizacijų darbuotojų žinių plètrai bei naujų žinių kūrimui. 



\section{4}

\section{Organizacijos žinių sinergijos vertinimo modelio empirinio tyrimo metodologija}

Šiame skyriuje pateikta organizacijos žinių sinergijos vertinimo modelio empirinio tyrimo metodologija: pateiktos komponentu - organizacijos darbuotojų žinių ir darbuotojų ryšių - vertinimo metodikos, atlikti empiriniai tyrimai, kurių metu tarptautine ekspertų grupe ịvertino darbuotojų žinių veiksnių, jų dedamujų reikšmingumus 5-iose Lietuvos, Australijos bei Airijos organizacijose, o šių organizacijų darbuotojai užpildè anketas, kuriomis remiantis apskaičiuotos kiekvieno darbuotojo žinios bei integruotas įvertis. Surinkti duomenys apdoroti, vizualizuoti bei pateikti apibendrinti vertinimo rezultatai, jų rekomendacijos.

Organizacijos darbuotojų žinių sinergijos vertinimą sudaro organizacijos darbuotojų žinių vertinimas, ryšių tarp darbuotojų vertinimas bei šių vertinimų rezultatų integracija, siekiant nustatyti galutinį žinių sinergijos įvertį.

Organizacijos darbuotojų žinių sinergijos vertinimui taikytas sisteminis požiūris, t. y. išskirti komponentai, veiksniai ir dedamosios. Išskirtų komponentų ir žinių sinergijos turinio analizè padeda greičiau nustatyti silpnybes bei stiprybes ir suteikia aiškumo priimant ịvairius sprendimus. Sisteminio požiūrio taikymas sudaro sąlygas išsamiai vertinti darbuotojų ryšius ir bendradarbiavimą, kurio metu 
sukurta žinių sinergija sudaro sąlygas formuotis tokiai organizacijai, kurioje darbuotojų tarpusavio bei padalinių bendradarbiavimas leidžia pasiekti didesnių rezultatu, nei dirbant atskirai.

Vertinant organizacijos darbuotojų žinias visų pirma sudaroma žinių veiksnių sistema, atrenkami veiksniai pagal jų svarbą ir itaką žinioms, po to remiantis M. Polanyi (1962, 1967), I. Nonaka ir H. Takeuchi (1995) veiksniai grupuojami i išreikštinių ir neišreikštinių žinių blokus, o šiems veiksniams įvertinti naudojami daugiakriteriniai SAW ir AHP metodai. Bendravimas apibrezžiamas kaip asmenų betarpiškų santykių sritis, t. y. asmeninè ir socialinè sąsaja su bendradarbiais, kuri atsiranda dirbant ir siekiant bendro tikslo (Anzenbacheris 1992). Remiantis bendravimo apibrèžimu, nustatomi darbuotojų ryšių tipai, o naudojant kombinatorikos taisykles ir grafų teoriją, apskaičiuojami ryšiai. Žinių sinergijos dedamujų îverčiai integruojami ị galutini žinių sinergijos įverti (4.1 lentelè).

4.1 lentelè. Organizacijos žinių sinergijos vertinimo metodologija (sudaryta autorès) Table 4.1. Organisation knowledge synergy evaluation methodology (compiled by the author)

\begin{tabular}{|c|c|c|}
\hline Žingsniai & Naudojamas metodikos & Metodikų etapai \\
\hline $\begin{array}{l}\text { Organizacijos } \\
\text { darbuotojų žinių } \\
\text { vertinimas }\end{array}$ & $\begin{array}{l}\text { Organizacijos } \\
\text { darbuotoju žiniu } \\
\text { vertinimo metodika }\end{array}$ & $\begin{array}{l}\text { 1. Pasiruošimas vertinimui; } \\
\text { 2. Konsultavimas; } \\
\text { 3. Vertinimas; } \\
\text { 4. Rezultatų apibendrinimas }\end{array}$ \\
\hline Ryšių tipų vertinimas & $\begin{array}{l}\text { Ryšių tipu vertinimo } \\
\text { metodika }\end{array}$ & $\begin{array}{l}\text { 1. Nustatomi organizacijos } \\
\text { ryšiu tipai; } \\
\text { 2. İvertinami ryšiai }\end{array}$ \\
\hline $\begin{array}{l}\text { Ivertintų organizacijos } \\
\text { žiniu sinergijos } \\
\text { komponentu } \\
\text { apjungimas ị galutinị } \\
\text { organizacijos žinių } \\
\text { sinergijos iverti }\end{array}$ & $\begin{array}{l}\text { Organizacijos žinių } \\
\text { sinergijos komponentų } \\
\text { integravimo metodika }\end{array}$ & $\begin{array}{l}\text { 1. Darbuotojų ịverčių } \\
\text { integravimas; } \\
\text { 2. Ryšių îverčių integravimas; } \\
\text { 3. Integruotų ir galutinio } \\
\text { iverčių interpretacija }\end{array}$ \\
\hline
\end{tabular}

Taikytų metodikų detalus aprašymas pateikiamas tolesniuose poskyriuose.

Skyriaus tematika paskelbtas vienas autorès straipsnis (Skačkauskienė, Katinienè 2017). 


\subsection{Organizacijos žinių sinergijos komponento - ryšiai tarp darbuotojų - tyrimo rezultatai}

Vertinant organizacijos darbuotojų žinių sinergijos komponentą - ryšius tarp darbuotojų - pirmiausia tikslinga nustatyti ryšiu tipus organizacijoje, o po to apskaičiuoti ryšius tarp darbuotojų ar jų grupių.

Darbuotojams bendraujant ir bendradarbiaujant bei dalijantis žiniomis galimi ryšių tipai pagal darbuotojų žinių grižtamumo lygị ir darbuotojų skaičiu grupejje, t. y. kai vienas darbuotojas dalijasi žiniomis su kitu darbuotoju, abu darbuotojai dalijasi žiniomis, vienas darbuotojas dalijasi žiniomis su grupe darbuotojų, du ir daugiau darbuotojų dalijasi žiniomis su grupe darbuotojų. Ištyrus ryšių tarp darbuotojų vertinimo galimybes (2.5.1. poskyris) ir atsižvelgiant ị ryšių tipus bei efektyvių ryšių skaičiavimo metodus (3.2. poskyris) skirtingo tipo ryšiams tarp darbuotojų skaičiuoti taikytina atitinkama formulè (4.2 lentelè).

4.2 lentelè. Ryšių tarp darbuotojų tipai tirtose organizacijose (sudaryta autorès)

Table 4.2. Types of relations among employees in researched organisations (compiled by the author)

\begin{tabular}{|c|c|c|c|c|c|}
\hline Ryšių tipai & $\begin{array}{l}\text { VI „,X } \\
\text { miškų } \\
\text { uredija“ }\end{array}$ & $\begin{array}{l}\text { UAB } \\
\text { „Skrema“ }\end{array}$ & $\begin{array}{l}\text { "Geelong } \\
\text { Garage } \\
\text { Doors" }\end{array}$ & „Kiverco“ & „Flowerbox“ \\
\hline \multicolumn{6}{|c|}{ Vienpusiai ryšiai } \\
\hline $\begin{array}{l}\text { tarp vadovo ir } \\
\text { pavaldžių } \\
\text { darbuotojų }\end{array}$ & + & + & + & + & - \\
\hline $\begin{array}{l}\text { tarp grupès } \\
\text { darbuotojų } \\
\text { (cecho ar } \\
\text { konvejerinès } \\
\text { gamybos } \\
\text { darbuotojų } \\
\text { grupejje) }\end{array}$ & - & - & - & + & - \\
\hline $\begin{array}{l}\text { tarp vadovo ir } \\
\text { grupės } \\
\text { darbuotojų }\end{array}$ & + & - & - & - & - \\
\hline $\begin{array}{l}\text { tarp vadovo ir } \\
\text { tarp grupès } \\
\text { darbuotojų }\end{array}$ & - & - & - & - & - \\
\hline
\end{tabular}


4.2 lentelès pabaiga

\begin{tabular}{|c|c|c|c|c|c|}
\hline Ryšių tipai & $\begin{array}{l}\mathrm{VI}, \text { „X } \\
\text { mišku } \\
\text { urèdija“ }\end{array}$ & $\begin{array}{l}\text { UAB } \\
\text { „Skrema“ }\end{array}$ & $\begin{array}{l}\text { "Geelong } \\
\text { Garage } \\
\text { Doors" }\end{array}$ & „Kiverco“ & „Flowerbox“ \\
\hline \multicolumn{6}{|c|}{ Vienpusiai ryšiai } \\
\hline $\begin{array}{l}\text { grupèje tarp } \\
\text { grupès } \\
\text { darbuotojų }\end{array}$ & - & - & - & - & - \\
\hline \multicolumn{6}{|c|}{ Abipusiai ryšiai } \\
\hline $\begin{array}{l}\text { tarp vadovo ir } \\
\text { pavaldžių } \\
\text { darbuotojų }\end{array}$ & + & + & + & + & - \\
\hline $\begin{array}{l}\text { tarp grupès } \\
\text { darbuotojų } \\
\text { (cecho ar } \\
\text { konvejerinès } \\
\text { gamybos } \\
\text { darbuotojų } \\
\text { grupeje) }\end{array}$ & + & + & + & - & - \\
\hline $\begin{array}{l}\text { tarp vadovo ir } \\
\text { grupès } \\
\text { darbuotojų }\end{array}$ & + & - & + & + & + \\
\hline $\begin{array}{l}\text { tarp vadovo ir } \\
\text { tarp grupès } \\
\text { darbuotojų }\end{array}$ & + & - & + & + & - \\
\hline $\begin{array}{l}\text { grupèje tarp } \\
\text { grupès } \\
\text { darbuotojų }\end{array}$ & + & + & + & + & + \\
\hline
\end{tabular}

Čia + yra tokio tipo ryšiai tarp darbuotojų, - nèra tokio tipo ryšių tarp darbuotojų.

$\mathrm{VI}$ „X miškų urèdija“ nustatyti septynių tipų ryšiai tarp darbuotojų: vienpusiai kelio ryšiai tarp vadovo ir pavaldžių darbuotojų (13), tarp vadovo ir tarp grupès darbuotojų (10), abipusiai ryšiai tarp vadovo ir pavaldžių darbuotojų (26), tarp grupès darbuotojų (cecho darbuotojų) (90), tarp vadovo ir grupès darbuotojų (20), tarp vadovo ir tarp grupés darbuotojų, t. y. girininkų ir girininkijų narių (120) ir grupeje tarp grupès darbuotoju, t. y. projektinè grupe, kurioje buvo 5 nariai (62). Galutinis ryšių skaičius yra 341. 
UAB „Skrema“ nustatyti trijų tipų ryšiai tarp darbuotojų: vienpusiai kelio ryšiai tarp vadovo ir pavaldžių narių (2), abipusiai grupinio kelio ryšiai, t. y. vadovo su pavaldžiais jam darbuotojais (6) ir cecho viršininko su jam pavaldžiais cecho darbuotojais (42), ryšiai grupeje tarp grupès darbuotojų, t. y. projektinè grupè, kurioje yra 3 nariai (14). Galutinis ryšiu skaičius -64 .

"Geelong Garage Doors“ nustatyti keturių tipų ryšiai tarp darbuotojų: vienpusis kelio ryšys, t. y. tarp vadovo ir pavaldžių narių (3), abipusiai grupinio kelio ryšiai, t. y. vadovo su pavaldžiais jam darbuotojais (20), ryšiai vadovo su jam pavaldžiais cecho darbuotojais (72), ryšiai grupejje tarp grupès darbuotojų, t. y. projektinè grupè, kurioje yra 3 nariai (14). Galutinis ryšių skaičius - 99 .

„Kiverco“ nustatyti šešių tipų ryšiai tarp darbuotojų: vienpusiai ryšiai tarp vadovo ir pavaldžių darbuotojų (20), ryšiai tarp cecho darbuotojų (135), abipusiai ryšiai tarp vadovo ir pavaldžiu narių, t. y. vadovo su padalinių vadovais (14), ryšiai tarp vadovo ir grupès darbuotoju (150), ryšiai tarp vadovo ir tarp grupès darbuotojų (140), ryšiai tarp grupių narių (124), t. y. administracija, braižytojai, cecho darbuotojai. Galutinis ryšių skaičius yra -583 .

„Flowerbox“ nustatyta abipusio tipo dveji ryšiai tarp darbuotojų: abipusiai ryšiai, t. y. vadovo su grupès darbuotojais (12), abipusiai ryšiai, t. y. tarp darbuotojų (24). Galutinis ryšių skaičius -36 .

\subsection{Organizacijos darbuotojų žinių vertinimo metodụ parinkimo pagrindimas}

Šiuolaikinių organizacijų svarbiausiu ir pagrindiniu ištekliumi yra žinios. Siekiant efektyvaus jų naudojimo būtina žinių turinio analizè, žinių procesų valdymas bei žinių atnaujinimas. Organizacijos priverstos nuolat stebèti pokyčius, vertinti darbuotojų žinias, kvalifikaciją, gerinti darbo sąlygas, kurti tokią aplinką, kurioje darbuotojai noriai dalintųsi turimomis žiniomis, nešančiomis neabejotiną naudą organizacijai ir sudarančiomis sąlygas joms transformuotis i naujas žinias. C. Phelps et al. (2012) teigia, jog 1970 m. - 5-eriuose žurnalų, publikuojančiu vadybos, ekonomikos, psichologijos ir sociologijos straipsnius, pavadinimuose buvo naudojamas žodis ,žinios“, o 2009 m. - 35-eriuose. Tokius pokyčius šie tyrejjai sieja su didejančiu žinių poreikiu, atsiradusiais socialiniais tinklais, sudarančiais galimybę asmenims ir asmenų grupems gauti, perduoti, pritaikyti ir kurti žinias. J. Singh, L. Fleming (2010) teigia, jog asmenų tarpusavio bendradarbiavimas pagerina naujai sukurtų žinių kokybę bei organizacijų ekonominę vertę.

Daugelis tyreju - M. Šćepanović et al. (2016), B. J. Doyle et al. (2017) biologijoje, ekologijoje bei medicinoje, G. H. Popescu et al. (2016) ekonomikoje, 
M. Birasnav (2014), U. Andersson et al. (2016), A. Trusculescu et al. (2016), M. Kržin et al. (2017) vadyboje, C. Wringe (2015), D. Wood (2016), D. Wood et al. (2017) filosofijoje - aptaria žinių naudą bei jų valdymą, bet įrankių joms tirti ir vertinti stokojama. Tyrimų apie žinių vertinimo trūkumą atspindi A. Mardani et al. (2015) atlikta analizè - iš tirtų tik 5-iuose straipsniuose žinių valdymo problemoms spręsti taikomi daugiakriteriniai metodai. Skirtingiems uždaviniams spręsti pasiūlyta pačių ịvairiausių būdų, sukurta daug skirtingų daugiakriterinių metodų, besiremiančių ịvairiais matematiniais skaičiavimais, todèl atsiranda sumaištis dèl metodo parinkimo ir taikymo žinių vertinimui. Daugelis tyrèjų (Ha, Krishnan 2008) teigia, jog vertinimo metodai, be to, kad būtų paprasti ir lengvai suprantami, dar ir, taikant juos, turètų būti gaunami pakankamai tikslūs rezultatai, todèl darbuotojo žinioms vertinti tikslinga parinkti tokị metodą, kurio rezultatai būtų pastovūs, sąnaudos laiko atžvilgiu - mažos, be to metodas turètų būti nesunkiai pritaikomas organizacijoje. Keliamus reikalavimus labiausiai atitinka SAW metodas (Skačkauskienè, Katinienè 2017), kuri taikant gaunamas apibendrintas ivertis tiksliai atspindi kiekybinių daugiakriterinių metodų idèją- sujungti darbuotojų žinių veiksnius ir jų dedamąsias i apibendrinantị ịverti. Siekiant ištirti organizacijos darbuotojų žinias taip pat tikslinga taikyti ir AHP metodą - jo taikymas sudaro sąlygas struktūruotoms žinioms ir rodikliu pirmumui ịvertinti ekspertiniu būdu. Iš daugelio analizuotų daugiakriterinių metodų, išskirtini ir MOORA bei VIKOR, kurie tinkami organizacijos darbuotojų žinių vertinimo sistemos sudarymui ir jos optimizavimui. Šių metodų - SAW, AHP, MOORA ir VIKOR - taikymas leidžia nustatyti organizacijos darbuotojų žinių silpnybes ir stiprybes, vertinant žinių veiksnius bei jų dedamąsias, užtvirtinant rezultatų stabilumą ir sudaro sąlygas kompleksiškai ịvertinti darbuotojo žinias. Esant galimybei tikslinga darbuotojo žinių vertinimui taikyti SAW, AHP, MOORA ir VIKOR metodus kaip rinkini, taip išvengiant vertinimo subjektyvumo, be to, tokio vertinimo rezultatai yra naudingi darbo išteklių valdymo tobulinimui bei jie gali suteikti papildomos naudingos informacijos apie organizacijos darbuotojų potencialą.

Darbuotojo žinios yra daugialypès, susidedančios iš daugelio veiksnių: kvalifikacijos tobulinimo, išsilavinimo, technologijų naudojimo darbe, profesinès patirties, pareigų lygio, darbuotojo darbo užmokesčio, darbo sudètingumo, darbuotojo įtakos organizacijos tikslų igyvendinimui, darbo kultūros, atsakomybès, motyvacijos dirbti, savarankiškumo darbe, o šie dar ir iš dedamujų. Tokio sudètingo reiškinio - organizacijos darbuotojų žinių vertinimui, tikslinga taikyti daugiakriterinius vertinimo metodus. Atlikus daugiakriterinių metodu analizę, nustatyta, kad darbuotojų žinių vertinimui tinkamiausi metodai yra: SAW - rodiklio reikšmé ir jo svoris sujungiamas i vieną dydi (Podvezko 2011, Hwang, Yoon 2012); AHP - tai komponentų struktūrizavimas ị hierarchiją, atsižvelgiant ì komponentų svarbumą; MOORA - grindžiamas daugiatikslio 
optimizavimo santykio dydžio analize, susidedančia iš dviejų dalių: santykių sistemos ir atskaitos taško teorijos taikymu (Stankevičienè, Pilelyte 2015); VIKOR - kompromisinis rangavimo metodas, skirtas sudètingų daugiakriteriniu sistemu optimizavimui (Opricovic, Tzeng 2002, 2004). SAW ir AHP metodai taikytini darbuotojų žinių veiksnių ir jų dedamujų vertinimui. MOORA ir VIKOR metodai tinkami darbuotojų žinių veiksnių sistemos sudarymui, t. y. svarbiausių veiksnių bei jų dedamujų atrinkimui ị bendrą vertinimo sistemą.

\subsubsection{Organizacijos darbuotojų žinių vertinimo metodika}

Siekiant atlikti organizacijos darbuotojų žinių vertinimą, taikant daugiakriterinio vertinimo metodus, sudarytas algoritmas iš keturių etapų (4.1 pav.) Pirmasis etapas skirtas pasiruošimui, t. y. susipažinimas su vadovybe, organizacijos struktūra, žinių tyrimo svarbos ir numatomų rezultatų poreikio aptarimas. Šiame etape būtinas ekspertų, atrinktų pagal tam tikrus kriterijus, grupès ir veiksnių rinkinio sudarymas. Antrasis etapas skirtas konsultavimui, t. y. pokalbiui su ekspertų grupe ir darbuotojais. Šiame etape būtinas pagrindinių sąvokų apibrèžčių pateikimas bei tyrimo vykdymo ypatumų aptarimas. Kitu - trečiuoju - etapu vykdoma ekspertų bei darbuotojų apklausos ir duomenų rinkimas iš organizacijos informacinès sistemos (IS). Skaičiuojamas duomenų matricų ir ekspertų nuomonių suderinamumas, jeigu nuomonès nesuderintos, grį̌tama ị antrajji etapą, jeigu nuomonès suderintos vykdomas rezultatų interpretavimo etapas. Ketvirtuoju etapu duomenys apdorojami ir organizacija supažindinama su vertinimo rezultatais, remiantis kuriais vadovybè gali priimti darbuotojų veiklos efektyvinimo sprendimus: koreguoti ar keisti tikslus, nustatyti naujus uždavinius, susijusius su darbuotoju kvalifikacijos gerinimu, karjeros keitimu bei pačios organizacijos stiprybių užtvirtinimu ir silpnybių eliminavimu. Šių pokyčių dèka organizacijos darbuotojai atliktų darbus per trumpesni laiką, sustiprètų bendravimas ir bendradarbiavimas.

Organizacijos darbuotojo žinių vertinimui siūloma taikyti SAW, o jeigu yra galimybè arba abejojama dèl rezultatų patikimumo - ir AHP metodą. Darbuotojų žinių vertinimą siūloma atlikti pagal 4.5 lentelèje pateiktą metodiką.

Taikant SAW ir AHP metodus vykdomas ekspertinis vertinimas, todèl būtina nustatyti ekspertų nuomonių suderinamumą tokia seka: ekspertų vertinimas pertvarkomas ị rangus; apskaičiuojama kiekvieno veiksnio $x_{i}$ rangų suma visų ekspertų atžvilgiu; apskaičiuojamas visų veiksnių aritmetinis vidurkis $\bar{x}$; apskaičiuojama atitinkamo rangų sumos $x_{i}$ nuokrypio nuo aritmetinio vidurkio $\bar{x}$ kvadratų suma $S$; skaičiuojama maksimali suma $S_{\max }$; apskaičiuojamas konkordancijos koeficientas $W$ (4.3 lentelè). 


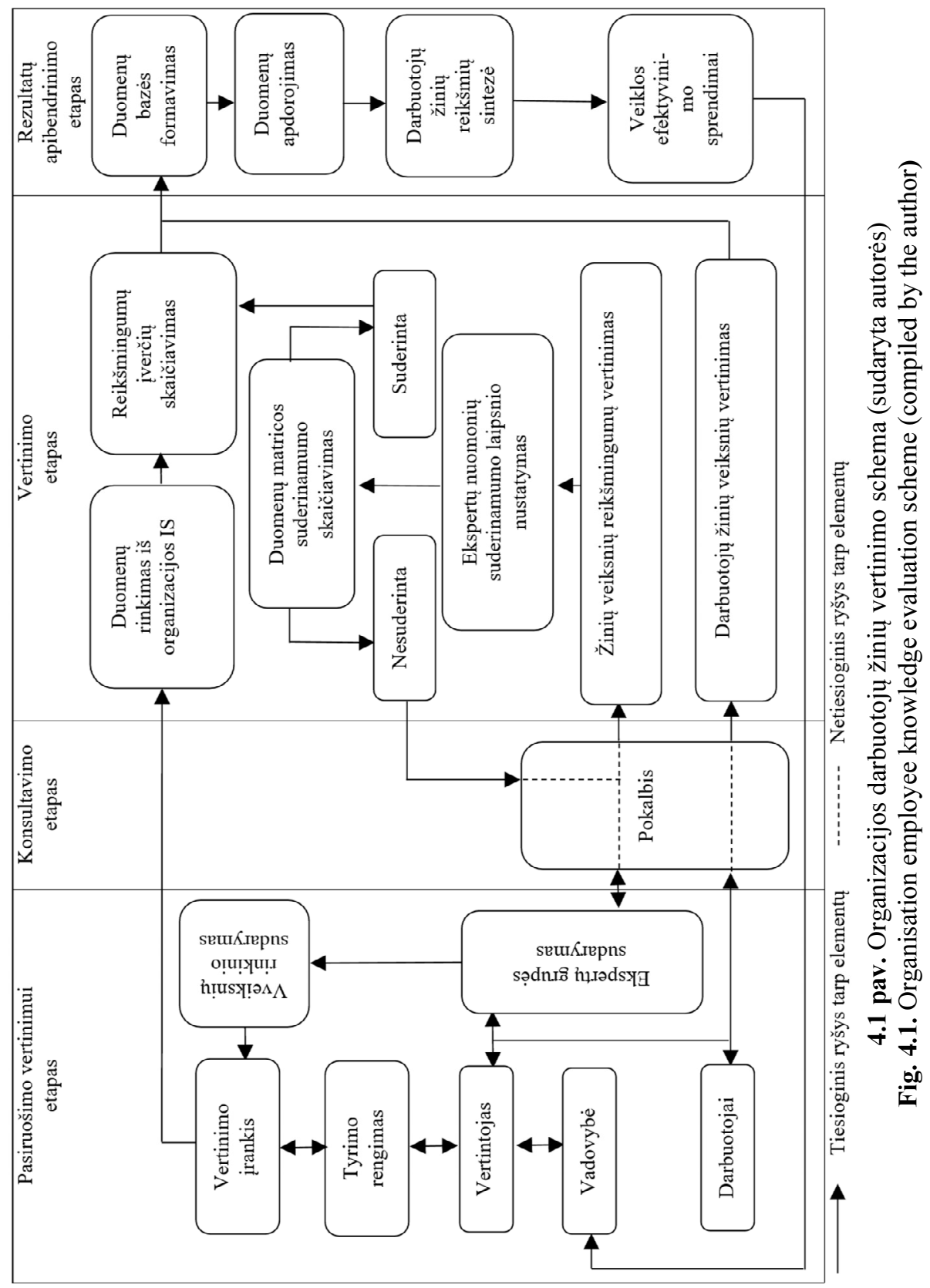


4.3 lentelè. Ekspertų nuomonių suderinamumo laipsnio nustatymas (sudaryta autorès pagal Podvezko 2008)

Table 4.3. Determination of expert opinion compatibility degree (compiled by the author based on Podvezko 2008)

\begin{tabular}{|c|c|c|}
\hline Žingsniai & Turinys & Formulès \\
\hline 1 & $\begin{array}{l}\text { Pirmas rangas suteikiamas } \\
\text { aukščiausią ivvertinimą igijusiam } \\
\text { veiksniui, antras rangas - antram } \\
\text { pagal reikšmingumą ir t. t. Vienodą } \\
\text { ìvertinimą turintiems veiksniams } \\
\text { priskirtas vienodas rangas - eilinių } \\
\text { rangu aritmetinis vidurkis. }\end{array}$ & $\begin{array}{l}r_{i}=\frac{r_{i j}+r_{i j+1}}{2}, \\
\text { čia } r_{i}-\text { rangas, } r_{i j}-\text { priskirtas } \\
\text { rangas, } r_{i j+1}-\text { sekantis rangas } \\
\text { eilèje }\end{array}$ \\
\hline 2 & $\begin{array}{l}\text { Skaičiuojama atitinkamo veiksnio } \\
x_{i} \text { rangų suma visų ekspertų } \\
\text { atžvilgiu }\end{array}$ & $\begin{array}{l}x_{i}=\sum_{j=1}^{r} x_{i j} \\
\text { čia } x_{i j} \text { - veiksnio rangas, } \mathrm{i}- \\
\text { veiksnio vieta eileje }(i=1,2, \ldots, \\
n), j \text { - eksperto vieta eileje }(j=1,2, \\
\ldots, m)\end{array}$ \\
\hline 3 & $\begin{array}{l}\text { Aritmetinis vidurkis } \bar{x} \\
\text { skaičiuojamas sudedant veiksnių } \\
\text { rangus ir dalijant iš jų skaičiaus }\end{array}$ & $\begin{array}{l}\bar{x}=\frac{\sum_{j=1}^{r} x_{i j}}{r} \\
\text { čia }(i=1, \ldots, n)\end{array}$ \\
\hline 4 & $\begin{array}{l}\text { Apskaičiuojama atitinkamo } \\
\text { veiksnio rangų sumos } x_{i} \\
\text { nuokrypio nuo aritmetinio vidurkio } \\
\bar{x} \text { kvadratu suma } \mathrm{N}\end{array}$ & $\aleph=\frac{\sum_{i=1}^{n}\left(x_{i}-\bar{x}\right)^{2}}{r}$ \\
\hline 5 & $\begin{array}{l}\text { Apskaičiuojama suma } \aleph_{\max } \\
\text { naudojant ekspertų skaičiu } p \text { ir } \\
\text { veiksnių skaičių } m\end{array}$ & $\aleph_{\max }=\frac{p^{2} m\left(m^{2}-1\right)}{12}$ \\
\hline 6 & $\begin{array}{l}\text { Skaičiuojamas konkordancijos } \\
\text { koeficientas } W \text {, tai - sumų } \aleph \text { ir } \aleph_{\max } \\
\text { santykis }\end{array}$ & $\begin{array}{l}W=\frac{\aleph}{\aleph_{\max }} \\
\text { čia } p-\text { ekspertų skaičius, } m- \\
\text { veiksnių skaičius }\end{array}$ \\
\hline
\end{tabular}

Jei apskaičiuoto konkordancijos koeficiento $W$ (4.3 lentelè 6 žingsnio formulè) reikšmè artima vienetui, tai ekspertų vertinimai neprieštaringi, t. y. suderinti. Ekspertu vertinimo suderinamumas laikomas pakankamu jei konkordancijos koeficiento $W$ reikšmé siekia 0,6 ir daugiau (4.4 lentelè). Jei vertinimai labai skiriasi, t. y. $W$ reikšmė yra arti nulio, tikslinga atlikti pakartotinę ekspertų vertinimo apklausą (Podvezko 2008). 
4.4 lentelè. Ekspertų vertinimo suderinamumo koeficiento įverčiai ir lingvistinès reikšmès (sudaryta autorès)

Table 4.4. Estimates of expert evaluation compatibility coefficient and linguistic meanings (compiled by the author)

\begin{tabular}{|l|l|l|l|l|l|}
\hline $\begin{array}{l}\text { Konkordanci- } \\
\text { jos } \\
\text { koeficiento } W \\
\text { reikšmès }\end{array}$ & $0-0,2$ & $0,2-0,4$ & $0,4-0,6$ & $0,6-0,8$ & $0,8-1$ \\
\hline $\begin{array}{l}\text { Lingvistinès } \\
\text { ekspertu } \\
\text { suderinamu- } \\
\text { mo reikšmés }\end{array}$ & Nesuderintos & $\begin{array}{l}\text { Silpnai } \\
\text { suderintos }\end{array}$ & $\begin{array}{l}\text { Vidutiniškai } \\
\text { suderintos }\end{array}$ & $\begin{array}{l}\text { Pakankamai } \\
\text { suderintos }\end{array}$ & Suderintos \\
\hline
\end{tabular}

Atliekant organizacijos darbuotojų žinių vertinimą pagal parengtą metodiką, išskiriami tokie pagrindiniai etapai: pasiruošimo vertinimui, konsultavimo, vertinimo, rezultatų apibendrinimo (4.1 pav.). Pasiruošimo etape vykdomi ekspertu grupés formavimo, veiksniu rinkinio analizès, darbuotoju žiniu veiksniu vertinimo tyrimo rengimo veiksmai. Veiksmai turi būti vykdomi nuosekliai ir jų atlikimo seka negali būti keičiama (4.5 lentelè).

4.5 lentelè. Organizacijos darbuotojų žinių vertinimo metodika (sudaryta autorès) Table 4.5. Organisation employee knowledge evaluation methods (compiled by the author)

\begin{tabular}{|c|c|c|}
\hline $\begin{array}{l}\text { Vertinimo } \\
\text { metodikos } \\
\text { etapas }\end{array}$ & Veiksmas & $\begin{array}{l}\text { Darbuotoju žinių vertinimo metodikos } \\
\text { taikymo seka }\end{array}$ \\
\hline \multirow[t]{2}{*}{$\begin{array}{l}\text { 1. Pasiruoši- } \\
\text { mo vertinimui }\end{array}$} & $\begin{array}{l}\text { 1.1. Ekspertu } \\
\text { grupès } \\
\text { formavimas }\end{array}$ & $\begin{array}{l}\text { 1.1.1. Pokalbio su vadovybe vykdymas; } \\
\text { 1.1.2. Ekspertu grupés formavimas, kriteriju } \\
\text { ekspertu atrankai parinkimas arba siūlomi tokie } \\
\text { ekspertų atrankos kriterijai: užimamos pareigos } \\
\text { (vadovas, vadovo pavaduotojas, skyriaus ar } \\
\text { filialo vadovas); dalyvavimo vertinimo grupèse } \\
\text { skaičius (pvz., audito, projektinès grupès); } \\
\text { darbo patirtis (ne mažesnè kaip } 3 \text { metai } \\
\text { tiriamoje srityje); } \\
\text { 1.1.3. Ekspertu grupès patvirtinimas; }\end{array}$ \\
\hline & $\begin{array}{l}\text { 1.2. Veiksnių } \\
\text { rinkinio } \\
\text { patvirtinimas/ } \\
\text { analizè/ } \\
\text { sudarymas }\end{array}$ & $\begin{array}{l}\text { 1.2.1. Išreikštinių žiniu bloko kiekybinių - } \\
\text { profesine patirtis, darbuotojo darbo } \\
\text { užmokestis, kvalifikacijos tobulinimas - } \\
\text { veiksniu rinkinio aptarimas (jeigu yra poreikis } \\
\text { keisti veiksnius, pokalbio metu juos parenka } \\
\text { vadovas/ekspertu grupè); }\end{array}$ \\
\hline
\end{tabular}


4.5 lentelès tęsinys

\begin{tabular}{|c|c|c|}
\hline $\begin{array}{l}\text { Vertinimo } \\
\text { metodikos } \\
\text { etapas }\end{array}$ & Veiksmas & $\begin{array}{l}\text { Darbuotojų žinių vertinimo metodikos } \\
\text { taikymo seka }\end{array}$ \\
\hline & & $\begin{array}{l}\text { 1.2.2. Išreikštinių žiniu bloko kokybinių - } \\
\text { išsilavinimas, technologiju naudojimas darbe, } \\
\text { pareigų lygis - veiksniu rinkinio aptarimas } \\
\text { (jeigu yra poreikis keisti veiksnius, pokalbio } \\
\text { metu juos parenka vadovas/ekspertu grupé); } \\
\text { 1.2.3. Neišreikštiniu žinių bloko kokybinių - } \\
\text { darbo sudettingumas, darbuotojo itaka } \\
\text { organizacijos tikslu igyvendinimui, darbo } \\
\text { kultūra, atsakomybè, motyvacija dirbti, } \\
\text { savarankiškumas darbe - veiksniu rinkinio } \\
\text { aptarimas (jeigu yra poreikis keisti veiksnius } \\
\text { pokalbio metu parenka vadovas/ekspertu } \\
\text { grupė); } \\
\text { 1.2.4. Vertinimo skalès parinkimas pagal } 4 \\
\text { lentelès skaliu pateiktis }\end{array}$ \\
\hline & $\begin{array}{l}\text { 1.3. Darbuotojų } \\
\text { žinių veiksnių } \\
\text { vertinimo tyrimo } \\
\text { rengimas }\end{array}$ & $\begin{array}{l}\text { 1.3.1. Apklausos tipo parinkimas; } \\
\text { 1.3.2. Tyrimo instrumento parengimas; } \\
\text { 1.3.3. Anketų pildymo instrukcijų parengimas }\end{array}$ \\
\hline $\begin{array}{l}\text { 2. Konsulta- } \\
\text { vimo }\end{array}$ & $\begin{array}{l}\text { 2.1. Pokalbių } \\
\text { organizavimas }\end{array}$ & $\begin{array}{l}\text { 2.1.1. Pokalbio su darbuotojais vykdymas; } \\
\text { 2.1.2. Pokalbio su ekspertu grupe vykdymas }\end{array}$ \\
\hline \multirow[t]{2}{*}{ 3. Vertinimo } & $\begin{array}{l}\text { 3.1. Darbuotojų } \\
\text { žinių veiksnių } \\
\text { vertinimas }\end{array}$ & $\begin{array}{l}\text { 3.1.1. Ekspertụ grupės apklausos vykdymas: } \\
\text { 3.1.1.1. Darbuotojo žinias formuojančių } \\
\text { pagrindinių veiksnių reikšmingumų vertinimas } \\
\text { rangavimo būdu; } \\
\text { 3.1.1.2. Darbuotojo žinias formuojančių } \\
\text { pagrindinių veiksnių reikšmingumų vertinimas } \\
\text { porinio lyginimo būdu; } \\
\text { 3.1.2. Darbuotojų apklausos vykdymas; } \\
\text { 3.1.3. Išreikštinių žinių bloko kiekybinių } \\
\text { veiksnių dedamujų reikšmių iš organizacijos } \\
\text { informacinès sistemos rinkimas }\end{array}$ \\
\hline & $\begin{array}{l}\text { 3.2. Ekspertu } \\
\text { nuomonių } \\
\text { suderinamumo } \\
\text { laipsnio } \\
\text { nustatymas }\end{array}$ & $\begin{array}{l}\text { 3.2.1. Ekspertu nuomonių suderinamumo } \\
\text { laipsnio, naudojant } 4.3 \text {. lentelëje aprašytus } \\
\text { žingsnius, skaičiavimas }\end{array}$ \\
\hline
\end{tabular}


4.5 lentelès pabaiga

\begin{tabular}{|c|c|c|}
\hline $\begin{array}{l}\text { Vertinimo } \\
\text { metodikos }\end{array}$ & Veiksmas & $\begin{array}{c}\text { Darbuotojų žinių vertinimo metodikos } \\
\text { taikymo seka }\end{array}$ \\
\hline & $\begin{array}{l}\text { 3.3. Ekspertų } \\
\text { reikšmingumų } \\
\text { iverčiu } \\
\text { skaičiavimas }\end{array}$ & $\begin{array}{ll}\text { 3.3.1. Išreikštinių } & (\alpha) \text { ir neišreikštiniu }(\beta) \\
\text { žiniu bloko reikšmingumo iverčiu } \\
\text { skaičiavimas; }\end{array}$ \\
\hline \multirow[t]{2}{*}{$\begin{array}{l}\text { 4. Rezultatu } \\
\text { apibendrini- } \\
\text { mo }\end{array}$} & $\begin{array}{l}\text { 4.1. Duomenu } \\
\text { apdorojimas }\end{array}$ & $\begin{array}{l}\text { 4.1.1. Darbuotojų išreikštiniu žiniu } \\
\text { kiekybinių veiksnių } \\
\text { normalizavimas; } \\
\text { 4.1.2. Darbuotoju išreikštinių žinių kokybinių } \\
\text { veiksnių dedamujų normalizavimas; } \\
\text { 4.1.3. Darbuotoju neišreikštiniu žiniu } \\
\text { veiksnių dedamujų normalizavimas }\end{array}$ \\
\hline & $\begin{array}{l}\text { 4.2. Darbuotojų } \\
\text { žinių reikšmių } \\
\text { sintezé }\end{array}$ & $\begin{array}{l}\text { 4.2.1. Darbuotoju išreikštinių žinių bloko } \\
\text { iverčių skaičiavimas; } \\
\text { 4.2.2. Darbuotojų neišreikštiniu žinių bloko } \\
\text { iverčių skaičiavimas; } \\
\text { 4.2.3. Visų žinių veiksnių dedamuju } \\
\text { apjungimas (integravimas) i apibendrintaji } \\
\text { ivverti }\end{array}$ \\
\hline
\end{tabular}

Eksperty grupes formavimas pradedamas nuo reikalavimų nustatymo ekspertu atrankos kriterijams ir būdams, pokalbio su vadovybe, kurio metu aptariamas tyrimo vykdymo laikas ir ekspertu kompetencijos bei ekspertu skaičius. Ekspertų atrankos kriterijai gali būti ịvairūs, priklausomai nuo to, kokioje srityje dirba organizacija. Iprastai ekspertai renkami remiantis jų charakteristikomis, susijusiomis su profesine kompetencija: darbo patirtimi, stažu, moksliniu laipsniu ir moksline veikla, gebejjimu spręsti konkrečias atitinkamos srities problemas (Hora 2009). Ekspertų kompetencijos nustatymui tikslinga taikyti vieną ar kelis pasirinktus - dokumentini, eksperimentinį, balsavimo, savęs vertinimo - būdus (4.6 lentelè).

Sudaroma ekspertu grupe, pagal metodikos 1.1.3 punkte nurodytus arba pasirinktus organizacijos vadovybès kriterijus. Ekspertų grupès skaičių organizacijos darbuotoju žinioms vertinimo užduočiai atlikti nustato vadovybė kartu su vertintoju pokalbio metu. Rekomenduojamas ekspertu grupès narių skaičius ne mažesnis nei trys, kad būtų didesnis nuomonių pasiskirstymas, ir ne didesnis nei 10, kad gauti rezultatai būtų patikimi ir objektyvūs (Podvezko 2008). A. Augustinaitis et al. (2009) teigia, jog optimalus ekspertu grupès dydis yra nuo 
8 iki 10 nariu (4.2 pav.) ir rekomenduoja apklausti ne mažiau nei 5 ekspertus. Didejjant ekspertu skaičiui nuo 9 vertinimo patikimumas didejja nežymiai, todèl tikslinga formuoti ekspertų grupę iš 5-9 narių.

4.6 lentelè. Ekspertų kompetencijos nustatymo būdai (sudaryta autorès pagal Tidiki 2003)

Table 4.6. Ways of expert competency determination (compiled by the author based on Tidikis 2003)

\begin{tabular}{|l|l|}
\hline \multicolumn{1}{|c|}{ Būdai } & \multicolumn{1}{c|}{ Aprašymo turinys } \\
\hline Dokumentinis & $\begin{array}{l}\text { Nustatomos kompetencijos vertinant socialinius - demografinius } \\
\text { eksperto duomenis }\end{array}$ \\
\hline Eksperimentinis & $\begin{array}{l}\text { Kompetencijos vertinimas testavimo, ankstesnès ekspertu veiklos } \\
\text { efektyvumo patikrinimo pagrindu. Ekspertams užduodami paprasti } \\
\text { tekstiniai klausimai, kurių rezultatas turi sutapti su tikrais } \\
\text { rezultatais. Šis būdas naudojamas retai dèl klausimų sistemos } \\
\text { kūrimo sunkumo bei ekspertiniu uždavinių vertinimo subjektyvumo }\end{array}$ \\
\hline Balsavimas & $\begin{array}{l}\text { Kompetencijos vertinimas atestavimo būdu, kai asmenis } \\
\text { rekomenduoja grupe }\end{array}$ \\
\hline $\begin{array}{l}\text { Savęs } \\
\text { vertinimas }\end{array}$ & Kompetencijos vertinimas vykdomas atliekant savianalizę \\
\hline
\end{tabular}

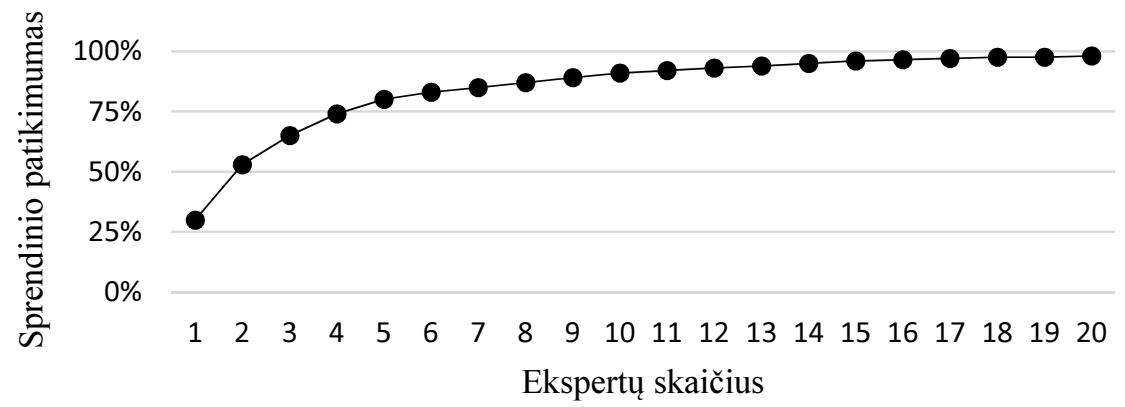

4.2 pav. Ekspertų skaičiaus ịtaka vertinimo patikimumui (Augustinaitis et al. 2009)

Fig. 4.2. Impact of the number of experts on evaluation reliability (Augustinaitis et al. 2009)

Po ekspertu grupès suformavimo vykdoma pagrindinių pateiktų darbuotojo žinias formuojančių veiksniu rinkinio analizè (aptarimas). Vadovybẻ bei ekspertai išanalizuoja ir susipažista su išreikštinių žinių bloko kiekybinių ir kokybinių bei 
neišreikštinių žinių bloko kokybinių žinių veiksnių turiniu bei dedamosiomis, o esant poreikiui juos gali keisti kitu veiksniu. Tokiu atveju, būtina nustatyti keičiamo veiksnio dedamąsias, o vykdant ekspertinę ir darbuotojų apklausą būtinas naujo veiksnio įtraukimas i apklausą. Pokalbio metu, vertintojas, vadovybè ir/arba ekspertų grupé aptaria anketos vertinimo skales, jų tipus (4.7 lentelè).

4.7 lentelè. Skalių ịverčiai ir reikšmės (sudaryta autorės pagal Stevens 1946)

Table 4.7. Scale estimates and meanings (compiled by the author based on Stevens 1946)

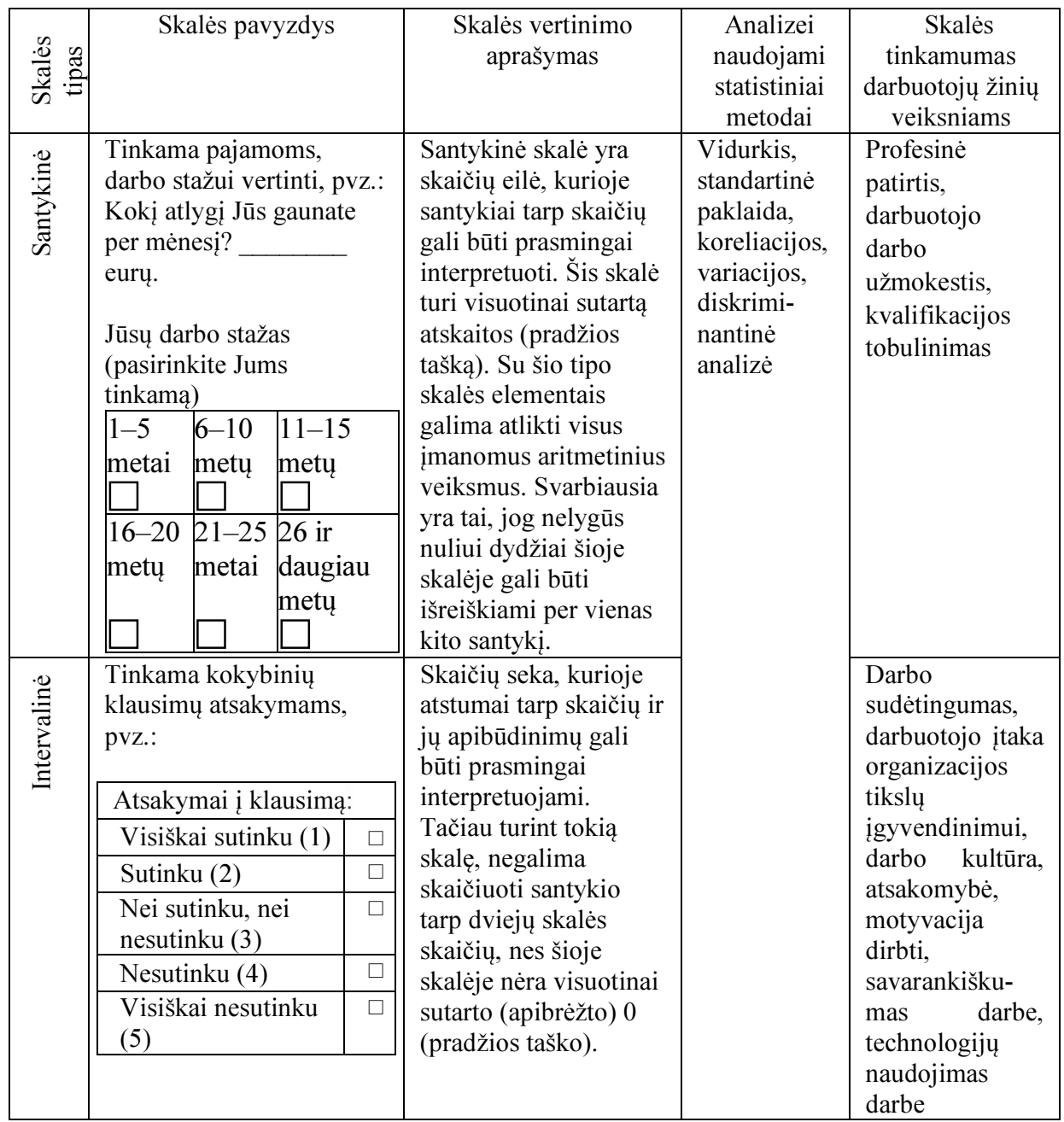


4.7 lentelès pabaiga

\begin{tabular}{|c|c|c|c|c|}
\hline 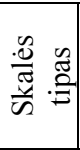 & Skalės pavyzdys & $\begin{array}{c}\text { Skalès vertinimo } \\
\text { aprašymas }\end{array}$ & $\begin{array}{l}\text { Analizei } \\
\text { naudojami } \\
\text { statistiniai } \\
\text { metodai }\end{array}$ & $\begin{array}{c}\text { Skalès } \\
\text { tinkamumas } \\
\text { darbuotojų žinių } \\
\text { veiksniams }\end{array}$ \\
\hline 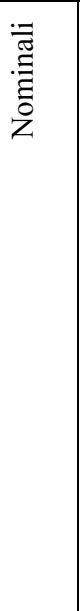 & $\begin{array}{l}\text { Naudojama kai turime } \\
\text { plataus pasirinkimo } \\
\text { klausimus, pvz.: } \\
\text { Jūsu lytis? } \\
\text { 1. Vyras } \\
\text { 2. Moteris }\end{array}$ & $\begin{array}{l}\text { Nominalinė skalè - } \\
\text { skaičiu eilè, kurioje } \\
\text { skaičiai atlieka } \\
\text { identifikavimo } \\
\text { funkciją, t. y. skaičiai } \\
\text { tik pažymi tam tikrą } \\
\text { objektą. Paprastai } \\
\text { tokia skalè naudojama } \\
\text { „arba-arba“ tipo } \\
\text { klausimams. Atliekant } \\
\text { nominalinès skalès } \\
\text { duomenų analizę } \\
\text { skaičiuojama } \\
\text { pasirinktų atsakymų } \\
\text { dažnumus ir tų } \\
\text { dažnumu procentinis } \\
\text { pasiskirstymas. }\end{array}$ & $\begin{array}{l}\text { Dažnis, } \\
\text { procentas, } \\
\text { moda, Ksi - } \\
\text { kvadrato } \\
\text { testas } \chi^{2}\end{array}$ & Išsilavinimas \\
\hline 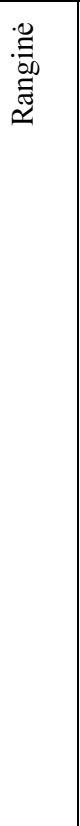 & $\begin{array}{l}\text { Tinkama surikiuoti ị eilę } \\
\text { rodiklius, veiksnius, } \\
\text { dedamąsias, pvz.: } \\
1 \text { - nagrinejjamam } \\
\text { reiškiniui didžiausią įtaką } \\
\text { darantis arba svarbiausias } \\
\text { rodiklis (veiksnys, } \\
\text { dedamoji); } \\
2 \text { - nagrinėjamam } \\
\text { reiškiniui vidutinę ittaką } \\
\text { darantis arba vidutiniškai } \\
\text { svarbus rodiklis } \\
\text { (veiksnys, dedamoji); } \\
3 \text { - nagrinėjamam } \\
\text { reiškiniui mažiausią įtaką } \\
\text { darantis arba mažiausiai } \\
\text { svarbus rodiklis } \\
\text { (veiksnys, dedamoji) }\end{array}$ & $\begin{array}{l}\text { Svarbesniam rodikliui } \\
\text { (veiksniui, dedamajai) } \\
\text { suteikiama aukštesnis } \\
\text { ivertinimas, t. y. } \\
\text { aukščiausią ìvertinimą } \\
\text { igijusiam rodikliui } \\
\text { (veiksniui, dedamajai) } \\
\text { suteiktas } 1 \text { rangas, } \\
\text { antram pagal } \\
\text { reikšmingumą-2 } \\
\text { rangas ir t. t. Vienodą } \\
\text { ivertinimą turintiems } \\
\text { rodikliams } \\
\text { priskiriamas vienodas } \\
\text { rangas - eilinių rangu } \\
\text { aritmetinis vidurkis. } \\
\text { Galimas atvirkštinis } \\
\text { rangavimas, t. y. kai } \\
\text { didesni skaičių } \\
\text { atitinka didesne ar } \\
\text { svarbesnè rodiklio } \\
\text { (veiksnio, } \\
\text { dedamosios) reikšmé }\end{array}$ & $\begin{array}{l}\text { Mediana, } \\
\text { moda, } \\
\text { reikšmin- } \\
\text { gumo testas }\end{array}$ & $\begin{array}{l}\text { Darbo sudètin- } \\
\text { gumas, pareigu } \\
\text { lygis }\end{array}$ \\
\hline
\end{tabular}

Darbuotojų žinių veiksnių vertinimo tyrimo rengimo metu skaičiuojama tyrimo imtis, parenkamas apklausos tipas, rengiamas tyrimo instrumentas - 
anketa, ir ruošiama jų pildymo instrukcija. Konsultavimo metu vykdomas pokalbiu organizavimas, darbuotojams ir ekspertams pravedamas instruktažas apie anketų pildymą.

Vertinimo etape vykdomi du veiksmai: darbuotojų žiniu veiksniu vertinimas ir eksperty nuomoniu suderinamumo laipsnio skaičiavimas, jų metu atliekama formalizuota darbuotojų ir ekspertų apklausa. Darbuotojams pateikiamos anketos surinkti duomenis apie darbuotojo turimas ir darbe taikomas žinias. Ekspertams pateikiamos atitinkamos vertintojo sudarytos skirtingos, pritaikytos SAW ir AHP metodams, anketos. Ekspertai vertina darbuotojo išreikštinių ir neišreikštinių žinių blokus, jų veiksnius ir dedamąsias.

Rezultatu apibendrinimo metu atliekama ekspertu reikšmingumu ìverčiu skaičiavimas, duomeny apdorojimas, darbuotoju žiniu reikšmiu sintezè. Vertintojas apibendrina gautus duomenis, t. y. apskaičiuoja ekspertų ịvertintus veiksnių reikšmingumus, žinių blokų ịverčius ir gautas reikšmes integruoja ị apibendrintaji ịvertị, gautus rezultatus vizualizuoja ir pristato organizacijos vadovybei bei darbuotojams.

\subsubsection{Organizacijos darbuotojų žinių vertinimo tyrimo rezultatai}

Siekiant patikrinti sukurtos organizacijos darbuotojų žinių vertinimo metodikos praktini pritaikomumą atliktas empirinis tyrimas taikant daugiakriterinius - SAW ir AHP - metodus. Tyrimas atliktas $2017 \mathrm{~m}$. balandžio mèn. Tyrimui atlikti organizacijos atrinktos pagal tris kriterijus: organizacijos gyvavimo versle trukmé (ne trumpesnè nei 5 metų), darbuotojų skaičius (įmonè priklausytų bent vienam iš triju - vidutinès, mažos ir labai mažos - įmonių tipui) bei finansinius duomenis (imonès metinès pajamos ne mažesnès nei $2 \mathrm{mln}$. eurų). Didelès organizacijos iprastai skaidomos ị padalinius, todèl darbuotojų žinių vertinimą tikslinga atlikti padaliniuose. Padalinių darbuotojų skaičius iprastai neviršija vidutinès organizacijos narių skaičiaus. Atsižvelgiant i tai bei susidūrus su tokių organizaciju informacijos prieinamumo problema šiame darbe nuspręsta atsisakyti didelių organizacijų kaip tyrimo objekto.

Tyrimo vykdymui, atsižvelgiant i numatytus kriterijus, pasirinktos penkios verslo organizacijos, iš kurių dvi veiklą vykdo Lietuvoje, viena - Australijoje, dvi - Airijoje (4.8 lentelè). Iš jų po vieną Lietuvoje ir Airijoje atitinka vidutinių imonių reikalavimus, t. y. tai įmonès, kuriose dirba mažiau kaip 250 darbuotojų ir kurių finansiniai duomenys atitinka bent vieną iš šių sąlygų: įmonès metinès pajamos neviršija $50 \mathrm{mln}$. eurų; i̇monès balanse nurodyto turto vertè neviršija $43 \mathrm{mln}$. eurų. Viena įmonè ịsikūrusi Australijoje ir viena Lietuvoje atitinka mažos imonès reikalavimus, t. y. tai įmonès, kuriose dirba mažiau kaip 50 darbuotojų ir kurių finansiniai duomenys atitinka bent vieną iš šių sąlygų: imonès metinès 
pajamos neviršija $10 \mathrm{mln}$. eurų; įmonès balanse nurodyto turto vertè neviršija $10 \mathrm{mln}$. Eurų. Viena įmonè Airijoje atitinka labai mažos ịmonès reikalavimus, t. y. tai įmonè, kurioje dirba mažiau kaip 10 darbuotojų ir kurios finansiniai duomenys atitinka bent vieną iš šių sąlygų: įmonès metinès pajamos neviršija 2 mln. eurų; imonès balanse nurodyto turto vertè neviršija $2 \mathrm{mln}$. eurų.

4.8 lentelè. Organizacijų, kuriose atliktas tyrimas, charakteristika (sudaryta autorès)

Table 4.8. Characteristics of researched organisations (compiled by the author)

\begin{tabular}{|c|c|c|}
\hline $\begin{array}{l}\text { Pavadinimas, } \\
\text { vadovas, } \\
\text { ikūrimo metai }\end{array}$ & $\begin{array}{l}\text { Darbuotojuc } \\
\text { skaičius }\end{array}$ & Trumpas aprašymas \\
\hline $\begin{array}{l}\text { VI „X miškų } \\
\text { uredija“" } \\
\text { Miškų urèdas } \\
1957\end{array}$ & 84 & $\begin{array}{l}\text { Vykdoma kompleksine mišku ūkio veikla } \\
\text { valstybiniuose miškuose, Aplinkos ministerijos } \\
\text { nustatyta tvarka vykdomi privalomieji miško } \\
\text { atkūrimo, apsaugos ir tvarkymo darbai, parduodama } \\
\text { pagaminta apvalioji mediena bei nenukirstas } \\
\text { miškas, vykdoma kita veikla, numatyta mišku } \\
\text { uredijos ịstatuose. }\end{array}$ \\
\hline $\begin{array}{l}\text { UAB „Skrema“ } \\
\text { Dalius } \\
\text { Skrebūnas } \\
1998\end{array}$ & 11 & $\begin{array}{l}\text { Gaminama penkių tipų produkcija - langai, durys, } \\
\text { žaliuzės, garažu vartai ir užtvarai bei jiems } \\
\text { priklausanti automatika - taip pat teikiamos } \\
\text { montavimo ir priežiūros paslaugos. Vis dèlto } \\
\text { pagrindinė įmonés veikla - plastikinių langu ir durų } \\
\text { gamyba, kreipiant dideli demesi gaminiu kokybei. } \\
\text { Visa informacija imone pateikia internetiniame } \\
\text { tinklapyje: http://www.skrema.lt/. }\end{array}$ \\
\hline $\begin{array}{l}\text { „Geelong } \\
\text { Garage Doors“ } \\
\text { Rob Serra } \\
1998\end{array}$ & 17 & $\begin{array}{l}\text { Gaminama ivairiu tipu garažu vartai ir jiems } \\
\text { priklausanti automatika - taip pat teikiamos } \\
\text { montavimo ir priežiūros paslaugos. Imonè } \\
\text { specializuojasi automatikos programavimu, t. y. } \\
\text { programuoja pultelius ir diegia specializuotą } \\
\text { programą ị mobiliuosius telefonus. Informaciją apie } \\
\text { imonę ir jos darbo pobūdi galima rasti tinklapyje: } \\
\text { http://geelonggaragedoors.com.au/. }\end{array}$ \\
\hline $\begin{array}{l}\text { „Kiverco“ } \\
\text { Aidan ir Anne } \\
\text { McKiver } \\
1993\end{array}$ & 97 & $\begin{array}{l}\text { Perdirbimo ir atlieku rūšiavimo įmonè turinti didelę } \\
\text { patirtị projektuojant ir montuojant rūšiavimo linijas, } \\
\text { teikianti panašios paskirties gamyklų priežiūros } \\
\text { paslaugas. Informaciją apie imonę ir jos darbo } \\
\text { pobūdi galima rasti tinklapyje: } \\
\text { http://www.kiverco.com. }\end{array}$ \\
\hline
\end{tabular}


4.8 lentelès pabaiga

\begin{tabular}{|l|l|l|}
\hline $\begin{array}{c}\text { Pavadinimas, } \\
\text { vadovas, } \\
\text { ikūrimo metai }\end{array}$ & $\begin{array}{c}\text { Darbuotojų } \\
\text { skaičius }\end{array}$ & \multicolumn{1}{c|}{ Trumpas aprašymas } \\
\hline $\begin{array}{l}\text { „Flowerbox“ } \\
\text { Kerry Lamb, } \\
2011\end{array}$ & 7 & $\begin{array}{l}\text { İmone prekiauja ịvairiomis gèlemis ir papuošimais, } \\
\text { siunčia puokštes, dovanas paštu, užsiima saliù } \\
\text { puošimu įvairiomis progomis. Informaciją apie šios }\end{array}$ \\
\hline & & $\begin{array}{l}\text { imonès veiklą ir teikiamas paslaugas galima rasti } \\
\text { internetiniame tinklapyje: } \\
\text { http://www.flowerboxni.com/default.aspx. }\end{array}$ \\
\hline
\end{tabular}

Ekspertu grupès formavimas. Ekspertu atrankai taikyti trys kriterijai: ne mažiau kaip 5 metai vadovaujamo darbo patirtis, dalyvavimas ne mažiau nei dvejuose projektuose ar darbo grupèse ir ne mažiau kaip 10 metų darbo patirtis verslo srityje. Tokiu būdu atrinkti 9 ekspertai iš skirtingu verslo i̇monių, 2 ekspertai iš Australijos, 1 ekspertas iš Airijos, 1 ekspertas iš Vokietijos, 5 ekspertai iš Lietuvos. Vidutine ekspertu vadovavimo patirtis $-10,4$ metų, o vidutinis darbo stažas - 16,5 metų. Kiekvienas ekspertas vidutiniškai yra dalyvavęs 3-uose projektuose arba darbo grupèse.

Darbuotojų žinias formuojančiu pagrindinių veiksniu rinkinys sudarytas remiantis 3.1 skyriuje atliktu tyrimu, t. y. veiksniai parinkti ir sugrupuoti i du išreikštinių ir neišreikštinių - žinių blokus pagal jų tipą ir vertinimo pobūdį kiekybiniai ir kokybiniai. Veiksniai pateikti 4.5 lenteleje 1.2.1, 1.2.2 ir 1.2.3 punktuose.

Tyrimo rengimas. Ekspertams ir darbuotojams parengtos skirtingos apklausos anketos pritaikytos vertinti veiksnius dviem - SAW ir AHP - metodais. Parengtos instrukcijos, kuriose nurodyta ekspertų užduotis, pagrindinių sąvokų apibrèžtys bei pildymo tvarka.

Pokalbiu organizavimas. Atsižvelgiant i anketų skirtumus, pokalbiai su ekspertų grupe ir darbuotojais organizuoti atskirai. Konsultavimo metu paaiškinta veiksnių ir dedamujų turinys, pateikta anketu pildymo instrukcija bei atsakyta $\mathfrak{i}$ klausimus.

Darbuotoju žiniu veiksniu vertinimas (SAW metodu). Ekspertų apklausa vykdyta anketinès apklausos būdu (F priedas). Ekspertams buvo parengta ir pateikta apklausos anketa atsižvelgiant i SAW metodo ypatumus. Pridètoje instrukcijoje buvo nurodyta ekspertu užduotis - ivertinti kiekvieno anketoje irašyto žinių bloko ir jų veiksnių reikšmingumus. Apdorojus anketų rezultatus ekspertų galutiniai reikšmingumai pasiskirste taip: 0,41 - išreikštinių žinių blokui ir 0,59 - neišreikštinių žinių blokui. Išreikštinių žinių bloke didžiausią reikšmingumą igijo „Profesinès patirties“ veiksnys $(0,28)$, o neišreikštinių žinių bloko - „Motyvacija dirbti““( 0,22$)$ (4.9 lentelè). 
4.9 lentelè. Žinių blokų veiksnių įverčiai (sudaryta autorès)

Table 4.9. Estimates of knowledge block factors (compiled by the author)

\begin{tabular}{|c|c|c|c|c|c|c|c|c|c|c|c|}
\hline Ekspertai & E1A & E2A & E3A & E4V & E5L & E6L & E7L & E8L & E9L & 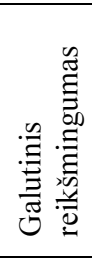 & 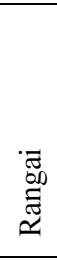 \\
\hline \multicolumn{11}{|c|}{ Išreikštinių žinių bloko veiksniai } & \\
\hline$I_{l}$ & 0,15 & 0,1 & 0,2 & 0,15 & 0,2 & 0,45 & 0,3 & 0,1 & 0,35 & 0,22 & 2 \\
\hline$I_{2}$ & 0,15 & 0,3 & 0,2 & 0,3 & 0,3 & 0,15 & 0 & 0,2 & 0,2 & 0,20 & 3 \\
\hline$I_{3}$ & 0,25 & 0,3 & 0,3 & 0,25 & 0,3 & 0,2 & 0,5 & 0,15 & 0,3 & 0,28 & 1 \\
\hline$I_{4}$ & 0,1 & 0,1 & 0,1 & 0,05 & 0,05 & 0,05 & 0 & 0,1 & 0,02 & 0,06 & 6 \\
\hline$I_{5}$ & 0,2 & 0,1 & 0,15 & 0,05 & 0,05 & 0,05 & 0,2 & 0,2 & 0,03 & 0,11 & 5 \\
\hline$I_{6}$ & 0,15 & 0,1 & 0,05 & 0,2 & 0,1 & 0,1 & 0 & 0,25 & 0,1 & 0,12 & 4 \\
\hline \multicolumn{11}{|c|}{ Neišreikštinių žinių bloko veiksniai } & \\
\hline$N_{l}$ & 0,1 & 0,1 & 0,1 & 0 & 0,1 & 0 & 0,1 & 0 & 0 & 0,06 & 6 \\
\hline$N_{2}$ & 0,2 & 0,15 & 0,15 & 0,5 & 0,15 & 0,5 & 0,2 & 0 & 0 & 0,21 & 2 \\
\hline$N_{3}$ & 0,2 & 0,25 & 0,1 & 0 & 0,1 & 0 & 0,1 & 0,1 & 0,3 & 0,13 & 5 \\
\hline$N_{4}$ & 0,2 & 0,2 & 0,25 & 0 & 0,2 & 0,3 & 0,2 & 0,2 & 0,2 & 0,19 & 4 \\
\hline$N_{5}$ & 0,1 & 0,25 & 0,2 & 0,05 & 0,25 & 0 & 0,2 & 0,4 & 0,5 & 0,22 & 1 \\
\hline$N_{6}$ & 0,2 & 0,05 & 0,2 & 0,45 & 0,2 & 0,2 & 0,2 & 0,3 & 0 & 0,20 & 3 \\
\hline
\end{tabular}

Čia išsilavinimas $-I_{1}$, technologijų naudojimas darbe $-I_{2}$, profesine patirtis $-I_{3}$, pareigu lygis $-I_{4}$, darbuotojo darbo užmokestis $-I_{5}$, kvalifikacijos tobulinimas $-I_{6}$, darbo sudètingumas $-N_{l}$, darbuotojo įtaka organizacijos tikslų igyvendinimui $-N_{2}$, darbo kultūra $-N_{3}$, atsakomybe $-N_{4}$, motyvacija dirbti $-N_{5}$, savarankiškumas darbe $-N_{6}$, E1A, E2A - ekspertai iš Australijos, E3A - ekspertas iš Airijos, E4V - ekspertas iš Vokietijos, E5L, E6L, E7L, E8L, E9L - ekspertai iš Lietuvos.

Ekspertai veiksnius rangavo atsižvelgdami ị to veiksnio svarbą darbuotojo žinioms, aukščiausias rangas suteikiamas mažiausiai rangu sumos reikšmei. Rangų suma ir galutinio rango išreikštinių žinių bloke pasiskirstymas pateiktas 4.10 lenteleje.

Ranguojant ir vertinant veiksnių reikšmingumus išreikštinių žinių bloke sutapo keleto veiksnių ịverčiai: veiksniui „Profesinè patirtis“ suteikta pirmoji vieta, penktoji ir šeštoji vietos atitinkamai suteiktos veiksniams „Pareigų lygis“, „Darbuotojo darbo užmokestis“. Neišreikštinių žinių bloke tiek ranguojant, tiek ir vertinant veiksnių „Motyvacija dirbti“, „Savarankiškumas darbe“, „Darbo kultūra“, „Darbo sudètingumas“ reikšmingumus, vietos nesikeičia, t. y. sutampa pirmoji, trečioji, penktoji bei šeštoji vietos (4.3 pav.). 
4.10 lentelè. Ekspertų veiksnių rangų pasiskirstymas (sudaryta autorès)

Table 4.10. Distribution of expert factor ranks (compiled by the author)

\begin{tabular}{|l|l|l|l|l|l|l|}
\hline \multicolumn{7}{|c|}{ Išreikštinių žinių bloko veiksniai } \\
\hline & $I_{1}$ & $I_{2}$ & $I_{3}$ & $I_{4}$ & $I_{5}$ & $I_{6}$ \\
\hline Rangų suma & 33 & 20 & 20 & 47 & 39,5 & 29,5 \\
\hline Galutinis rangas & 4 & 1,5 & 1,5 & 6 & 5 & 3 \\
\hline \multicolumn{7}{|c|}{ Neišreikštinių žinių bloko veiksniai } \\
\hline & $N_{1}$ & $N_{2}$ & $N_{3}$ & $N_{4}$ & $N_{5}$ & $N_{6}$ \\
\hline Rangų suma & 46 & 42 & 44 & 32 & 27 & 36 \\
\hline Galutinis rangas & 6 & 4 & 5 & 2 & 1 & 3 \\
\hline
\end{tabular}

Ekspertu anketine apklausa (AHP metodu). Ekspertams buvo parengta ir pateikta apklausos anketa atsižvelgiant i AHP metodo ypatumus ( $\mathrm{G}$ priedas). Kiekvienam ekspertui buvo pateiktos sudarytos atskiros žinių blokų veiksnių lentelès (išreikštinių žinių bloko veiksnių lentelès pavyzdys pateiktas 4.11 lentelëje) ir lentelių pildymo instrukcijos, veiksnių apibrežtys bei vertinimo skalè. Pridètoje instrukcijoje buvo nurodyta ekspertų užduotis (poromis palyginti veiksnius bei jų dedamąsias), pateikti teiginių lyginimo pavyzdžiai. Iškilus neaiškumams ekspertai buvo konsultuojami naudojant internetines bei mobilias pokalbių programas.

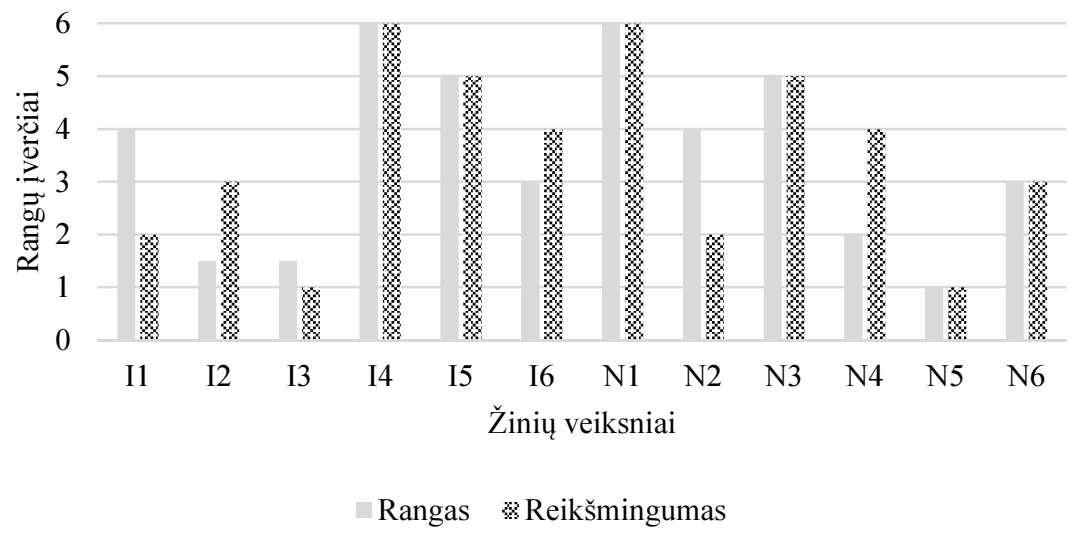

4.3 pav. Veiksnių galutiniai rangai (sudaryta autorès)

Fig. 4.3. Final factor ranks (compiled by the author) 
4.11 lentelè. Eksperto užpildyta lentelè AHP porinio lyginimo būdu (sudaryta autorès) Table 4.11. Table filled in by an expert by way of AHP pairwise comparison (compiled by the author)

\begin{tabular}{|c|c|c|c|c|c|c|c|}
\hline \multirow{8}{*}{ 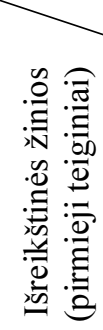 } & \multicolumn{7}{|c|}{ Išreikštinès žinios (antrieji teiginiai) } \\
\hline & Veiksniai & $I_{1}$ & $I_{2}$ & $I_{3}$ & $I_{4}$ & $I_{5}$ & $I_{6}$ \\
\hline & $I_{1}$ & 1 & 5 & 7 & $1 / 3$ & 9 & 3 \\
\hline & $\overline{I_{2}}$ & $1 / 5$ & 1 & 9 & 3 & 7 & 5 \\
\hline & $I_{3}$ & $1 / 7$ & $1 / 9$ & 1 & 9 & 7 & 5 \\
\hline & $I_{4}$ & 3 & $1 / 3$ & $1 / 9$ & 1 & 7 & 5 \\
\hline & $I_{5}$ & $1 / 9$ & $1 / 7$ & $1 / 7$ & $1 / 7$ & 1 & 5 \\
\hline & $I_{6}$ & $1 / 3$ & $1 / 5$ & $1 / 5$ & $1 / 5$ & $1 / 5$ & 1 \\
\hline
\end{tabular}

Čia išsilavinimas $-I_{I}$, technologijų naudojimas darbe $-I_{2}$, profesiné patirtis $-I_{3}$, pareigu lygis $-I_{4}$, darbuotojo darbo užmokestis $-I_{5}$, kvalifikacijos tobulinimas $-I_{6}$.

Ekspertai vertino darbuotojo žinių veiksnių rodiklius pagal pasirinktą vertinimo skalę nuo 0 iki 9. Kiekvienas skaitinis įvertis atitinka kokybinį (žodinị, lingvistinį) vertinimą. Esant didesniam rodiklių skaičiui patogu rinktis skalę turinčią daugiau skaitinių reikšmių.

Ekspertu nuomoniu suderinamumo laipsnio nustatymas. Tarpusavio ekspertu nuomoniu suderinamumo patikrinimas būtinas jeigu jomis remiantis priimamas sprendimas. Taikant SAW ir AHP metodus rekomenduojama patikrinti visu ekspertų nuomoniu suderinamumą. Po pirmojo nuomoniu suderinamumo skaičiavimo - pagal 4.3 lenteleje rekomenduojamus žingsnius - konkordancijos koeficiento $W$ reikšmé arteja prie nulio, t. y. $W=0,0674$ (4.12 lentelè). Todèl ekspertų buvo paprašyta pakartotinai užpildyti lenteles.

4.12 lentelè. Ekspertų nuomonių suderinamumo apskaičiavimo rezultatai vertinant išreikštinių žinių bloko veiksnius SAW metodu (sudaryta autorès)

Table 4.12. Expert opinion compatibility calculation results taking into consideration knowledge block factors by SAW method (compiled by the author)

\begin{tabular}{|l|c|c|l|l|l|l|l|}
\hline $\begin{array}{l}\text { Tikrinimu } \\
\text { skaičius }\end{array}$ & $x_{i}$ & $\bar{x}$ & $S$ & $S_{\max }$ & $W$ & $X^{2}$ & $\begin{array}{l}\text { Nuomonių } \\
\text { suderinamumas }\end{array}$ \\
\hline I tikrinimas & 225 & 37,5 & 95,5 & 1457,9 & 0,0674 & 3,0317 & Nesuderintos \\
\hline II tikrinimas & 189 & 31,5 & 575 & 1457,9 & 0,4056 & 18,254 & Suderintos \\
\hline
\end{tabular}

Po antrojo ekspertų nuomonių suderinamumo apskaičiavimo išreikštinių Žinių bloko veiksnių konkordancijos koeficientas yra 0,4056, o tai rodo, jog ekspertu nuomonès suderintos silpnai, todèl papildomai apskaičiuojama $X^{2}$ (4.1 formulè), o $X_{k r}^{2}$ reikšmès naudojamos iš skirstinio lentelès pagal 
reikšmingumo lygmeni $\alpha$ (praktikoje $\alpha$ reikšmė iprastai yra 0,05 arba 0,01 ) ir laisvès laipsnį $v=m-1$ (Евланов, Кутузов 1978).

$$
X^{2}=W \cdot p \cdot m \cdot(m-1) .
$$

Jei apskaičiuota pagal (4.1) formulę $X^{2}$ reikšmè didesnè už $X^{2}{ }_{k r}$, tai ekspertų vertinimai yra suderinti. Pagal pasirinktą reikšmingumo lygmenį $\alpha=0,05$ su laisvès laipsniu $v=5$ ir $X^{2}<X^{2}{ }_{k r}$ rodo jog pirmu ekspertu nuomonių suderinamumo apskaičiavimu yra nesuderintos, o antru pakartotiniu apskaičiavimu - suderintos, nes $X^{2}>X^{2}{ }_{k r}$.

Atlikus apklausą mažų organizacijų anketų grį̌tamumas šimtaprocentinis, deja, didelių - VI „X miškų urèdija“ ir „Kiverco“ - ne. Apskaičiuotas reprezentatyvus imties dydis yra tinkamas duomenų analizei (4.13 lentelè).

4.13 lentelė. Anketu grižtamumas (sudaryta autorès)

Table 4.13. Reversability of questionnaires (compiled by the author)

\begin{tabular}{|l|l|l|l|l|l|}
\hline $\begin{array}{l}\text { Anketų Organizacijos } \\
\text { grižtamumo } \\
\text { kiekio tipas }\end{array}$ & $\begin{array}{l}\text { VI „X } \\
\text { miškü } \\
\text { uredija“ }\end{array}$ & $\begin{array}{l}\text { UAB } \\
\text { „Skrema“ }\end{array}$ & $\begin{array}{l}\text { "Geelong } \\
\text { Garage } \\
\text { Doors“ }\end{array}$ & „Kiverco“ & „Flower- \\
box“
\end{tabular}

Apklausus i̇monių darbuotojus paaiškejjo, kad net $72 \%$ darbuotojų turi aukštaji universitetinį išsilavinimą, iš jų $44 \%$ - magistro laipsni ir $28 \%$ bakalauro laipsnị.

Normalizuoti veiksniu jeverčiai. Gauti duomenys normalizuoti ir apskaičiuota kiekvienos tirtos organizacijos darbuotojų žinių apibendrinantysis įvertis (4.14 lentelè). 
4.14 lentelè. Darbuotojų žinių apibendrinančiojo įverčio pasiskirstymas organizacijose taikant SAW metodą (sudaryta autorès)

Table 4.14. Distribution of employee knowledge summarising estimate in organisations through applied SAW method (compiled by the author)

\begin{tabular}{|c|c|c|c|}
\hline \multirow[b]{2}{*}{ Organizacijos } & \multicolumn{2}{|l|}{ SAW } & \multirow{2}{*}{$\begin{array}{l}\text { Apibendrinantis } \\
\text { ivertis }\end{array}$} \\
\hline & $\begin{array}{l}\text { Išreikštinių žinių } \\
\text { bloko veiksnių } \\
\text { iverčiai }\end{array}$ & $\begin{array}{l}\text { Neišreikštinių } \\
\text { žinių bloko } \\
\text { veiksnių įverčiai }\end{array}$ & \\
\hline VI ,X miškų urèdija“" & 161,49 & 181,68 & 343,17 \\
\hline UAB ,Skrema“" & 22,2 & 43,39 & 65,61 \\
\hline „Geelong Garage Doors“ & 33,97 & 74,97 & 108,94 \\
\hline „Kiverco“ & 196,44 & 219,64 & 416,07 \\
\hline „Flowerbox“" & 15,78 & 29,56 & 45,34 \\
\hline
\end{tabular}

Didelių organizacijų darbuotojų žinių îvertis yra gana aukštas, bet tai natūralu, nes, lyginant su mažomis organizacijomis, darbuotojų skaičius yra didesnis, todèl, norint palyginti organizacijų darbuotojų žinias, būtina eliminuoti darbuotojų skaičių atliekant ịverčių redukavimą (4.15 lentelè).

4.15 lentelė. Redukuoto ir normalizuoto darbuotojų žinių apibendrinančiojo ịverčio pasiskirstymas organizacijose taikant SAW metodą (sudaryta autorès)

Table 4.15. Distribution of employee knowledge reduced and normalised summarising estimate in organisations through applied SAW method (compiled by the author)

\begin{tabular}{|c|c|c|c|c|c|c|}
\hline \multirow[b]{3}{*}{ Organizacijos } & \multicolumn{4}{|l|}{ SAW } & \multirow{2}{*}{\multicolumn{2}{|c|}{$\begin{array}{l}\text { Apibendrinantis } \\
\text { ivertis }\end{array}$}} \\
\hline & \multicolumn{2}{|c|}{$\begin{array}{l}\text { Išreikštiniu žinių } \\
\text { bloko veiksnių } \\
\text { iverčiai }\end{array}$} & \multicolumn{2}{|c|}{$\begin{array}{l}\text { Neišreikštinių žinių } \\
\text { bloko veiksnių } \\
\text { iverčiai }\end{array}$} & & \\
\hline & $\begin{array}{l}\text { Redu- } \\
\text { kuotas } \\
\text { ivertis } \\
\end{array}$ & $\begin{array}{l}\text { Normali- } \\
\text { zuotas } \\
\text { ivertis }\end{array}$ & $\begin{array}{l}\text { Redu- } \\
\text { kuotas } \\
\text { ivertis } \\
\end{array}$ & $\begin{array}{l}\text { Normali- } \\
\text { zuotas } \\
\text { ivertis } \\
\end{array}$ & $\begin{array}{l}\text { Redu- } \\
\text { kuotas } \\
\text { ivertis }\end{array}$ & $\begin{array}{l}\text { Normali- } \\
\text { zuotas } \\
\text { ivertis } \\
\end{array}$ \\
\hline $\begin{array}{l}\text { VI, „X mišku } \\
\text { uredija“ }\end{array}$ & 1,9225 & 0,18814 & 2,1629 & 0,12719 & 4,0854 & 0,31533 \\
\hline $\begin{array}{l}\text { UAB } \\
\text { „Skrema“ }\end{array}$ & 2,0182 & 0,19751 & 3,9445 & 0,23197 & 5,9627 & 0,42947 \\
\hline $\begin{array}{l}\text { "Geelong } \\
\text { Garage } \\
\text { Doors" }\end{array}$ & 1,9982 & 0,19555 & 4,4100 & 0,25934 & 6,4082 & 0,45490 \\
\hline „Kiverco“ & 2,0252 & 0,19819 & 2,2643 & 0,13316 & 4,2895 & 0,33135 \\
\hline „Flowerbox" & 2,2543 & 0,22061 & 4,2229 & 0,24834 & 6,4771 & 0,46895 \\
\hline
\end{tabular}


Aukšti išreikštinių žinių bloko įverčiai (4.16 lentelè) rodo, kad tokie veiksniai kaip išsilavinimas, technologijų naudojimas darbe, profesinè patirtis, kvalifikacijos tobulinimas, darbuotojo darbo užmokestis, pareigų lygis yra gana aukšto lygio, t. y. darbuotojai turi pakankamą išsilavinimą, atlikdami darbą naudoja technologijas, turi didelę profesinę patirti darbe, dažnai tobulina kvalifikaciją įvairiuose kursuose ir seminaruose. Žemi šio bloko įverčiai rodo, kad vadovybei reikètu priimti sprendimus veiksnių rezultatų gerinimui, t. y. peržiūrèti visų darbuotojų išsilavinimo lygmenį ir suteikti galimybę studijuoti, paraginti naudotis technologijomis ir ieškoti sprendimų darbuotojų kvalifikacijai tobulinti. Aukšti neišreikštinių žinių bloko ịverčiai rodo didelę motyvaciją dirbti, savarankiškumą darbe, darbuotojų iniciatyvą siekiant organizacijos tikslų bei stiprų norą juos ịgyvendinant, aukštų rezultatų siekimą prisiimant atsakomybę už savo atliktas užduotis, sugebèjimą dirbti sudètingą darbą laikantis darbo kultūros. Žemi neišreikštinių žinių bloko įverčiai rodo, kad vadovybei reiktų priimti sprendimus susijusius su darbuotojų skatinimu, taip keliant motyvaciją ir norą siekti aukštų rezultatų, burti kolektyvą bendroms veikloms, kuriant betarpišką darbuotojų bendravimą, akcentuoti tikslų siekimo svarbą ir iniciatyvos vertes. Esant vidutiniškiems abiejų žinių blokų ịverčiams vadovybẻ gali išlaikyti status $q u o$, bet turètų nuolat stebèti situaciją organizacijoje, pvz., apklausiant darbuotojus.

Iverčių intervalo žingsnis apskaičiuojamas kaip maksimalios ir minimalios ivverčių reikšmių skirtumas dalijamas iš intervalų skaičiaus, t. y. apskaičiuojama pagal formulę:

$$
h=\frac{x_{\max }-x_{\min }}{k},
$$

čia $h$ - ivverčių intervalo žingsnis, $x_{\max }$ - didžiausias veiksnių įvertis, $x_{\min }-$ mažiausias veiksnių įvertis, $k$ - intervalų skaičius.

Intervalų taškai $t_{n}, n=1,2,3, \ldots k$ nustatomi taip:

$$
\begin{aligned}
& t_{1}=x_{\text {min }}, \\
& t_{2}=t_{1}+h, \\
& t_{3}=t_{2}+h, \\
& \cdots \\
& t_{k}=t_{k-1}+h<=x_{\max } .
\end{aligned}
$$

Taigi, $h=0,04405$, o apskaičiuoti intervalai bei jų lingvistinès reikšmès pateiktos 4.16 lentelèje.

Tirtose organizacijose išreikštinių žinių bloko įverčiai tik „Flowerbox“ yra pakankamai aukšti, todèl galima teigti, kad darbuotojai turi pakankamą išsilavinimo lygi, didelę profesinę patirtị, darbe naudoja technologijas, nuolatos tobulina kvalifikaciją, yra patenkinti darbo užmokesčiu. Organizacijų - VI „,X miškų urèdija“, „Geelong Garage Doors“, UAB „Skrema“ ir „Kiverco“- 
išreikštinių žinių bloko įverčiai yra vidutiniai, todèl vadovybei vertètų nuolat stebèti situaciją.

4.16 lentelè. Iverčiai ir jų reikšmès (sudaryta autorès)

Table 4.16. Estimates and their meanings (compiled by the author)

\begin{tabular}{|c|c|c|c|}
\hline $\begin{array}{l}\text { Skaitiniai ịverčių } \\
\text { dydžiai/Intervalas }\end{array}$ & {$[0,12719 ; 0,17124)$} & {$[0,17124 ; 0,21529)$} & {$[0,21529 ; 0,25934]$} \\
\hline $\begin{array}{l}\text { Lingvistiniai } \\
\text { iverčiu dydžiai }\end{array}$ & Žemi & Vidutiniai & Aukšti \\
\hline $\begin{array}{l}\text { Organizaciju } \\
\text { išreikštinių žinių } \\
\text { veiksnių îverčiai } \\
\text { patenkantys ị } \\
\text { intervalą }\end{array}$ & - & $\begin{array}{c}\text { VI „X mišku } \\
\text { uredija“ } \\
\text { „Geelong Garage } \\
\text { Doors“ } \\
\text { UAB „Skrema“ } \\
\text { „Kiverco“ }\end{array}$ & „Flowerbox“ \\
\hline $\begin{array}{l}\text { Organizacijų } \\
\text { neišreikštinių } \\
\text { žiniu veiksnių } \\
\text { iverčiai } \\
\text { patenkantys ì } \\
\text { intervalą }\end{array}$ & $\begin{array}{l}\text { VI! „X mišku } \\
\text { uredija““ } \\
\text { „Kiverco“ }\end{array}$ & - & $\begin{array}{c}\text { UAB „Skrema“ } \\
\text { „Geelong Garage } \\
\text { Doors“ } \\
\text { „Flowerbox“ }\end{array}$ \\
\hline
\end{tabular}

Neišreikštinių žinių bloko įvertis VI „X miškų urėdija“, „Kiverco“ yra žemas, ir tai signalizuoja apie žinių perdavimo, darbuotojų bendradarbiavimo, motyvavimo, savarankiškumo problemas, todèl vadovybei reikètų atkreipti dèmesį i neišreikštinių žinių bloko veiksnių stiprinimą, t. y. tikslinga motyvuoti darbuotojus, skatinti bendradarbiauti siekiant ivairiapusès naudos. Šių organizacijų vadovybei vertetų skirti dèmesi komandos formavimo ir lyderystès aspektams, siekiant didesnio darbuotojų potencialo panaudojimo.

Vienoje organizacijose - „Flowerbox“ - išreikštinių ir neišreikštinių žinių blokų ịverčių skirtumas mažiausias, o ịverčiai priskirtini prie aukštų. Tai rodo jog šiems žinių blokams skiriamas vienodas demesys, t. y. darbuotojai turi tinkamą išsilavinimą, darbe dažnai naudoja technologijas, turi pakankamą profesinę patirti ir gauna pakankamą darbo užmokestį, nuolatos tobulina kvalifikaciją, siekia organizacijos tikslų, yra savarankiški ir prisiima atsakomybę už savo sprendimus, turi pakankamą motyvaciją dirbti, todèl veiklos keitimo sprendimai nebūtini. 


\subsection{Organizacijos darbuotojų žinių sinergijos vertinimo rezultatų interpretacija ir priemonių rinkinys}

Pritaikius sukurtą metodologiją ir ivvykdžius eksperimentą organizacijose apskaičiuoti galutiniai organizacijų darbuotojų žinių sinergijos pagal 2.5 formulę ivverčiai (4.17 lentelè).

4.17 lentelè. Galutinio įverčio pasiskirstymas organizacijose (sudaryta autorès)

Table 4.17. Distribution of final estimate in organisations (compiled by the author)

\begin{tabular}{|l|c|c|c|}
\hline Organizacijos & $\begin{array}{l}\text { Iverčiai } \\
\text { žinių ivverčiai, } \hat{Z}\end{array}$ & $\begin{array}{l}\text { Ryšių tarp } \\
\text { darbuotojų } \\
\text { iverčiai, } R\end{array}$ & $\begin{array}{l}\text { Apibendrinantis } \\
\text { ivertis, } S_{\check{z}}\end{array}$ \\
\hline VI! „X miškų uredija“ & 343,17 & 341 & 100,64 \\
\hline UAB „Skrema“ & 65,61 & 64 & 102,52 \\
\hline „Geelong Garage Doors“ & 108,94 & 99 & 110,04 \\
\hline „Kiverco“ & 416,07 & 583 & 71,37 \\
\hline „Flowerbox“ & 45,34 & 36 & 125,94 \\
\hline
\end{tabular}

Pagal kiekvienos organizacijos žinių sinergijos ịverčių lygi, nustatytas organizacijos darbuotojų žinių sinergijos lygio stiprumas ir organizacijos darbuotojų žinių sinergijos apibendrinančio ivverčio pasiskirstymas, rodantis organizacijos darbuotojų žinių sinergijos stiprumą tirtose organizacijose (4.4 pav.).

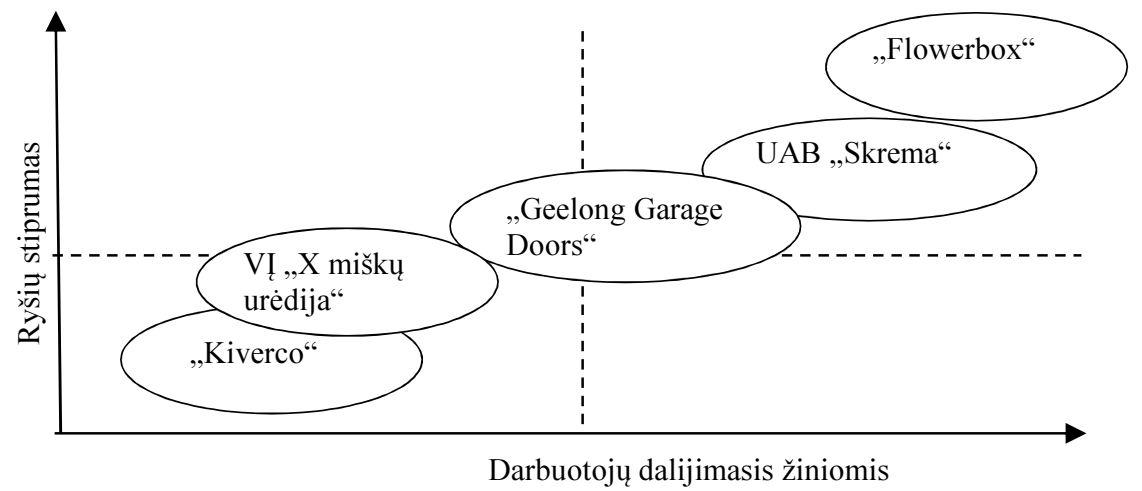

4.4 pav. Organizacijos žinių sinergijos galutinio ịverčio pasiskirstymas (sudaryta autorès)

Fig. 4.4. Distribution of final estimate of organisation knowledge synergy (compiled by the author) 
Apibendrinant gautus rezultatus galima teigti, jog dalijantis žiniomis žinių sinergija yra stipresnè mažoje grupeje (4.5 pav.). Vis dèlto tokioje grupejje laikui bègant gali pritrūkti nuomonių ir idèjų, todèl būtinas nuolatinis kvalifikacijos kèlimas ir naujų žinių gavimas bei nuolatinè organizacijos aplinkos (ypač technologinès, socialinès, taip pat konkurencinès ir kt.) kitimo stebėsena.

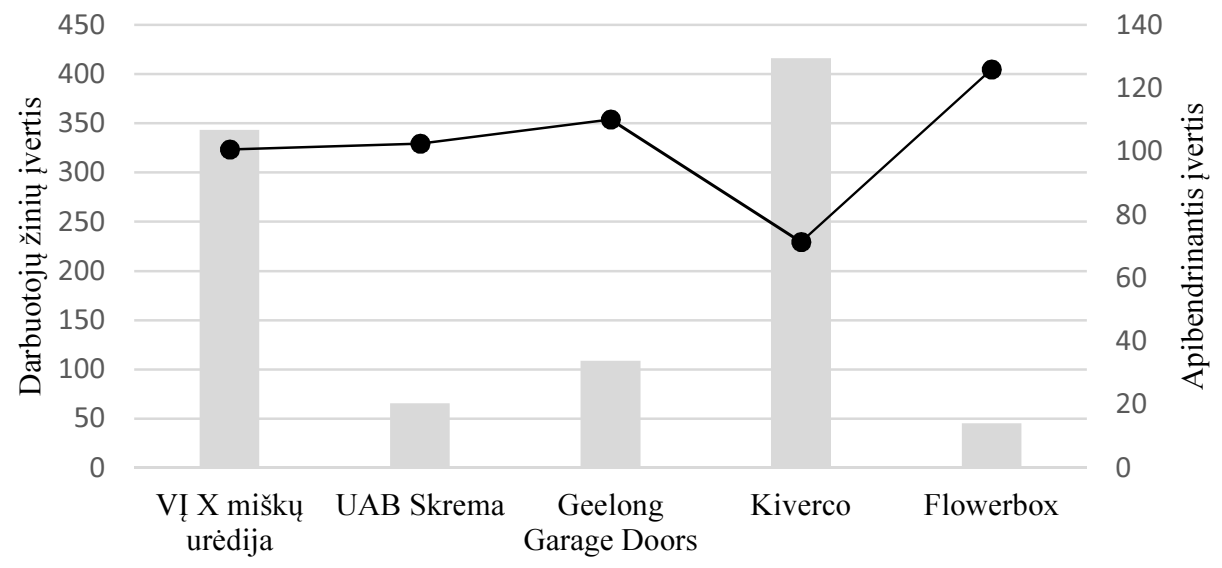

Darbuotojų žinių įvertis $\longrightarrow$ Žinių sinergijos įvertis

4.5 pav. Darbuotojų žinių ir žinių sinergijos palyginimas

Fig. 4.5. Comparison of employee knowledge and knowledge synergy

Vykdant apklausą nustatyti ir respondentų lūkesčiai. Atsakydami ị klausimą „Ko tikimasi iš vadovo ir kolegų, siekiant pagerinti bendradarbiavimą ir žinių dalijimąsi?“", darbuotojai nurodè, kad labiausiai tikisi iš vadovų tolerancijos $(16 \%)$, supratimo $(15 \%)$ ir geranoriškumo $(17 \%)$, tuo tarpu vadovai iš darbuotojų tikisi motyvacijos (15\%), iniciatyvos (12\%), atvirumo naujovèms (10\%), drąsos veikti ( $8 \%)$ (4.6 pav.).

Apibendrinant tyrimo rezultatus galima teigti, kad tiek darbuotojai, tiek vadovai turètu siekti artimesnio ir nuoširdesnio tarpusavio dialogo, o norint didesnio sinergijos efekto būtinas permanentinis ir betarpiškas dalijimasis žiniomis ir naujų žinių kūrimas. Organizacijos vadovybei tikslinga peržiūrèti veiklos strategiją, identifikuoti silpnybes ir stiprybes, sekti dinamišką ir įvairialypi rinkos kitimą, nuolat vertinti darbuotojų žinias, suteikti galimybę igyti naujų žinių. 


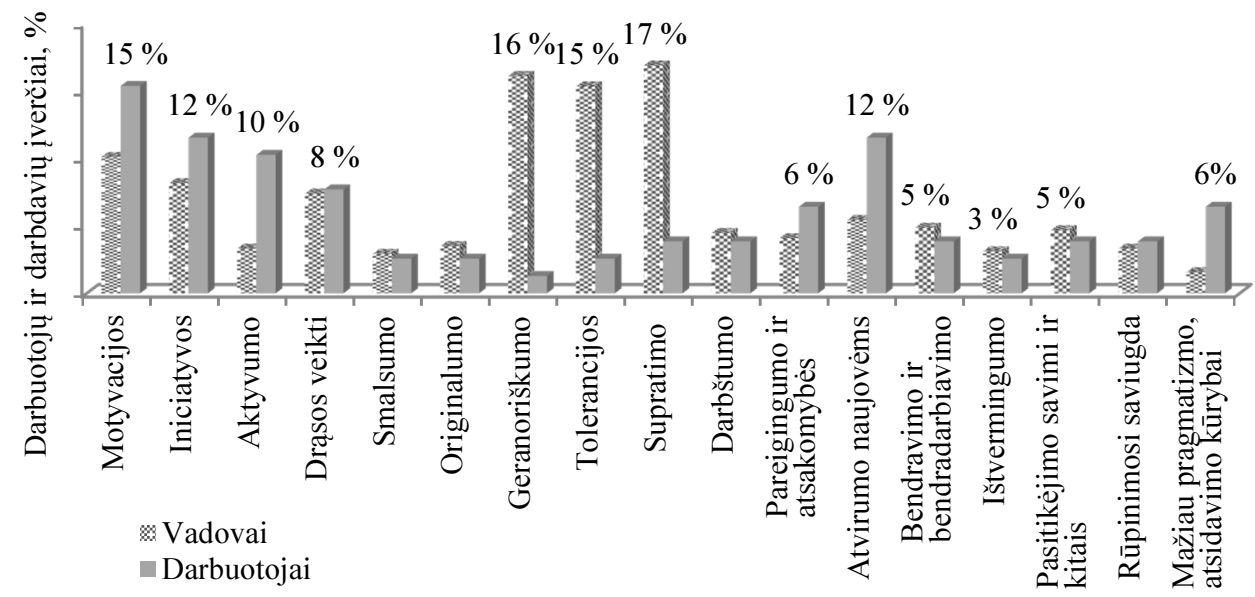

4.6 pav. Vadovų ir darbuotojų lūkesčių pasiskirstymas (sudaryta autorès)

Fig. 4.6. Distribution of expectations of managers and employees

(compiled by the author)

Atlikus išsamius žinių sinergijos tyrimus ir apžvelgus eksperimentinius tyrimų rezultatus tikslinga taikyti siūlomas žinių sinergijos stiprinimo priemones (4.18 lentelè).

4.18 lentelè. Žinių sinergijos stiprinimo priemonès (sudaryta autorès)

Table 4.18. Means of building knowledge synergy (compiled by the author)

\begin{tabular}{|c|c|c|}
\hline Žinių ciklo etapai & Priemonè & Priemonès pagrindimas \\
\hline $\begin{array}{l}\text { Žinių } \\
\text { identifikavimas }\end{array}$ & $\begin{array}{l}\text { Nauji žinių } \\
\text { valdymo/vertinimo/ } \\
\text { strategijų modeliai }\end{array}$ & $\begin{array}{l}\text { Neišreikštos žinios bus tiksliau } \\
\text { identifikuojamos ir pateikiamos } \\
\text { suprantama forma }\end{array}$ \\
\hline \multirow[t]{2}{*}{$\begin{array}{l}\text { Žinių } \\
\text { kūrimas }\end{array}$} & Inovacijos & $\begin{array}{l}\text { Atkreipiamas dèmesys ị idèjas, kurios } \\
\text { atrodo kaip netinkamos }\end{array}$ \\
\hline & Mokymasis dirbant & $\begin{array}{l}\text { Išreikštinès, o ypatingai neišreikštinès } \\
\text { žinios perduodamos vieno darbuotojo } \\
\text { kitam }\end{array}$ \\
\hline $\begin{array}{l}\text { Žinių } \\
\text { saugojimas }\end{array}$ & $\begin{array}{l}\text { Netradiciniai } \\
\text { mokymosi metodai }\end{array}$ & $\begin{array}{l}\text { Išsaugotos žinios tampa prieinamos } \\
\text { visiems }\end{array}$ \\
\hline $\begin{array}{l}\text { Žinių } \\
\text { skleidimas }\end{array}$ & $\begin{array}{l}\text { Atviras } \\
\text { bendradarbiavimas }\end{array}$ & $\begin{array}{l}\text { Žinios patikrinamos - klaidingos } \\
\text { atmetamos, teisingos naudojamos }\end{array}$ \\
\hline
\end{tabular}


Nauji žinių valdymo/vertinimo/strategijų modeliai sudarys sąlygas greičiau identifikuoti darbuotojo žinias, o tai skatins naujų žinių kūrimą. Išsaugotos žinios bus prieinamos visiems organizacijos darbuotojams, todèl mažès klaidų tikimybè. Organizacijos darbuotojai aktyviai ir besąlygiškai dalinsis žiniomis, kurdami savitą organizacijos aplinką, kultūrą, sudarydami sąlygas atsirasti žinių sinergijai.

\subsection{Ketvirtojo skyriaus išvados}

1. Siekiant atlikti organizacijos darbuotojų žinių vertinimą, taikant daugiakriterinio vertinimo metodus, sudarytas algoritmas iš keturių etapu Pirmasis etapas skirtas pasiruošimui, t. y. susipažinimas su vadovybe, organizacijos struktūra, žinių tyrimo svarbos ir numatomų rezultatų poreikio aptarimas. Antrasis etapas skirtas konsultavimui, t. y. pokalbiui su ekspertu grupe ir darbuotojais. Kitu - trečiuoju - etapu vykdomos ekspertų bei darbuotojų apklausos ir duomenų rinkimas iš organizacijos informacinès sistemos (IS) bei skaičiuojamas duomenų matricu ir ekspertų nuomonių suderinamumas. Jeigu ekspertų nuomonès nesuderintos, grịžtama i antraji etapą, jeigu nuomonès suderintos - vykdomas rezultatų interpretavimas. Ketvirtuoju etapu duomenys apdorojami ir organizacija supažindinama su vertinimo rezultatais, remiantis kuriais vadovybė gali priimti darbuotojų veiklos efektyvinimo sprendimus: koreguoti ar keisti tikslus, nustatyti naujus uždavinius susijusius su darbuotojų kvalifikacijos gerinimu, karjeros keitimu bei pačios organizacijos stiprybių užtvirtinimu ir silpnybių eliminavimu.

2. Organizacijos darbuotojų žinioms, suklasifikuotoms i išreikštinių ir neišreikštinių žinių blokus, šių blokų veiksnių bei jų dedamujjų vertinimui ir sujungimui ị vieną apibendrintaji ịverti parengta metodika. Jos taikymas leidžia kompleksiškai îvertinti ir kiekybiškai išmatuoti organizacijos darbuotojų žinias. Veiksnių reikšmingumams nustatyti siūlomi taikyti SAW, AHP daugiakriteriniai vertinimo metodai sudaro sąlygas ịvairiais pjūviais palyginti, analizuoti organizacijos darbuotojų žinias. SAW metodo taikymas sudaro sąlygas sujungti organizacijos darbuotoju žinių veiksnius ị vieną apibendrintaji ịvertį, o AHP metodo taikymas papildo SAW metodą - darbuotojo žinių veiksniai struktūruojami ir ịvertinami poriniu būdu. Šių metodų taikymas leidžia nustatyti organizacijai savo darbuotojų stiprybes ir silpnybes, o apibendrintas ịvertis leidžia atlikti lyginamają ịvairių organizacijų analizę.

3. Atlikus darbuotojų žinių blokų ekspertinị vertinimą išreikštinių žinių blokui suteiktas 0,41 ịvertis, o neišreikštinių žinių blokui - 0,59. Tai rodo, jog ekspertai teikia pirmumą darbo kultūrai, darbuotojų motyvacijai bei tikslų siekimui, savarankiškumui dirbti. Darbuotojo darbui atlikti ypatingai svarbūs yra profesinès 
patirties, motyvacijos ir savarankiškumo darbe veiksniai. Didžiausią reikšmingumą igijo išreikštinių žinių bloko „Profesinès patirties“ veiksnys $(0,28)$, o neišreikštinių žinių bloko - „Motyvacija dirbti““ $(0,22)$.

4. Atlikto eksperimento metu apskaičiuoti organizacijų žinių blokų įverčiai suskirstyti ị tris grupes: aukšti, vidutiniai ir žemi. Aukšti atitinkamo žinių bloko ivverčiai rodo, kad organizacijoje vykstančių žinių procesų keitimas nebūtinas. Esant vidutiniškiems žinių bloku ivverčiams vadovybè turètų nuolat stebèti situaciją organizacijoje. Žemi žinių blokų įverčiai rodo, kad vadovybei reiktų priimti sprendimus veiksnių rezultatų gerinimui.

5. Atlikus organizacijos žinių sinergijos galutinio ịverčio pasiskirstymo analizę galima teigti, kad mažose organizacijose tiek ryšiai tarp darbuotojų, tiek žinių sinergija yra stiprūs. Vis dèlto tokioje grupeje laikui bègant gali pritrūkti nuomonių ir idejjų, todèl būtinas nuolatinis kvalifikacijos kèlimas ir naujų žinių gavimas bei nuolatinis rinkos, technologijų kitimo sekimas. 


\section{Bendrosios išvados}

1. Žinių srities tyrimams taikomi ịvairūs terminai, kurie yra labiau epizodiniai, todèl atlikus įvairių mokslininkų žinių sampratos analizę, nustatyti žinių tipai ir išgryninta nauja žinių apibréžtis - tai asmens pažinimo proceso išraiška, formuojama asmeninių charakteristikų ir ji supančios aplinkos bei sudaranti prielaidas asmeniui veikti. Išgrynintas žinių sinergijos apibrěžimas: tai išreikštinių ir neišreikštiniu žinių sąveikos procesų, darančių įtaką asmens ar organizacijos veiklai ir kuriančių naujas žinias, rezultatas. Siūlomi žinių ir žinių sinergijos apibrezžimai ne tik atskleidžia sąsajas tarp žinių ir žinių sinergijos, bet ir sudaro prielaidas nustatyti žinių sinergijos dedamąsias ir plètoti žinių sinergijos vertinimo tyrimus.

2. Darbuotojui esant aktyviam bei perduodant žinias kitiems, pastarosios tampa visiems žinomos, praranda savo vertę bei unikalumą, o keičiantis technologijoms - sensta. Visuose keturiuose - identifikavimo, kūrimo, saugojimo, skleidimo - žinių valdymo etapuose nustatyta žinių nutekèjimo, nuvertejjimo, priklausomybès, pasitikèjimo žiniomis probleminès sritys. Organizacijai, siekiančiai sujungti darbuotojų žinias ir naudoti jas veiklai vykdyti, vertei kurti bei veiksmingai išnaudoti žinių sinergiją būtina atkreipti dèmesị ir sistemiškai nagrinèti žinių problemines sritis visuose žinių valdymo etapuose.

3. Atlikta žinių sinergijos vertinimo metodinès bazès analizè leido konstatuoti žinių sinergijos vertinimo tyrimų nepakankamą išbaigtumą ir kartu išgryninti 
esminius organizacijos darbuotojų žinių sinergijos vertinimo komponentus darbuotojo žinias ir ryšius tarp darbuotojų. Šių komponentų pagrindu pasiūlyta žinių sinergijos vertinimo schema ir vertinimo metodika, sudaro prielaidas racionaliai ir objektyviai ịvertinti žinių sinergiją. Atlikta žinių sinergijos komponentų vertinimo metodinès bazès analizè sudare prielaidas pateikti tokius siūlymus:

3.1. Darbuotojų žinių vertinimą tikslinga vykdyti grupuojant veiksnius ị išreikštinių ir neišreikštinių žinių blokus, o tai sudaro sąlygas kompleksiškai bei objektyviai ịvertinti darbuotojo žinias.

3.2. Siekiant racionaliai ịvertinti ryšius tarp darbuotojų būtina: išskirti ryšių tipus; atsižvelgiant i darbuotojų ryšių tipą, taikyti efektyvių ryšių skaičiavimo metodą, t. y. asmens ir grupès ryšiams apskaičiuoti taikyti organizacijos struktūrų analize grịstą metodą, o pavienių darbuotojų ryšiams apskaičiuoti - vadybos teorijos normomis gristą metodą.

4. Organizacijos darbuotojų žinioms, suskirstytoms ị du blokus: išreikštinių ir neišreikštinių, šių blokų veiksnių bei jų dedamujų vertinimui ir sujungimui i bendrą ịverti parengta metodika leidžia kompleksiškai ịvertinti ir kiekybiškai išmatuoti organizacijos darbuotojų žinias. Darbuotojų žinių vertinimui taikomas daugiakriterinių vertinimo metodų - SAW, AHP - rinkinys, sudaro sąlygas ivairiais pjūviais palyginti, analizuoti organizacijos darbuotojų žinias: SAW metodo taikymas sudaro sąlygas apjungti organizacijos darbuotojų žinių veiksnius i vieną apibendrintaji ịverti; AHP metodo taikymas papildo SAW metodą darbuotojo žinių veiksniai struktūruojami ir ịvertinami poriniu būdu. Darbuotojų žinių vertinimas leidžia nustatyti organizacijai darbuotojų stiprybes ir silpnybes, o galimybe apskaičiuoti apibendrintą įvertị sudaro sąlygas dinaminei analizei stebint organizacijos pokyčius bei lyginamajai analizei su kitomis organizacijomis.

5. Atliktas eksperimentas patvirtino, kad parengta standartizuota organizacijos darbuotojų žinioms vertinti metodika yra pritaikoma ịvairioms organizacijoms. Aukšti išreikštinių žinių bloko ịverčiai rodo, kad darbuotojai turi pakankamą išsilavinimą, atlikdami darbą naudoja technologijas, turi sukaupę didelę profesinę patirtį, dažnai tobulina kvalifikaciją ivvairiuose kursuose ir seminaruose, o atlyginimas patekina darbo lūkesčius. Žemi šio bloko ịverčiai rodo, kad vadovybei reiktų priimti sprendimus veiksnių rezultatų gerinimui, t. y. peržiūrèti visų darbuotojų išsilavinimo lygmenị ir suteikti galimybę studijuoti, paraginti naudotis technologijomis ir ieškoti sprendimų darbuotojų kvalifikacijai tobulinti. Aukšti neišreikštinių žinių bloko ịverčiai rodo didelę motyvaciją dirbti, savarankiškumą darbe, darbuotojų iniciatyvą siekiant organizacijos tikslų bei stiprų norą juos ịgyvendinant, aukštų rezultatų siekimą prisiimant atsakomybę už savo atliktas užduotis, sugebejjimą dirbti sudètingą darbą laikantis darbo kultūros. Žemi neišreikštinių žinių bloko įverčiai rodo, kad vadovybei reikètų priimti 
sprendimus, susijusius su darbuotojų skatinimu, taip keliant darbuotojų motyvaciją ir norą siekti aukštų rezultatų. Taip pat vadovybė turètų burti kolektyvą bendroms veikloms, kuriant betarpišką darbuotojų bendravimą, turetų akcentuoti tikslų siekimo svarbą ir iniciatyvos vertę. Esant vidutiniškiems abiejų žinių blokų ịverčiams vadovybė gali išlaikyti status quo, bet kartu ji turètų nuolat stebėti situaciją organizacijoje, pvz., apklausiant darbuotojus. 



\section{Literatūra ir šaltiniai}

Abraham, S. E.; Karns, L. A.; Shaw, K.; Mena, M. A. 2001. Managerial competencies and the managerial performance appraisal process, Journal of Management Development 20(10): 842-852.

Ackoff, R. L. 1989. From Data to Wisdom, Journal of Applies 16(3): 3-9.

Albrect, T L.; Johnsson, M. G.; Walther, J. B. 1993. Understanding communication processes in focus groups, in Advancing the State of the Art. Sage publications: Newbury park.

Alkin, M. C. (ed.). 2004. Evaluation Roots - Tracing Theorists' Views and Influences. Sage Publications.

Andersson, U.; Dasí, À.; Mudambi, R.; Pedersen, T. 2016. Technology, innovation and knowledge: The importance of ideas and international connectivity, Journal of World Business 51(1): 153-162.

Andreeva, T.; Kianto, A. 2011. Knowledge processes, knowledge-intensity and innovation: a moderated mediation analysis, Journal of Knowledge Management 15(6): 1016-1034.

Andriušaitienė, D.; Ginevičienè, V. B.; Šileika, A. 2008. Daugiakriterinis profesinio mokymo kokybès valdymo vertinimo modelis, Verslas: Teorija ir praktika 9(2): 88-96. 
Antucheviciene, J.; Zavadskas, E. K.; Zakarevicius, A. 2010. Multiple criteria construction management decisions considering relations between criteria, Technological and Economic Development of Economy 16(1): 109-125. DOI: 10.3846/tede.2010.07.

Atkočiūnienė, Z. 2009. Informacijos ir žinių vadybos aprèptys: Kaita, sąveika, taikymas. Prieiga per internetą: https://epublications.vu.lt/object/elaba:6230500/6230500.pdf.

Atkočiūnienė, Z. O. 2006. Informacijos ir žinių vadyba informacijos ir komunikacijos mokslų sistemoje, Informacijos mokslai 37: 22-29.

Atkočiūnienè, Z. O. 2013. Žinių vadyba ir organizacijos darna: konkurencinio pranašumo aspektas, Elektroninis mokymasis, informacija ir komunikacija: teorija ir praktika 1: 1527. ISSN 2335-2493.

Atkočiūnienè, Z; Juškaitè, J. 2012. Žinių vadybos vaidmuo organizacijos strateginių kompetencijų plètojimui: atvejo tyrimas, Elektroninis mokymasis, informacija ir komunikacija: teorija ir praktika 1: 58-85. Prieiga per internetą: http://www.esec. vu.lt/straipsniai/index. php/elea rning/issue/view/4.

Augustinaitis, A.; Rudzkienė, V.; Petrauskas, R. A. 2009. Kolektyvine monografija: Lietuvos e. valdžios gairès: ateities ǰžvalgu tyrimas (atsakingieji redaktoriai: Vitalija Rudzkienè, Arūnas Augustinaitis). Mykolo Romerio universitetas.

Baležentis, A.; Baležentis, T. 2011. Assessing the efficiency of Lithuanian transport sector by applying the methods of MULTIMOORA and data envelopment analysis, Transport 26(3): 263-270. ISSN 1648-4142.

Baležentis, T.; Zeng, S. 2013. Group multi-criteria decision making based upon intervalvalued fuzzy numbers: an extension of the MULTIMOORA method, Expert Systems with Applications 40: 543-550. Prieiga per internetą: http://dx.doi.org/10.1016/j.eswa.2012. 07.066

Barata, J.; Cunha, P. R. 2015. Synergies between quality management and information systems: literature review and map for further research, Total Quality Management and Business Excellence: 1-15. DOI: 10.1080/14783363.2015.1080117.

Becerra, M.; Lunnan, R.; Huemer, L. 2008. Trustworthiness, risk, and the transfer of tacit and explicit knowledge between alliance partners, Journal of Management Studies 45: 691-731.

Beers, P. J.; Boshuizen, H. P.; Kirschner, P. A.; Gijselaers, W. H. 2006. Common ground, complex problems and decision making, Group Decision and Negotiation 15(6): 529-556.

Behzadian, M.; Kazemzadeh, R. B.; Albadvi, A.; Aghdasi, M. 2010. PROMETHEE: A comprehensive literature review on methodologies and applications, European Journal of Operational Research 200(1): 198-215.

Bell, D. 1973. The Coming of Post-industrial Society: A Venture in Social Forecasting. New York: Basic Books. 508 p.

Belohlavek, D. 2007. The Unicist Ontology of Intellectual Capital Building. The Unicist Research Institute, Buenos Aires: Blue Eagle Group. 
Belton, V.; Stewart, T. J. 2002. Multiple criteria decision analysis: an integrated approach. Kluwer Academic Publishers.

Bianchi, M. 2010. Perspectives for the extension of Graiciunas' span of control to the process of enterprise creation, Tiltai 4: 15-33.

Biggs, J.; Tang, C. Assessment by portfolio: constructing learning and designing teaching. Prieiga per internetą: https://belmontteach.files.wordpress.com/2013/12/c onstructinglearning-and-designing-teaching-biggs-tang.pdf.

Birasnav, M. 2014. Knowledge management and organizational performance in the service industry: The role of transformational leadership beyond the effects of transactional leadership, Journal of Business Research 67(8): 1622-1629.

Bivainis, J.; Morkvėnas, R. 2008. Darbuotojų žinių potencialo vertinimas, Verslas: Teorija ir praktika 9(2): 105-115.

Björkman, I.; Fey, C. F.; Park, H. J. 2007. Institutional theory and MNC subsidiary HRM practices: evidence from a three-country study, Journal of International Business Studies 38(3): 430-446.

Björkman, I.; Welch, D. 2015. Framing the field of international human resource management research, International Journal of Human Resource Management 26(2): 136-150. DOI:10.1080/09585192.2014.922361.

Bock, G. W.; Zmud, R. W.; Kim, Y. G.; Lee, J. N. 2005. Behavioural intention formation in knowledge sharing: Examining the roles of extrinsic motivators, social psychological forces, and organizational climate, MIS Quarterly 29: 87-111.

Boyatzis, R. E. 1982. The Competent Manager: A Model for Effective Performance. New York: John Wiley \& Sons.

Boyatzis, R. E. 2008. Competencies in the 21st century, Journal of management development, 27(1): 5-12.

Boisot, M. 1998. Knowledge assets: securing competitive advantage in the information economy. New York, NY: Oxford University Press.

Borba, G. S.; Kliemann Neto, F. J. 2008. Gestão Hospitalar: identificação das práticas de aprendizagem existentes em hospitais, Saude e sociedade 17(1): 44-60. Prieiga per internetą: https://dx.doi.org/10.1590/S0104-12902008000100005.

Borgatti, S.; Foster, P. 2003. The network paradigm in organizational research: a review and typology, Journal of management 29(6): 991-1013.

Bornemann, M.; Sammer, M. 2003. Assessment Methodology to Prioritize Knowledge Management Related Activities to Support Organizational Excellence, Measuring Business Excellence 7(2): 45-53. 
Bouyssou, D.; Marchant, T. 2015. On the relations between ELECTRE TRI-B and ELECTRE TRI-C and on a new variant of ELECTRE TRI-B, European Journal of Operational Research 242: 201-211. DOI:10.1016/j.ejor.2014.09.057.

Bouthillier, F.; Shearer, K. 2002. Understanding knowledge management and information management: the need for an empirical perspective, Information Research 8(1): 165-185.

Brans, J. P. 1982. L'ingenierie de la decision; Elaboration d'instruments d'aide a la decision. La methode PROMETHEE, in Nadeau, R. and Landau, M. (Eds.). L'aide a la decision: Nature, Instruments et Perspectives d'Avenir. Quebec, Canada: Presses de l'Universite Laval. 183-213.

Brass, D. J.; Galaskiewicz, J.; Greve, H. R.; Tsai, W. 2004. Taking Stock Of Networks and Organizations: A Multilevel Perspective, Academy of Management Journal 47(6): 795-817.

Brauers, W. K. M.; Zavadskas, E. K. 2006. The MOORA method and its application to privatization in a transition economy, Control and Cybernetics 35(2): 445-469.

Brauers, W. K. M.; Zavadskas, E. K. 2010. Project management by MULTIMOORA as an instrument for transition economies, Technological and Economic Development of Economy 16(1): 5-24.

Brauers, W. K. M.; Zavadskas, E. K.; Peldschus, F.; Turskis, Z. 2008. Multi-objective decision-making for road design, Transport 23(3): 183-193. DOI: 10.3846/16484142.2008.23.183-193.

Brčić, Ž. J.; Mihelič, K. K. 2015. Knowledge sharing between different generations of employees: an example from Slovenia, Economic Research 28(1): 853-867. DOI: 10.1080/1331677X.2015.1092308.

Brigade special troops battalions, Part II: Synergy, The Free Library. 2014. Preiga per internetą: https://www.thefreelibrary.com/Brigade+special+troops+battalions\%2c+Part + II\%3a+synergy.-a0160716018.

Brockmann, M.; Clarke, L.; Winch, Ch. 2009. Competence and competency in the EQF and in European VET systems, Journal of European Industrial Training 33(8/9): 787799.

Büyüközkan, G.; Parlak I. B.; Tolga, A. C. 2016. Evaluation of Knowledge Management Tools by Using An Interval Type-2 Fuzzy TOPSIS Method, International Journal of Computational Intelligence Systems 9(5): 812-826.

Campbell, S. W.; Park, Y. I. 2008. Social Implications of Mobile Telephony: The Rise of Personal Communication Society, Sociology Compass 2(2): 371-387.

Cappettta, R.; Cillo, P.; Ponti, A. 2006. Convergent designs in fine fashion: anevolutionary model for sytlistic innovation, Reserch Policy 35(9): 1273-1290.

Carson, D.; Gilmor, A.; Rocks, S. 2004. SME marketing networking: a strategic approach, InterScience 13: 369-382. 
Castells, M. 2007. Communication, Power and Counter-power in the Network Society, International Journal of Communication 1: 238-266.

Cebi, F.; Otay, I. 2015. Multi-Criteria and Multi-Stage Facility Location Selection under Interval Type-2 Fuzzy Environment: A Case Study for a Cement Factory, International Journal of Computational Intelligence Systems 8: 330-344.

Celik, E.; Aydin, N.; Gumus, A. T. 2014. A multiattribute customer satisfaction evaluation approach for rail transit network: A real case study for Istanbul, Turkey, Transport Policy 36: $283-293$.

Celik, E.; Bilisik, O.; Erdogan, M.; Gumus, A.; Baracli, H. 2013. An integrated novel interval type-2 fuzzy mcdm method to improve customer satisfaction in public transportation for Istanbul, Transportation Research Part E: Logistics and Transportation Review 58: 28-51.

Chawla, D.; Joshi, H. 2011. Impact of knowledge management on learning organization practices in India: an exploratory analysis, The Learning Organization 18(6): 501-516.

Chen, T. Y. 2014. An electre-based outranking method for multiple criteria group decision making using interval type-2 fuzzy sets, Information Sciences 263: 1-21.

Chen, X. H.; Snyman, M. M. M.; Sewdass, N. 2005. Interrelationship between document management, information management and knowledge management, South African Journal of Infomation Management 7(3): 1-19.

Chennamaneni, A.; Teng, J. T. C.; Raja, M. K. 2012. A unified model of knowledge sharing behaviours: Theoretical development and empirical test, Behaviour \& Information Technology, 31(11): 1097-1115.

Chisholm, R.F.; Elden, M. 1993. Features of emerging action research, Human Relations 46 (2): 275-298.

Cho, W.; Shaw, M. J.; Kwon, H. D. 2013. The effect of synergy enhancement on information technology portfolio selection, Information Technology and Management 14: 125-142. DOI: 10.1007/s10799-012-0150-9.

Choo, C. W. 1998. The knowing organization: how organizations use information to construct meaning, create knowledge, and make decisions. New York: Oxford University Press.

Chou, S. Y.; Chang, Y. H.; Shen, C. Y. 2008. A fuzzy simple additive weighting system under group decision-making for facility location selection with objective/subjective attributes, European Journal of Operational Research 189(1): 132-145. DOI: 10.1016/j.ejor.2007.05.006.

Coyne, K. P.; Hall, S. D.; Clifford, P. G. 1997. Is your core competence A MIRAGE?, Mckinsey Quarterly 1: 40-54.

Curley, M. A. 1998. Patient-nurse synergy: optimizing patients' outcomes, American Journal of Critical Care 7(1): 64-72. 
Činčikaitè, R.; Janeliūnienè, R. 2010. Imoniu konkurencingumas žiniu ekonomikos salygomis. Prieiga per internetą: http://leidykla.vgtu.lt/conferences/BME_2010/005/ pdf/Art-Cincikaite_Janeliuniene.pdf.

Čiutienè, R.; Šarkiūnaitè I. 2004. Darbuotojų kompetencija - organizacijos konkurenicngumą lemiantis veiksnys, Ekonomika 67(2): 134-139.

Čivilis, M. 2006. Vadybininko žinių struktūros pokyčiai diegiant organizacijoje informacines technologijas: elastingų žinių atvejis, Informacijos mokslai 38: 52-63.

Dalkir, K. 2005. Knowledge management in theory and practice. Elsevier. 356 p.

Damodaran, A. 2005. The Value of Synergy. Prieiga per internetą: https://dx.doi.org/10.2139/ssrn.841486.

Danciu, V. 2013. The sustainable company: new challanges and strategies for more sustainability, Theoretical and Applied Economics 9: 7-26.

Dave, M.; Dave, M.; Shishodia, Y. S. 2012. Knowledge Management and Organizational Competencies: A Harmonic Collaboration, International Journal of Advanced Research in Computer Science and Software Engineering 2(1): 45-50.

Davenport, T. H.; Prusak, L. 1998. Working Knowledge: How Organizations Manage What They Know. Boston, Mass.: Harvard Business School Press. 199 p.

Davidavičienè, V.; Raudeliūnienè, J. 2010. ICT in tacit knowledge preservation, in The 6th International Conference "Business and Management 2010" Ed. by R. Ginevičius, A. V. Rutkauskas, R. Počs, May 13-14, 2010, Vilnius, Lithuania. Vilnius: Technika. 2: 822828. DOI: $10.3846 / \mathrm{bm} .2010 .109$.

Davis, G.; Rhodes, R. A. 2000. From Hierarchy to Contracts and Back again. In: M. Keating, J. John Wanna, P. Weller (eds.). Institutions on the Edge. Melbourne: Allen and Unwin. 74-98.

Dhanaraj, A.; Parkhle, C. 2006. Orchestrating innovation networks, Academy of management review 31(3): 659-669.

Dhanaraj, C.; Lyles, R. A.; Steensma, H. K.; Tihanyi, L. 2004. Managing tacit and explicit knowledge transfer in IJVs: The role of relational embeddedness and the impact on performance, Journal of International Business Studies 35: 428-442.

Dyer, J. H.; Nobeoka, K. 2000. Creating and managing a high-performance knowledge sharing network: The Toyota case, Strategic Management Journal 21: 345-367.

Dyllick, T.; Hockerts, K. 2002. Beyond the business case for corporate sustainability, Business Strategy and the Environment 11: 130-141.

Doyle, B. J.; Asiala, C. M.; Fernández, D. M. 2017. Relative Importance and Knowledge Distribution of Medicinal Plants in a Kichwa Community in the Ecuadorian Amazon, Ethnobiology Letters, 8(1): 1-14.

DOLETA. Prieiga per internetą: http://www.careeronestop.org/CompetencyModel/. 
Drucker P. 1980. Managing in Turbulent Times. New York: Harper \& Row. 239 p.

Drucker, P. 1993. Post-Capitalist Society. New York: Harper Business. 234 p

Drucker, P.; Peter, F. 1969. The Age of Discontinuity. Guidelines to Our Changing Society. New York: Harper \& Row. 54 p.

Dubina, I. N.; Carayannis, E. G.; Campbell, D. F. J. 2012. Creativity Economy and a Crisis of the Economy? Coevolution of Knowledge, Innovation, and Creativity, and of the Knowledge Economy and Knowledge Society, Journal of the Knowledge Economy 3(1): 1-24.

Dubois, D. D. 1993. Competency-based performance improvement: a strategy for organizational change. Amherst: HRD Press Inc. 348 p.

Eikenberry, K. 2007. Remarkable Leadership: Unleashing Your Leadership Potential One Skill at a Time. United States: John Wiley And Sons Ltd. 288 p.

Eulgem, S. 1998. Die Nutzung des unternehmensinternen Wissens. Ein Beitrag aus der perspektive der Wirtschaftsinformatik. Frankfurt am Main. 241 p.

European Evaluation Network for Rural Development. 2010. Working Paper on the Evaluation of National Rural Network Programs. Prieiga per internetą: http://ec.europa.eu/agriculture/rurdev/eval/wp-networks_en.pdf.

EUROSTAT. 2017a. Annual data on employment in knowledge-intensive activities at the national level, by sex (from 2008 onwards, NACE Rev. 2). Prieiga per internetą: http://appsso.eurostat.ec.europa.eu/nui/show.do?dataset=htec_kia_emp2\&lang=en.

EUROSTAT. 2017b. Employment in technology and knowledge-intensive sectors at the national level, by level of education (from 2008 onwards, NACE Rev. 2). Prieiga per internetą: http://appsso.eurostat.ec.europa.eu/nui/show.do?dataset=htec_emp _nisced2\&lang=en.

Evans, P. 1996. Government action, social capital and development: reviewing the evidence on synergy, World Development 24 (6), 1119-1132.

Евланов, Л. Г.; Кутузов, В. А. 1978. Экспертные оценки в управлении. Москва: Экономика. 133 с.

Fink, K. 2005. Knowledge Measurement and Interviewer Bias, Proceedings of I-KNOW '05 Graz, Austria, June 29 - July 1, 2005: 79-86.

Fombelle, P. W.; Jarvis, C. B.; Ward, J.; Ostrom, L. 2011. Leveraging customers' multiple identities: identity synergy as a driver of organizational identification, Journal of Academy of Marketing Science 39: 481-483. DOI: 10.1007/s11747-011-0259-0.

Ghorabaee, M.; Amiri, M.; Sadaghiani, J. S.; Goodarzi, G. 2014. Multiple criteria group decision-making for supplier selection based on copras method with interval type-2 fuzzy sets, The International Journal of Advanced Manufacturing Technology 75: 1115-1130. 
Ginevičius, R. 2006. Daugiakriterinio vertinimo rodiklių svorių nustatymas, remiantis jų tarpusavio sąveika, Verslas: teorija ir praktika 7(1): 3-13.

Ginevičius, R.; Krivka, A. 2009. Konkurencinès aplinkos oligopolinejje rinkoje daugiakriterinis vertinimas, Verslas: teorija ir praktika 10 (4): 247-258.

Ginevičius, R.; Podvezko, V. 2007. Some problems of evaluating multicriteria decision methods, International Journal of Management and Decision Making 8(5): 527-539. DOI: 10.1504/IJMDM.2007.013415.

Girdauskienè, L. 2012. Kürybinès organizacijos vadybos sistemos ịveiklinimas žiniu aspektu. Daktaro disertacija.

Girdauskienè, L.; Savanevičienè, A. 2010. Žinių valdymo ypatumai kūrybinèje organizacijoje, Ekonomika ir vadyba 15: 491-497.

Girnienè, I. 2014. Žinių valdymo įtaka nuolatiniam inovacijų kūrimui: atvejo analizè, Informacijos mokslai 68: 44-62.

Girotra, K.; Netessine, S. 2013. Business model innovation for sustainability, Faculty and Research Working Paper 5: 70-83.

Gold, A.; Malhotra, A.; Segars, A. 2001. Knowledge management: an organizational capabilities perspective, Journal of Management Information Systems 18(1): 185-214.

Gonzalez, D. R. V.; Martins, M. F. 2014. Knowledge Management: an Analysis From the Organizational Development, Journal of technology management \& innovation 9(1): 131147. DOI: https://dx.doi.org/10.4067/S0718-27242014000100011.

Graičiūnas, V. A. 1937. Relationship in Organization. L.H.Gulick, L.F.Urwic (Eds.) Papers on the Science of Administration, N.Y.: I.P.A.

Green, P. 1999. Building Robust Competencies. Linking Human Resource Systems to Organizational Strategies. San Francisco: Jossey-Bass. 213 p.

Gudauskas, R. 2000. Informacinès visuomenès kūrimo strategija: Lietuva globalių permainų kontekste, Informacijos mokslai 14: 9-17.

Gudauskas, R.; Ramanauskienė, S. 2004. Strateginė vadyba žinių ekonomikoje: žinių auditas, Informacijos mokslai. 29: 46-57.

Guitouni, A; Martel, J. M. 1998. Tentative guidelines to help choosing an appropriate MCDA method, European Journal of Operational Research 109: 501-521.

Ha, S. H.; Krishnan, R. 2008. A hybrid approach to supplier selection for the maintenance of a competitive supply chain, Expert Systems with Applications 34(2): 1303-1311.

Hagedoorn, J.; Duysters, G. 2002. The effect of mergers and acquisitions on the technological performance of companies in a high-tech environment, Technology Analysis and Strategic Management 14: 67-89.

Hakeem, B. 2007. Leadership Through Creativity \& Synergy 2+2=5. Journal of Managerial Sciences 1(2): 75-86. 
Haken, H. 1977. Synergetics. A Workshop. Proceedings of the International Workshop on Synergetics at Schloß Elmau, Bavaria: Springer Verlag. 282 pp.

Hall, H. 2001. Input-friendliness: Motivating knowledge sharing across intranets, Journal of Information Science, 27: 139-146.

Hamil, D. 1998. Project Teams that Work. GISdevelopment.net, Gita, People Issues. 44 p.

Harrigan, K. R.; Di Guardo, M. C.; Cowgill, B. 2017. Multiplicative-innovation synergies: tests in technological acquisitions, The Journal of Technology Transfer 42(5): 1212-1233.

Hau Y. S.; Kim, B.; Lee H.; Kim Y.G. 2013. The effects of individual motivations and social capital on employees' tacit and explicit knowledge sharing intentions, International Journal of Information Management 33: 356-366.

Hemlin, S. 2002. Creative knowledge environments in the innovation systems, MPP Working Paper 7: 1-14.

Hemlin, S.; Allwood, Carl. M.; Martin, B. R. 2008. Creative Knowledge Environments, Creativity Research Journal 20(2):196-210. DOI: 10.1080/10400410802060018.

Holsapple, C.; Jones, K.; Singh, M. 2007. Linking Knowledge to Competitiveness: Knowledge Chain Evidence and Extensions. In Murray E. Jennex editor. Knowledge Management in Modern Organizations. Hershey: Idea Group Publishing. 51-76.

Huang, Y.; Ye, J.; Gao, Z. 2012. Study on Team Stability Based on the Perspective of Knowledge Potential, Journal iBusiness 4: 256-259. Preiga per internetą: http://dx.doi.org/10.4236/ib.2012.43032.

Huang, Q.; Davison, R. M.; Gu, J. 2011. The impact of trust, guanxi orientation and face on the intention of Chinese employees and managers to engage in peer-to-peer tacit and explicit knowledge sharing, Information Systems Journal 21: 557-577.

Hwang, C. L.; Yoon, K. 1981. Multiple Attribute Decision Making Methods and Applications. Berlin: Springer - Verlag.

Yang, C.; Chen, L. 2007. Can organizational knowledge capabilities affect knowledge sharing behavior?, Journal of Information Science 33(1): 95-109.

Ibarra, H.; Kilduff, M.; Tsai, W. 2005. Zooming in and out: connecting individuals and collectivities at the frontiers of organizational network research, Organization science 16(4): 359-371.

Ying, L.J.; Pheng, L.S. 2009. Developing an organizational learning-based model for risk management in Chinese construction firms: a research agenda, International Journal 18(2): 170-186.

Ishikawa, A.; Nakagawa, J. 2013. An Introduction to Knowledge Information Strategy: From Business Intelligence to Knowledge Sciences. Singapore: World Scientific Publishing Co. Pte. Ltd. 
Jacobsen, A.; Prusak, L. 2006. The cost of knowledge, Harvard Business Review 84(11): 34 .

Jahnke, M., 2013. Meaning in the Making: Introducing a Hermeneutic Perspective on the Contribution of Design Practice to Innovation. Doctoral Dissertation. HDK - School of Design and Crafts, University of Gothenburg.

Jakubavičius, A.; Jucevičius, R.; Jucevičius, G.; Kriaučionienė, M.; Keršys, M. 2008. Inovacijos versle: procesai, parama, tinklaveika. VŠi Lietuvos inovacijų centras. Prieiga per internetą: http://e-stud.vgtu.lt/users/files/dest/10502/inovacijos_versle.pdf.

Johnson, S. 2007. Future Perfect: The Case For Progress In A Networked Age. New York: Riverhead books.

Joshi, A. 2006. The Influence of organizational demography on the external networking behavior of teams, Academy of management review 31(3): 583-595.

Jurevičienè, D.; Komarova, A. 2010. Darbuotojo konkurencingumo vertinimo teoriniai aspektai, Verslas: Teorija ir praktika 11(2): 124-133.

Kankanhalli, A.; Tan, B. C. Y.; Wei, K. K. 2005. Contributing knowledge to electronic knowledge repositories: An empirical investigation, MIS Quarterly 29: 113-143.

Kapatyla, J.; Kujansivu P.; Lonnqvist, A. 2012. National intellectual capital performance: a strategic approach, Journal of Intellectual Capital 13(3): 343-362.

Kaplow, R.; Hardin, S. R. 2007. Critcal care nursing: Synergy for optimal outcames. Sudbury, MA: Jones \& Bartlett.

Karazijienė, Ž.; Sabonienė, A. 2010. Žinių visuomenės formavimas žinių ekonomikos kontekste, Ekonomika ir vadyba 15: 566-574.

Katinienė, A.; Skačkauskienè, I. 2014. Socialinio kapitalo vadybiniai aspektai, Mokslas Lietuvos ateitis 6(1): 25-32.

Katz, R., A.; Page, A. 2013. Sustainable business, Emory Law journal 1: 851-883.

Keast, R.; Mandell, M.; Brown, K.; Wollcock, G. 2004. Network Structures: Working Differently and Changing Expectations, Public Administration Review 64(3): 363-371.

Kebede, G. 2010. Knowledge management: an information science perspective, International Journal of Information Management 30: 416-424.

Kendall, M. G. 1970. Rank Correlation Methods. 4th ed. London: Griffin.

Keshavarz Ghorabaee, M.; Zavadskas, E. K.; Olfat, L.; Turskis, Z. 2015. Multi-criteria inventory classification using a new method of evaluation based on distance from average solution (edas), Informatica 26(3): 435-451.

Ketchen, D. J.; Hult, G. T. M. 2011. Marketing and organization theory: opportunities for synergy, Journal of the Academy of Marketing Science 39: 481-483. DOI: $10.1007 / \mathrm{s} 11747-011-0259-0$ 
Khan, I. A. 2010. Knowledge Groups: A Model for Creating Synergy Across the Public Sector, Public Organization Review 10: 139-152. DOI: 10.1007/s11115-009-0101-z

King, W. R.; Chung, T. R.; Haney, W. H. 2008. Knowledge management and organizational learning, International Journal of Management Science 36(2): 167-172.

Kirchhoff, C., J.; Lemos, M., C.; Kalafatis, S. 2015. Creating synergy with boundary chains: Can they improve usability of climate information?, Climate Risk Management 9: 77-85. DOI: http://dx.doi.org/10.1016/j.crm.2015.05.002.

Kizilhan, T.; Bal Kizilhan, S. 2015. The Rise of the Network Society - The Information Age: Economy, Society, and Culture, Contemporary Educational Technology 7(3): 277280. Prieiga per internetą: http://dergipark.gov.tr/cet/issue/25745/271563.

Kothari, A.; Rudman, D.; Dobbins, M.; Rouse, M.; Sibbald, S.; Edwards, N. 2012. The use of tacit and explicit knowledge in public health: a qualitative study, Implementation Science 7(20): 1-12.

Kržin, M.; Širca, N. T.; Babnik, K. 2017. The Importance of Knowledge in the Development of Services, Analysis of Cam Services Development in Sloveniaa. In Management Challenges in a Network Economy: Proceedings of the MakeLearn and TIIM International Conference, 17-19 May 2017, Lublin, Poland. 467-473.

Lamoureux, K. 2008. Competency Management: Gateway to an Integrated Talent Strategy, Bersin \& Associates Research Report 1.0: 7-10.

Landau, C.; Karna, A.; Richter, A.; Uhlenbruck, K. 2016. Institutional leverage capability: Creating and using institutional advantages for internalization, Global strategy journal 6(1): 50-68.

Lasker, R. D.; Weiss, E. S.; Miller, R. 2001. Partnership synergy, The Mildbank Quarterly, 79(2): 179-205.

Laužackas, R. 1997. Svarbiausios profesinès edukologijos squvokos. Kaunas: VDU leidykla. Laužackas, R. 2005. Profesinio rengimo metodologija. Monografija. Kaunas: VDU leidykla. Laužackas, R.; Stasiūnaitè, E.; Teresevičienè, M. 2005. Kompetencijų vertinimas neformaliajame ir savaiminiame mokymesi. Monografija, Kaunas: VDU leidykla. 224 p.

Law, M. M. S.; Hills, P.; Hau, B. C. H. 2017. Engaging Employees in Sustainable Development - a Case Study of Environmental Education and Awareness Training in Hong Kong, Business Strategy and the Environment 26: 84-97. doi: 10.1002/bse.1903.

Lawford, G. R. 2003. Beyond success: Achieving synergy in teamwork, The Journal for Quality and Participation 26(3): 23-27.

Li, H.; Adeli, H.; Sun, J.; Han, J. G. 2011. Hybridizing principles of TOPSIS with casebased reasoning for business failure prediction, Computers \& Operations Research 38: 409-419. 
Liang, G. S. 1999. Fuzzy MCDM based on ideal and anti-ideal concepts, European Journal of Operational Research 112(3): 682-691.

Lietuvos kvalifikacijų sandara. 2012. Kvalifikacijų ir profesinio mokymo plètros centras, Vilnius. Prieiga per internetą: http://www.kpmpc.lt/kpmpc/wp-content/uploads /2015/11/LTKS-EKS-knyga-2012.pdf.

Lyly, E. R. 2012. Learning organization [al] learning, International Journal of Business and Social Science 3(6): 217-221.

Lin, H. F. 2007. Effects of extrinsic and intrinsic motivation on employee knowledge sharing intentions, Journal of Information Science 33: 135-149.

Lin, Y. H.; Lee, P. C.; Chang, T. P.; Ting, H. I. 2008. Multi-attribute group decision making model under the condition of uncertain information, Automation in Construction 17(6): 792-797.

Liu, H. C.; Mao, L. X.; Zhang, Z.Y.; Li, P. 2013. Induced aggregation operators in the VIKOR method and its application in material selection, Applied Mathematical Modelling 37: 6325-6338.

Lukoševičius, R. 2005. Intelekto išteklių vadyba žinių ekonomikoje, Informacijos mokslai 33: 34-39.

Lupo, T. 2015. Fuzzy ServPerf model combined with ELECTRE III to comparatively evaluate service quality of international airports in Sicily, Journal of Air Transport Management 42: 249-259.

MacCrimmon, K. R. 1968. Decision making among multiple attribute alternatives: A survey and consolidated approach. RAND Memorandum, RM-4823-ARPA. The RAND Corporation, Santa Monica, Calif.

Maier, R.; Harich, T.; Peinl, R. 2009. Enterprise Knowledge Infrastructures. Berlin: Springer.

Mardani, A.; Jusoh, A.; MD Nor, K.; Khalifah, Z.; Zakwan, N.; Valipour, A. 2015. Multiple criteria decision-making techniques and their applications - a review of the literature from 2000 to 2014, Economic Research-Ekonomska Istraživanja 28(1): 516571, DOI: 10.1080/1331677X.2015.1075139.

Martin, R. 2012. Measuring Knowledge Bases in Swedish Regions, European Planning Studies 20(9):1569-1582, DOI: 10.1080/09654313.2012.708022.

Martinkus, B.; Neverauskas, B.; Sakalas, A. 2002. Vadyba: specialistu rengimo kiekybinis ir kokybinis aspektas. Kaunas.

Matošková, J. 2016. Measuring Knowledge, Journal of Competitiveness 8(4): 5-29. DOI: $10.7441 /$ joc.2016.04.01.

Mažeikienė, L. Informacijos apie ES valdymas ir sklaida Lietuvoje. Prieiga per internetą: http://vddb.library.lt/fedora/get/LT-eLABa-0001:E.02 2009 D_20090804_13275920963/DS.005.0.01.ETD. 
McClelland, D. C. 1973. Testing for competence rather than intelligence, American Psychologist 1: 1-14.

Melnikas, B. 2008. The Knowledge-based Economy in the European Union: Innovations, Networking and Transformation Strategies, Transformations in Business \& Economics 7(15): 170-192.

Melnikas, B. 2010. Creating knowledge-based society and knowledge economy: the main principles and phenomena, Ekonomika 89(2): 55-74. ISSN 1392-1258.

Melnikas, B.; Jakubavičius, A.; Strazdas, R.; Chlivickas, E.; Lobanova L.; Stankevičienė, J. 2014. Intelektinis verslas. Vilnius: Technika.

Melnikienè, R.; Vidickienè, D. 2006. Žinių vadyba kaip priemonè tobulinti Lietuvos žemès ūkio kooperacijos politiką, Vadybos mokslas ir studijos - kaimo verslu ir ju infrastruktūros plètrai: straipsnių rinkinys. Akademija: LŽŪU Leidybos centras.

Millar, C. C. J. M.; Chen, S.; Waller L. 2017. Leadership, knowledge and people in knowledge-intensive organisations: implications for HRM theory and practice, The International Journal of Human Resource Management 28(2): 261-275. DOI: $10.1080 / 09585192.2016 .1244919$

Miller, C.R.; Richard, B.; Arora, S. 2011. Alternate signs of life: the growth of biotechnology industries in Shanghai and Bangalore, Technological Forecasting and Social Change 78(4): 565-574.

Mintzberg, H. 1989. Mintzberg on management: Inside our strange world of organizations. Simon and Schuster.

Mir, M. A.; Ghazvinei, P. T.; Sulaiman, N. M. N.; Basri, N. E. A.; Saheri, S.; Mahmood, N. Z.; Jahan, A.; Begum, R. A.; Aghamohammadi, N. 2016. Application of TOPSIS and VIKOR improved versions in a multi criteria decision analysis to develop an optimized municipal solid waste management model, Journal of Environmental Management 166: 109-115. DOI: https://doi.org/10.1016/j.jenvman.2015.09.028.

Moradmand, N.; Datta, A.; Oakley, G. 2014. An Interactive Multimedia Development Life Cycle Model Based on a Cognitive Theory of Multimedia Learning. In J. Viteli \& M. Leikomaa (Eds.), Proceedings of EdMedia: World Conference on Educational Media and Technology 23 Jun 2014: 746-761. Association for the Advancement of Computing in Education (AACE). ISBN 9781939797087.

Morkvènas, R. 2010. Organizacijos žiniu potencialo vertinimas. Daktaro disertacija. Vilnius: Technika.

Naim, S.; Hagras, H. 2014. A type-2 hesitation fuzzy logic based multi-criteria group decision making system for intelligent shared environments, Soft Computing 18: 13051319.

Neef, D.; Siesfeld, T.; Cofela, J. 1998. The Economic Impact of Knowledge. Boston: Butterworth-Heinemann. 384 p. 
Newman, M.; Barabási, A.; Duncan, J. W. 2006. The Structure and Dynamics of Networks. New York: Princeton.

Nonaka, I. 1994. A Dynamic Theory of Organizational Knowledge Creation, Organizational Science 5(1): 14-37.

Nonaka, I.; Takeuchi H. 1995. The Knowledge-creating Company. Oxford University Press. ISBN 0195092694

Nonaka, I.; Toyama, R.; Nagata, A. 2000. A Firm as a Knowledge creating Entity: A New Perspective on the Theory of the firm, Industrial and corporate change 9(1): 419-436.

Oluic-Vukovic, V. 2001. From information to knowledge: some reflections on the origin of the current shifting towards knowledge processing and further perspective, Journal of the American Society for Information Science and Technology 52: 54-61.

Onions, P. E. W. 2010. Umbrellas, alphabet soup and knowledge management theory. In 11th European Conference on Knowledge Management, ECKM 2010, Famalicão, Portugal, 2-3 September.

Opricovic, S.; Tzeng, G. H. 2002. Multicriteria planning of post-earthquake sustainable reconstruction, Computer-Aided Civil and Infrastructure Engineering 17(3): 211-220.

Opricovic, S.; Tzeng, G. H. 2004. Compromise solution by MCDM methods: A comparative analysis of VIKOR and TOPSIS, European Journal of Operational Research 156(2): 44-455.

Osterloh, M.; Frey, B.S. 2000. Motivation, knowledge transfer, and organizational forms, Organization Science 11: 538-550.

Osterwalder, A. 2004. The business model ontology: A proposition in a design science approach. Doctoral Disertation.

Owen-Smith, J.; Powell, W. 2008. Networks and Institutions. In: R. Greenwood et al. (eds.). The Handbook of Organizational Institutionalism. New York: Sage. 596-624.

Oztaysi, B. 2014. A decision model for information technology selection using AHP integrated TOPSIS-Grey: The case of content management systems, Knowledge-Based Systems 70: 44-54.

Pandey, S. C.; Dutta, A. 2013. Role of knowledge infrastructure capabilities in knowledge management, Journal of knowledge management 17(3): 435-453. DOI: 10.1108/JKM-112012-0365.

Park, M.; Lee, H. S.; Kwon, S. 2010. Construction knowledge evaluation using expert index, Journal of Civil Engineering and Management 16(3): 401-411.

Patton, C. V.; Sawicki, D. S.; Clark, J. J. 2012. Basic Methods of Policy Analysis and Planning. New York: Routledge. 3rd Edition.

Patton, M. Q. 1990. Qualitative evaluation and research methods. SAGE Publications, inc. 
Phelps, C.; Heidl, R.; Wadhwa, A. 2012. Knowledge, Networks, and Knowledge Networks A Review and Research Agenda, Journal of Management 38(4): 1115-1166.

Pina, K.; Tether, B. S. 2016. Towards understanding variety in knowledge intensive business services by distinguishing their knowledge bases, Research Policy 45(2): 401413.

Podolny, M. J.; Page, K. L. 1998. Network Forms of Organization, Annual Reviews of Sociology 24: 57-76.

Podvezko, V. 2008. Sudėtingų dydžių kompleksinis vertinimas, Verslas: teorija ir praktika 9(3): 160-168.

Podvezko, V. 2011. The Comparative Analysis of MCDA Methods SAW and COPRAS, Inzinerine Ekonomika-Engineering Economics 22(2): 134-146.

Podvezko, V. 2012. Dominuojančiųjų alternatyvų daugiakriteriniai metodai, Lietuvos matematikos rinkinys. Lietuvos matematiku draugijos darbai 53: 96-101.

Polanyi, M. 1962. Personal knowledge. Chicago, IL.: University of the Chicago Press.

Polanyi, M. 1967. The Tacit Dimension. London: Routledge \& K. Paul.

Popescu, G. H.; Sabie, O.; Comanescu, M. 2016. The Role of Human Capital in the Knowledge-networked Economy, Psychosociological Issues in Human Resource Management 4(1):168-174.

Powell, T., H.; Ambrosini, V. 2017. Espoused versus realized knowledge management tool usage in knowledge intensive organizations, The International Journal of Human Resource Management 28(2): 356-378.

Probst, G.; Raub, S.; Romhardt, K. 2006. Žiniu vadyba: sékmès komponentai. Vilnius: Knygiai.

Proscevičienè, G. 2010. Tinklinio bendradarbiavimo kokybės srityje apibrèžimas, Jaunuju mokslininku darbai 2(27): 45-51.

Radu, L. N.; Constantin, D. L. 2007. Territorial Development and Networking in the European Union and Romania, Journal of Applied Quantitative Methods 2(3): 357-368.

Raudeliūnienè, J.; Račinskaja, I. 2014. Žinių igijimo proceso vertinimas Lietuvos draudimo sektoriuje, Verslas: teorija ir praktika (15): 149-159.

Reagans, R., E.; Zuckerman, E., W. 2001. Networks, diversity and performance: The social capital of R\&D teams, Organization Science 12: 502-518.

Reagans, R.; Zuckerman, E.; McEvily, B. 2004. How to make the team: Social networks vs. demography as criteria for designing effective teams, Administrative Science Quarterly 49: 101-133. 
Reychav, I.; Weisberg, J. 2009. Going beyond technology: Knowledge sharing as a tool for enhancing customer-oriented attitudes, International Journal of Information Management 29: 353-361.

Rententbach, B. 2009. Synergy. USA, Bloomington, Indiana: AuthorHouse.

Ribašauskienè, E.; Šalengaitè, D. 2013. Tinklaveika darnaus kaimo vystymosi kontekste: Lietuvos kaimo tinklo atvejis: Mokslo studija. Vilnius: Lietuvos agrarinès ekonomikos institutas. 59 p. ISBN 9789955481386.

Roy, B. 1968. Classement et choix en présence de points de vue multiples (la méthode ELECTRE). La Revue d'Informatique et de Recherche Opérationelle (RIRO) 2(8): 57-75.

Rossi, P. H.; Lipsey, M. V.; Freeman, H. E. 2004. Evaluation: A Systematic Approach. Sage Publications.

Saaty, T. L. 1980. The Analytic Hierarchy Process. New York: M.Graw-Hill. T.

Saaty, T. L. 1993. Decision-Making. Analytic Hierarchy Process. Moscow: Radio and Communication.

Sakalas, A. 2012. Žinių vadyba: besimokančios ịmonès kūrimas. Kaunas: Technologija.

Salancik, G. 1995. Wanted: a good network theory of organizations, Administrative science quarterly 40(2): 343-348

Salonius, H.; Lonnqvist, A. 2012. Exploring the policy relevance of national intellectual capital information, Journal of Intellectual Capital 13(3): 331-342.

Sarraf, A. Z.; Mohaghar, A.; Bazargani, H. 2012. Developing TOPSIS method using statistical normalization for selecting Knowledge management strategies, Journal of Industrial Engineering and Management 6(4): 860-875. DOI: http://dx.doi.org/10.3926/jiem.573.

Senge, P. M. 2006. The fifth discipline: The art and practice of the learning organization. New York: Doubleday / Currency.

Shannon, V. J. 1998. Partnerships: The Foundation for Future Success, Canadian Journal of Nursing Administration 11: 61-76.

Shatrevich, V.; Ščeulovs, D.; Gaile-Sarkane, E. 2015. Dynamic intellectual capital model in a company, Business, Management and Education 13(1): 76-94.

Shum, B.S.; Cannavacciuolo, L.; Liddo, A.; Iandoli, L.; Quinto, I. 2011. Using social network analysis to support collective decision-making process, International Journal of Decision Support System Technology 3(2): 15-31.

Simanavičienè, R.; Cibulskaite, J. 2015. Sprendimo, gauto topsis metodu, patikimumo statistinè analizè, Lietuvos statistikos darbai 54(1): 110-118.

Simon, H. A. 1947. Administrative Behavior: a Study of Decision-Making Processes in Administrative Organizations. New York: Simon \& Schuster. 
Singh, J.; Fleming, L. 2010. Lone inventors as sources of breakthroughs: Myth or reality?, Management Science 56: 41-56.

Slavinskaitė, N. 2012. Kompleksinis pieno pramonès įmonių pagrindinès veiklos efektyvumo vertinimas, Buhalterinès apskaitos teorija ir praktika 12: 82-94.

Smith, E. A. 2001. The role of tacit and explicit knowledge in the work place, Journal of Knowledge Management 5(4): 311-321.

Smith, I. W. 2004. Continuing Professional Development and Workplace Learning 7: Human Resource Development - a Tool For Achieving Organizational Change, Library Management 25(3): 148-151.

Smith, R. A. 2006. Using the Synergy Model to provide spiritual care in critical care settings, Critical Care Nurse 26(4): 41-47.

Smith, R.; Farquhar, A. 2000. The Road Ahead for Knowledge Management: An AI Perspective, AI Magazine 21(4): 17-40.

Spearman, C. 1904. The proof and measurement of association between two things, The American Journal of Psychology 15(1): 72-101.

Spender, J. C.; Eden, C. 1998. Dynamics of individual and organizational knowledge. Managerial and Organizational Cognition: Theory, Methods and Research. London: Sage.

Staniulienè, S. 2006. Tinklinių struktūrų projektavi mo principai ir metodai, Organizacijų vadyba: sisteminiai tyrimai 40: 147-161.

Stankevičienè, J.; Pilelytė, J. 2015. Investicijų i aukštojo mokslo institucijas valdymas, Mokslas - Lietuvos ateitis 7(2): 141-149.

Stankiewicz, R.,1980. Leadership and the Performance of Research Groups. Doctorial disertation. Research Policy Institute, University of Lund, Lund.

Stanujkic, D. 2013. An extension of the MOORA method for solving fuzzy decision making problems, Technological and Economic Development of Economy 19(1): 228255. DOI: 10.3846/20294913.2013.880083.

Stein, M.; Beer, M.; Kreinovich,V. 2013. Bayesian approach for inconsistent information, Information Sciences 245: 96-111.

Steiner, I. 1972. Group Process and Productivity. Academic Press, New York. 204 p.

Stevens, S. S. 1946. On the Theory of Scales of Measurement, Science 103(2684): 677680 .

Stewart, J.; Leopold, J. 2002. Individual Learning, in Human Resources in Organisations. FT Prentice Hall. 156 p.

Stonkienè, M. 2007. Žinių nuosavybès teisių apsauga verslo organizacijoje, Informacijos mokslai 40: 81-94. 
Strambach, S. 2008. Knowledge-intensive business services (KIBS) as drivers of multilevel knowledge dynamics, International Journal of Services Technology and Management (IJSTM) 10: 152-174.

Strassmann, P. 1998. The Value of Knowledge Capital, American Programmer 11(3): 310 .

Strohhecker, J.; Grobler. A. 2012. Implementing sustainable business strategies, Systems research and behavioral science 29: 547-570.

Stuchly, V.; Jasiulewicz-Kaczmarek, M. 2014. Maintenance in sustainable manufacturing, Scientific Journal of Logistics 3: 273-284.

Stufflebeam, D. L. 2007. An Evaluation of Evaluation Approaches and Models. In: Stufflebeam, L. D., Shinkfield, A. J. Evaluation Theory, Models, and Applications. 131234.

Sveiby, E. 1997. The New Organizational Wealth. San Francisco: Berrett-Koehler Publishers. 275 p.

Šćepanović, M.; Barić, K.; Ostojić, Z.; Pintar, A. 2016. The importance of knowledge of the biological and ecological characteristics of wild millet in an integrated weed management. In 60. seminar biljne zaštite. 45-46.

Šimanskienė, L., Paužuolienė, J., Paužuolis, V. 2015. Inovatyvios organizacinès kultūros bruožai smulkaus ir vidutinio verslo įmonèse, Organizacijų vadyba: sisteminiai tyrimai 73: $63-81$.

Titler, M. G. 2004. Methods in translation science, Worldviews Evid Based Nurs 1(1): 3848

Toffler, A. 1980. The Third Wave: The Classic Study of Tomorrow. Bantam Books. 560 p.

Trusculescu, A.; Draghici, A.; Ivascu, V. L. 2016. Importance of Knowledge Management Systems in Online Retail Compared to Traditional Retail. In Managing Innovation and Diversity in Knowledge Society Through Turbulent Time: Proceedings of the MakeLearn and TIIM Joint International Conference 2016. 1091-1099. ToKnowPress.

Tu, Z. Z.; Gu, X.; Ye, Y. J. 2017. Synergy evaluation of industry-university-research institute synergetic innovation system based on knowledge creation, Journal of Discrete Mathematical Sciences and Cryptography 20(1):361-376. DOI: $10.1080 / 09720529.2016 .1183312$.

Tūtlys, V.; Kaminskienè, L.; Pileičikas, G. 2015 Kompetenciju vertinimo užduočiu sudarymo metodika. Kvalifikacijų ir profesinio mokymo plètros centras. Prieiga per internetą: http://www.kpmpc.lt/kpmpc/wp-content/uploads/akreditacija/Kompetencij u_vertinimo_uzduociu_sudarymo_metodika.pdf.

Ulrich, D. 1998. Das neue personalwesen: Mitgestalter der Unternehmenszukunft, Harvard Busines Manager 56(4): 59-69. 
Ulubeyli, S.; Kazaz, A. 2009. A multiple criteria decision-making approach to the selection of concrete pumps, Journal of Civil Engineering and Management 15(4): 369376.

Urban, B.; Joubert, G. C. D. S. 2017. Multidimensional and comparative study on intellectual capital and organisational performance, Journal of Business Economics and Management 18(1): 84-99. DOI: 10.3846/16111699.2016.1255990.

Urwick, L. 1943. Personnel Management in Relation to Factory Organization. L. Urwick Institute of Labour Management, London. 27 p.

Ustinovichius, L.; Zavadskas, E. K.; Podvezko, V. 2007. Application of a quantitative multiple criteria decision making (MCDM-1) approach to the analysis of investment in construction, Control and Cybernetics 36(1): 251-268.

Valentim, L.; Lisboa, J. V.; Franco, M. 2015. Knowledge Management Practices and Absorptive Capacity in Small and Medium-sized Enterprises: Is There Really a Linkage?, R\&D Management 46(4): 711-725.

Vanagas, R.; Tumėnas, A. 2008. Savivaldybès darbuotojų tarnybinès veiklos vertinimas veiklos valdymo kontekste, Viešoji politika ir administravimas 25: 57-67.

Verganti, R.; Öberg, Å. 2013. Interpreting and envisioning - a hermeneuticframework to look at radical innovation of meanings, Industrial Marketing Management 42: 86-95.

Vidickienè, D. 2008. Leader metodo igyvendinimo Lietuvoje optimizavimas. Vilnius: Lietuvos agrarinès ekonomikos institutas.

Vinogradova, I. 2015. Nuotoliniu kursu parinkimo optimizavimas. Daktaro disertacija.

Voehl, F.; Harrington, J. H. 2006. Knowledge management excellence: the art of excelling in knowledge management. Paton Press, CA.

Von Krogh, G.; Roos, J. 1994. An Essay on corporate epistemology, Strategic Management Journal 15: 53-71.

Vveinhardt, J. 2012. Laisva valia grịstų asmeninių žinių integracijos ị organizacijos žinias kliūčių įveikimo modelis, Profesinès studijos: teorija ir praktika 10: 122-132.

Wallace, T. 2004. Innovation and hybridization: managing the introduction of lean production into Volvo do Brazil, International Journal of Operations and Production Management 24(8): 801-819.

Wasko, M. M.; Faraj, S. 2005. Why should I share? Examining social capital and knowledge contribution in electronic networks of practices, MIS Quarterly 29: 35-57.

Weinert, F. 2001. Concept of Competence: a Conceptual Clarification. In Defining and Selecting Key Competencies, Journal of the American Society for Information Science 53(12): 1009-1018.

Wiig, K. M. 1999. What Future Knowledge Management Users may Expect, Journal of Knowledge Management 3(2): 155-166. 
Wood, D. 2016. The importance of liberal values within policing: police and crime commissioners, police independence and the spectre of illiberal democracy, Policing and Society: An International Journal of Research and Policy 26(2): 148-164.

Wood, D.; Cockcroft, T.; Tong, S.; Bryant, R. 2017. The importance of context and cognitive agency in developing police knowledge: going beyond the police science discourse, The Police Journal: Theory, Practice and Principles 1: 1-15.

Wringe, C. 2015. Beyond useful knowledge: Developing the subjective self, Journal of Philosophy of Education 49(1): 32-44.

Wu, W.; Choi W.L. 2004. Transaction Cost, Social Capital and Firms' Synergy Creation in Chinese Business Networks: An Integrative Approach, Asia Pacific Journal of Management 21: 325-343.

Zavadskas, E. K.; Turskis, Z. 2010. A new additive ratio assessment (aras) method in multicriteria decision-making, Technological and economic development OF ECO NOM Y Baltic Journal on Sustainability 16(2): 159-172.

Zdunczyk, K.; Blenkinsopp, J. 2007. Do organisational factors support creativity and innovation in Polish firms?, European Journal of Innovation Management 10(1): 25-40.

Zins, C. 2007. Conceptual approaches for defining data, information and knowledge, Journal of the American Society for Information Science and Technology 58(4): 479-493.

Žaptorius, J. 2005. Darbo rinka: darbo užmokesčio tendencijų barometras, Filosofija. Socialogija 9(4): 53-61.

Žukauskienè, V. 2011. Neapibrèžtų aibių teorijos elementų taikymai daugiakriteriuose uždaviniuose, 14-osios Lietuvos jaunuju mokslininku konferencijos „, Mokslas - Lietuvos ateitis" 2011 metu teminès konferencijos straipsniu rinkinys. Prieiga per internetą: http://dspace.vgtu.lt/bitstream/1/727/1/Zukauskiene.pdf. 


\section{Autorès mokslinių publikacijų disertacijos tema sąrašas}

\section{Straipsniai recenzuojamuose mokslo žurnaluose}

Skačkauskienè, I.; Kazlauskienè, E.; Katinienè, A. 2017. Modelling of Knowledge Synergy Evaluation, Montenegrin journal of economics 13(1): 35-49. ISSN 1800-5845. Prieiga per interetą: http://www.mnje.com/sites/mnje. com/files/35-49_-_skackaus kiene_et_al.pdf.

Skačkauskienè, I.; Katinienè, A. 2017. Possibilities to Evaluate Employee Knowledge as a Component of Knowledge Synergy at Organisation, Journal of Management 2 (31): 35-43. ISSN 1648-7974.

Skačkauskienė, I.; Hrušecká, D.; Katinienè, A.; Čepel, M. 2018. Evaluation of Knowledge Synergy Components, E+M Ekonomie a Management 21(1): 144-158. DOI: 10.15240/tul/001/2018-1-010.

Skačkauskienè, I.; Katinienè, A. 2015. Žinių potencialo sampratos formavimasis tinklaveikos visuomenèje, Mokslas - Lietuvos ateitis 7(2): 163-171. ISSN 20292341. 


\section{Straipsniai kituose mokslo leidiniuose}

Katinienè, A. 2017. Problem areas of knowledge in a knowledge organisation. International scientific conference: High technologies. Business. Society (HTBS 2017), 13-16.03.2017, Borovets, Bulgaria: proceedings. "Business. Society": Sofia: Scientific Technical Union of Mechanical Engineering Industry. 2: 243-249. ISSN 2535-0005.

Katinienè, A.; Oželienè, D. 2015. Žinių potencialo sinergijos ir darnios organizacijos sąveika. Ekonomikos vystymasis: procesai ir tendencijos: III-osios tarptautinès mokslinès-praktinès konferencijos, ivykusios Vilniaus kolegijos Ekonomikos fakultete $2015 \mathrm{~m}$. balandžio 29 d., straipsniu rinkinys. 1: 312-332. ISBN 9786094360336.

Katinienè, A. 2016a. Žinių ir ryšių sąsajų analizė tinkluose. Verslas XXI amžiuje / Business in XXI Century. eISSN 2029-7149. Preiga per internetą: http://jmk.vvf.vgtu.lt/index.php/conference/2016/paper/viewFile/437/243.

Katiniene, A. 2016b. The Analysis of Creativity-Friendly Organisational Environment from the Perspective of Knowledge Potential. Case Study on Small Enterprises. The International Business Conference 2016: Searching for Innovative and Creative Business Solutions. 1: 19-36. ISBN: 978-609-436-042-8.

Katinienè Aušra; Stravinskienė Aušra. 2016. Organizacijos aplinkos palankios formuotis žinių sinergijai charakteristikos ir jos analizès metodų pasirinkimas. Aukštuju mokyklu vaidmuo visuomeneje: ǐššukiai, tendencijos ir perspektyvos = Role of Higher Education Institutions in Society: Challenges, Tendencies and Perspectives. 1(5): 100-108. ISSN 2029-9311. 


\section{Summary in English}

\section{Introduction}

\section{Problem formulation}

As information society is transforming to knowledge society, the priorities and needs of users determining the changes in organisation activities are also changing. Not only data and information but also knowledge and its effective management are becoming valuable resources. Various researchers define knowledge in different ways; their works include such terms as "competence," "skills," "talent," and "intellect" as well as offer the usage of the concept of broader meaning - "knowledge potential" - that includes both explicit (education, culture) and tacit (skills, abilities, experience) knowledge suitable for the analysis and evaluation of synergy processes. Such confusion in terminology has aggravated greatly the studies of the field of knowledge. The ever-increasing importance of knowledge, the emerging knowledge synergy, the diversity of knowledge terminology (contradictions) as well as the lack of the method of knowledge synergy evaluation have served as the impetus for exhaustive studies in this sphere.

Following the analysis of literature, it is possible to state that the evaluation of knowledge synergy is scarce in scientific works; often knowledge is evaluated as part of intellectual and human capital (Kapyla et al. 2012, Salonius, Lonnqvist 2012). All knowledge models are orientated towards corporate assessment, accounting, and 
management; therefore, the existing evaluation methods do not allow for thorough knowledge synergy evaluation.

Although both knowledge and knowledge synergy that occurs when employees communicate and share knowledge are becoming a more and more significant resource in contemporary organisations, there have been no instruments developed as to how to evaluate knowledge synergy in order to manage it and use it effectively to improve organisation activities.

\section{Relevance of the thesis}

In this complicated, multifunctional and constantly changing world, a society has to be able to change quickly and be ready for future challenges. In order to achieve this, a systematic approach to knowledge and its interaction processes related to the occurrence of synergy has to be employed. All organisations are forced to look for new ways of business development and all of such ways are, in most cases, linked with the ability of an organisation to create and manage knowledge.

Globalisation and technological processes, the progress of information technologies lead to the formation and growth of knowledge economy as well as determine the ability of a society to create, use and constantly renew knowledge; they create new media for the dissemination of such knowledge and offer the possibilities for the formation of knowledge synergy. The existing complex processes of society development and rapidly changing business conditions make organisations more and more orientated towards the processes of innovative knowledge and sustainability through various networking forms that help integrate knowledge and solve competitiveness, strategy development and implementation, coherence and communication problems. Systematic and purposeful use of knowledge, immediate knowledge sharing, during which knowledge synergy occurs, improve the activities of an organisation and enable the organisation to stand out from other organisations, i. e. competitive edge is created, whereas the knowledge, ideas and skills of the workforce become the driving force of such an organisation.

\section{Research object}

The research object is the evaluation of organisation employee knowledge synergy.

\section{The aim of the thesis}

The aim of the thesis - to develop a set of methods to evaluate knowledge synergy, the application of which would enable quantitative evaluation of organisation employee knowledge synergy and its components, and would prepare the ground for reasonable suggestions concerning the improvement of employee knowledge as well as the management of employee relations. 


\section{Tasks of the thesis}

The following tasks were set to achieve the objective of the thesis:

1. To analyse and evaluate critically the concepts of knowledge, knowledge synergy; to revise the definitions of knowledge and knowledge synergy and to present the problem areas of knowledge management.

2. Having analysed the content of knowledge synergy, to crystallise knowledge synergy components and to present suggestions as to how to evaluate such components;

3. To develop the set of organisation employee knowledge synergy evaluation methods that would integrate the evaluated knowledge synergy components and would lead to objective evaluation of organisation employee knowledge synergy;

4. To prepare the methodology for organisation employee knowledge synergy evaluation that could be applied flexibly in various organisations and to check empirically the applicability of the set of knowledge synergy evaluation methods.

\section{Research methodology}

In the thesis, the analysis of scientific literature was carried out with the help of a descriptive method. The methods of logical analysis and synthesis were applied to analyse the literary sources, methodologies, approaches and results. The definitions of the concepts of knowledge and knowledge synergy were revised by means of critical analysis. A systematic analysis method for research enabled the crystallisation of knowledge synergy components, factors and their constituents, for the mathematical expression of which the graph theory, combinatorics and the Laws of Boolean Algebra were employed. Data normalization methods were applied for the integration of knowledge synergy components. When dealing with the organisation employee knowledge synergy evaluation problems expert evaluation methods were engaged, whereas a mixed method of pairwise comparison and questionnaire survey was used to eliminate subjectivity.

Mathematical modelling and testing methods, expert evaluation methods and multiplecriteria evaluation methods were employed to check the flexibility and reliability of the application of the developed set of methods.

\section{Novelty of the thesis}

1. Having analysed the content of knowledge and knowledge synergy, the modern definition of knowledge enabling the analysis of knowledge synergy was theoretically revised and developed further highlighting the processes of knowledge formation.

2. Following the crystallisation of knowledge synergy composition and systematisation of knowledge synergy evaluation methods, the evaluation methods of organisation employee knowledge synergy components (employee knowledge and employee relations) were justified. 
3. The developed set of organisation employee knowledge synergy evaluation methods enables methodical and comprehensive integration of organisation employee knowledge synergy components into the final estimate.

4. The prepared organisation employee knowledge synergy evaluation methods are applied flexibly in various organisations, whereas an experiment carried out in 3 countries supplements the management literature with empirical insights as to the management possibilities of employee knowledge and employee relations as well as the impact on organisation knowledge synergy.

\section{Practical value of research results}

1. The prepared organisation employee knowledge synergy evaluation methods enable objective evaluation of organisation knowledge synergy and its components; the experimental research conducted in various organisations has proved flexible applicability of this methodology.

2. Having evaluated a component of organisation employee knowledge synergy, i. e. employee relations, and having taken into consideration the evaluation results, the relations among employees and knowledge sharing processes can be improved, knowledge sharing and cooperation incentives can be changed or new ones can be integrated.

3. Having evaluated a component of organisation employee knowledge synergy, i. e. employee knowledge, the strong and weak sides of knowledge management can be identified, which enables the management of an organisation to make justified decisions concerning the management of their employee knowledge and to provide for measures to improve business activities.

\section{Defended statements}

1. When organisation employees share knowledge, knowledge synergy occurs, which enables the improvement of the activities of an organisation and which can be evaluated with the help of the set of quantitative methods.

2. The proposed set of knowledge synergy evaluation methods based on the quantitative estimate of employee knowledge and employee relations enables comprehensive organisation employee knowledge synergy evaluation, whereas the methods of knowledge synergy evaluation can be applied flexibly in various organisations.

3. Following knowledge synergy evaluation, organisations have the possibility to correct, change or integrate new knowledge sharing and cooperation incentives; to achieve better performance results; and to increase their potential.

\section{Approval of the research findings}

Nine scientific articles have been published on the thesis topic: two - in international scientific journal (Skačkauskienè, Kazlauskienè, Katinienė 2017; Skačkauskienė, 
Hrušecká, Katiniené, Čepel 2018) and four - in the material of international conferences (Katinienè 2017; Katinienè, Stravinskienė 2016; Katinienè 2016b; Katinienė, Oželienè 2015). Reports on the studied subjects have been given in seven scientific conferences:

1. International Scientific Conference High technologies. Business. Society. (HTBS 2017), 2017 Borovets, Bulgaria.

2. Republic Scientific - Practice Conference Impact of applied research on the quality of contemporary studies, 2017 Vilnius.

3. International Scientific Conference Role of Higher Education Institutions in Society: Challenges, Tendencies and Perspectives, 2016 Alytus.

4. International Business Conference Searching for Innovative and Creative Business Solutions, 2016, Vilnius.

5. Conference of Young Scientists Science -Future of Lithuanian, 2015-2016, Vilnius.

6. International Scientific - Practice Conference Economic Development: Processes and Tendencies, 2015, Vilnius.

\section{The structure of the thesis}

The dissertation consists of the introduction, four chapters, general conclusions, the list of references, the list of the author's publications, and ten annexes. The thesis consists of 117 pages, without the bibliography and the annexes. There are 34 figures and 44 tables.

\section{Significance of knowledge in modern society and its management issues}

The activities of post-modern organisations are based on knowledge and the success of their management depends on how reasonably their resources - in particular the knowledge on future technologies as well as on the changes in consumer needs, nature, environment and, ultimately, human mentality and cultural processes - are exploited.

Modern understanding of knowledge is associated with the names of such scientists as P. Drucker and F. Peter (1969), D. Bell (1973), A. Toffler (1980), I. Nonaka, H. Takeuchi (1995) and etc. The content of knowledge is broad - it is employed in household use, for learning as well as for the development of professional activities. Knowledge includes various spheres of science, art, culture, technologies, etc.; therefore, the definitions of the concept of knowledge are diverse and are interpreted and understood in different ways. A lot of researchers claim that the basis of knowledge consists of data and information as the knowledge used by an individual needs the data that turns into information and generates a greater value in problem solving as well as shaping, assessing, making and implementing decisions (Raudeliūnienè, Račinskaja 2014). In other words, the term knowledge is closely related both with data and information (see Fig. S1.1).

To summarize the works by various scientists it can be stated that knowledge is the expression of the process of a person's cognition, shaped by personal characteristics and 
the surroundings and enabling the person to act. While researching knowledge synergy it is purposeful to use the presented definition of knowledge thus avoiding the confusion of both terminology and knowledge content.

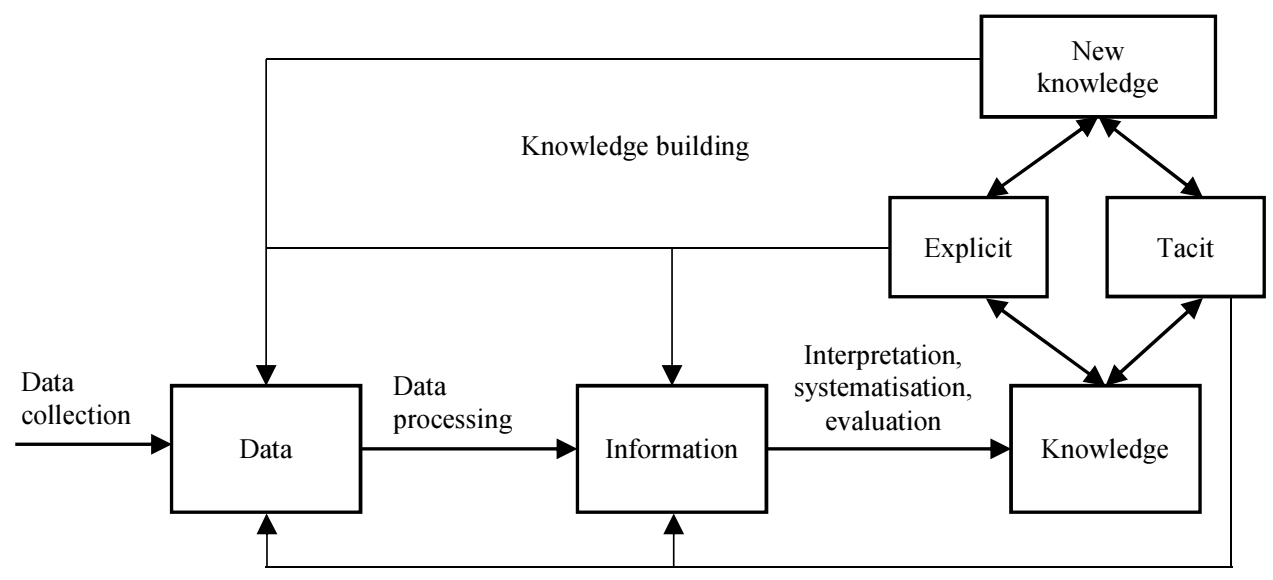

Fig. S1.1. Knowledge formation processes (compiled by the author)

Knowledge synergy can be achieved in the main activities of an organisation, in raising capital, management, marketing, scientific research, transport and logistics, tax optimisation and etc. To summarize the analysis of the definitions of knowledge and synergy it can be stated that knowledge synergy (KS) is the interaction result of explicit and tacit knowledge that has an impact on the activities of an individual or a company and creates new knowledge.

\section{Methodological base for knowledge synergy evaluation}

Synergy processes have been widely analysed in technical sciences, e.g. to describe heat transfer characteristics or to validate laser operation, whereas this phenomenon has not been sufficiently researched on an organisation level (Bivainis, Morkvenas 2008). A lot of researchers (Wei-Ping Wu, Choi 2004, Khan 2010, Ketchen, Hult 2011, Fombelle et al. 2011, Cho et al. 2013, Harrigan et al. 2017) speak of the benefit of synergy and yet only very few resolve to model and calculate it.

I. Steiner (1972) included synergy as one of the components into the calculation of actual productivity formula (Table S2). R. Smith, A. Farquhar (2000) provided the formula for network power applicable for the calculation of knowledge dissemination processes within a network. D. Belohlavek (2007) described the essential characteristics of index components; however, he failed to provide a more thorough analysis as to the evaluation of the singled out components. According to K. Eikenberry (2007), synergy brings benefits that change according to the exponential law. Nevertheless, the application of the latter formula is quite problematic when the difference between the members of an organisation on friendly terms and those on bad terms is big. R. Morkvenas (2010) 
suggested using the following three components for the calculation of synergy: knowledge multiplier, rate of effective communication and average knowledge potential of employees per communication. A more detailed analysis of the components raised certain questions concerning the logical sequence and purpose of the application of these formulas, which only makes calculations more difficult (Table S2.1).

Table S2.1. Synergy evaluation examples (compiled by the author)

\begin{tabular}{|c|c|c|}
\hline Author, year & Formula & Description \\
\hline $\begin{array}{l}\text { I. Steiner } \\
(1972)\end{array}$ & $\begin{array}{l}\overline{\bar{N}}=\overline{\bar{G}}+S-\overline{\bar{T}} \\
\text { Where } \overline{\bar{N}} \text { is actual productivity; } \overline{\bar{G}}- \\
\text { potential productivity; } S-\text { synergy; } \\
\overline{\bar{T}} \text { - faulty group processes. }\end{array}$ & $\begin{array}{l}\text { Synergy is considered as } \\
\text { one of the components of } \\
\text { actual productivity. }\end{array}$ \\
\hline $\begin{array}{l}\text { R. Smith, } \\
\text { A. Farquhar } \\
(2000)\end{array}$ & $\begin{array}{l}\ddot{G}=\ddot{Z}^{\ddot{S}} \\
\text { Where } \ddot{G} \text { is power; } \ddot{Z}-\text { knowledge; } \\
\ddot{S} \text {-dissemination. }\end{array}$ & $\begin{array}{l}\text { The network power formula } \\
\text { is more suitable for the } \\
\text { calculations of knowledge } \\
\text { dissemination processes in a } \\
\text { network. }\end{array}$ \\
\hline $\begin{array}{l}\text { D. Belohlavek } \\
(2007)\end{array}$ & $\begin{array}{l}S=\widehat{G} \cdot \widehat{D} \cdot \widehat{V} \\
\text { Where } S \text { is synergy; } \widehat{G}-\text { individual } \\
\text { abilities; } \widehat{D}-\text { team work; } \widehat{V} \text {-added } \\
\text { value of work. }\end{array}$ & $\begin{array}{l}\text { Organisational synergy } \\
\text { index consists of the } \\
\text { multiplication of three } \\
\text { components. }\end{array}$ \\
\hline $\begin{array}{l}\text { K. Eikenberry } \\
(2007)\end{array}$ & $\begin{array}{l}I_{S}=E^{(f-b)} \\
\text { Where, } I_{S} \text { is personal synergy; } E- \\
\text { person's energy; } f-\text { number of team } \\
\text { members on good terms; } b-\text { number } \\
\text { of team members on bad terms. }\end{array}$ & $\begin{array}{l}\text { The formula based on the } \\
\text { law of exponential growth is } \\
\text { used to calculate personal } \\
\text { synergy. }\end{array}$ \\
\hline $\begin{array}{l}\text { R. Morkvėnas } \\
(2010)\end{array}$ & $\begin{array}{l}P_{s l}=m_{\check{\mathrm{z}}} \cdot r_{e} \cdot p_{v} \\
\text { Where, } P_{s l} \text { is the synergy of } \\
\text { organisation's knowledge potential; } \\
m_{\check{\mathrm{z}}}-\text { knowledge multiplier; } r_{e}-\text { rate } \\
\text { of effective communication; } p_{v}- \\
\text { average knowledge potential of } \\
\text { employees per communication. }\end{array}$ & $\begin{array}{l}\text { The multiplication of three } \\
\text { components is used to } \\
\text { calculate organisational } \\
\text { knowledge potential } \\
\text { synergy. }\end{array}$ \\
\hline
\end{tabular}

M. A. Q. Curley (1998) analysed synergy as one of the most effective resources and presented the synergy model where he singled out the following three levels (based on the expenses): of patients, personnel and an organisation. A. Damodaran (2005) also described a synergy value model. This model was intended for the research of the value of two merged organisations as well as synergies of various types. Similar research was also carried out by K. R. Harrigan et al. (2017). The scientists analysed the impact of 
innovation synergy on the performance of an organisation following the acquisition of technologies. R. Morkvenas (2010) provided the evaluation scheme of organisation knowledge potential synergy, by means of which the quantity of knowledge spread among employees and knowledge multiplier could be calculated. Synergy place and types were also indicated in the IT portfolio selection model offered by W. Cho et al. (2013). However, this model is intended for investment and can be applied for the analysis of possibilities of knowledge investment in an organisation. V. Shatrevich et al. (2015) presented the dynamic intellectual capital model constructed on the basis of the business management model by A. Osterwalder (2004). The dynamic intellectual capital model mentions relational capital; however, it does not reflect knowledge synergy. While analysing the interaction between information systems and quantity management models as well as describing the map of further research, J. Barata, P. R. Cunha (2015) mention the synergy of two types - design time synergy and run time synergy - and indicate their place on the map. Unfortunately, the authors have not presented any more thorough analyses of synergy.

With reference to the presented definition of knowledge synergy, the main components can be singled out, i. e. employee explicit knowledge, employee tacit knowledge, and interrelations (see Fig. S2.1).

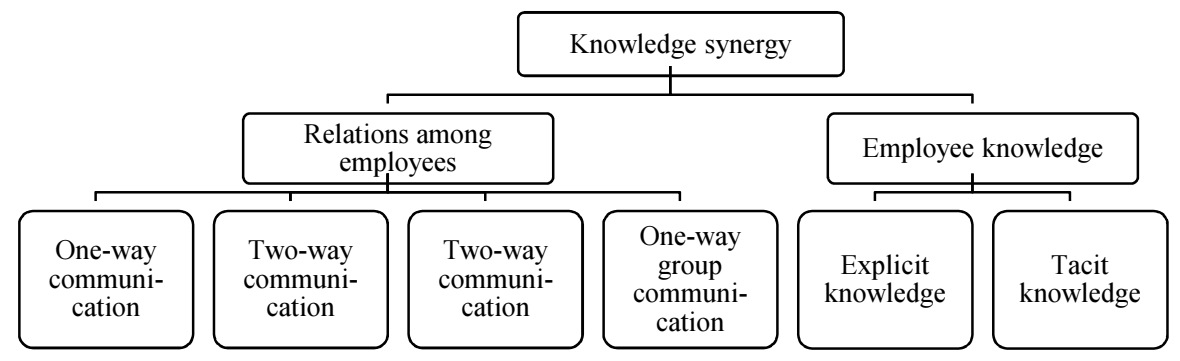

Fig. S2.1. Fundamental scheme of knowledge synergy content (compiled by the author)

By maintaining one-way communication employees share both explicit and tacit knowledge. Also, the same types of knowledge are shared in cases of other types of communication. The types of communication can be expressed through the following set of components: $X=\left\{\mathrm{x}_{1}, \mathrm{x}_{2}, \mathrm{x}_{3}, \mathrm{x}_{4}\right\}$, whereas employee knowledge can be expressed in this way: $Y=\left\{y_{1}, y_{2}\right\}$. The set of components of knowledge synergy factors would be the following: $\left\{\mathrm{x}_{1} \mathrm{y}_{1}, \mathrm{x}_{2} \mathrm{y}_{1}, \mathrm{x}_{3} \mathrm{y}_{1}, \mathrm{x}_{4} \mathrm{y}_{1}, \mathrm{x}_{1} \mathrm{y}_{2}, \mathrm{x}_{2} \mathrm{y}_{2}, \mathrm{x}_{3} \mathrm{y}_{2}, \mathrm{x}_{4} \mathrm{y}_{2}\right\}$. The grouping of the set of synergy components and the performance of arithmetic operations would result in the following:

$$
\begin{aligned}
& \mathrm{X}+\mathrm{Y}=\mathrm{x}_{1} \mathrm{y}_{1}+\mathrm{x}_{2} \mathrm{y}_{1}+\mathrm{x}_{3} \mathrm{y}_{1}+\mathrm{x}_{4} \mathrm{y}_{1}+\mathrm{x}_{1} \mathrm{y}_{2}+\mathrm{x}_{2} \mathrm{y}_{2}+\mathrm{x}_{3} \mathrm{y}_{2}+\mathrm{x}_{4} \mathrm{y}_{2}=\mathrm{y}_{1}\left(\mathrm{x}_{1}+\mathrm{x}_{2}+\right. \\
& \left.\mathrm{x}_{3}+\mathrm{x}_{4}\right)+\mathrm{y}_{2}\left(\mathrm{x}_{1}+\mathrm{x}_{2}+\mathrm{x}_{3}+\mathrm{x}_{4}\right)=\left(\mathrm{y}_{1}+\mathrm{y}_{2}\right)\left(\mathrm{x}_{1}+\mathrm{x}_{2}+\mathrm{x}_{3}+\mathrm{x}_{4}\right) .
\end{aligned}
$$

Having crystallised the components of knowledge synergy and the sets of factors as well as having analysed the methodological basis for the evaluation of knowledge synergy, it can be suggested to apply the following formula for the calculation of knowledge synergy: 


$$
S_{\check{Z}}=R \cdot \hat{Z}
$$

Where $S_{\check{z}}$ is knowledge synergy; $R$ - relations among employees; $\hat{Z}$ - employee knowledge.

With reference to the types of communication as well as the calculation methods of effective communication, a corresponding formula should be applied for a different kind of knowledge synergy (Table S2.2).

Table S2.2. Formulas according to the types of synergy and communication (compiled by the author)

\begin{tabular}{|c|c|c|c|c|}
\hline \multicolumn{5}{|c|}{ Positive simple synergy } \\
\hline $\begin{array}{l}\text { Communi- } \\
\text { cation type }\end{array}$ & \multicolumn{2}{|c|}{$\begin{array}{l}\text { One-way communication (one with } \\
\text { one), } r_{1 \rightarrow 1}\end{array}$} & \multicolumn{2}{|c|}{$\begin{array}{l}\text { Two-way communication (one with } \\
\text { one), } r_{1 \leftrightarrow 1}\end{array}$} \\
\hline Formula & \multicolumn{2}{|c|}{$n$} & \multicolumn{2}{|c|}{$2 n$} \\
\hline \multicolumn{5}{|c|}{ Positive complex synergy } \\
\hline $\begin{array}{l}\text { Communi- } \\
\text { cation type }\end{array}$ & $\begin{array}{l}\text { One-way group } \\
\text { communication } \\
\text { (one with many, } \\
\text { many with one), } \\
r_{1 \rightarrow \infty}\end{array}$ & $\begin{array}{l}\text { One-way group } \\
\text { communication } \\
\text { (many with } \\
\text { many), } r_{\infty \rightarrow \infty}\end{array}$ & $\begin{array}{l}\text { Two-way group } \\
\text { communication } \\
\text { (one with many, } \\
\text { many with one), } \\
r_{1 \leftrightarrow \infty}\end{array}$ & $\begin{array}{l}\text { Two-way group } \\
\text { communication } \\
\text { (many with } \\
\text { many), } r_{\infty \leftrightarrow \infty}\end{array}$ \\
\hline Formula & $\frac{n(n+1)}{2}$ & $\left.2^{n}-1\right)$ & $n(n+1)$ & $2\left(2^{n}-1\right)$ \\
\hline
\end{tabular}

Where: $r$ are relations, $n$ - number of group members.

The final number of relations is calculated according to the following formula S2.3:

$$
R=\frac{d_{\max }}{\sum_{i=1} r_{i}}
$$

Where: $R$ is the final number of relations, $r$ - relations, $i-$ the number of relation types, $d_{\max }-$ the number of organisation employess.

The formula offered for the calculation of the final number of relations enables the elimination of the number of employee relations of large organisations as there is a vast number of relations among employees in a large organisation. Researchers of relations among employees A. Graičiūnas (1937), L. Urwick (1943), H. A. Simon (1947), M. Newman et al. (2006), M. Bianchi (2010) indicated that the number of relations that an employee can establish effectively is limited because if many relations are established, a number of them become ineffective.

\section{Knowledge synergy evaluation methods}

The organisation knowledge synergy evaluation model was developed according to the principles based on the theory of multi-criteria decision analysis (Belton, Stewart 2002). Therefore, having generalised the synergy models and evaluations proposed by various 
authors, the model comprised of two components, i. e. employee knowledge and relations among employees (see Fig. S3.1), was constructed.

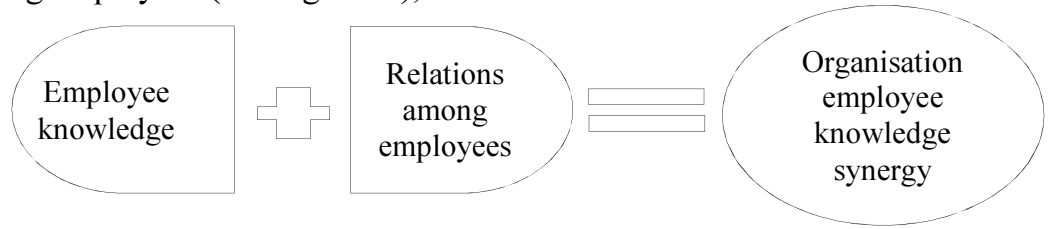

Fig. S3.1. Organisation employee knowledge synergy model (compiled by the author)

In order to evaluate employee knowledge, it is best to divide the factors into two blocks, i. e. explicit and tacit knowledge, and to render significance to these two knowledge blocks, i. e. coefficient of significance of explicit knowledge $(\alpha)$ and of tacit knowledge $(\beta)$. Then, employee knowledge can be calculated according to the following formula S3.1:

$$
\hat{\mathrm{Z}}=\alpha \sum_{n=1} V I_{n}+\beta \sum_{n=1} V N_{n} .
$$

Where $\hat{Z}$ is employee knowledge, $V I_{n}$ - factors of employee explicit knowledge, $V N_{n}-$ factors of employee tacit knowledge, $n$ - number of employees.

The set of the main factors that shape employee knowledge was compiled on the basis of the research conducted by Skačkauskiene et al. (2017), i. e. the factors were identified and grouped into two knowledge blocks (explicit and tacit) according to their type and nature of evaluation (quantitative or qualitative) (Table S3.1).

Table S3.1. Factors that have an impact on employee knowledge (compiled by the author)

\begin{tabular}{|c|c|c|c|c|c|c|c|c|c|c|c|}
\hline \multicolumn{6}{|c|}{ Explicit knowledge (coefficient $-\alpha$ ) } & \multicolumn{6}{|c|}{ Tacit knowledge (coefficient $-\beta$ ) } \\
\hline 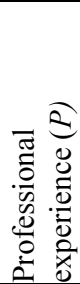 & 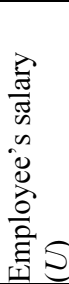 & 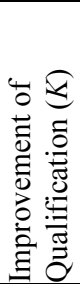 & 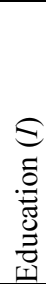 & 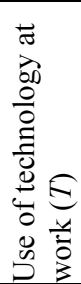 & 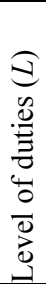 & 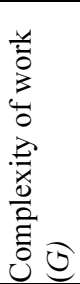 & 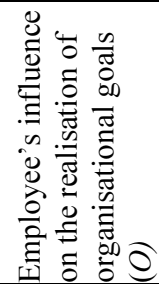 & 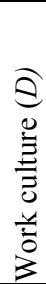 & 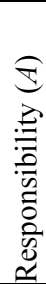 & 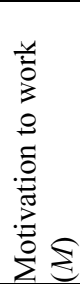 & 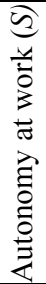 \\
\hline \multicolumn{3}{|c|}{ Quantitative } & \multicolumn{9}{|c|}{ Qualitative } \\
\hline
\end{tabular}

A visualised mathematical expression of organisation employees knowledge synergy evaluation developed through the integration of knowledge synergy components into a summarising estimate according to the formulas S1, S2 and S3 is depicted in Figure S3.2. The formulas from Table $\mathrm{S} 3$ are applied to evaluate the relations among employees.

The calculations of knowledge synergy components enable not only a thorough evaluation of employee knowledge and the relations among employees but also the revelation of the content of organisation employee knowledge synergy. Taking into consideration the results of knowledge synergy evaluation, it is possible to correct the relations among employees, the processes of knowledge sharing as well as to change or integrate new knowledge sharing and cooperation incentives. 


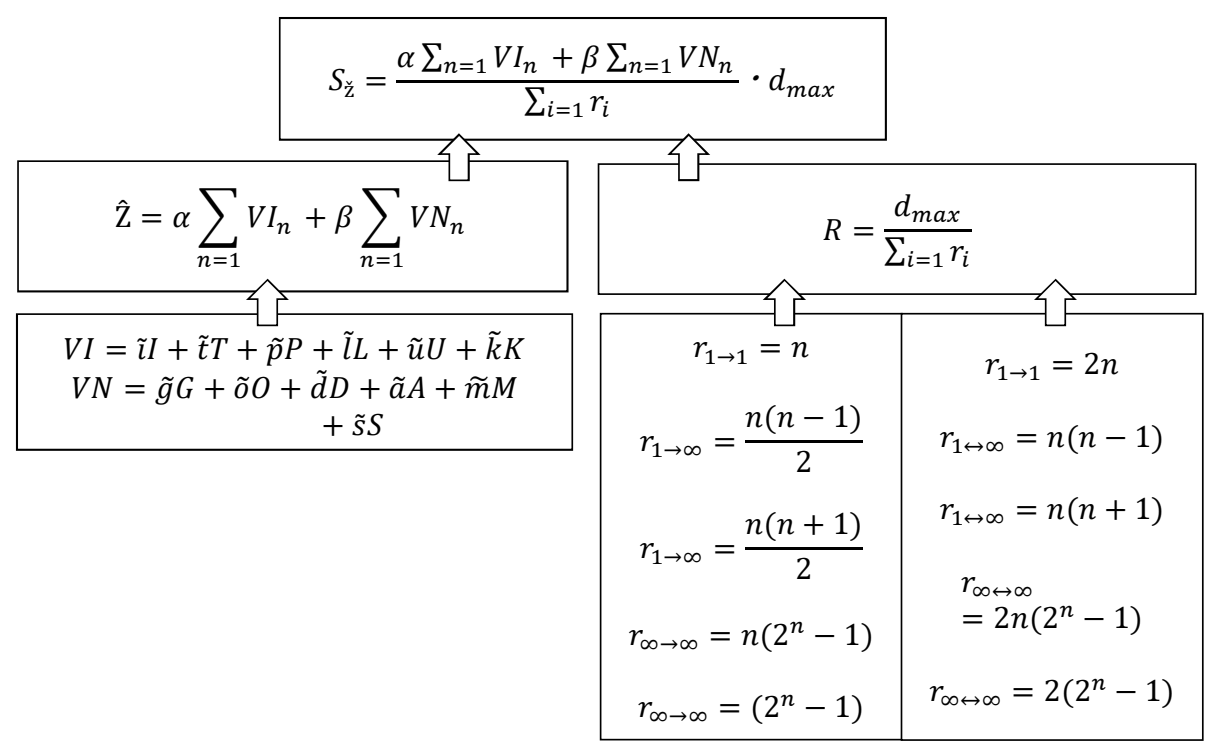

Fig. S3.2. Mathematical expression of knowledge synergy evaluation (compiled by the author)

\section{Empirical research methodology of organisation employee knowledge synergy evaluation methods}

Organisation employee knowledge synergy evaluation consists of the evaluation of the knowledge of employees in an organisation, the evaluation of relations, and the integration of the results of such evaluations in order to determine the final estimate of knowledge synergy.

A systematic approach was applied, i. e. components, factors and constituents were identified, for organisation knowledge synergy evaluation. The analysis of the identified components and knowledge synergy content helps determine the weaknesses and strengths quicker and enables a thorough evaluation of the relations among employees and cooperation, during which the generated knowledge synergy enables the formation of such an organisation, where cooperation among employees and departments enables the achievement of better results compared to the results achieved through individual work.

When evaluating the knowledge of organisation employees, firstly the knowledge factor system is developed, i. e. the factors are selected according to their importance and impact on knowledge. After that, with reference to I. Nonaka and H. Takeuchi (1995), such factors are grouped to explicit and tacit knowledge blocks, whereas SAW and AHP multi-criteria methods are applied to evaluate such factors. Communication is defined as the sphere of immediate relations among people, i. e. a personal and social link with colleagues that occurs through work and the striving for a common goal (Anzenbacher 1992). The types of relations among employees are identified with reference to the definition of communication, whereas the relations are calculated with the help of the rules 
of combinatorics and the graph theory. The estimates of knowledge synergy components are integrated into the final knowledge synergy estimate (Table S4.1).

Table S4.1. Organisation employee knowledge synergy evaluation methodology (compiled by the author)

\begin{tabular}{|c|c|c|}
\hline Steps & Methodologies applied & Methodology stages \\
\hline $\begin{array}{l}\text { Evaluation of employee } \\
\text { knowledge in an } \\
\text { organisation }\end{array}$ & $\begin{array}{l}\text { Methodology to evaluate } \\
\text { employee knowledge in an } \\
\text { organisation }\end{array}$ & $\begin{array}{l}\text { 1. Preparation for evaluation } \\
\text { 2. Consulting } \\
\text { 3. Evaluation } \\
\text { 4. Summary of results }\end{array}$ \\
\hline $\begin{array}{l}\text { Evaluation of relation } \\
\text { types }\end{array}$ & $\begin{array}{l}\text { Methodology to evaluate } \\
\text { types of relations }\end{array}$ & $\begin{array}{l}\text { 1. Identification of relation } \\
\text { types in an organisation } \\
\text { 2. Evaluation of relations }\end{array}$ \\
\hline $\begin{array}{lr}\text { Integration of evaluated } \\
\text { organisation } & \text { employee } \\
\text { knowledge } & \text { synergy } \\
\text { components into a final } \\
\text { organisation } & \text { employee } \\
\text { knowledge } & \text { synergy } \\
\text { estimate } & \end{array}$ & $\begin{array}{l}\text { Methodology to integrate } \\
\text { organisation knowledge } \\
\text { synergy components }\end{array}$ & $\begin{array}{l}\text { 1. Integration of employee } \\
\text { estimates } \\
\text { 2. Integration of relational } \\
\text { estimates } \\
\text { 3. Interpretation of } \\
\text { integrated and final } \\
\text { estimates }\end{array}$ \\
\hline
\end{tabular}

In order to perform the evaluation of employee knowledge in an organisation through the application of multi-criteria evaluation methods, a four-stage algorithm was developed (see Fig. S4.1). The first stage is for preparation, i. e. learning about the management and organisational structure as well as discussing the importance of knowledge research and the need for the expected results. At this stage, it is highly important to prepare the set consisting of a group of experts selected according to certain criteria and factors. The second stage is for consulting, i. e. interviews with the group of experts and employees. At this stage, it is necessary to provide the definitions of the key concepts and to discuss the peculiarities of ongoing research. During the third stage, the surveys of the experts and employees are conducted and the data from the information system of an organisation (IS) is collected. The compatibility of data matrices and expert opinions is calculated. If the opinions are incompatible, the study returns to the second stage. If the opinions are compatible, the study proceeds to the interpretation of results. During the fourth stage, the data is processed and the organisation is presented with the evaluation results, on the basis of which the management can make decisions related to the efficiency of the performance of its employees, e. g. to correct or change goals, set new tasks related to the improvement of the qualification of its employees, career change, and the consolidation of the strengths as well as elimination of the weaknesses of the organisation itself. Such changes in an organisation would lead to more efficient work of employees and improved communication and cooperation within the organisation. 


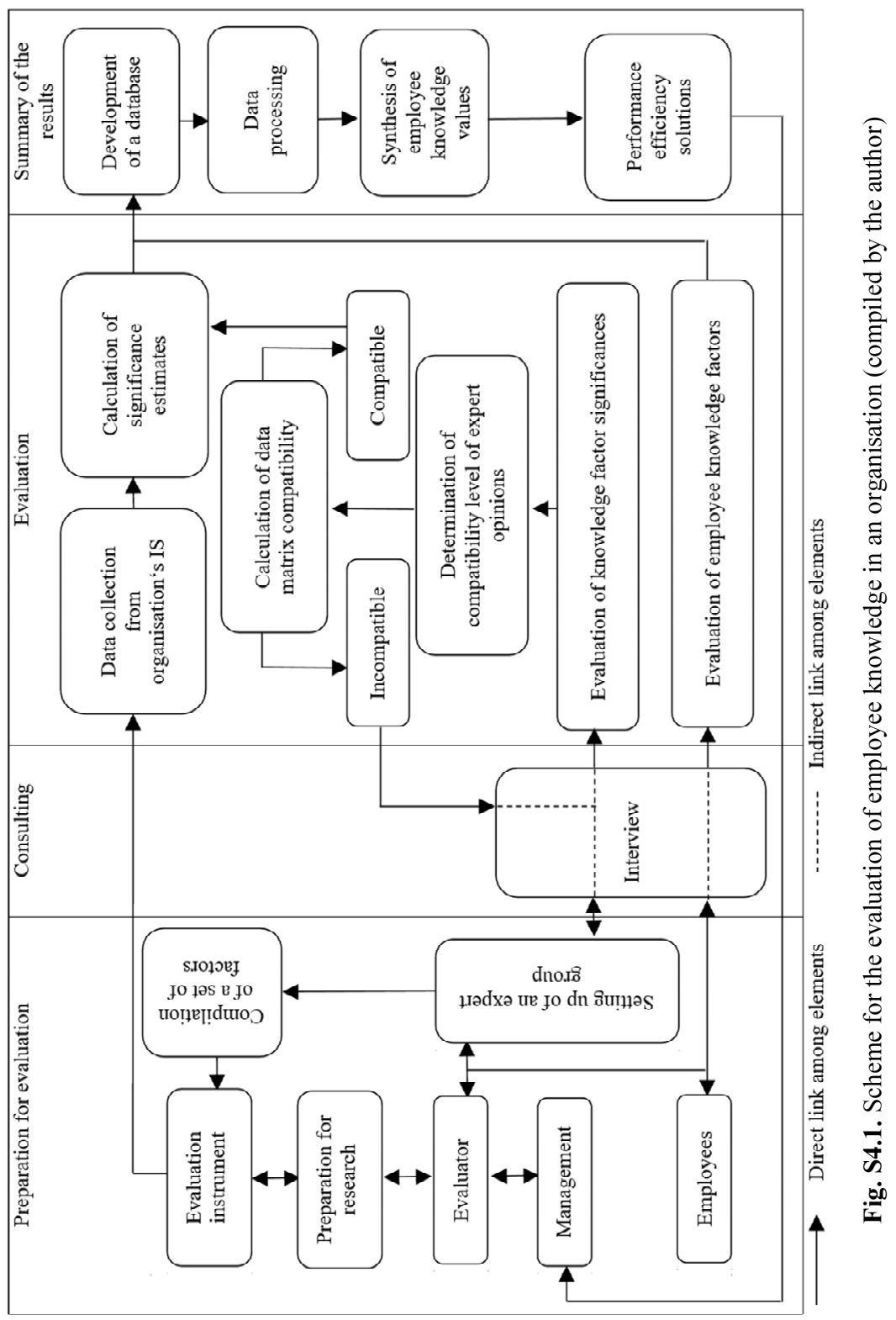


Five business organisations were selected for research. Two of them function in Lithuania, one - in Australia, and two - in Ireland. Two of the selected organisations (one in Lithuania and one in Ireland) meet the requirements of medium enterprises, i. e. companies with fewer than 250 employees, the financial results of which correspond to at least one of the following conditions: 1) annual income of a company does not exceed EUR 50 milion; 2) the value of the assets indicated in the balance sheet does not exceed EUR 43 milion. The company based in Australia and the other Lithuanian company meet the requirements of small enterprises, i. e. companies with fewer than 50 employees, the financial results of which correspond to at least one of the following conditions: 1) annual income of a company does not exceed EUR 10 milion; 2) the value of the assets indicated in the balance sheet does not exceed EUR 10 milion. The other Irish company meets the requirements of very small enterprises, i. e. companies with fewer than 10 employees, the financial results of which correspond to at least one of the following conditions: 1) annual income of a company does not exceed EUR 2 milion; 2) the value of the assets indicated in the balance sheet does not exceed EUR 2 milion.

The following three criteria were applied for the selection of experts: at least 5-year experience in work at management level, participation in at least two projects or work groups, and at least 10-year experience in the sphere of business. This way, the following nine experts from different business companies were selected: two experts from Australia, one expert from Ireland, one expert from Germany, five experts from Lithuania. The average work experience at management level -10.4 years, average work experience 16.5 years. Each expert participated on average in three projects or work groups.

Having applied the developed methodology and conducted the experiment in the organisations, the final estimates of organisation employee knowledge synergy according to the formula S1 were calculated (Table S4.2).

Table S4.2. Distribution of final estimate in organisations (compiled by the author)

\begin{tabular}{|l|c|c|c|}
\hline Estimates & $\begin{array}{l}\text { Employee } \\
\text { knowledge } \\
\text { estimates }\end{array}$ & $\begin{array}{l}\text { Estimates of } \\
\text { relations among } \\
\text { employees }\end{array}$ & $\begin{array}{l}\text { Summarising } \\
\text { estimate } S_{\check{z}}\end{array}$ \\
\hline VI X miškų urėdija & 343.17 & 341 & 100.64 \\
\hline UAB Skrema & 65.61 & 64 & 102.52 \\
\hline Geelong Garage Doors & 108.94 & 99 & 110.04 \\
\hline Kiverco & 416.07 & 583 & 71.37 \\
\hline Flowerbox & 45.34 & 36 & 125.94 \\
\hline
\end{tabular}

To summarize the received results, it can be stated that the synergy from knowledge sharing is greater in a small group with a small number of members (see Fig. S4.2). Nevertheless, with time, such a group can feel the lack of opinions and ideas. Therefore, constant improvement of qualification, new knowledge and continuous monitoring of the environment within an organisation (especially technological, social, competitive, etc.) are necessary. 


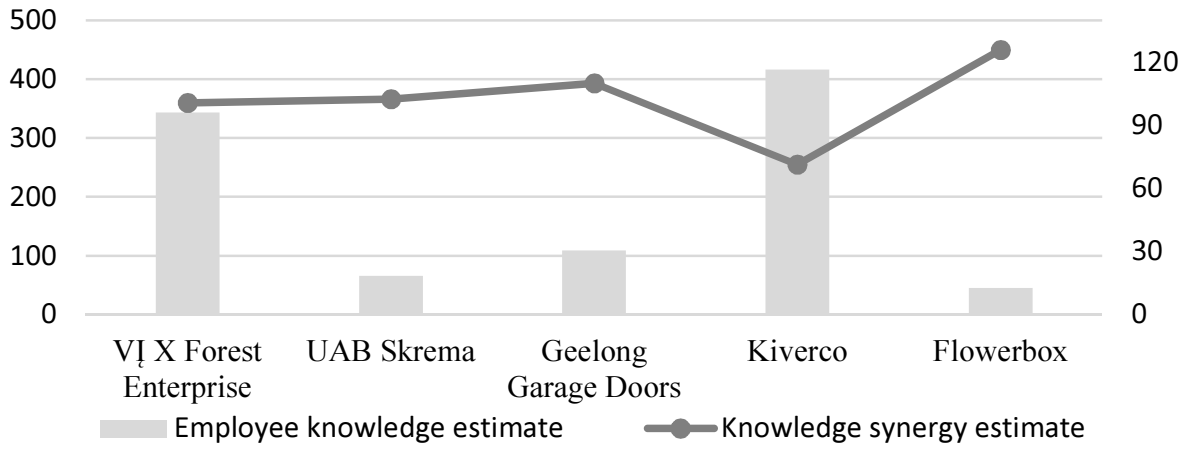

Fig. S4.2. Comparison of employee knowledge and knowledge synergy (compiled by the author)

Having conducted thorough organisation employee knowledge synergy research and reviewed the result of experimental studies, it would be appropriate to apply the proposed knowledge synergy building measures (Table S4.3).

Table S4.3. Knowledge synergy building measures (compiled by the author)

\begin{tabular}{|l|l|l|}
\hline $\begin{array}{l}\text { Stages of } \\
\text { knowledge } \\
\text { cycle }\end{array}$ & Measure & Justification of a measure \\
\hline $\begin{array}{l}\text { Knowledge } \\
\text { identification }\end{array}$ & $\begin{array}{l}\text { New knowledge } \\
\text { management/evalua } \\
\text { tion/strategy models }\end{array}$ & $\begin{array}{l}\text { Tacit knowledge will be identified more precisely and } \\
\text { will be presented in an understandable form. }\end{array}$ \\
\hline $\begin{array}{l}\text { Knowledge } \\
\text { creation }\end{array}$ & $\begin{array}{l}\text { Innovation creation } \\
\text { Learning through } \\
\text { work }\end{array}$ & $\begin{array}{l}\text { Explicit knowledge (tacit knowledge in particular) is } \\
\text { transferred from one employee to another. }\end{array}$ \\
\hline $\begin{array}{l}\text { Knowledge } \\
\text { storage }\end{array}$ & $\begin{array}{l}\text { Unconventional } \\
\text { learning methods }\end{array}$ & Stored knowledge becomes accessible to everybody. \\
\hline $\begin{array}{l}\text { Knowledge } \\
\text { dissemination }\end{array}$ & Open cooperation & $\begin{array}{l}\text { Knowledge is checked - false knowledge is rejected, } \\
\text { true knowledge is employed. }\end{array}$ \\
\hline
\end{tabular}

New knowledge management/evaluation/strategy models will lead to faster identification of employee knowledge, which will encourage the creation of new knowledge. Stored knowledge will be accessible to all employees in an organisation; therefore, the possibility of errors will be significantly reduced. Organisation employees will share knowledge actively and immdiately, thus creating a unique organisational environment and culture and will lead to knowledge synergy.

\section{General conclusions}

1. Scientists have been researching knowledge, its types in various spheres for several centuries. As the result, highly diverse knowledge content typical of a certain field has taken shape. Various terms (more of episodic nature) have been applied for the research 
of knowledge sphere; therefore, having analysed the concept of knowledge defined by various scientists, a new definition of knowledge was crystallised, i. e. knowledge is the expression of the process of a person's cognition, shaped by personal characteristics and the surroundings and enabling the person to act. The definition of knowledge synergy was crystallised, i. e. knowledge synergy is the interaction result of explicit and tacit knowledge that has an impact on the activities of an individual or a company and creates new knowledge. The proposed definitions of knowledge and knowledge synergy not only reveal the links between knowledge and knowledge synergy but also enable the identification of knowledge synergy components and development of knowledge synergy evaluation research.

2. In these times of accelerating change in technologies, the problem of knowledge dissemination and aging is highly relevant. When an employee is an active market member and transfers their knowledge to others, such knowledge becomes known to everyone, loses its value and uniqueness and ages with changing technologies. In all four knowledge management stages - identification, creation, storage, dissemination - the problem areas of knowledge leakage, devaluation, dependence and trust were determined. It is necessary for an organisation seeking to combine employee knowledge and apply it for the management of business processes, creation of value and effective use of knowledge synergy to pay attention to knowledge problem areas and systematically solve such problems during all knowledge management stages.

3. Following the conducted analysis of knowledge synergy evaluation methodological base, it can be concluded that the studies on knowledge synergy evaluation have been insufficient; moreover, the basic knowledge synergy evaluation components - employee knowledge and relations among employees - can be identified. The proposed fundamental knowledge synergy evaluation scheme as well as evaluation methodology based on these components leads to rational and objective knowledge synergy evaluation. The analysis of the methodological base of knowledge synergy component evaluation prompted the following suggestions:

3.1. It is appropriate to conduct employee knowledge evaluation by grouping the factors into the blocks of explicit and tacit knowledge, which enables comprehensive and objective evaluation of employee knowledge.

3.2. In order to rationally evaluate relations among employees, it is necessary to do the following: a) to identify the types of relations; b) to apply a method of effective relation evaluation with reference to the type of relations among employees, i. e. a method based on organisation structure analysis is applied for the calculation of personal and group relations, whereas a method based on management theory norms is applied for the calculation of separate relations among employees.

4. The methodology prepared for the evaluation and integration of organisation employee knowledge (divided into two blocks: explicit and tacit), the factors of such blocks and their components into a general estimate enables comprehensive evaluation and quantification of organisation employee knowledge. The set of multi-criteria evaluation methods (SAW, AHP) applied for employee knowledge evaluation enables the comparison and analysis of organisation employee knowledge from various perspectives, i. e. 1) the application of SAW method enables the integration of organisation employee knowledge factors into one summarising estimate; 2) the application of AHP method 
supplements the research, i. e. employee knowledge factors are structured and evaluated in a pairwise manner. Employee knowledge evaluation enables an organisation to determine the strengths and weaknesses of its employees, whereas the result of the summarising estimate enables comparative analysis with other organisations.

5. The carried out experiment confirmed that the prepared standardized methodology for the evaluation of organisation employee knowledge is flexible, i. e. can be applied in various organisations. High estimates of explicit knowledge block show that employees have sufficient education, use technologies at work, have vast professional experience at work, often improve their qualification in various courses and seminars, and believe their salary meets their work expectations. Low estimates of the same knowledge block reveal that the management should adopt decisions to improve factor results, i. e. review the education level of all employees and provide employees with the possibility to study, encourage employees to use technologies and look for solutions to improve their qualification. High estimates of tacit knowledge block show huge motivation to work, autonomy at work, employee initiative in realisation of organisational goals and a strong desire to implement them, the striving for good results by assuming the responsibility for own tasks, the ability to do complicated work in accordance with work culture. Low estimates of tacit knowledge block reveal that the management should adopt decisions to motivate employees, encourage the wish to seek better results, engage staff in joint activities through immediate communication among employees, and emphasize the importance of goal achievement as well as the value of initiative. In cases of average estimates in both knowledge blocks the management can choose to maintain status quo but it should constantly monitor the situation in an organisation, e.g. by organising surveys among employees. 



\section{Priedai $^{3}$}
A priedas. Šiuolaikinis žinių apibūdinimas
B priedas. Žiniu potencialo sandara
C priedas. Tinklo sampratos ịvairovè
D priedas. Žiniu vertinimo veiksniai
E priedas. Daugiakriterinių metodų klasifikacija
F priedas. Anketa ekspertams (SAW)
G priedas. Anketa ekspertams (AHP)
H priedas. Disertacijos autorès sąžiningumo deklaracija
I priedas. Bendraautorių sutikimai teikti publikacijų medžiagą disertacijoje

J priedas. Autorès mokslinių publikacijų disertacijos tema kopijos

${ }^{3}$ Priedai pateikiami pridedamoje kompaktineje plokštelèje. 
Aušra Katinienè

ORGANIZACIJOS DARBUOTOJŲ ŽINIŲ

SINERGIJOS VERTINIMAS

Daktaro disertacija

Socialiniai mokslai, vadyba (03S)

Aušra Katinienè

EVALUATION OF ORGANISATION

EMPLOYEE KNOWLEDGE SYNERGY

Doctoral Dissertation

Social Sciences,

Management (03S)

2018-04-30. 15 sp. I. Tiražas 20 egz.

Vilniaus Gedimino technikos universiteto

leidykla "Technika",

Saulètekio al. 11, 10223 Vilnius,

http://leidykla.vgtu.It

Spausdino Bl UAB „Baltijos kopija“

Kareivių g. 13B, 09109 Vilnius 